UNIVERSIDADE DE SÃO PAULO

FACULDADE DE ECONOMIA, ADMINISTRAÇÃO E CONTABILIDADE DEPARTAMENTO DE ADMINISTRAÇÃO PROGRAMA DE PÓS-GRADUAÇÃo EM ADMINISTRAÇÃo

ESCALA E VIABILIDADE DAS INSTITUIÇÕES FINANCEIRAS

Fernando Antonio Perrone Pinheiro

Orientador: Prof. Dr. José Roberto Ferreira Savoia

SÃo PAULO 
Prof. Dr. Marco Antonio Zago

Reitor da Universidade de São Paulo

Prof. Dr. Adalberto Américo Fischmann

Diretor da Faculdade de Economia, Administração e Contabilidade

Prof. Dr. Roberto Sbragia

Chefe do Departamento de Administração

Prof. Dr. Moacir de Miranda Oliveira Júnior Coordenador do Programa de Pós-Graduação em Administração 


\title{
ESCALA E VIABILIDADE DAS INSTITUIÇÕES FINANCEIRAS
}

\author{
Tese apresentada ao Programa de Pós- \\ Graduação em Administração do \\ Departamento de Administração da Faculdade \\ de Economia, Administração e Contabilidade \\ da Universidade de São Paulo como requisito \\ parcial para a obtenção do título de Doutor em \\ Ciências.
}

Orientador: Prof. Dr. José Roberto Ferreira Savoia

\section{Versão Corrigida}

(versão original disponível na Biblioteca da Faculdade de Economia, Administração e Contabilidade)

\section{SÃO PAULO}


Pinheiro, Fernando Antonio Perrone.

Escala e viabilidade das instituições financeiras / Fernando Antonio Perrone Pinheiro. - São Paulo, 2016.

$190 \mathrm{p}$.

Tese (Doutorado) - Universidade de São Paulo, 2016.

Orientador: José Roberto Ferreira Savóia.

1. Bancos 2. Regulação bancária 3. Capital mínimo 4.Instituições financeiras 5. Banco Central I. Universidade de São Paulo. Faculdade de Economia, Administração e Contabilidade II. Título.

CDD - 332.1 
À Lais, meu amor, sempre ao meu lado. 
Agradecimentos

Ao Professor Dr. José Roberto Ferreira Savoia, pela orientação, encorajamento e apoio ao longo do curso;

Ao Professor Dr. José Roberto Securato, pelo apoio na elaboração deste trabalho;

Aos demais professores da FEA USP, em especial aos professores doutores Cláudio Felisoni de Angelo, José Augusto Giesbrecht da Silveira, Nuno Manoel Martins Dias Fouto, Eduardo Kazuo Kayo, Joe Akira Yoshino, Francisco Anuatti, Maria Aparecida Gouvêa e Paulo Roberto Feldman, cujas disciplinas eu tive o privilégio de cursar.

Aos amigos, os professores doutores Eduardo Contani, Fabiana Lopes da Silva e Daniel Reed Bergmann, que proporcionaram uma interessante troca de conhecimentos;

Aos amigos de longa data, professores doutores Ricardo Humberto Rocha e José Carlos Luxo, que reencontrei no meio acadêmico;

Aos professores integrantes da banca;

Aos colegas do curso, pela amizade, respeito e prazer do convívio;

À equipe da FIA, em especial à Cristina Ananias;

Aos funcionários da FEA-USP, em especial àqueles da Seção de Pós-Graduação;

A todos os meus sinceros agradecimentos 


\section{RESUMO}

O mercado financeiro brasileiro é caracterizado pela elevada concentração bancária, onde os cinco maiores bancos detêm a maior parte dos ativos financeiros. Bancos pequenos e médios têm que disputar espaços com os grandes conglomerados financeiros. Questões como economia de escala e custo de observância às normas são essenciais para a sobrevivência destas instituições menores.

A aprovação para a constituição de instituições financeiras no País é dada pelo Banco Central do Brasil, que estabelece os valores de capital mínimo, em função da modalidade de instituição. Por sua vez, o Comitê de Supervisão Bancária de Basiléia estabelece os padrões máximos de alavancagem, o que indica qual volume de carteira pode ser contratado, dado este patrimônio.

Este trabalho tem como objetivo verificar se os valores de capital mínimo estabelecidos pelo Banco Central do Brasil são compatíveis com a estrutura de custo das instituições, e com o objetivo de retorno dos acionistas. Serão utilizados dados dos demonstrativos das instituições financeiras e, com base em modelo de regressão de dados em painel estático, será construída uma curva de retornos em função do porte da instituição. Este retorno, comparado com o custo de capital calculado pelo CAPM indicará a partir de que porte uma instituição financeira é viável.

Palavras chave: bancos, regulação bancária, capital mínimo, instituições financeiras, Banco Central. 


\begin{abstract}
The Brazilian financial market is characterized by its huge banking concentration, where the five largest banks hold most part of the assets. Small and medium size financial institutions have to compete with the larger financial conglomerates. Economy of scale and cost of compliance issues are essential for the survival of the smaller institutions.

The approval of a new financial institution is given by the Brazilian Central Bank, who establishes the minimum equity value, depending on the type of institution intended. Additionally, the Basle Committee on Banking Supervision fixes the maximum leverage standards, what indicates the maximum credit portfolio possible, given this equity value.

This thesis aims to verify if the minimum equity value established by the Brazilian Central Bank is compatible with the banks operational cost and the shareholder return objective. Data of the financial statements will be used in conjunction with static panel regressions, to construct the return curve regarding the dimension of the institution. This will be compared with the shareholder cost of capital, estimated by de CAPM, to indicate the minimum dimension, which makes feasible the institution.
\end{abstract}

Key words: banks, banking regulation, minimum capital, financial institutions, Central Bank. 


\section{SUMÁRIO}

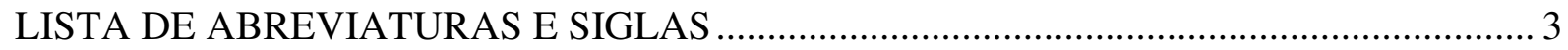

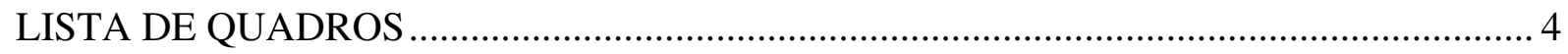

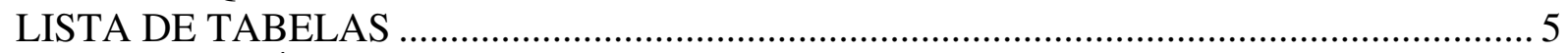

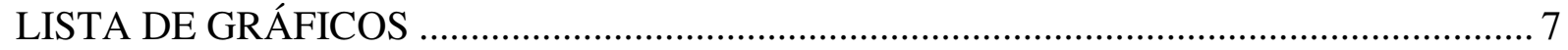

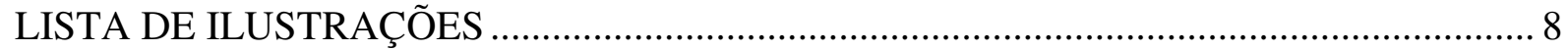

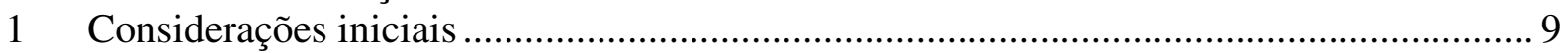

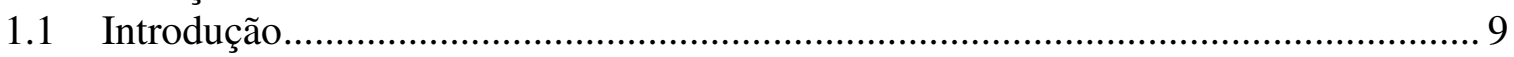

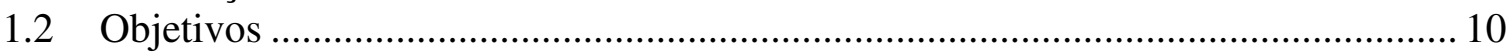

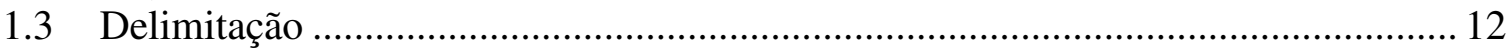

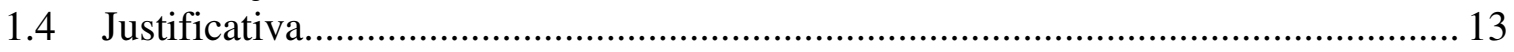

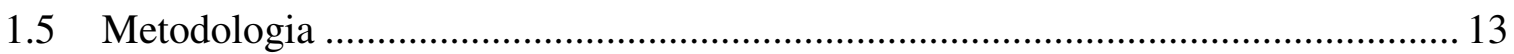

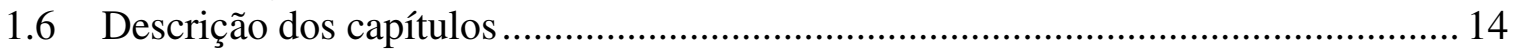

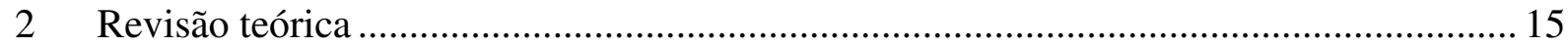

2.1 Capital regulatório e supervisão bancária ............................................................. 15

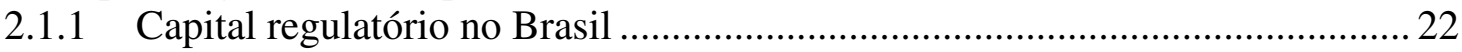

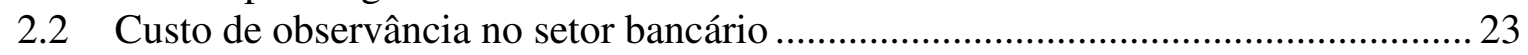

2.3 Eficiência bancária e economia de escala ............................................................... 27

2.4 O ambiente competitivo: podem as pequenas instituições sobreviver? ................... 32

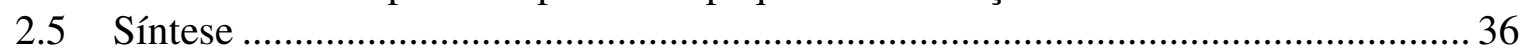

3 Participação de mercado e resultados das entidades do sfn ......................................... 38

3.1 Participação de mercado dos consolidados do SFN ............................................... 38

3.2 Retorno sobre o patrimônio líquido dos consolidados do SFN ................................. 41

3.3 Instituições financeiras constituídas em passado recente .......................................... 44

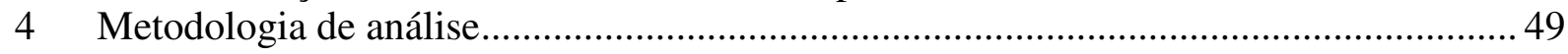

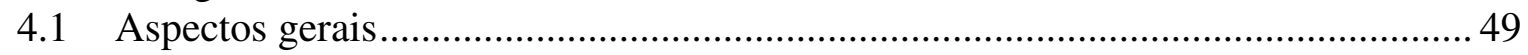

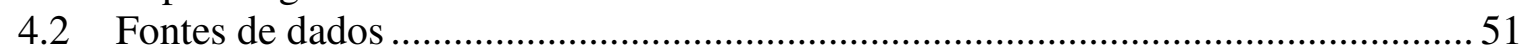

4.3 Instituições financeiras integrantes da amostra ................................................. 51

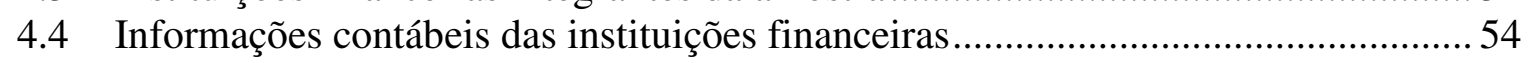

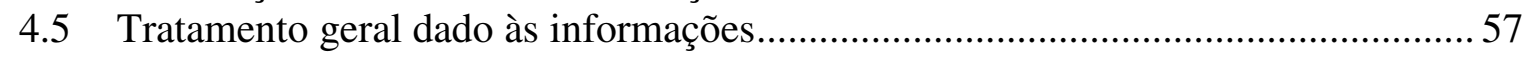

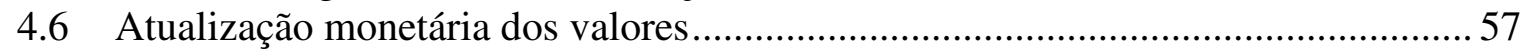

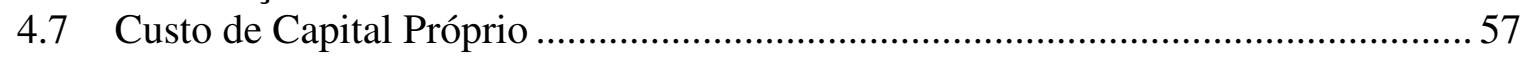

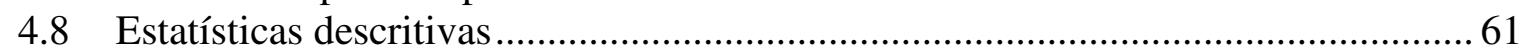

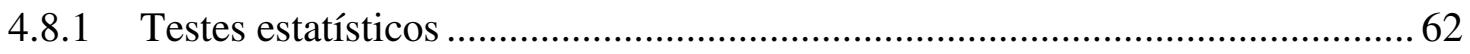

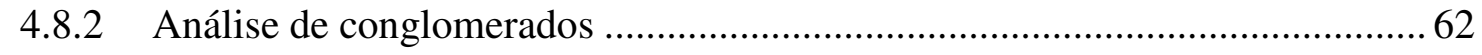

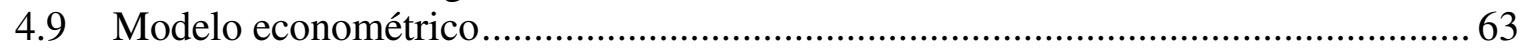

4.9.1 Regressões explicativas do retorno sobre o patrimônio líquido.......................63

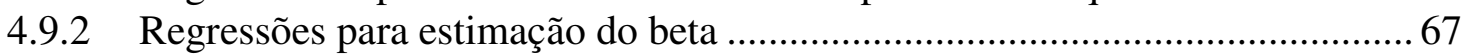

4.9.3 Valor do patrimônio líquido mínimo das instituições ......................................... 68

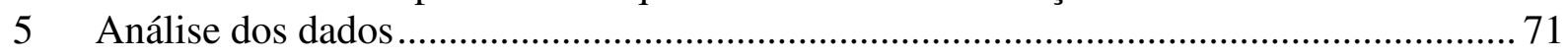

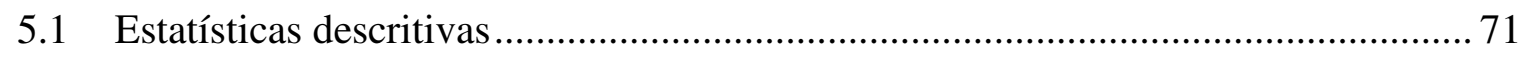

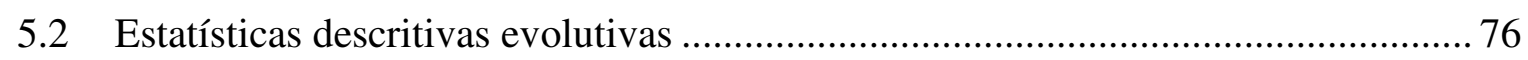

5.3 Estatística descritiva com clusters definidos pelo patrimônio líquido...................... 78

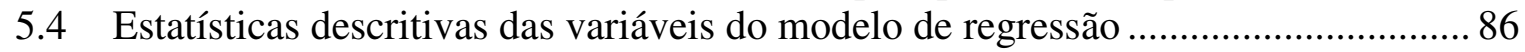

5.4.1 Exclusão das instituições com retornos extremos ........................................ 88

5.5 Correlação entre o ROE e o porte da instituição ……................................................ 92

5.5.1 Bancos comerciais ou múltiplos com carteira comercial ............................... 92

5.5.2 Bancos de investimento ou múltiplos com carteira de investimento ................96

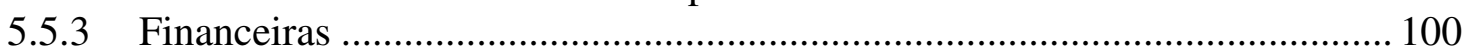




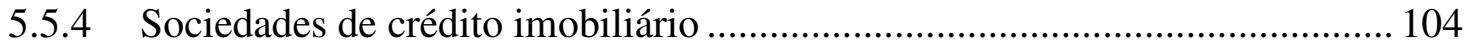

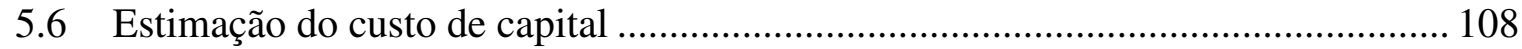

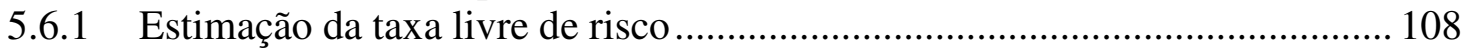

5.6.2 Estimação do prêmio de risco de mercado ....................................................... 111

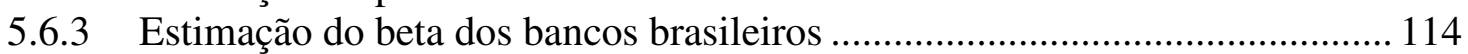

5.6.4 Estimação do beta do IBOVESPA com relação ao S\&P500 ......................... 117

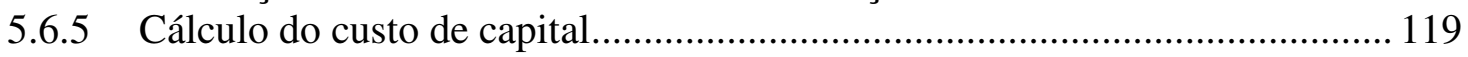

5.7 Estimativa do porte mínimo das instituições financeiras ...................................... 120

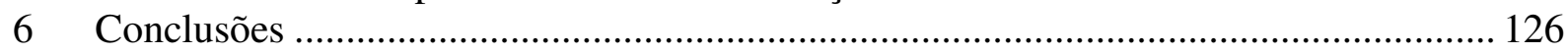

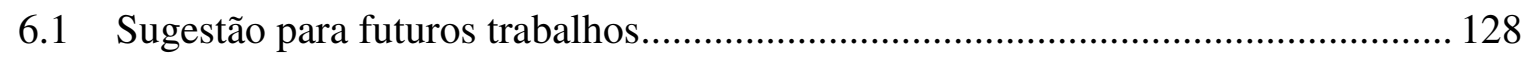

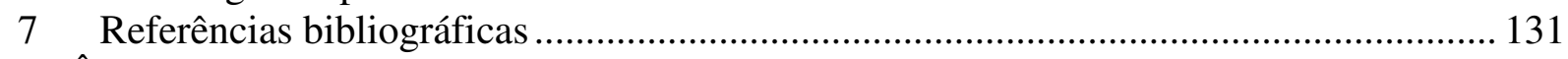

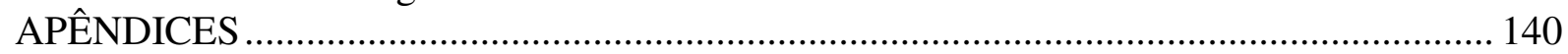




\section{LISTA DE ABREVIATURAS E SIGLAS}

APR: Ativos ponderados pelo risco

BACEN: Banco Central do Brasil

BCBS: Basle Committee on Banking Supervision

BIS: Bank for International Settlements

CAPM: Capital Asset Price Model

CMN: Conselho Monetário Nacional

COSIF: Plano Contábil das Instituições do Sistema Financeiro Nacional

EEP: Expected Equity Premium

ERP: Equity risk premium

HEP: Historical Equity Premium

IAPM: International Asset Pricing Model

IPEA: Instituto de Pesquisas Econômicas Avançadas

LTN: Letra do Tesouro Nacional

MQO: Mínimos Quadrados Ordinários

OBS: Off-balance-sheet instruments

PROER: Programa de Estímulo à Reestruturação e ao Fortalecimento do Sistema

Financeiro Nacional

PROES: Programa de Incentivo à Redução do Setor Público Estadual na Atividade Bancária

RAROC: Risk ajusted return on capital

REP: Required Equity Premium

ROE: Return on equity

RWA: Risk weighted assets

SELIC: Sistema Especial de Liquidação e Custódia

SFN: Sistema Financeiro Nacional 


\section{LISTA DE QUADROS}

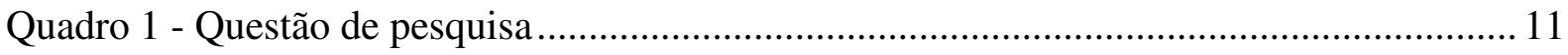

Quadro 2 - Valores mínimos de capital por modalidade de instituição financeira .................. 22

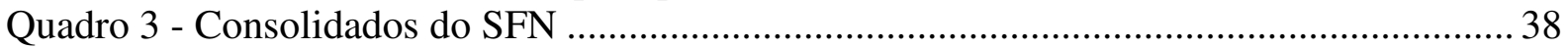

Quadro 4 - Bancos constituídos em passado recente ........................................................... 45

Quadro 5 - Lista de fontes de informação e dados ....................................................................51

Quadro 6 - Estrutura do relatório Top 50 do BACEN …….......................................................54

Quadro 7 - Variáveis para o cálculo do custo de capital próprio $\left(\mathrm{K}_{\mathrm{E}}\right)$....................................59

Quadro 8 - Regressão que irá responder à questão de pesquisa............................................ 65 


\section{LISTA DE TABELAS}

Tabela 1- Retorno sobre o patrimônio líquido dos bancos no Brasil ...................................... 36

Tabela 2 - Participação de mercado dos Consolidados Bancários ............................................ 41

Tabela 3 - Retorno sobre o patrimônio dos consolidados do SFN - dez/2014 ....................... 42

Tabela 4 - Evolução do retorno sobre o patrimônio do SFN ….............................................. 42

Tabela 5 - Evolução das autorizações para funcionamento concedidas................................... 44

Tabela 6 - Patrimônio líquido de bancos constituídos entre 2005 e 2009............................... 45

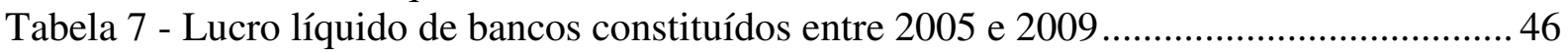

Tabela 8 - Retorno sobre o patrimônio de bancos constituídos entre 2005 e 2009.................. 46

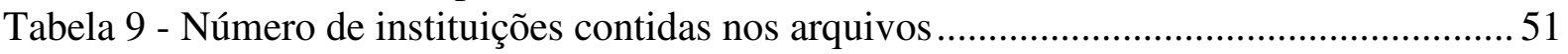

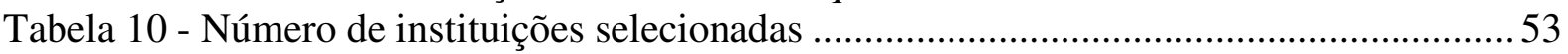

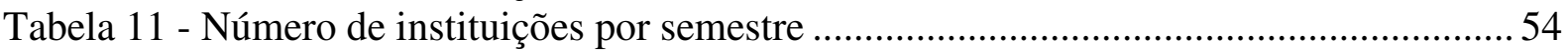

Tabela 12 - Estatísticas descritivas: ativo total e patrimônio líquido....................................... 72

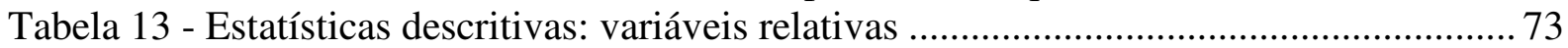

Tabela 14 - Teste Kolmogorov-Smirnov para normalidade: variáveis relativas ..................... 74

Tabela 15 - Teste de Kruscal Wallis para igualdade de médias: variáveis relativas................. 74

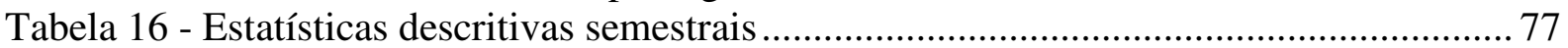

Tabela 17 - Teste de Kruscal Wallis para igualdade de médias - médias temporais................ 78

Tabela 18 - Análise de conglomerados: coeficientes de proximidade por estágio ...................79

Tabela 19 - Análise de conglomerados: centróides do método de K-Médias ............................ 80

Tabela 20 - Média das principais variáveis relativas, de acordo com o porte da instituição ... 81

Tabela 21 - Teste de Kruscal Wallis para igualdade de médias: variáveis agrupadas por

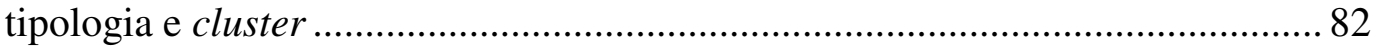

Tabela 22 - Teste de Kruscal Wallis para a igualdade de médias: variáveis agrupadas por

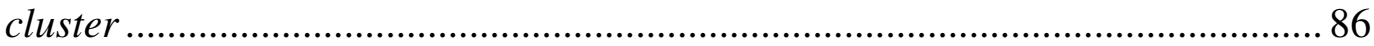

Tabela 23 - Estatísticas descritivas: ROE e alavancagem bancária ....................................... 87

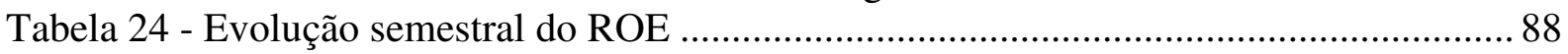

Tabela 25 - Teste de Kruscal Walis para igualdade de médias: ROE agrupado por semestre. 88

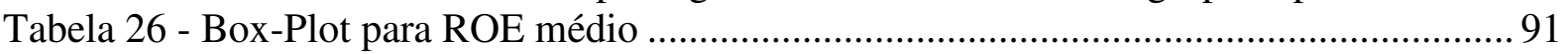

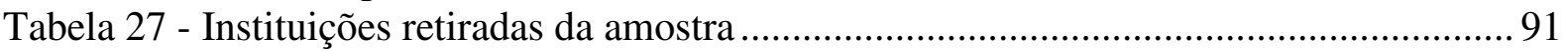

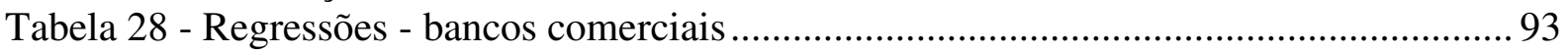

Tabela 29 - Regressões reprocessadas - bancos comerciais ................................................. 94

Tabela 30 - Teste de média condicional zero dos resíduos - bancos comerciais ..................... 95

Tabela 31 - Teste de Shapiro-Francia: resíduos - bancos comerciais.................................... 95

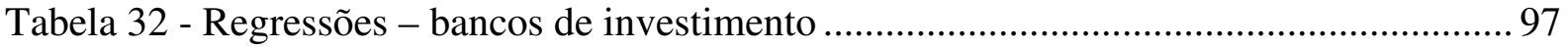

Tabela 33 - Regressões reprocessadas - bancos de investimento ......................................... 98

Tabela 34 - Teste de média condicional zero dos resíduos - bancos de investimento ............ 99

Tabela 35 - Teste de Shapiro-Francia: resíduos - bancos de investimento ............................ 99

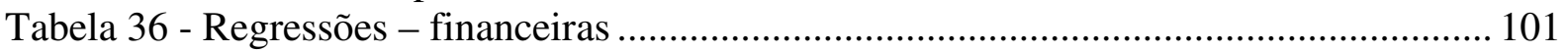

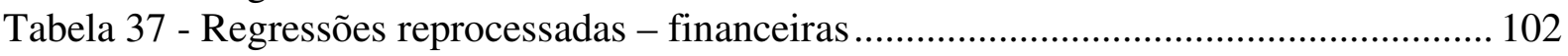

Tabela 38 - Teste de média condicional zero dos resíduos - financeiras .............................. 103

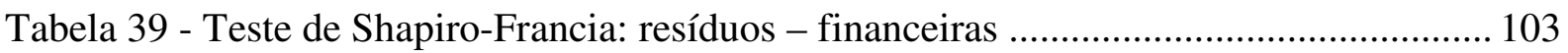

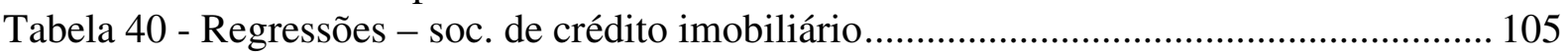

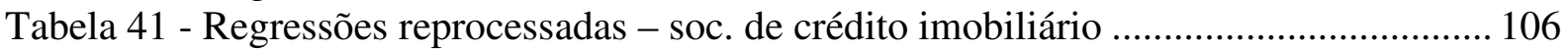

Tabela 42 - Teste de média condicional zero dos resíduos - soc. de crédito imobiliário ....... 107

Tabela 43 - Teste de Shapiro-Francia: resíduos - soc. de crédito imobiliário ......................... 107

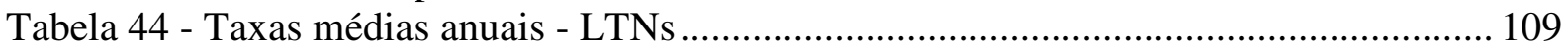

Tabela 45 - Taxas médias anuais dos títulos do Tesouro Americano ................................... 110 
Tabela 46 - Prêmio de risco de mercado segundo Fernandez ............................................... 112

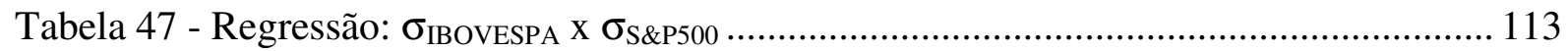

Tabela 48 - Prêmio de risco de mercado segundo Damodaran ............................................. 113

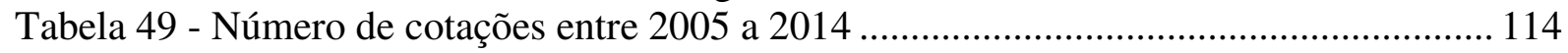

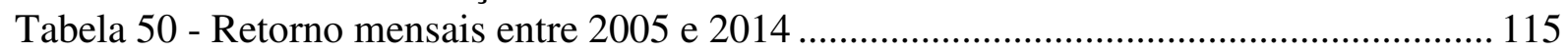

Tabela 51 - Regressão para estimação do beta dos bancos ................................................... 115

Tabela 52 - Regressão reprocessada para estimação do beta .............................................. 116

Tabela 53 - Teste de média condiciona zero dos resíduos - beta dos bancos brasileiros ...... 116

Tabela 54 - Teste de normalidade dos resíduos - beta dos bancos brasileiros ....................... 117

Tabela 55 - Regressão para estimação do beta do IBOVESPA …........................................ 118

Tabela 56 - Teste de média condiciona zero dos resíduos - beta Ibovespa / S\&P500 .......... 119

Tabela 57 - Teste de normalidade dos resíduos - beta Ibovespa / S\&P500.......................... 119

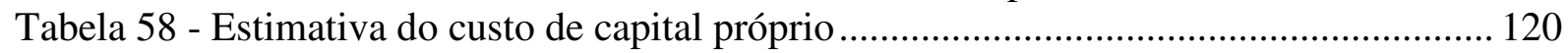

Tabela 59 - Resultado com significância das regressões ...................................................... 121

Tabela 60 - Valor do Patrimônio Líquido Mínimo, em função do cenário............................. 124

Tabela 61 - Valores Mínimos de Patrimônio Líquido estabelecidos pelo BACEN................ 124

Tabela 62 - Valor do Patrimônio Líquido Mínimo, em função do custo de capital................ 125 


\section{LISTA DE GRÁFICOS}

Gráfico 1 - Participação no Ativo Total do SFN........................................................................ 39

Gráfico 2 - Participação nas Operações de Crédito e de Arrendamento do SFN...................... 39

Gráfico 3 - Participação nos Depósitos Totais do SFN ............................................................ 40

Gráfico 4 - Participação no resultado operacional do SFN ...................................................... 40

Gráfico 5 - Evolução do retorno sobre o patrimônio do SFN ................................................... 43

Gráfico 6 - Bancos recém-constituídos: ROE x Patrimônio Líquido......................................... 47

Gráfico 7 - Análise de conglomerados: coeficientes de proximidade em número índice........ 79

Gráfico 8 - Análise de conglomerados: variação percentual dos coeficientes de

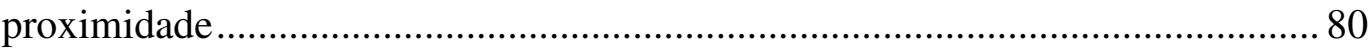

Gráfico 9 - Influência do tamanho na relação entre o imobilizado e o patrimônio líquido ..... 83

Gráfico 10 - Influência do tamanho na relação entre a despesa administrativa e o

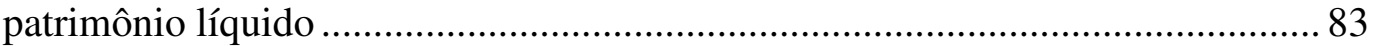

Gráfico 11 - Influência do tamanho na proporção de receitas com serviços no resultado........ 84

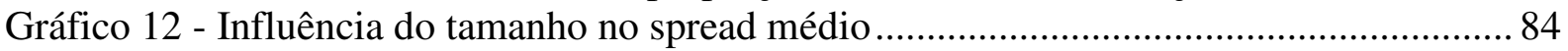

Gráfico 13 - Influência do tamanho na taxa média de aplicação .............................................. 85

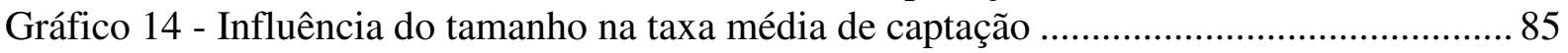

Gráfico 15 - ROE médio 2010 a 2014: bancos comerciais ..................................................... 89

Gráfico 16 - ROE médio 2010 a 2014: bancos de investimento .............................................. 90

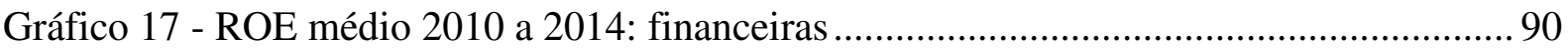

Gráfico 18 - ROE médio 2010 a 2014: sociedades de crédito imobiliário ............................. 91

Gráfico 19 - Histograma dos resíduos - bancos comerciais ................................................. 95

Gráfico 20 - Histograma dos resíduos - bancos de investimento ...........................................99

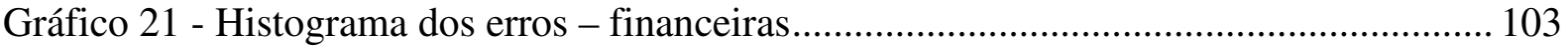

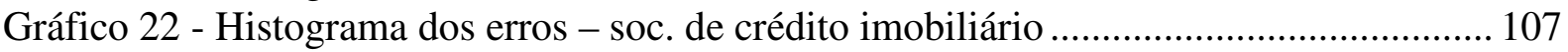

Gráfico 23 - Estrutura a termo de taxas de LTNs .................................................................. 109

Gráfico 24 - Estrutura a termo de taxas de títulos do Tesouro Americano .............................. 110

Gráfico 25 - Histograma de frequência dos resíduos - beta dos bancos brasileiros ............... 117

Gráfico 26 - Retorno do IBOVESPA x Retorno do S\&P500 ................................................. 118

Gráfico 27 - Bancos comerciais: curva de retorno x patrimônio líquido ................................ 121

Gráfico 28 - Bancos de investimento: curva de retorno x patrimônio líquido ......................... 122

Gráfico 29 - Financeiras: curva de retorno x patrimônio líquido.......................................... 122

Gráfico 30 - Sociedades de crédito imobiliário: curva de retorno x patrimônio líquido ........ 123 


\section{LISTA DE ILUSTRAÇÕES}

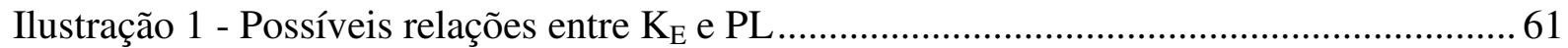

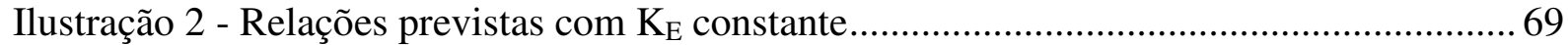

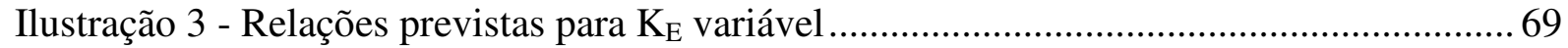

Ilustração 4 - Relações previstas para $\mathrm{K}_{\mathrm{E}}$ variável e para diferentes níveis de alavanc .......... 70 


\section{CONSIDERAÇÕES INICIAIS}

\subsection{Introdução}

Segundo o dito popular, o segundo melhor negócio do Brasil é um banco mal administrado. Este sentimento decorre da capacidade do setor em produzir retornos consistentes ao longo da história econômica brasileira. Em tempos de inflação elevada, bancos eram excepcionalmente rentáveis, dado o float de inúmeros serviços, como a arrecadação de tributos, cobrança, pagamentos, e outros. Era o tempo da chamada ciranda financeira, em que parte significante do capital das empresas era aplicada em ativos financeiros. Afinal, nenhuma atividade produtiva era capaz de produzir ganhos entre $1 \%$ e $2 \%$ ao dia. As receitas com recursos em contas transitórias eram tão elevadas que levou o Banco Central do Brasil - BACEN - a dar a esses recursos tratamento semelhante àquele dispensado ao depósito à vista, e eles passaram a integrar a base de cálculo do depósito compulsório.

Com a estabilização da economia proporcionada pelo Plano Real várias instituições desapareceram, pois suas estruturas não podiam subsistir em um ambiente de baixa inflação em que a receita com floats tornava-se exígua. O BACEN, prudentemente, lançou o Programa de Estímulo à Reestruturação e ao Fortalecimento do Sistema Financeiro Nacional - PROER, e o Programa de Incentivo à Redução do Setor Público Estadual na Atividade Bancária PROES, programas esses que reestruturaram os bancos privados e públicos, respectivamente. Com a quase extinção das receitas com recursos em trânsito, os bancos no Brasil redescobriram sua principal missão, que é a de conceder crédito. Naturalmente o risco das instituições cresceu, mas as medidas prudenciais que se sucederam mantiveram o sistema saudável.

Muitos grupos econômicos viram a oportunidade de constituir instituições financeiras ao longo dos anos, seja para financiar sua cadeia de negócios, como clientes e fornecedores; ou como forma de diversificar as fontes de resultado, dado um universo de clientes que lhes era cativo. Bancos também foram criados lastreados na experiência de seus executivos na administração de negócios financeiros e na sua capacidade de comunicar credibilidade ao mercado. Filiais de bancos estrangeiros foram criadas para fomentar os negócios de empresas 
originárias naquele país, ou simplesmente para aproveitar as oportunidades do mercado brasileiro, campo fértil para a obtenção de retornos com a intermediação financeira, quando se considera o elevado spread bancário que é aqui praticado.

O BACEN estabeleceu uma série de requisitos para aprovar a criação de instituições financeiras, como: a reputação dos acionistas e suas experiências prévia na condução de negócios financeiros, a capacidade financeira do grupo de controle, a capacitação dos administradores, a elaboração de um plano de negócios que enuncie a viabilidade do empreendimento, os padrões de governança corporativa, a comprovação da origem dos recursos destinados à integralização do capital, e outros. Finalmente, o BACEN estabeleceu uma política de capital mínimo, que deve ser respeitado ao longo da vida da instituição. Os valores estabelecidos são específicos da modalidade de instituição que se pretende criar. A título de exemplo, um banco múltiplo requerer mais capital do que uma financeira.

Os valores de capital mínimo não estão relacionado aos padrões de capital regulatório estabelecidos pelo Comitê de Supervisão Bancária de Basiléia - BCBS, cujo objetivo é o estabelecimento de limites de alavancagem para os bancos; mas sua definição pelo BACEN visa restringir o número de instituições e só aprovar aquelas que tenham uma massa crítica.

O principal objeto desta tese consiste na avaliação destes valores mínimos, baseado na crença de que a defasagem da norma que o estabeleceu permite a constituição de instituições cuja reduzida escala de operações as torna incapazes de proporcionar retornos que atendam a expectativa de seus acionistas.

\subsection{Objetivos}

A constituição de instituições financeiras no País requer que sejam observados os parâmetros mínimos de capital estabelecidos pela Resolução CMN n 2.607/1999. Estes parâmetros são estabelecidos em função do tipo de instituição financeira, que se pretende constituir, a saber: banco comercial, banco de investimento, banco múltiplo, sociedade de crédito financiamento e investimento, de arrendamento mercantil, de crédito imobiliário, etc. O valor mínimo de capital deve ser observados durante toda a vida da instituição. 
Por sua vez, o capital integralizado possibilita a instituição alavancar para a contratação de uma determinada carteira de ativos financeiros, dentro dos limites de alavancagem estabelecidos pelo próprio BACEN. Como ativos financeiros entenda-se: empréstimos, financiamentos e títulos de dívida. Esta carteira de ativos produz retornos que devem ser suficientes para sustentar a estrutura de custos da instituição, bem como proporcionar ao acionista um retorno condizente com o risco assumido no negócio.

A preocupação com o retorno do acionista deve se fazer presente junto à autoridade monetária, pois instituições incapazes de remunerar o investidor dentro de suas expectativas de retorno serão incapazes de atrair novos capitais, no caso de surgimento de situações que venham a requerer a realização de aportes adicionais.

No tocante aos custos, as instituições financeiras são obrigadas a manter uma estrutura excessivamente onerosa, seja pela complexidade do negócio, com maciços investimentos em tecnologia da informação, ou seja pela estrutura de controles que o BACEN as obriga manter. A este último dá-se o nome de custo de observância. Esta estrutura de custos pode fazer com que a escala de operações precise ser maior do que aquela facultada pelo valor mínimo de capital estabelecido pelo BACEN.

Desta forma, os valores mínimos de capital definidos pelo BACEN podem resultar em instituições pequenas demais, com ativos insuficientes para fazer frente ao custo da estrutura, ao custo de observância, e incapazes de remunerar o acionista dentro de suas expectativas. Com base neste racional, a questão de pesquisa desta tese consiste em verificar se os valores mínimos de capital definidos são adequados.

A questão de pesquisa, a hipótese e o resultado esperado são apresentados no Quadro 1.

Quadro 1 - Questão de pesquisa

\begin{tabular}{|c|c|c|c|}
\hline Problema de pesquisa & Objetivo & Hipótese de pesquisa & Resultados esperados \\
\hline $\begin{array}{l}\text { A economia de escala das } \\
\text { instituições com capital } \\
\text { igual ao valor mínimo } \\
\text { estabelecido pelo Banco } \\
\text { Central do Brasil permite } \\
\text { à companhia arcar com } \\
\text { sua estrutura de custos e } \\
\text { remunerar adequada- } \\
\text { mente o acionista? }\end{array}$ & $\begin{array}{l}\text { Verificar se a norma } \\
\text { relativa ao valor mínimo } \\
\text { de capital é adequada e } \\
\text { sugerir sua revisão, se } \\
\text { necessário. }\end{array}$ & $\begin{array}{l}\text { H1: A norma não é } \\
\text { adequada e necessita de } \\
\text { revisão. }\end{array}$ & $\begin{array}{l}\text { As instituições financei- } \\
\text { ras devem ter um porte } \\
\text { maior do que aquele } \\
\text { estabelecido pela Re- } \\
\text { solução } \mathrm{n}^{\circ} 2.607 / 99 \text { com } \\
\text { vistas à economia de } \\
\text { escala. }\end{array}$ \\
\hline
\end{tabular}




\subsection{Delimitação}

A delimitação da pesquisa visa estabelecer limites para a investigação, em função da extensão do assunto ou pela impossibilidade de abranger todas as formas, variáveis ou condições que interagem com o objeto de pesquisa. Ander-Egg (1978, apud MARCONI; LAKATOS, 2005, p. 164-165) apresentam três níveis sobre os quais a delimitação é aplicada: quanto ao objeto, pela escolha de um maior ou menor número de variáveis de estudo; quanto ao campo de investigação, pela definição de um limite temporal ou de espaço geográfico; e quanto ao nível de investigação, englobando os estágios exploratórios, de investigação e de comprovação de hipóteses. Este trabalho requer que sejam estabelecidos delimitadores sobre estes três níveis:

a) Quanto ao objeto:

O presente trabalho não pretende discutir as questões de capital regulatório, isto é, os padrões de alavancagem bancária. Estes são, na verdade, condições de contorno para o problema.

Tão pouco se pretende discutir se o mencionado custo de observância é adequado ou não.

As instituições objeto deste trabalho são os bancos, as sociedades de crédito financiamento e investimento, as sociedades de crédito imobiliário e as sociedades de arrendamento mercantil. Não fazem parte do objeto de estudo desta tese as cooperativas de crédito, as distribuidoras de títulos e valores mobiliários (T.V.M.), as corretoras de câmbio e de T.V.M., as agências de fomento ou desenvolvimento, as associações de poupança e empréstimo, as sociedades de crédito ao microempreendedor, as companhias hipotecárias e as sociedades repassadoras de crédito imobiliário. Estas empresas deverão ser objeto de futuros estudos.

b) Quanto ao campo de investigação:

O estudo proposto irá se limitar a instituições financeiras no Brasil e os dados utilizados referem-se ao período compreendido entre 2010 e 2014, inclusive, e aos limites que vigoraram nesses anos. O uso de suas conclusões, para datas futuras, necessita de ajustes em função da inflação que incide sobre a estrutura de custos. Da mesma forma, se o BACEN vier a ajustar os valores mínimos de capital, a questão de pesquisa deve ser revisitada. 
c) Quanto ao nível de investigação:

Não existem estágios exploratórios, visto que a investigação irá se basear em dados secundários das demonstrações financeiras das instituições financeiras e em dados relacionados ao mercado de capitais.

A investigação não irá considerar o perfil da instituição quando ao seu mercado alvo e ao diferente risco que seu segmento de atuação pode significar. Isto decorre do fato de que muitas instituições atuam em mais de um segmento de mercado.

\section{$1.4 \quad$ Justificativa}

A norma em vigor sobre o valor mínimo do patrimônio líquido das instituições financeiras deve considerar parâmetros que garantam a sustentação do referido negócio, considerando uma estrutura de custos mínima, os custos de captação envolvidos, a composição das fontes de receitas, o nível de imobilizado e o retorno almejado pelo acionista. Se os valores mínimos de capital forem insuficientes, a autoridade de supervisão estará aprovando a constituição de novas instituições que não se sustentem, ou que venham a impor limites de custeio que restrinjam à contratação da estrutura necessária, dentre elas a de pessoas, o que pode elevar os riscos operacionais. Logo, este trabalho se justifica pela sugestão que se pretende dar aos grupos empreendedores que desejem constituir uma instituição financeira no Brasil, e ao próprio Banco Central do Brasil no sentido de promover a atualização da norma, com o intuito de apenas permitir a constituição de instituições que não venham a se constituir em problema no futuro.

\subsection{Metodologia}

Esta tese baseia-se em dados secundários, obtidos junto ao BACEN. Não se realizou, portanto, pesquisa de campo, dada a natureza do trabalho.

As respostas às questões secundárias de pesquisa serão obtidas por meios econométricos, regredindo-se o retorno sobre o patrimônio pela variável representativa do porte da 
instituição, isto é, seu patrimônio líquido.

A resposta à questão principal de pesquisa irá se basear na identificação do tamanho da instituição financeira a partir do qual é possível proporcionar retorno ao acionista igual ou superior ao custo de capital próprio, estabelecido pelo Capital Asset Price Model - CAPM, de Sharpe (1964).

O modelo de regressão adotado será o de dados em painel estático, agrupados pelo mês e ano do balanço, e pela instituição.

\subsection{Descrição dos capítulos}

Este trabalho está dividido em seis capítulos, incluído o primeiro, destinado às considerações iniciais. O segundo capítulo é dedicado à revisão teórica da literatura que tangencia o problema, como artigos sobre a alavancagem bancária, sobre a eficiência das instituições, sobre o custo de observância, dentre outros; também serão visitadas as normas do capital regulatório das instituições e outras que se relacionem ao objeto de estudo. O terceiro capítulo é destinado à apresentação das estatísticas do setor bancário brasileiro sob a ótica de sua rentabilidade e dos dados que irão responder às questões de pesquisa. No quarto capítulo é apresentada a metodologia utilizada no tratamento dos dados. No quinto capítulo é realizada a análise dos dados e respondida a questão de pesquisa. No sexto capítulo são apresentadas as conclusões. 


\section{REVISÃO TEÓRICA}

Esta revisão teórica irá abordar aspectos que tangenciam o problema de pesquisa principal, que gira em torno da viabilidade das instituições financeiras. Desta forma, este capítulo está dividido em seções segundo o tema abordado. A primeira seção diz respeito ao capital regulatório dos bancos e dos estudos que trataram dos efeitos destas regras sobre o mercado. A segunda discorre sobre os custos de observância e, uma vez que o ambiente regulatório impõe às instituições financeiras a manutenção de elevados padrões de governança corporativa, este aspecto também foi incluído. Na terceira seção são abordadas as questões de eficiência bancária e economia de escala, temas estes relevantes quando se discute a viabilidade das instituições financeiras de menor porte. A quarta seção trata do ambiente competitivo, onde pequenas instituições são obrigadas a disputar mercado com grandes conglomerados financeiros. Finalmente, na quinta seção procurou-se sintetizar as seções anteriores.

\subsection{Capital regulatório e supervisão bancária}

A viabilidade das instituições financeiras decorre, dentre outros fatores, do retorno proporcionado pelos ativos detidos pela instituição. Desta forma, faz-se necessário rever os aspectos relativos ao capital regulatório, que limitam o valor das carteiras de ativos.

Os bancos são depositários da poupança das famílias, das empresas e dos investidores institucionais. Eles exercem a função de intermediadores entre investidores e tomadores de recursos; portanto, têm um papel fundamental no desenvolvimento econômico das nações. Talvez por isso, Stiglitz e Weiss (1981) tenham afirmado que falência de um banco se constitua em um problema sistêmico.

Bancos podem inadimplir na hipótese de seus ativos - títulos, empréstimos e financiamentos - registrarem perdas superiores ao capital próprio da instituição. Por estas razões, a missão dos bancos centrais não se restringe às questões de política monetária e cambial, mas também a manutenção da estabilidade dos sistemas financeiros. Para isto, os bancos centrais dispendem especial atenção às normas de cunho prudencial. 
Dada a interconectividade dos mercados, as crises financeiras podem não se restringir a apenas um país, o que faz com que a regulação dos sistemas financeiros deva ser global. A entidade responsável por interagir com os bancos centrais com vistas ao estabelecimento de um padrão regulatório é o Bank for International Settlements - BIS. O banco foi criado em 1930 no âmbito do Young Plan com a função de coletar, administrar e distribuir os fundos provenientes das reparações da Primeira Guerra que haviam sido impostas à Alemanha pelo tratado de Versalhes. A necessidade de um órgão regulador internacional tornou-se evidente nos anos 70, com o final do acordo de Breton Woods, fato esse que acarretou considerável aumento do risco das exposições em moeda estrangeira e resultou na falência do Bankhaus Herstatt's na Alemanha e do Franklin National Bank of New York nos EUA (BCBS, 2014). Desta forma, o BIS passou a dedicar-se às questões relativas à estabilidade financeira internacional e, com esse propósito, criou o Comitê de Supervisão Bancária de Basiléia, ou Basle Comittee on Banking Supervision - BCBS (BCBS, 2014).

Em 1988 o BCBS publicou documento intitulado International Convergence of Capital Measurement and Capital Standards, conhecido no Brasil com Acordo de Capital de 1988, com o objetivo criar exigências mínimas de capital para instituições financeiras como forma de fazer face ao risco de crédito (BCBS, 1988). O princípio era que os bancos devem ter capital suficiente para suas perdas imprevistas de crédito. O Acordo de 1988 baseava-se nos seguintes parâmetros:

- O conceito de Ativos Ponderados pelo Risco, ou APR, cujo somatório multiplicado por um fator de risco de $8 \%$, definia o capital regulatório da instituição.

- Os conceitos de Capital Nível 1 e Capital Nível 2, ou respectivamente TIER 1 e TIER 2, na denominação do BCBS, que consiste no capital disponível para suportar as perdas. A tradução de TIER é camada; assim, o BCBS previu duas camadas de capital.

De modo geral, os fatores de ponderação de risco estabelecidos foram: 0\%, para caixa e títulos do governo federal ou do banco central local, emitidos na moeda nacional; 10\%, 20 ou 50\% para dívida pública, exceto a do governo central, a critério dos bancos centrais; $20 \%$ para valores em compensação, títulos de bancos de países do OECD e outros; 50\% para ativos interbancários e dívidas garantidas por hipotecas; e 100\% para os demais ativos, como empréstimos e financiamentos. 
Quanto ao capital, o primeiro nível, ou TIER 1, é composto pelas ações ordinárias e preferenciais não cumulativas. O segundo nível, ou TIER 2, compreende os instrumentos híbridos de capital e dívida, como ações preferenciais com cumulatividade de dividendos e bonds perpétuos; e a dívida subordinada com prazo superior a cinco anos, esta limitada a 50\% de TIER 1. O TIER 2 está limitado a 100\% de TIER 1.

Posteriormente, o BCBS estendeu as normas de capital regulatório para outros riscos incorridos pelas instituições financeiras. Em 1996 publicou o Amendment To The Capital Accord To Incorporate Market Risks, que estabelecia a alocação de capital para os riscos de mercado - taxa de juros, de câmbio, ações e commodities (BCBS, 1996); e em 1998 publicou o Operational Risk Management, visando criar um padrão para a gestão dos riscos operacionais (BCBS, 1998).

Em 2006 o BCBS publicou o International Convergence of Capital Measurement and Capital Standards - A Revised Framework, conhecido como Basiléia II. Esse documento dividia-se em três pilares: o primeiro tratava do capital regulatório; o segundo tratava do processo de supervisão; e o terceiro pilar, era voltado para a disciplina de mercado. O primeiro pilar promoveu mudanças qualitativas no tocante ao conceito de Ativos Ponderados pelo Risco, vinculando o rating ao fator de ponderação. Foi introduzido o requerimento de capital para riscos operacionais e promoveram-se aprimoramentos no tocante a crédito e securitização (BCBS, 2006).

Em 2010 o BCBS publicou em 2010 uma revisão do acordo de capital intitulada $A$ global regulatory framework for more resilient banks and banking systems, que veio a se tornar conhecida como Basiléia III (BCBS, 2010). Dentre as mudanças da nova norma destacam-se:

- Uma nova estrutura de capital, priorizando o capital de melhor qualidade e estabelecendo restrições aos instrumentos de capital de menor qualidade. Nesta nova estrutura, o TIER 1 é subdividido em Capital Principal, composto pelas ações ordinárias e preferenciais não cumulativas; e Capital Adicional, composto por instrumentos híbridos e de dívida com características de perpetuidade. Os demais instrumentos não perpétuos compõem o TIER 2. Foram estabelecidos níveis mínimos para o Capital Principal (4,5\% de APR), para o Capital Nível 1 (6\% de APR), e para a soma de Capital Nível 1 e 2 (8\% de APR). 
- Ajustes prudenciais ao capital da instituição, isto é, deduções ao Capital Principal, que dizem respeito aos ativos intangíveis, créditos tributários, participação no capital de subsidiárias e benefícios definidos de fundos de pensão, dentre outros.

- O Capital de Conservação, destinado para fazer frente a possíveis perdas e, dentro de seus limites, permitindo que uma constituição continue a operar. O Capital de Conservação deve ser atendido com os mesmos instrumentos do Capital Principal e seu requerimento é de $2,5 \%$ de APR.

- O Capital Contracíclico, com o objetivo de garantir a estabilidade financeira da economia. Esse capital dá graus de liberdade aos bancos centrais, a medida que, fora dos tempos de crise, cria-se um colchão de capital para fazer frente às perdas em possíveis crises; e nos tempos de crise, pode-se aboli-lo para evitar uma recessão. O Capital Contracíclico deve ser atendido com os mesmos instrumentos do Capital Principal e seu requerimento é de $2,5 \%$ de APR.

A somatória de todos os itens que compõe o capital regulatório corresponde a $13 \%$ de APR, que será exigido ao final do período de transição em 2019.

Alguns trabalhos procuraram antever o impacto decorrente de Basiléia III. Cohen (2013) observou que os bancos europeus reviram sua política de dividendos com vistas a reter uma parcela maior de seus lucros e reduziram suas carteiras de ativos disponíveis para comercialização, com o intuito de elevar o capital regulatório. No entanto, de forma agregada, não tem ocorrido cortes expressivos nas carteiras de ativos. Cohen (2013) cita que os bancos com elevada capitalização e rentabilidade no pós-crise têm crescido mais que os demais, o que enfatiza a importância de balanços sólidos.

Herrala (2014) analisou os bancos na zona do Euro e verificou que, nos sete anos anteriores à implantação de Basiléia II, as instituições se antecipam à regulação bancária e relaxaram a política de crédito imobiliário; no entanto, com o advento de Basiléia III, os bancos recrudesceram sua política de crédito.

A elevação do requerimento de capital instituída por Basiléia III suscitou a crença de que haveria aperto na política de crédito dos bancos, a elevação do spread bancário, e a retração econômica. Para Slovik e Cournède (2011), as medidas irão gerar um efeito contracionista no 
Produto Interno Bruto dos Estados Unidos, União Europeia e Japão da ordem de 0,05\% a $0,15 \%$ anuais. Eles estimaram também que o spread bancário irá se elevar em 50 pontos bases ao final do período de transição ao novo Acordo, em 2019. Para reduzir o efeito recessivo das medidas, Slovik e Cournède (2011) sugerem a redução das taxas básicas de juros. Analogamente, Elliott et al (2012) concluíram que as taxas de empréstimos nos EUA, UE e Japão poderão subir 28,18 e 8 pontos bases, respectivamente.

Miles et al (2013) estudaram qual seria o capital regulatório ótimo para os bancos e ponderam que o custo de uma crise financeira e o montante de recursos públicos para fazer frente podem ser expressivos, como foi visto nas crises recentes; portanto, o nível ótimo de capital decorre do trade off entre a redução do crescimento do PIB decorrente de uma crise, com uma dada probabilidade, versus o custo para o crescimento do PIB intrínseco no capital regulatório. Miles et al (2013) sugerem que o nível ideal de capital se situa em torno dos $20 \%$ de APR, valor este consideravelmente superior ao do capital regulatório estabelecido em Basiléia III. Diferentemente dos demais estudiosos, eles não compartilham da ideia de que haverá redução dos ativos do setor bancário, pois a elevação do capital regulatório significa tão somente que uma maior parcela dos ativos será financiada pelo capital próprio, isto é, eles veem o capital sob a ótica de funding dos bancos.

Yan et al (2012) estudaram os custos e benefícios de Basiléia III no Reino Unido, com o mesmo objetivo de determinar o nível ótimo de capital. O princípio também é que os eventuais efeitos contracionistas do novo capital regulatório seriam compensados por um benefício, definido como a redução do crescimento econômico caso houvesse uma crise. Os autores concluíram que o nível ótimo de capital, definido como a soma de Capital Principal mais o buffer de conservação, é de 10\%, superior, portanto, aos 7\% de Basiléia III.

Vazquez e Frederico (2015) avaliaram os efeitos da crise de 2008 e utilizaram como amostra os demonstrativos gerados entre 2001 e 2009 de 11.000 bancos, de âmbito global ou doméstico, nos EUA na Europa. Dois índices foram considerados, como variável explicativa de insolvências: a alavancagem, medida pela relação entre patrimônio líquido e ativos; e a liquidez, pelo Net Stable Funding Ratio - NSFR. Esta variável é dada pela equação NSFR = $\sum\left(w_{i} L_{i}\right) / \sum\left(w_{j} A_{j}\right)$, em que $\mathrm{L}_{\mathrm{i}}$ e $\mathrm{A}_{\mathrm{i}}$ referem-se respectivamente ao i-ésimo passivo e ao ativo, e w é um fator que varia entre 0 e 1 e reflete a estabilidade do componente do balanço; maior o valor de w, mais estável a fonte de passivo e menos líquido é o ativo. Como indicador de 
problemas do banco os autores consideraram as situações em que: (i) o índice de Basiléia caiu abaixo de 8\%; (ii) o status do banco no sistema Bankscope alterou-se de ativo para falência, sob intervenção, dissolvido, dissolvido por fusão, ou em liquidação; e (iii) a ocorrência de downgrade do rating da Moody's para nível indicativo de insolvência. O modelo de regressão foi probit. Os autores concluíram que os bancos globais foram mais susceptíveis a insolvência quando o nível de alavancagem era excessivo; já os bancos de âmbito doméstico apresentavam como maior causa da insolvência a baixa liquidez.

Pinheiro, Savoia e Securato (2015) estudaram o impacto da implementação de Basiléia III nos bancos brasileiros, simulando a aplicação das normas que estarão vigentes em 2019. Mantidas a estrutura de capital e as carteiras existentes em 2012, diversas instituições estariam desenquadradas, por terem se baseado na estratégia de cumprimento do capital regulatório utilizando instrumentos de capital de menor qualidade, como as dívidas subordinadas. Nesse estudo, os autores classificaram os bancos em quadrantes definidos (i) pelo enquadramento à nova norma e (ii) pelo excesso de retorno sobre o custo de capital próprio; em que cada quadrante sugere uma estratégia às instituições. Assim, as instituições desenquadradas e que vêm remunerando o acionista com retornos acima do custo de capital estariam habilitadas a emitir novas ações, mas aquelas desenquadradas e com baixo retorno representam um problema maior, e poderão inclusive ser alvo de aquisição.

Outros autores dedicaram-se a analisar os efeitos gerais da regulação e supervisão bancária, sem, contudo, vinculá-los ao novo acordo de capital. A importância do tema, no tocante à prevenção das crises econômicas, é citada por Moura (2005), para quem a frouxidão da supervisão bancária contribuiu para a Crise Mexicana em 1994 e para a Crise Asiática em 2007.

Klomp e Haan (2012) investigaram os efeitos da regulação e da supervisão bancária em mais de 200 bancos em 21 países da OECD entre 2002 e 2008 e concluíram que estas medidas são mais efetivas sobre bancos que incorrem em maior risco, mas não sobre aqueles mais conservadores neste quesito. Com base nisto, os autores discutem se regulação e supervisão não deveriam levar em consideração as diferenças entre as instituições.

Guiso et al (2006) analisaram os custos da regulação das instituições financeiras nas províncias italianas, e observaram que a existência de restrições à competição elevou o custo 
do crédito e reduziu a disponibilidade de recursos; por outro lado, com a desregulamentação houve o aumento da disponibilidade de crédito e do percentual de créditos ruins.

Bertand et al (2007) estudaram a desregulamentação do setor financeiro ocorrida na França em 1985 e notaram o aumento do emprego e da eficiência alocativa de recursos do setor, a menor disposição dos bancos em resgatar empresas em dificuldades e, para as empresas mais dependentes de financiamento, uma maior disposição para empreender reestruturações. Para os autores, a desregulamentação havida suporta a visão de que um setor bancário mais eficiente ajuda fomentar um processo schumpeteriano de destruição criativa.

Não se pode negar que o capital regulatório, o elevado custo de observância das instituições financeiras e a supervisão dos bancos centrais levaram o mercado criar estruturas em que os ativos serão carregados fora do balanço das instituições e fora da supervisão dos órgãos de supervisão. Isso deu origem ao shadow banking. Na definição de Michael (2014), shadow banking ocorre quando os indivíduos e instituições, não legalmente incorporados ou regulados como os bancos, concedem crédito, cobram juros e repassam estes juros a investidores. A securitização de ativos financeiros é uma forma de shadow banking.

As preocupações acerca do efeito sistêmico da securitização vêm de longa data. Em setembro de 1992, um estudo do BCBS intitulado Asset Transfers and Securitization manifestou que a desintermediação financeira pode fazer com que os bancos comerciais percam sua importância relativa, comprometendo a capacidade dos bancos centrais em realizar sua política monetária (BCBS, 1992).

Diversos autores citam o malefício da desintermediação financeira, e responsabilizam-na por crises financeiras, dentre as quais a que assolou o mercado americano em 2008. Akhigbe e McNulty (2011) consideram que os incentivos aos modelos de operação baseado em originação e distribuição, a exemplo do que ocorre no mercado de hipotecas, levam a decisões ruins na concessão de crédito, o que contribuiu significantemente para a crise do subprime.

Adrian e Shin (2009) ressaltam que a securitização elevou a fragilidade do sistema financeiro ao permitir que os bancos e outros intermediários elevassem a alavancagem; e propuseram alternativas de regulação para prevenir crises futuras, como a restrição da alavancagem nos momentos de forte expansão, a adoção de provisões para perdas no instante que as operações 
são originadas, regras de capital contracíclico e adequação do capital para prevenir o risco sistêmico decorrente de algumas instituições específicas. Note-se que algumas dessas medidas viriam a ser adotadas em Basiléia III.

Pozsar et al (2010) ponderam que o sistema de shadow banking, embora pratique as mesmas atividades do sistema bancário tradicional, não possui acesso a alguns mecanismos, como o redesconto do Federal Reserve ou o seguro depósito (Federal Deposit Insurance). Por esta razão, esse sistema teria sido profundamente afetado durante a crise financeira.

Já alguns autores vão além, como Nersisyan e Wray (2010), que analisaram o aumento da alavancagem e pregam que o sistema financeiro como um todo, deva ser reduzido.

\subsubsection{Capital regulatório no Brasil}

O Brasil é signatário do Acordo de Basiléia. As regras de Basiléia I foram instituídas pela Resolução n 2.099; as de Basiléia II pela Resolução nº 3.490 e n 3.444; e as de Basiléia III pelas Resoluções $n^{\circ} 4.192$, com posteriores modificações, e pela 4.193.

Além dos padrões de alavancagem já referenciados, o BACEN estabelece adicionalmente valores mínimos para o capital das instituições, que é o objeto principal deste trabalho. As Resoluções que o estabeleceram são a de no 2.099/1994, 2.607/1999 e 3.426/2006. O Quadro 2 apresenta os valores mínimos de capital em função da modalidade de instituição financeira.

Quadro 2 - Valores mínimos de capital por modalidade de instituição financeira

\begin{tabular}{lc}
\hline Modalidade & Capital \\
\hline Banco comercial & $\mathrm{R} \$ 17.500 .000,00$ \\
Banco de investimento & $\mathrm{R} \$ 12.500 .000,00$ \\
Banco de câmbio & $\mathrm{R} \$ 7.000 .000,00$ \\
Sociedade de crédito, financiamento e investimento (financeira) & $\mathrm{R} \$ 7.000 .000,00$ \\
Sociedade de arrendamento mercantil & $\mathrm{R} \$ 7.000 .000,00$ \\
Sociedades de crédito imobiliário & $\mathrm{R} \$ 7.000 .000,00$ \\
Companhia hipotecária & $\mathrm{R} \$ 3.000 .000,00$ \\
\hline
\end{tabular}

Fonte: BACEN (1999; 2006)

O valor mínimo do capital dos bancos múltiplos corresponde à soma das carteiras aprovadas, sendo uma obrigatoriamente de banco. Assim, um banco múltiplo com carteiras de banco 
comercial, de banco de investimento, de crédito financiamento e investimento, de crédito imobiliário e de arrendamento mercantil deverá ter capital de $\mathrm{R} \$ 51.000 .000,00$.

As demais instituições financeiras, como corretoras e distribuidoras de títulos e valores mobiliários têm limite mínimo de capital definido em função do perfil de operações conduzidas.

\subsection{Custo de observância no setor bancário}

Os bancos são obrigados a manter elevados padrões de governança. O BCBS (2006; 2010; 2014b) justifica a manutenção destes padrões para preservar a confiança no sistema bancário, uma vez que a governança deficiente pode ocasionar: a quebra de instituições, acarretando em risco de contágio; implicações macroeconômicas; impacto nos mecanismos de segurodepósito; impactos nos sistemas de pagamento; e ônus para os contribuintes. Sheaffer, Richardson e Rosenblatt (1998) lembram que as quebras do Orange County e dos bancos Daiwa e Barings, apenas para citar alguns, vítimas de roubos, de fraudes e da ganância, podem ser atribuídas às deficiências de suas altas administrações, incapazes de criar organizações seguras e de controlá-las.

Estes elevados padrões pressupõem a existência de pessoas dedicadas a fazer cumprir as políticas de governança. Desta forma, a estrutura organizacional deve prever departamentos dedicados à auditoria interna, gestão de riscos, controles internos, compliance, e outros; e desenvolver os sistemas de informação e controle requeridos, o que requer orçamento.

Elliehausen (1998) define custo total de regulação como o custo incorrido para realizar todas as atividades impostas por ela. $\mathrm{O}$ autor o subdivide em custos de oportunidade e custos operacionais. O custo de oportunidade é aquele decorrente da perda de oportunidade de retorno imposta pela regulação. O custo operacional decorre das ações que o banco deverá desempenhar, e o autor o subdivide em custos iniciais (start up costs) e custos recorrentes (ongoing costs); o primeiro refere-se às despesas legais para a interpretação da norma, revisão de procedimentos, revisão do processo de auditoria, custos para modificação dos sistemas de informação, e outras; o segundo inclui as despesas de monitoração, despesas com a supervisão das agências reguladoras, despesas trabalhistas, despesas judiciais, despesas com o processo 
de reporte de informações, etc. Elliehausen (1998) citou que esses custos, à época, correspondiam a 12 ou $13 \%$ das despesas dos bancos, excetuadas as despesas financeiras. Esses custos seriam constituídos, em sua maior parte, de despesas de pessoal, haja vista o tempo dedicado pelos executivos da instituição em atividades de compliance. $\mathrm{O}$ autor pondera também que estes custos são um desestímulo ao surgimento de pequenas instituições; podem incentivar a consolidação da indústria em grandes conglomerados financeiros; e podem desestimular o surgimento de novos produtos financeiros, uma vez que o custo regulatório nos primeiros anos da vida do ciclo do produto pode ser elevado, face ao resultado obtido.

Segundo Garcia e Giambiagi (2010, p. 67), a observância à regulação macro prudencial resulta em custos elevados que reduzem a eficiência das instituições, muito embora se busque preservar um bem maior, que é a estabilidade sistêmica.

Em que pese os custos, Akhigbe e McNulty (2011) estudaram seus efeito da monitoração sobre o crédito de 2.295 bancos nos EUA entre 1999 e 2005 e constataram que aquelas instituições que contraíram maiores despesas salariais com a monitoração das operações de crédito são mais eficientes em lucro. Logo, segundo os autores, o custo de observância incorrido proporcionou resultados.

Berger e DeYoung (1997) usaram o método de casualidade de Granger e encontraram evidências de que empréstimos problemáticos precedem a perda de eficiência em custo das instituições; isto decorre provavelmente pelo aumento do custo de monitoração do crédito, entre outras ações. Da mesma forma, obtiveram evidências de que para um grupo de bancos considerados eficientes ao longo do tempo, o aumento da eficiência de custos, como resultado da economia dos custos, gera o aumento dos créditos problemáticos, sugerindo que estes bancos podem estar trocando uma redução de despesas no curto prazo por um aumento das despesas com inadimplência no longo prazo. Por fim, os autores identificaram que, para os bancos com baixos índices de capitalização, o aumento da alavancagem bancária também precede a perda de qualidade da carteira de crédito, como resultado de uma mudança de comportamento dos gestores, que passariam a ter uma ação mais agressiva no tocante ao risco.

Mas a discussão sobre o custo de observância não estaria completa se não abordasse os custos decorrentes das estruturas de governança corporativa. 
Levine (2004) lembra o papel central dos bancos nas economias e expõe duas razões pelas quais a governança deles seja distinta dos modelos adotados pelas demais corporações: em primeiro lugar, a qualidade dos ativos dos bancos não é rapidamente observável, dando origem a certa assimetria de informação; desta forma, os bancos conseguiriam esconder os créditos problemáticos durante algum tempo. Em segundo lugar, os bancos são pesadamente regulados, em função da opacidade de seus ativos e de suas atividades. Segundo Levine (2004), a existência dessa regulação faria com que se confiasse excessivamente nela, o que tenderia a enfraquecer certos mecanismos tradicionais de governança.

Adams e Mehran (2003) compararam aspectos da governança corporativa de bancos e de indústrias e concluíram que os bancos possuem conselhos e administração maiores e com maior percentual de conselheiros externos. Bancos também possuem maior número de comitês, que se reúnem com maior frequência. Os autores justificaram as diferenças em função das distintas oportunidades de investimento nos dois setores, e por imposição do ambiente regulatório do setor bancário. É razoável admitir que uma estrutura de governança mais robusta tenha maior custo.

Alguns autores pesquisaram os efeitos da governança sobre o resultado das instituições. Aebi et al (2011) constataram que, durante a crise bancária havida nos EUA em 2007/2008, os bancos em que o Chief risk officer - CRO - se reportava ao Conselho de Administração apresentaram melhor desempenho, em termos de retorno sobre o patrimônio, do que aqueles em que o $C R O$ se reportava ao Chief executive officer ou qualquer outra instância, enfatizando a importância para as instituições financeiras do que se convencionou chamar de risk governance, ou governança voltada para o risco.

Laeven e Levine (2009) estudaram a questão da governança, regulação bancária e o apetite para risco dos bancos, utilizando uma amostra de 270 instituições em 48 países, utilizando informações de 1996 a 2001. As evidências apontaram que os bancos em que o acionista tem maior poder são maiores tomadores de risco. Isto é consistente com a teoria de que o acionista tem maior incentivo para tomar risco do que o gestor.

Ao longo dos anos, o BACEN se esmerou em comunicar um padrão elevado no tocante a controles internos. Várias normas foram estabelecidas nesse sentido, e todas elas tornaram obrigatória a criação de estruturas específicas, inclusive com diretores designados. Pode-se 
citar a Resolução no 2554/1998 que trata dos controles internos, a Resolução no 3.380/2006 que versa sobre os riscos operacionais, a Resolução $n^{0}$ 3.464/2007 sobre os riscos de mercado, a Resolução $n^{\circ} 3.488 / 2007$ sobre os riscos cambiais, a Resolução ${ }^{\circ} 3.721 / 2009$ sobre riscos de crédito, e outras mais. A título de exemplo, esta última traz em seu texto:

Art. $8^{\circ}$ A atividade de gerenciamento do risco de crédito deve ser executada por unidade específica nas instituições de que trata o art. $1^{\circ}$.

$\S 1^{\circ}$ A unidade a que se refere o caput deve ser segregada das unidades de negociação e da unidade executora da atividade de auditoria interna, de que trata o art. $2^{\circ}$ da Resolução $n^{\circ} 2.554$, de 24 de setembro de 1998 , com a redação dada pela Resolução nº 3.056, de 19 de dezembro de 2002.

\section{$[\ldots]$}

Art. 12. As instituições mencionadas no art. $1^{\circ}$ devem indicar diretor responsável pelo gerenciamento do risco de crédito.

$\S 1^{\circ}$ Para fins da responsabilidade de que trata o caput, admite-se que o diretor indicado desempenhe outras funções na instituição, exceto as relativas à administração de recursos de terceiros e realização de operações sujeitas ao risco de crédito.

(BACEN, 2009)

O Artigo $8^{\circ}$ impõe à instituição a constituição de uma estrutura específica com a finalidade de gerir os riscos de crédito, o que implica na contratação de profissionais e desenvolvimento de sistemas; o Artigo $12^{\circ}$ impõe a designação de um diretor responsável para a finalidade. Fica evidente, portanto, a existência do custo de observância.

Note-se no $\S 1^{\circ}$ do Artigo $12^{\circ}$ que o BACEN admite a existência de superposição de funções, em que o diretor responsável pela estrutura de gerenciamento em questão possa vir a subordinar outras áreas, exceto nas situações em que se deva preservar a segregação de funções. No caso da Resolução $n^{\circ} 3.721 / 2009$, a segregação entre a área de gerenciamento de risco e a área de negócios deve-se ao fato de que esta última ser eminentemente operacional, e seu resultado gerencial é proveniente do retorno das operações contratadas; logo, ao gestor desta área interessa franca liberdade para conceder e contratar operações de crédito, sem restrições. Por outro lado, não é habitual que o gestor de riscos tenha seu resultado gerencial vinculado às operações em carteira - própria ou de terceiros - e suas deliberações baseiam-se em uma análise isenta e em critérios puramente técnicos. Na prática, instituições menores tendem a concentrar diversas funções abaixo do mesmo executivo, desde que não haja 
conflito com as normas. A título de exemplo, os bancos Moneo e Randon, ambos sediados em Caxias do Sul - RS e cujas autorizações para a constituição foram concedidas respectivamente em 2005 e 2009, relacionam isoladamente apenas três diretores em seu quadro $^{1}$, o que denota a existência de superposição de funções.

Mas o custo de observância não se restringe à obrigatoriedade de se designar diretores e de criar estruturas de gerenciamento de riscos, mas abrange também o esforço no sentido de encaminhar diariamente ao BACEN um considerável volume de informações. O BACEN já manifestou preocupação com os elevados custos de observância das instituições. Em discurso proferido em 19 de fevereiro de 2013, o presidente do Banco Central do Brasil, Alexandre Tombini, lançou as bases do Programa Otimiza BC, que tem como objetivo a redução do custo administrativo das instituições. Desta forma, processos e procedimentos serão revistos e racionalizados, particularmente aqueles que resultem em fluxo de informações entre o BACEN e o Sistema Financeiro, reduzindo assim o custo de observância (BACEN, 2013a).

Blum e Nakane (2005) elaboraram um modelo segundo o qual o custo de regulação sobe à medida que o Índice de Basiléia cai e se aproxima dos limites do capital regulatório, pois os fiscalizadores tenderiam a ser mais restritivos, por exemplo, impondo restrições à atividade ou exigindo uma política de provisionamento mais rigorosa. Segundo os autores, ocorre uma disrupção nesta curva quando o Índice de Basiléia torna-se inferior ao limite estabelecido, pois passariam a ser exigidas novas medidas além das citadas, como um plano de capitalização, interrupção do pagamento de dividendos, e até mesmo a decretação da liquidação do banco.

\subsection{Eficiência bancária e economia de escala}

Em microeconomia, a eficiência está associada à capacidade de transformar insumos (os inputs) em produtos (os outputs), o que pode ser equacionado com a função de utilidade de Cobb-Douglas (PINDYCK; RUBINFELD, 2004, p. 142; p. 246). Comumente se considera

\footnotetext{
${ }^{1}$ Dados da página Informações Cadastrais e Contábeis do sítio do BACEN.
} 
como inputs o capital e o trabalho. Os conceitos de eficiência e ineficiência, ou X-efficiency e X-inefficiency, são explicados por Leibenstein (1978, p.17), segundo o qual X-efficiency decorre da utilização máxima dos insumos disponíveis, e $X$-inneficiency é a diferença entre o produto real e o produto máximo, para um dado volume de insumos.

A eficiência bancária é tema central quando se discute a viabilidade das instituições e diversos estudos trataram do assunto, dada sua relevância. Berger, Hunter, e Timme (1993) pesquisaram a literatura publicada até então, cujos temas abrangiam: as economias de escala e escopo; a eficiência (X-Efficiency); os efeitos sobre a eficiência decorrentes das fusões; a eficiência das instituições governamentais de empréstimos; e a eficiência do setor de seguros. Os autores justificaram a importância desses estudos em função do cenário de mudanças da época, quando então o segmento de poupança e empréstimo americano estava virtualmente em colapso, o segmento de seguros vivia intensa pressão fiscal, e os bancos engajavam-se em um movimento de fusões sem precedentes. Os autores agruparam os fatores determinantes da eficiência bancária em: problemas de agência, regulação e estruturas legais, e a economia de escala e escopo das instituições.

Berger, Hancock e Humphrey (1993) estudaram a eficiência dos bancos comerciais americanos entre 1984 e 1989 e afirmaram que a metade dos resultados potenciais é perdida para as ineficiências. Os autores identificaram que a maior parte das ineficiências decorre na capacidade de geração de receitas, e não das despesas; e que grandes bancos tendem a ser mais eficientes do que os menores.

Berger e Humphrey (1997) relacionaram 130 estudos sobre o tema, que utilizaram técnicas não paramétricas (Data Envelope Analysis, ou DEA; e Free Disposable Hull, ou FDH) e técnicas paramétricas (Stochastic Frontier Analysis, ou SFA; Distribution-Free Approach, ou DFA; e Thick Frontier Approach, ou TFA), abrangendo os dados de 21 países. Na média, o ranking de eficiência situou-se em $77 \%$, com mediana de $82 \%$. Esses estudos, no entanto, apresentaram um desvio padrão entre si de $13 \%$, que os autores consideraram elevado. Berger e Mester (1997) procuraram entender as razões desse desvio e estudaram a eficiência de custos, a eficiência padrão de lucros e a eficiência alternativa de lucros. A eficiência padrão de lucro baseia-se no máximo lucro possível para um determinado nível de preço dos insumos e dos preços de produção, enquanto que a eficiência alternativa de lucros diferencia-se por utilizar a quantidade de recursos utilizados na produção, ao invés de seus preços. A conclusão 
a que chegaram foi que estas formas de eficiência não se correlacionam entre si, e sugeriram que, em futuros trabalhos sobre eficiência bancária os três aspectos fossem explorados.

Clark (1996) estudou a eficiência de pouco mais de uma centena de bancos comerciais americanos entre 1988 e 1991. Em sua análise, o autor incluiu, além do custo de produção, o custo econômico decorrente do custo de oportunidade do capital, baseado na premissa de maximização do valor para o acionista. O modelo adotado foi o de fronteira estocástica (thick frontier), cujas variáveis de saída (outputs) foram: (i) os empréstimos à indústria e comércio, e leasing; (ii) financiamento ao consumo e crédito imobiliário; (iii) a carteira de títulos; e (iv) os depósitos. Como variáveis de entrada (inputs) foram considerados: (i) as despesas com pessoal; (ii) as demais despesas administrativas; e (iii) o custo médio ponderado de capital, onde o capital próprio foi estimado pelo CAPM. As evidências apontaram que a ineficiência de custo econômico é baixa e não varia com o tamanho do banco, mas a ineficiência dos custos de produção é maior e correlacionado com o tamanho. Segundo o autor, isto suporta a idéia de que muitos bancos têm priorizado a redução do custo de produção, sem dar suficiente atenção para o risco, que reflete no custo econômico. Clark não achou evidências de que as eficiências de produção e econômica cresçam quando o banco expande sua carteira de ativos além de 2 bilhões de dólares de ativos totais.

Jagtiani, Nathan e Sick (1995) estudaram a eficiência procurando compreender os efeitos dos off-balance-sheet instruments - OBS, motivado pelo crescimento desses contratos nos anos 1980. A análise baseou-se nos demonstrativos de dezembro de 1988, seis meses após a entrada em vigor do Acordo de Capital de 1988 e utilizou a função translog ou logarítmica transcendental, que é uma generalização da função de produção de Cobb-Douglas. A amostra incluiu 14.000 bancos, dos quais 134 estavam engajados em OBS. As variáveis consideradas foram: (i) ativos financeiros; (ii) depósitos; (iii) OBS decorrente de garantias; (iv) OBS de taxas de câmbio; (v) OBS de taxas de juros; (vi) trabalho; (vii) capital físico, dado pela relação entre as despesas administrativas e o ativo total; e (viii) o capital financeiro, dado pela relação entre juros pagos e depósitos. Os autores encontraram evidências de que a eficiência varia com o perfil do output, e que os instrumentos OBS afetam pouco as medidas de economia de escala. As evidências também apontaram que o volume dos instrumentos OBS acarretaram pequeno ou nenhum impacto nos custos dos bancos, o que sugere que esses contratos poderiam crescer sem limitações, o que recomenda medidas de requerimento de capital. 
Tabak et al (2011), ao estudarem os bancos na América Latina, concluíram que eles trabalham em níveis mais elevados de eficiência em custos do que eficiência em lucro. Melhor gestão dos custos não significa necessariamente que eles estão obtendo o retorno adequado. Segundo os autores, existem indícios de que bancos privados e bancos estrangeiros são mais eficientes em lucro e custos do que os bancos públicos. No entanto, a discussão sobre quais bancos são os mais eficientes, se os privados ou os públicos, os nacionais ou os estrangeiros, é assunto controverso e está longe de se esgotar. Ruiz et al (2008) enumeraram diversos trabalhos com conclusões similares às de Tabak et al (2011), mas também outros com conclusões opostas. A título de exemplo, os estudos sobre os bancos brasileiros conduzidos por Silva e Jorge Neto (2002) e de Nakane e Weintraub (2005) apontam para a maior eficiência dos bancos privados; já na Índia, Altunbas et al (2000) e Sensarma (2006) concluíram que os bancos públicos são os mais eficientes. A questão de eficiência encontra discrepâncias não somente no que tange às conclusões, mas também no tocante aos métodos utilizados para mensuração da eficiência e ao fato de que esta pode variar ao longo do tempo em função de atitudes governamentais, aumento da competitividade e mudanças das administrações (RUIZ et al, 2008).

Arantes e Rocha (2012) analisaram as eficiências de custo e de lucro dos bancos brasileiros ao entre 2003-2010. Os resultados obtidos, a partir da análise de fronteira estocástica, apontaram que enquanto a eficiência de lucro foi afetada negativamente pela crise de 2008, a eficiência de custo foi afetada positivamente. Isto pode ser um indicativo que, durante períodos de crise, os bancos buscam maior racionalização dos componentes do custo, por se tratar de variáveis de mais fácil controle. Os componentes da receita, no entanto, foram os mais afetados nesses períodos, pois dependem de fatores exógenos aos bancos. Ao estudarem os efeitos da crise financeira global de 2008, Arantes e Rocha (2012) concluíram que em instantes de crise os bancos procuram alcançar maior racionalização dos custos, por possuírem controle sobre estas variáveis; por outro lado, as receitas são as mais afetadas por dependerem de fatores exógenos à instituição.

Alguns autores estudaram a relação entre o porte da instituição e a eficiência e economia de escala. Akhigbe e McNulty (2003) estudaram o efeito da dimensão sobre a eficiência em lucro dos bancos americanos dentre 1990 e 1996 e concluíram que os bancos pequenos, com ativos inferiores a 500 milhões de dólares, são mais eficientes em lucro do que os grandes bancos. E dentre os pequenos, aqueles localizados fora de regiões metropolitanas são mais eficientes em 
lucro do que os localizados nas metrópoles, suscitando a hipótese de um ambiente competitivo mais acirrado nas grandes centros.

Humphrey (1990) avaliou os trabalhos sobre o ganho de escala do setor e citou que é consensual a idéia de que existem economias de escala nos bancos menores, mas deseconomias naqueles de maior porte. Em contraposição, McAllister e McManus (1992) identificaram que os ganhos de escala não estão restritos aos bancos de menor porte, mas se estendem também nos grandes conglomerados financeiros, alegando a existência de problemas de ordem econométrica em estudos anteriores.

O processo de integração européia e a consolidação dos bancos no continente levaram Cavallo e Rossi (2001) a estudarem os ganhos com economia de escala e escopo dos bancos da região, utilizando dados de 442 bancos entre 1992 e 1997. Eles obtiveram evidência de que as mudanças havidas na regulação e na tecnologia favoreceram a economia de escala. Eles agruparam os bancos em três classes, de acordo com seu porte, e identificaram que a economia de escala é crescente para todas as classes, embora a magnitude dos ganhos dos bancos de menor porte tenha sido pouco maior. Quanto à economia de escopo, todas as classes apresentam economias crescentes, mas com maior magnitude para os bancos de maior porte. A significante economia de escopo corrobora com as previsões de que a transição para o banco universal da Segunda Diretiva Bancária Européia aumentou o grau da economia de escopo.

De Paula e Faria (2007) fizeram uma análise por envoltória de dados, em que os bancos brasileiros foram classificados em grandes bancos varejistas, bancos varejistas de alta renda, bancos varejistas regionais, bancos atacadistas e bancos especializados em crédito; nessa análise, foram avaliados as evoluções da eficiência na intermediação e na obtenção de resultados, no período compreendido entre 2000 a 2006. As evidências obtidas apontaram para a menor eficiência dos bancos varejistas regionais nos dois quesitos analisados.

Ceretta e Niederauer (2001) classificaram 144 conglomerados financeiros no Brasil, de pequeno, médio e grande porte, e mediram a eficiência operacional dos bancos de cada grupo por análise por envoltória de dados; a seguir plotaram cada grupo em uma matriz BCG, com eixo vertical representativo da rentabilidade, e o horizontal indicativo da eficiência operacional. Para os bancos pequenos e médios, parte significativa das instituições situava-se 
no quadrante de baixa eficiência e baixa rentabilidade. Os autores concluíram na época que o mercado caminharia para a consolidação, o que de fato ocorreu.

\subsection{O ambiente competitivo: podem as pequenas instituições sobreviver?}

Finalmente, existe a questão do ambiente competitivo. Alguns trabalhos foram desenvolvidos com objetivos específicos, mas que de certa forma encontraram particularidades que diferenciaram as instituições de menor porte.

Berger e Humphrey (1994) pesquisaram os efeitos de consolidação no setor bancário americano e compararam o número de instituições, por faixas de tamanho dos ativos, em 1980 e 1992. A constatação foi que, para a faixa representativa dos bancos com ativos inferiores a 50 milhões de dólares, houve uma significante redução do número de instituições (de 9.217 para 5.650) e redução do percentual de ativos detidos (de 9,4\% para 5,5\%). Berger e Humphrey (1994) apresentam algumas conclusões: a economia de escala e escopo não é tão importante, exceto para os pequenos bancos; as fusões não tem efeito significativo sobre a eficiência dos bancos; grandes bancos não verificam aumento de economia de escala quando eles se tornam maiores; e, embora as fusões aparentem ter potencial para a redução dos custos, em realidade isto não se verifica.

Humphrey e Pulley (1997) estudaram os efeitos da desregulamentação bancária nos anos 1980, que elevou o custo de captação e reduziu a lucratividade. A amostra utilizada era composta por 683 bancos americanos, que correspondiam a 45\% dos ativos bancários. Em função do porte, os bancos adotaram diferentes estratégias para reconduzir suas taxas de retornos aos níveis anteriores. Enquanto os bancos maiores, com ativos superiores a 500 milhões de dólares, limitaram-se a ajustar o preço de saída de seus produtos, os menores, com ativos entre 100 e 500 milhões de dólares, realizaram outros ajustes para recuperar sua lucratividade. Este estudo, e o anteriormente discutido, mostram que as instituições menores podem ser mais flexíveis para se adaptar às situações.

Em que pese a preocupação com a sobrevivência dos bancos pequenos face à tendência de consolidação do setor, para Carter et al (2004) eles são mais eficientes em suas decisões de crédito do que os grandes bancos. Eles analisaram os dados de bancos comerciais americanos 
entre 1996 e 2001 e constataram que o retorno ajustado ao risco se reduz à medida que a dimensão da instituição cresce. Isso seria o resultado do fato de que bancos pequenos têm melhores informações para a concessão de crédito, advindo do desenvolvimento de bons relacionamentos, do uso de soft information ${ }^{2}$ e também em função de suas estruturas organizacionais.

Berger et al (2005) também estudaram as praticas de créditos de pequenos e grandes bancos, para testar a teoria de que os pequenos têm vantagem comparativa nas atividades que requerem soft information. A pesquisa utilizou dados do National Survey of Small Business Finance $-\mathrm{NSSBF}^{3}$ de 1993 e baseou-se em empresas pequenas, com média de valor contábil dos ativos de três milhões de dólares. As conclusões a que chegaram são de que os grandes bancos priorizam empréstimos para grandes empresas com bons registros contábeis, enquanto pequenos bancos emprestam aos créditos mais problemáticos. Os grandes bancos interagem com os devedores de forma mais impessoal; mantêm relacionamentos mais breves e menos exclusivos; e não são flexíveis em aliviar as restrições crédito. Berger et al (2005) encontrou significância estatística nestas análises, o que é consistente com a hipótese de que os bancos pequenos têm uma vantagem comparativa na concessão de empréstimos com base em soft information.

Berger et al (2011) foram além. Em primeiro lugar, eles estudaram as tecnologias de financiamento colateralizadas por ativos fixos e concluíram que os bancos maiores têm clara vantagem comparativa nas operações de leasing, relativamente a outros empréstimos também garantidos por ativos fixos, o que se contrapõe ao paradigma de que os bancos maiores têm vantagem comparativa sempre que usam hard information. Em segundo lugar eles constataram que a vantagem comparativa dos bancos de maior porte ao fazerem uso de hard information não cresce monotonicamente com o porte do tomador do crédito; ela é maior para

\footnotetext{
2 Soft information é a informação baseada em opiniões, idéias, rumores, planos, projeções econômicas e comentários do mercado, de difícil sumarização por números; em contraposição, hard information é a informação quantitativa fácil de ser guardada, obtida de forma impessoal, e seu conteúdo não depende da forma como foi coletada (PETERSEN, 2004).

${ }^{3}$ Pesquisa realizada pelo Federal Reserve
} 
as pequenas e grandes empresas, mas menor para aquelas de médio porte. Em terceiro lugar, os bancos de menor porte têm vantagem comparativa nos empréstimos baseados em relacionamento, mas ela é mais forte à medida que cresce o porte da empresa financiada.

O efeito econômico dos bancos de menor ou maior porte pode ser vista também sob a ótica do tomador de crédito. Jayaratne e Wolken (1999) pesquisaram o efeito da presença de bancos de pequeno porte no crédito das pequenas empresas. Os autores partiram da premissa de que pequenos bancos tem vantagem sobre os maiores a este respeito, no que eles chamaram de hipótese do Small Banks Advantage; desta forma, firmas menores teriam dificuldade em obter linhas de crédito em regiões com poucas instituições de pequeno porte. Usando dados dos tomadores de crédito provenientes do 1993 National Survey of Small Business Finance, concluíram que a probabilidade de uma empresa menor de obter linha de crédito bancária não se reduz quando a região possui poucos bancos de pequeno porte. Por outro lado, no curto prazo, as evidências são de que as linhas de crédito a estas firmas se reduzem concomitantemente com o número de pequenos bancos. A pesquisa realizada também não obteve evidências de que pequenas empresas localizadas em regiões com poucos bancos pequenos têm a tendência de pagar seus créditos com mais atraso, o que sugere que estas firmas não tem mais restrição ao crédito do que aquelas localizadas em regiões com muitos bancos de pequeno porte. Com base nisto, os autores acreditam que, no longo prazo, a consolidação bancária não cause efeitos de restrição ao crédito das pequenas empresas.

Demsetz e Strahan (1997) estudaram a relação entre o porte e o risco das instituições. Eles se basearam em dados de 130 conglomerados financeiros cujas ações eram listadas na NYSE e na AMEX entre 1980 e 1993 e vincularam seu porte à diversificação e ao risco, medido pela variância do preço das ações. Os autores concluíram que os conglomerados maiores, de fato, conseguem diversificar melhor os ativos, mas isto não significa a redução dos riscos; e que o menor risco decorre de menor coeficiente de alavancagem e de uma maior proporção de empréstimos destinados à indústria e ao comércio.

Alguns trabalhos publicados dedicaram-se à questão da consolidação bancária no Brasil. De Paula e Marques (2004) estudaram as motivações para a consolidação bancária relacionadas pelo Banco Central Europeu e fizeram uma análise do caso brasileiro. Para os autores, a transição para um regime de baixa inflação, no pós Plano Real, retirou do sistema bancário as receitas inflacionárias, ocasionando a reestruturação do setor com o PROER e o PROES. 
Além disso, a desregulamentação havida, com a abertura do mercado doméstico ao capital estrangeiro, precipitou um movimento e aquisições por parte dos grandes conglomerados bancários nacionais.

No que tange à concentração, De Paula et al (2014) analisaram a concentração de mercado no Brasil com base em dados do Consolidado Bancário I do BACEN, que compreende todos os bancos com carteira comercial. Os dados referem-se ao período de 2005 a 2009. A análise baseou-se no Índice de Hirschman-Herfindal - IHH, que corresponde soma dos quadrados das participações de mercado, e contemplou as contas Ativo Total, Operações de Crédito e de Arrendamento Mercantil, Depósitos, Agências, Funcionários, e Títulos e Valores Mobiliários e Instrumentos Financeiros Derivativos. Nesta análise, no período que antecedeu a crise de 2008 o sistema bancário era considerado uma indústria moderadamente concentrada, com IHH entre 0,1 e 0,18 . No pós crise identificou-se uma substancial elevação da concentração nos quesitos Operações de Crédito, com o índice IHH aproximando-se de 0,25, ou 2500 pontos. A justificativa, segundo os autores, foi a aquisição de carteiras de instituições com problemas pelos bancos públicos, notadamente Banco do Brasil e Caixa Econômica Federal, e o papel contracíclico desempenhado pelo BNDES.

Existe a preocupação de que a concentração bancária brasileira comprometa a sobrevivência das instituições de menor porte. Souza e Novais (2014) analisaram esta concentração, em que os cinco maiores bancos detém $85 \%$ dos ativos do mercado. Segundo eles, o IHH está próximo de 1800 pontos, número este considerado elevado pela autoridade antitruste e pelo BACEN.

Este nível de concentração bancária é impactante no resultado das instituições. Grandes conglomerados financeiros conseguem diversificar as fontes de funding, com acesso ao mercado de capitais e aos investidores de varejo, dada sua maior capilaridade, o que lhes garante um menor custo global de captação; possuem amplos portfólios de produtos; e conseguem obter economia de escala, tal é o volume de suas operações. Na Tabela 1 foram transcritos dados do Relatório de Estabilidade Financeira, do BACEN. 
Tabela 1- Retorno sobre o patrimônio líquido dos bancos no Brasil

\begin{tabular}{clrrrr}
\hline & Intervalo do ROE & dez/13 & jun/14 & dez/14 & jun/15 \\
\hline & ROE $<0$ & 44 & 35 & 25 & 30 \\
Quantidade de & $0<$ ROE $<0,85 *$ Selic & 36 & 39 & 47 & 44 \\
Instituições & ROE $>0,85 *$ Selic & 51 & 58 & 60 & 59 \\
Financeiras & Total & 131 & 132 & 132 & 133 \\
\hline & ROE $<0$ & 182,2 & 188,1 & 206,2 & 209,7 \\
Total de ativos em & $0<\mathrm{ROE}<0,85 *$ Selic & 310,9 & 346,7 & 302,4 & 351,0 \\
R \$ bilhões & ROE $>0,85 *$ Selic & $4.006,5$ & $4.215,2$ & 4473,2 & 4682,4 \\
& Total & $4.499,6$ & $4.750,0$ & 4981,8 & 5243,1 \\
\hline \multirow{3}{*}{$\begin{array}{c}\text { Participação \% nos } \\
\text { ativos do sistema } \\
\text { bancário }\end{array}$} & ROE $<0$ & 4,1 & 4,0 & 4,1 & 4,0 \\
& ROE $>0,85 *$ Selic & 6,9 & 7,3 & 6,1 & 6,7 \\
\hline & Total & 89,0 & 88,7 & 89,8 & 89,3 \\
\hline
\end{tabular}

Fonte: Dados dos Relatórios de Estabilidade Financeira (BACEN, 2014a; 2015a)

Na Tabela 1 pode-se notar que os balanços de junho de 2015 apresentavam 30 bancos com retornos sobre o patrimônio negativos, 44 com retornos entre zero e $85 \%$ da taxa SELIC, e 59 bancos com retornos superiores a $85 \%$ da taxa SELIC; esta última classe concentra 89,3\% dos ativos do mercado. Logo, os 74 bancos com retornos inferiores a 85\% da taxa SELIC, com 10,7\% dos ativos do mercado, são pequenos e médios. Números semelhantes são observados nos três balanços anteriores. Isto suscita a hipótese de que as condições de competitividade não são favoráveis aos bancos de menor porte.

\subsection{Síntese}

Conforme apresentado, a atividade bancária é fortemente regulada e possui limites para coibir excessivas exposições a risco. As regras de alavancagem podem resultar em efeito contracionista, segundo alguns estudiosos, mas este efeito é pequeno se comparado àquele decorrente de uma crise sistêmica.

A preocupação com o risco das instituições financeiras faz com que o processo de supervisão dos bancos centrais seja rigoroso, e obriga os bancos a prestarem uma série de informações e a possuir estruturas para o gerenciamento dos riscos, o que implica elevados custos de observância. Estes custos, quando se considera uma instituição de menor porte, podem ser excessivos. 
Diversos estudos apontam resultados divergentes sobre a vantagem comparativa dos pequenos bancos. Os bancos de menor porte têm maior capacidade em obter ganhos de escala, segundo Humphrey (1990) e Rossi (2001); são possuidores de maior eficiência, para Akhigbe e McNulty (2003); e têm maior eficiência na concessão de crédito, segundo Carter et al (2004). Em contraposição, Ceretta e Niederauer (2001) concluíram que eles são menos eficientes; e o Relatório de Estabilidade Financeira do BACEN (2014), aponta que os retornos são inferiores àqueles observados nos grandes conglomerados financeiros. É interessante notar que Humphrey (1990), Rossi (2001) e Akhigbe e McNulty (2003) estudaram bancos americanos, enquanto que Ceretta e Niederauer (2001) estudaram bancos brasileiros. Isto levanta a hipótese de que as condições de competitividade das instituições de menor porte no Brasil possam ser mais desfavoráveis, o que suscita a necessidade de investigar a partir de que porte os bancos passam a ser viáveis. 
Este capítulo foi motivado pela discussão acerca da concentração bancária no Brasil. Será apresentada uma breve análise das estatísticas de participação de mercado e dos resultados das instituições financeiras, agrupadas segundo seu respectivo Consolidado Bancário, conforme detalhado no Quadro 3. Como se evidenciará, os grandes conglomerados financeiros detêm a maior parte dos ativos do Sistema Financeiro Nacional (SFN) e dos depósitos; e auferem retornos superiores àqueles dos bancos de menor porte. Serão avaliadas também instituições financeiras constituídas em passado recente no que tange a seu retorno.

Quadro 3 - Consolidados do SFN

\begin{tabular}{|c|c|c|}
\hline Consolidado & Instituições contidas & $\begin{array}{c}N^{o} \text { de Instituições no } \\
\text { Relatório TOP50 de } \\
\text { dez/2014 }\end{array}$ \\
\hline Consolidado Bancário I & $\begin{array}{l}\text { Bancos comerciais ou bancos múltiplos com carteira } \\
\text { comercial. }\end{array}$ & 96 \\
\hline Consolidado Bancário II & $\begin{array}{l}\text { Bancos múltiplos sem carteira comercial, bancos de } \\
\text { investimento e bancos de câmbio. }\end{array}$ & 36 \\
\hline Consolidado Bancário III & Cooperativas de crédito. & 1.139 \\
\hline Consolidado Bancário IV & Bancos de Desenvolvimento. & 4 \\
\hline Consolidado Não Bancário & $\begin{array}{l}\text { Que concedem crédito: Companhias de crédito } \\
\text { financiamento e investimento (financeiras), Companhias } \\
\text { Hipotecárias, Sociedades de Crédito Imobiliário, } \\
\text { Associações de Poupança e Empréstimo, Agências de Fo- } \\
\text { mento, Sociedades de Crédito ao Microempreendedor. } \\
\text { Que não concedem crédito: Corretoras de câmbio, e de } \\
\text { títulos e valores mobiliários; Distribuidoras de Valores. }\end{array}$ & 290 \\
\hline
\end{tabular}

Fonte: BACEN

\subsection{Participação de mercado dos consolidados do SFN}

O Gráfico 1 traz a participação nos ativos totais no SFN. Os bancos com carteira comercial representam $83 \%$ dos ativos do sistema, dos quais $67 \%$ referem-se ao somatório dos cinco maiores bancos, ou seja, Banco do Brasil, Caixa Econômica Federal, Bradesco, Itaú Unibanco e Santander. Os bancos de desenvolvimento representam 18\% dos ativos, dos quais o BNDES contribui com $12 \%$. Aos demais consolidados restam apenas $5 \%$ dos ativos. 
Ativos totais

- Cinco maiores bancos

- Consolidado Bancário II

Consolidado Bancário IV

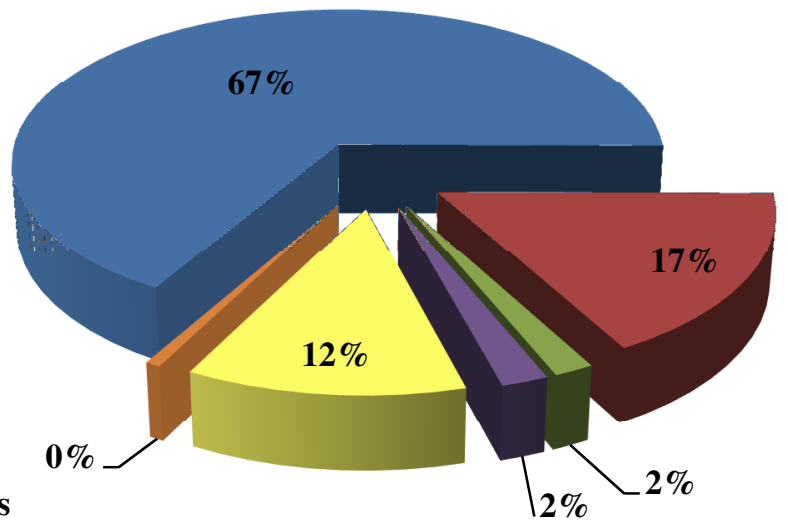

- Restante do Consolidado Bancário I

- Consolidado Bancário III

- Consolidado Não Bancário

Gráfico 1 - Participação no Ativo Total do SFN

Fonte: O Autor, com base em dados do BACEN de dez/2014

No tocante às operações de crédito e de arrendamento mercantil, o Gráfico 2 apresenta proporções semelhantes. O Consolidado Bancário I totaliza $83 \%$ dos créditos, dos quais os maiores bancos comerciais respondem por 70\%. O Consolidado Bancário IV detém 11,3\% destas carteiras, que quase inteiramente se referem ao BNDES, com 10,8\%.

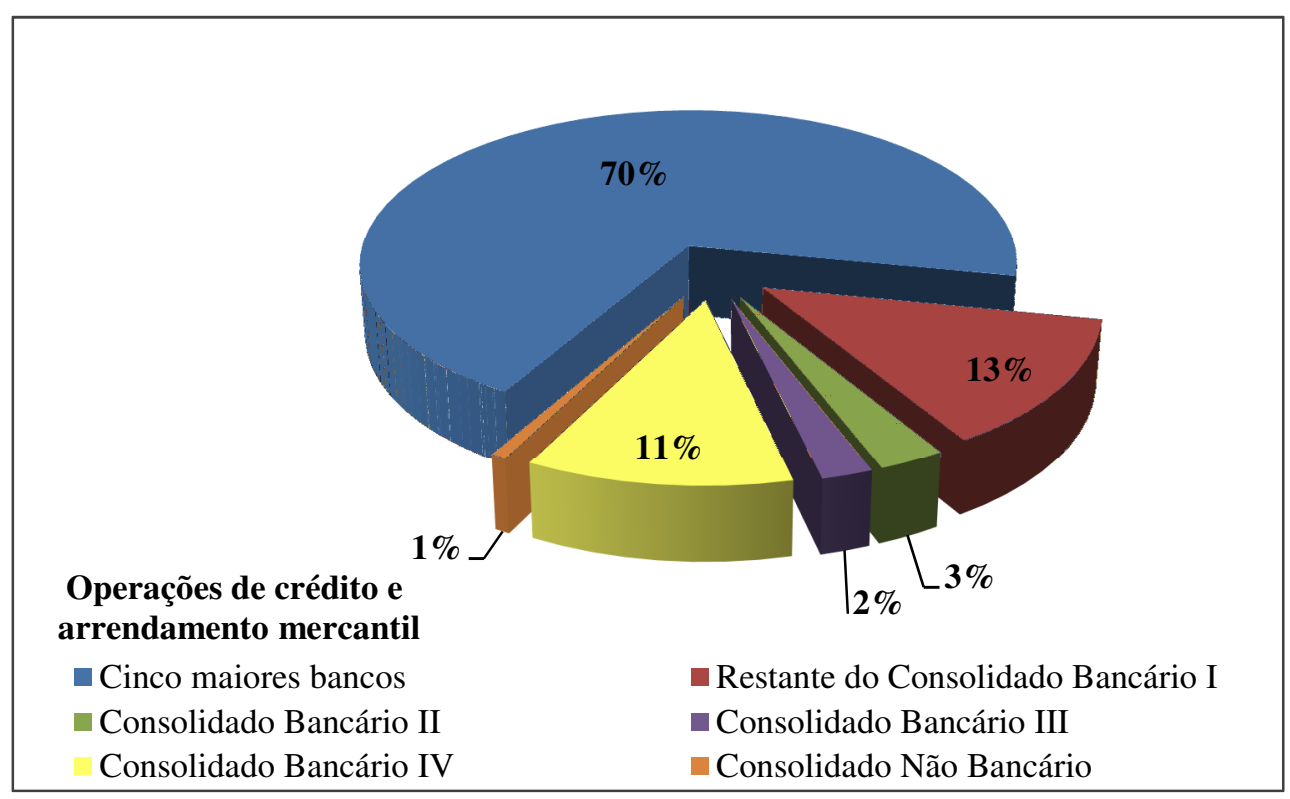

Gráfico 2 - Participação nas Operações de Crédito e de Arrendamento do SFN

Fonte: : O Autor, com base em dados do BACEN de dez/2014

O Gráfico 3 trata dos depósitos totais. O Conglomerado Bancário I detém 97\% das carteiras e os cinco maiores bancos $79 \%$. Esta concentração nos depósitos em poder das maiores 
instituições explica o porquê das instituições menores se virem em apuros quando o cenário de crédito se deteriora e ocorre o fenômeno de empoçamento da liquidez, em que os grandes bancos deixam de repassar recursos no mercado interbancário aos menores.

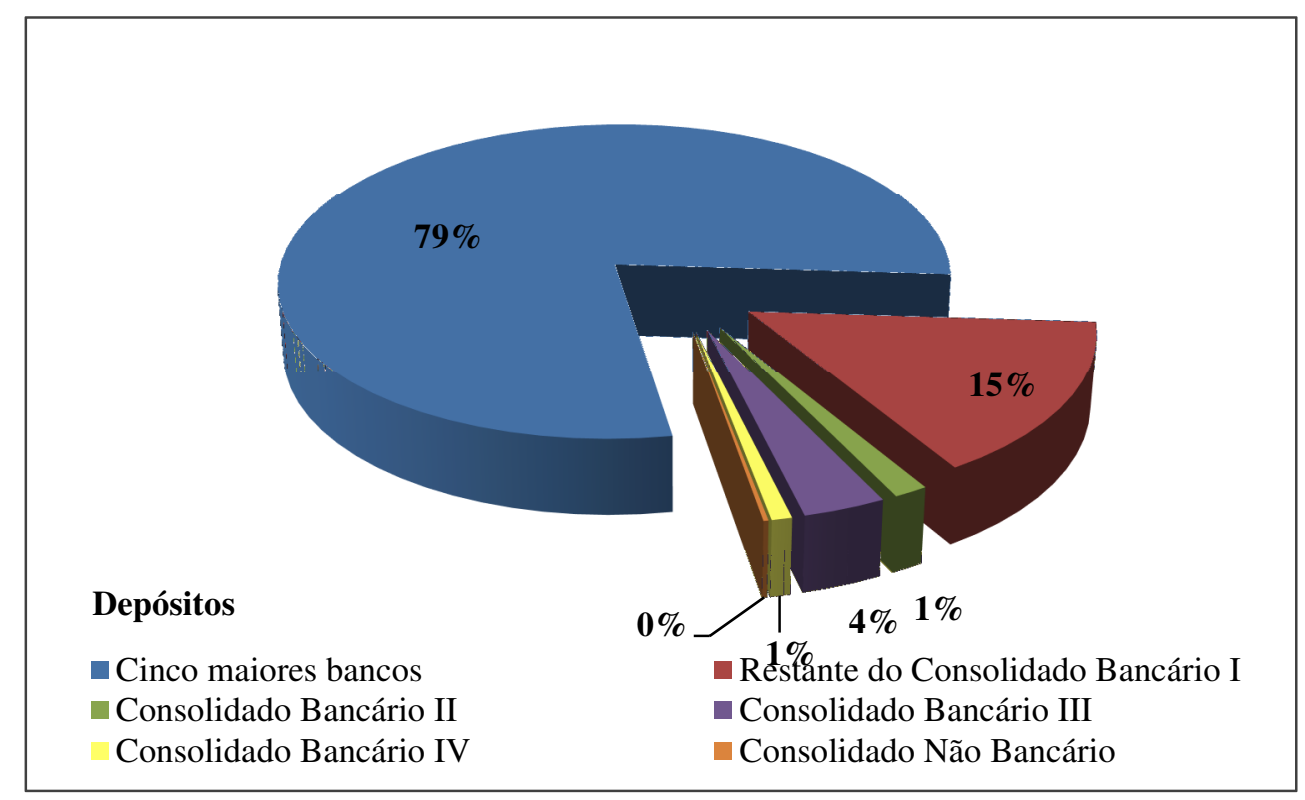

Gráfico 3 - Participação nos Depósitos Totais do SFN

Fonte: : O Autor, com base em dados do BACEN de dez/2014

O Gráfico 4 refere-se ao resultado operacional. Os bancos com carteira comercial respondem por $71 \%$ do resultado. Os cinco maiores bancos detêm $65 \%$ e os demais apenas $6 \%$.

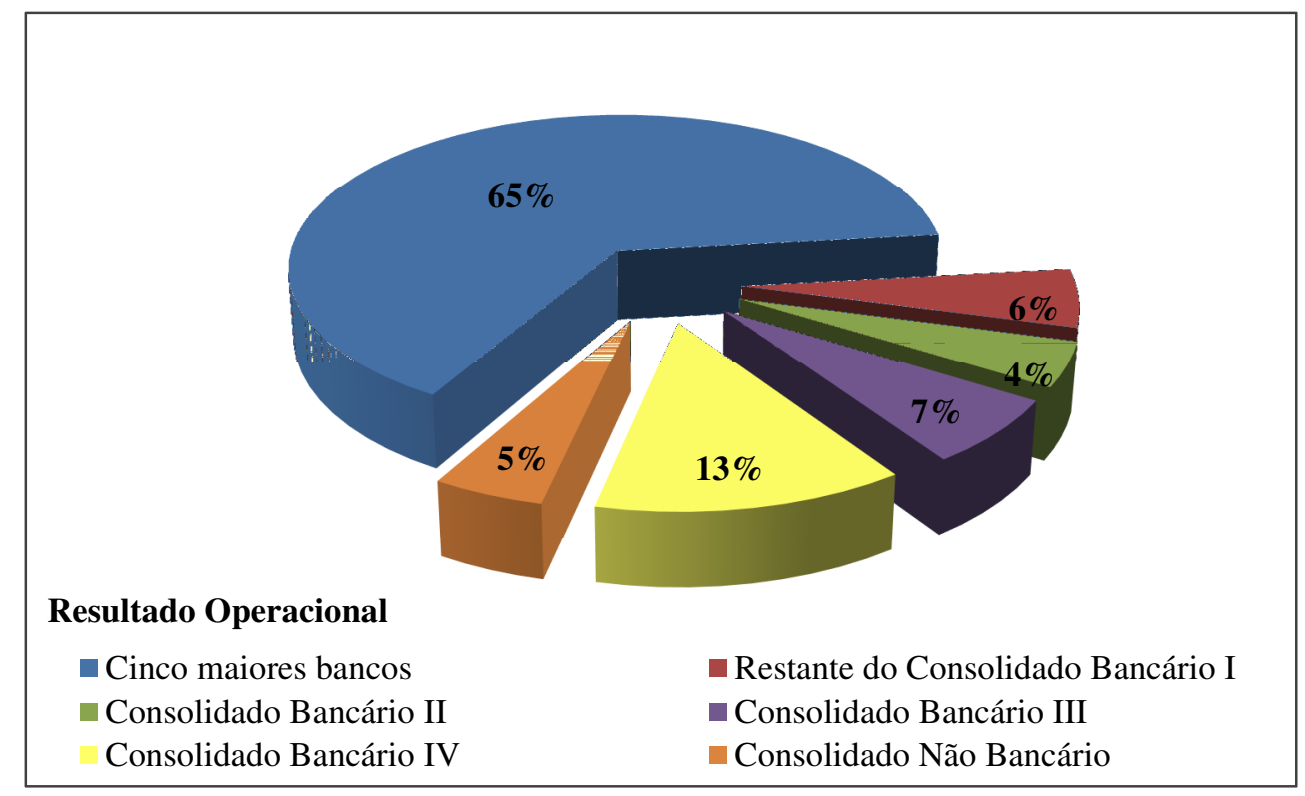

Gráfico 4 - Participação no resultado operacional do SFN

Fonte: o Autor, com base em dados do BACEN de dez/2014. 
A Tabela 2 permite fazer uma análise crítica destas participações de mercado ao apresentar a relação entre resultado operacional e ativos totais na coluna (E). Os bancos comerciais de médio e pequeno porte detêm 16,9\% dos ativos, mas cabem-lhes apenas 5,8\% do resultado operacional do SFN, ou seja, uma relação entre resultado e ativos de 0,35. Os cinco maiores bancos, integrantes do mesmo consolidado bancário, têm uma relação de 0,97. Logo, o resultado dos bancos pequenos e médios é sensivelmente inferior ao dos grandes bancos, guardada a proporção do volume de ativos.

Tabela 2 - Participação de mercado dos Consolidados Bancários

\begin{tabular}{lccccc}
\hline Consolidado & $\begin{array}{c}\text { Ativos } \\
\text { totais } \\
\text { (A) }\end{array}$ & $\begin{array}{c}\text { Operações } \\
\text { de Crédito } \\
(\mathbf{B})\end{array}$ & $\begin{array}{c}\text { Depósitos } \\
\text { (C) }\end{array}$ & $\begin{array}{c}\text { Resultado } \\
\text { Operacional } \\
\text { (D) }\end{array}$ & $\begin{array}{c}(\mathbf{E})= \\
\text { (D) : (A) }\end{array}$ \\
\hline Cinco maiores bancos & $66,8 \%$ & $69,7 \%$ & $78,8 \%$ & $64,9 \%$ & 0,97 \\
$\underline{+ \text { Demais bancos com carteira comercial }}$ & $\underline{16,9 \%}$ & $\underline{13,1 \%}$ & $\underline{15,3 \%}$ & $\underline{5,8 \%}$ & $\underline{0,35}$ \\
\hline Consolidado Bancário I & $83,7 \%$ & $82,9 \%$ & $94,0 \%$ & $70,8 \%$ & 0,85 \\
Consolidado Bancário II & $1,7 \%$ & $2,9 \%$ & $1,4 \%$ & $4,6 \%$ & 2,66 \\
Consolidado Bancário III & $2,0 \%$ & $2,2 \%$ & $3,5 \%$ & $6,7 \%$ & 3,30 \\
Consolidado Bancário IV & $12,0 \%$ & $11,4 \%$ & $0,9 \%$ & $13,2 \%$ & 1,11 \\
Consolidado Não Bancário & $0,7 \%$ & $0,7 \%$ & $0,2 \%$ & $4,8 \%$ & 7,23 \\
\hline
\end{tabular}

Fonte: BACEN

O Consolidado Bancário IV, composto pelos bancos de desenvolvimento, têm relação entre resultado e ativos compatível com o auferido pelos cinco maiores bancos.

Outros nichos do SFN têm relação entre receitas e ativos consideravelmente melhor. Estes nichos talvez não concorram diretamente com os cinco maiores bancos, diferentemente do que ocorre com os bancos com carteira comercial de pequeno e médio porte, e por isso suas fatias do resultado operacional sejam muito superiores.

\subsection{Retorno sobre o patrimônio líquido dos consolidados do SFN}

A baixa participação dos bancos de pequeno e de médio portes no resultado operacional, considerando a proporção dos ativos que detêm, reflete em seu retorno, o que é apresentado na Tabela 3, consideravelmente inferior ao custo de capital $\left(\mathrm{K}_{\mathrm{E}}\right)$, estimado em 16,35\% a.a. (vide seção 5.6.5, página 119). 
Tabela 3 - Retorno sobre o patrimônio dos consolidados do SFN - dez/2014

\begin{tabular}{lcrc}
\hline Consolidado & PL & Lucro Líquido & $\begin{array}{c}\text { ROE } \\
\text { (\% a.a.) }\end{array}$ \\
\hline Cinco maiores bancos & 339.790 .234 & 28.945 .934 & $19,49 \%$ \\
+ Demais bancos com carteira comercial & $\underline{121.499 .323}$ & $\underline{4.343 .555}$ & $\underline{7.55 \%}$ \\
\hline Consolidado Bancário I & 461.289 .557 & 33.289 .489 & $16,16 \%$ \\
Consolidado Bancário II & 17.160 .843 & 1.211 .878 & $15,77 \%$ \\
Consolidado Bancário III & 27.430 .107 & 2.384 .713 & $19,95 \%$ \\
Consolidado Bancário IV & 34.802 .761 & 3.255 .669 & $21,71 \%$ \\
Consolidado Não Bancário & 18.994 .179 & 1.136 .668 & $13,14 \%$ \\
\hline Notas: & & & \\
Valores em R\$ 1.000,00 & & & \\
\hline Fonte: BACEN. & & &
\end{tabular}

A participação dos cinco maiores bancos no Consolidado Bancário I é tão grande que o ROE do consolidado supera o custo de capital.

A Tabela 4 apresenta a evolução do retorno sobre o patrimônio do SFN, de junho/2010 a dezembro/2014.

Tabela 4 - Evolução do retorno sobre o patrimônio do SFN

\begin{tabular}{ccccccc}
\hline Balanço & $\begin{array}{c}\text { Consolidado } \\
\text { Bancário I }\end{array}$ & $\begin{array}{c}\text { Consolidado } \\
\text { Bancário II }\end{array}$ & $\begin{array}{c}\text { Consolidado } \\
\text { Bancário III }\end{array}$ & $\begin{array}{c}\text { Consolidado } \\
\text { Bancário IV }\end{array}$ & $\begin{array}{c}\text { Consolidado } \\
\text { Não Bancário }\end{array}$ & $\begin{array}{c}\text { Sistema } \\
\text { Financeiro } \\
\text { Nacional }\end{array}$ \\
\hline jun/10 & $18,66 \%$ & $10,28 \%$ & $13,42 \%$ & $26,47 \%$ & $9,03 \%$ & $18,59 \%$ \\
dez/10 & $19,80 \%$ & $15,82 \%$ & $16,74 \%$ & $21,99 \%$ & $9,47 \%$ & $19,60 \%$ \\
jun/11 & $18,88 \%$ & $12,81 \%$ & $16,96 \%$ & $17,83 \%$ & $7,89 \%$ & $18,17 \%$ \\
dez/11 & $17,76 \%$ & $12,82 \%$ & $17,59 \%$ & $13,47 \%$ & $9,13 \%$ & $16,77 \%$ \\
jun/12 & $14,20 \%$ & $6,13 \%$ & $17,43 \%$ & $10,31 \%$ & $9,87 \%$ & $13,51 \%$ \\
dez/12 & $14,63 \%$ & $8,53 \%$ & $16,58 \%$ & $23,56 \%$ & $9,99 \%$ & $15,29 \%$ \\
jun/13 & $16,50 \%$ & $4,53 \%$ & $15,48 \%$ & $17,25 \%$ & $9,81 \%$ & $15,95 \%$ \\
dez/13 & $14,71 \%$ & $8,75 \%$ & $16,13 \%$ & $24,60 \%$ & $11,80 \%$ & $15,36 \%$ \\
jun/14 & $15,17 \%$ & $12,81 \%$ & $16,27 \%$ & $28,82 \%$ & $11,48 \%$ & $16,11 \%$ \\
dez/14 & $16,16 \%$ & $15,77 \%$ & $19,95 \%$ & $21,71 \%$ & $13,14 \%$ & $16,56 \%$ \\
\hline Média & $16,65 \%$ & $10,83 \%$ & $16,66 \%$ & $20,60 \%$ & $10,16 \%$ & $16,59 \%$ \\
Desv. Pad. & $2,01 \%$ & $3,84 \%$ & $1,66 \%$ & $5,83 \%$ & $1,55 \%$ & $1,79 \%$ \\
\hline
\end{tabular}

Fonte: BACEN

Alguns pontos são dignos de nota:

- O Consolidado Bancário I, onde se inserem os grandes bancos, têm apresentado ROE 
médio superior ao custo de capital. O mesmo ocorre com as cooperativas de crédito, no Consolidado Bancário III. Ambos têm baixa variabilidade.

- O Consolidado Bancário II, composto pelos bancos de investimento, tem apresentado ROE médio pouco inferior a $11 \%$ a.a., mas com considerável variabilidade. É provável que esta oscilação do retorno seja decorrente dos ciclos econômicos que afetam o desempenho do mercado acionário.

- O Consolidado Bancário IV, em que o BNDES prevalece, apresentou ROE excepcional de 2012 para cá. Pode-se cogitar a hipótese de existirem pressões exógenas por lucratividade, visto que o resultado destes bancos afeta o superávit primário.

- Embora o Consolidado Não Bancário apresentasse em dez/2014 um ROE próximo do razoável, a média no período analisado situou-se próxima a 10\% a.a., sistematicamente abaixo do custo de capital.

O Gráfico 5 apresenta graficamente a evolução do ROE dos consolidados bancários.

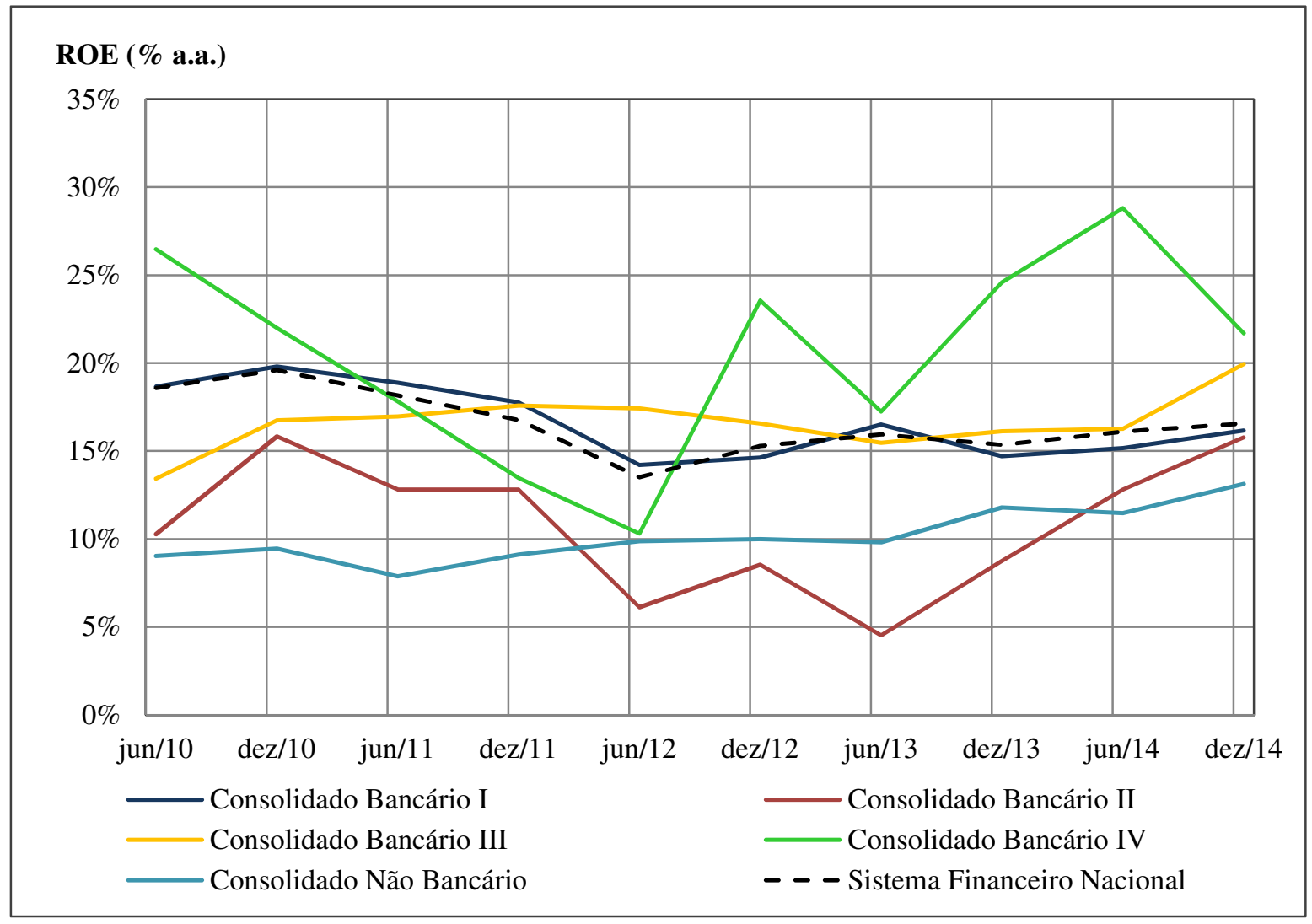

Gráfico 5 - Evolução do retorno sobre o patrimônio do SFN 


\subsection{Instituições financeiras constituídas em passado recente}

O baixo retorno apresentado pelos bancos pequenos e médios em dezembro de 2014 recomenda que se avalie o desempenho daqueles constituídos recentemente.

A Tabela 5 apresenta as autorizações para funcionamento concedidas pelo BACEN ao longo dos últimos anos.

Tabela 5 - Evolução das autorizações para funcionamento concedidas

\begin{tabular}{lccccccccccc}
\hline & $\mathbf{2 0 0 5}$ & $\mathbf{2 0 0 6}$ & $\mathbf{2 0 0 7}$ & $\mathbf{2 0 0 8}$ & $\mathbf{2 0 0 9}$ & $\mathbf{2 0 1 0}$ & $\mathbf{2 0 1 1}$ & $\mathbf{2 0 1 2}$ & $\mathbf{2 0 1 3}$ & $\mathbf{2 0 1 4}$ & $\begin{array}{c}\text { Total } \\
\text { Geral }\end{array}$ \\
\hline Banco & & & 1 & 5 & 4 & 2 & 1 & 3 & & 16 \\
Banco de Investimento & & & & 1 & & 1 & & & 1 & 3 \\
Banco de Câmbio & & & & & & 1 & & 1 & 1 & & 3 \\
Financeira & 6 & 2 & 1 & 4 & 3 & 4 & 1 & 2 & & & 23 \\
Arrendamento Mercantil & & & & & & & & 1 & 1 & & 2 \\
Cia Hipotecária & & & & & & & & & 1 & & 1 \\
Subtotal & 6 & 2 & 2 & 10 & 7 & 8 & 2 & 7 & 4 & 0 & 48 \\
Adm. de Consórcio & & & & & & & 1 & 1 & & & 2 \\
Agência de Fomento & & & & & 2 & 1 & 1 & & & & 4 \\
Cooperativa & 49 & 50 & 31 & 43 & 15 & 9 & 6 & 5 & 5 & 3 & 216 \\
Corretora (TVM e câmbio) & 3 & 1 & & 1 & 1 & 3 & 5 & 11 & 8 & 5 & 38 \\
DTVM (*1) & 2 & 2 & 5 & 5 & 5 & 2 & 6 & 2 & 3 & 1 & 33 \\
SCM $(* 2)$ & 6 & 5 & 1 & 3 & 3 & 3 & 1 & 1 & 4 & 5 & 32 \\
Total Geral & 66 & 60 & 39 & 62 & 33 & 26 & 22 & 27 & 24 & 14 & 373 \\
\hline
\end{tabular}

(*1) Distribuidora de Títulos e Valores Mobiliários

(*2) Sociedade de Crédito ao Microempreendedor

Fonte: BACEN

Com o intuito de avaliar o desempenho dos bancos recentemente constituídos, foram selecionados aqueles com carteira comercial constituídos a mais de 5 anos, mas a menos de 10 anos, relativamente a 2014. Em função da maturação destes bancos não se pode afirmar que eles se encontrem atualmente em período pré-operacional. Os bancos estão relacionados no Quadro 4, que traz também a data de publicação das autorizações para constituição no D.O. - Diário Oficial da União. 
Quadro 4 - Bancos constituídos em passado recente

\begin{tabular}{lc}
\hline Instituição & Publicação no D.O. \\
\hline Natixis Brasil S.A. Banco Múltiplo & $19-$-nov-2007 \\
Banco Azteca do Brasil S.A. & $22-f e v-2008$ \\
Banco Caixa Geral - Brasil S.A. & $01-$ dez-2008 \\
Banco Yamaha Motor do Brasil S.A. & $10-$ set-2008 \\
Concórdia Banco S.A. & 08 -ago-2008 \\
JBS Banco S.A. & 20 -mar-2008 \\
Banco da China Brasil S.A. & $20-f e v-2009$ \\
Banco Gerador S.A. & $20-f e v-2009$ \\
Banco Randon S.A. & $18-d e z-2009$ \\
Scania Banco S.A. & $4-$-dez-2009 \\
\hline
\end{tabular}

Fonte: BACEN

A Tabela 6 a seguir apresenta o patrimônio líquido destes bancos, e a Tabela 7 traz o lucro líquido auferido no semestre.

Tabela 6 - Patrimônio líquido de bancos constituídos entre 2005 e 2009

\begin{tabular}{|c|c|c|c|c|c|c|c|c|c|c|}
\hline \multirow{2}{*}{ Instituiçãa } & \multicolumn{10}{|c|}{ Balanço } \\
\hline & jun/10 & $\operatorname{dez} / 10$ & jun/11 & $\operatorname{dez} / 11$ & jun/12 & $\operatorname{dez} / 12$ & jun/13 & dez/13 & jun/14 & dez/14 \\
\hline Azteca do $\mathrm{Br}$ & 29,1 & 27,9 & 25,6 & 23,9 & 24,0 & 24,0 & 24,5 & 24,2 & 24,6 & 24,4 \\
\hline Bco da China & 135,8 & 136,5 & 137,2 & 137,8 & 138,0 & 130,6 & 129,5 & 116,3 & 231,3 & 195,3 \\
\hline Caixa Geral Br & 267,0 & & 422,1 & 418,3 & 459,7 & & 464,9 & 417,2 & 410,8 & 361,4 \\
\hline Concórdia & 75,8 & & & & & & & & & \\
\hline Gerador & 49,5 & 49,2 & 50,7 & 49,6 & 48,2 & 44,6 & 39,9 & 40,5 & 28,7 & 42,8 \\
\hline JBS Banco & 102,9 & 103,6 & 106,1 & 1887,1 & $2.045,0$ & $1.923,7$ & $2.018,3$ & $2.036,8$ & $2.060,5$ & $2.083,2$ \\
\hline Moneo & 131,1 & 135,6 & 146,7 & 151,2 & 160,0 & 166,5 & 175,0 & 173,9 & 175,8 & 184,2 \\
\hline Natixis Brasil & 97,9 & 98,8 & 102,0 & 103,2 & 108,6 & 111,2 & 111,8 & 110,8 & 120,4 & 121,3 \\
\hline Randon & & 24,0 & 23,0 & 35,2 & 47,4 & 48,0 & 74,5 & 76,4 & 79,9 & 81,2 \\
\hline Scania & 39,6 & 79,3 & 119,9 & 119,7 & 117,1 & 114,4 & & 153,5 & 210,8 & 213,0 \\
\hline Yamaha Motor & 21,2 & 30,2 & 30,4 & 45,5 & 55,8 & 59,0 & 64,4 & 70,6 & 74,0 & 86,7 \\
\hline
\end{tabular}

Valores em R\$ milhão

Fonte: BACEN 
Tabela 7 - Lucro líquido de bancos constituídos entre 2005 e 2009

\begin{tabular}{|c|c|c|c|c|c|c|c|c|c|c|}
\hline \multirow{2}{*}{ Instituição } & \multicolumn{10}{|c|}{ Balanço } \\
\hline & jun/10 & $\operatorname{dez} / 10$ & jun/11 & $\operatorname{dez} / 11$ & jun/12 & $\operatorname{dez} / 12$ & jun/13 & $\operatorname{dez} / 13$ & jun/14 & dez/14 \\
\hline Azteca do Br & 0,7 & $-1,1$ & $-2,3$ & $-1,8$ & 0,2 & 0,0 & 0,4 & $-0,3$ & 0,5 & $-0,2$ \\
\hline Bco da China & 1,3 & 0,6 & 0,7 & $-0,1$ & 0,9 & $-7,4$ & $-0,9$ & $-13,4$ & 3,6 & $-35,7$ \\
\hline Caixa Geral Br & 3,6 & & 8,6 & 8,8 & 6,4 & & $-9,9$ & $-47,7$ & $-6,4$ & $-46,8$ \\
\hline Concórdia & $-2,3$ & & & & & & & & & \\
\hline Gerador & 0,9 & $-0,3$ & 1,7 & $-1,2$ & $-1,4$ & $-3,6$ & $-4,2$ & $-11,7$ & $-11,7$ & $-17,3$ \\
\hline JBS Banco & 2,1 & 1,0 & 5,0 & 160,2 & 168,1 & $-16,8$ & 27,2 & 39,8 & 24,2 & 49,0 \\
\hline Moneo & 12,0 & 9,7 & 12,0 & 9,6 & 9,7 & 13,1 & 8,5 & 4,9 & 1,6 & 13,1 \\
\hline Natixis Brasil & 0,9 & 2,6 & 2,1 & 3,7 & 3,4 & 2,4 & 4,6 & 6,5 & 3,7 & 7,3 \\
\hline Randon & & $-1,1$ & $-1,0$ & $-0,2$ & $-0,3$ & 0,6 & 1,5 & 2,4 & 3,5 & 2,8 \\
\hline Scania & $-1,0$ & $-0,4$ & 0,6 & $-0,2$ & $-2,6$ & $-2,7$ & & $-1,1$ & 17,4 & 2,1 \\
\hline Yamaha Motor & $-3,1$ & $-1,1$ & 0,3 & 8,0 & 1,3 & 4,6 & 5,5 & 6,2 & 3,3 & 12,7 \\
\hline
\end{tabular}

Valores em R\$ milhão

Fonte: BACEN

Com base nas informações de patrimônio líquido e de lucro líquido é possível estimar o retorno sobre o patrimônio (Tabela 8).

Tabela 8 - Retorno sobre o patrimônio de bancos constituídos entre 2005 e 2009

\begin{tabular}{|c|c|c|c|c|c|c|c|c|c|c|c|}
\hline \multirow{2}{*}{ Instituição } & \multicolumn{10}{|c|}{ Balanço } & \multirow{2}{*}{ Média } \\
\hline & jun/10 & $\operatorname{dez} / 10$ & jun/11 & $\mathrm{dez} / 11$ & jun/12 & $\operatorname{dez} / 12$ & jun/13 & $\operatorname{dez} / 13$ & jun/14 & $\operatorname{dez} / 14$ & \\
\hline Azteca do $\mathrm{Br}$ & 4,96 & $-7,75$ & $-15,76$ & $-13,43$ & 1,54 & $-0,12$ & 3,71 & $-2,40$ & 3,79 & $-1,44$ & $-2,69$ \\
\hline Bco da China & 1,94 & 0,96 & 1,08 & $-0,18$ & 1,33 & $-10,45$ & $-1,40$ & $-19,61$ & 3,15 & $-28,53$ & $-5,17$ \\
\hline Caixa Geral Br & 2,72 & & 4,20 & 4,35 & 2,86 & & $-4,11$ & $-19,48$ & $-3,05$ & $-21,60$ & $-4,26$ \\
\hline Concórdia & $-5,85$ & & & & & & & & & & $-5,85$ \\
\hline Gerador & 3,53 & $-1,32$ & 6,96 & $-4,69$ & $-5,40$ & $-14,32$ & $-18,21$ & $-39,93$ & $-49,61$ & $-49,24$ & $-17,22$ \\
\hline JBS Banco & 4,27 & 1,90 & 10,18 & 19,42 & 18,71 & $-1,72$ & 2,75 & 4,02 & 2,39 & 4,88 & 6,68 \\
\hline Moneo & 21,14 & 15,93 & 18,65 & 14,07 & 13,33 & 17,79 & 10,51 & 5,82 & 1,81 & 15,87 & 13,49 \\
\hline Natixis Brasil & 1,84 & 5,42 & 4,34 & 7,59 & 6,47 & 4,37 & 8,70 & 12,81 & 6,52 & 13,29 & 7,14 \\
\hline Randon & & $-8,33$ & $-8,33$ & $-1,24$ & $-1,39$ & 2,44 & 4,07 & 6,54 & 9,51 & 7,33 & 1,18 \\
\hline Scania & $-4,92$ & $-0,88$ & 1,04 & $-0,28$ & $-4,31$ & $-4,58$ & & $-1,39$ & 18,79 & 2,02 & 0,61 \\
\hline Yamaha Motor & $-23,77$ & $-6,72$ & 1,89 & 47,49 & 4,72 & 17,47 & 19,37 & 20,27 & 9,66 & 37,33 & 12,77 \\
\hline
\end{tabular}

Valores em $\%$ a.a.

Fonte: o Autor, com base em dados do BACEN. 
Pode-se observar que:

- Se considerado um custo de capital próprio de 16,35\% a.a. (vide seção 5.6 .5 página 119), conclui-se que apenas o Banco Moneo e Banco Yamaha Motors têm apresentado retorno compatível. Ambas as instituições estão inseridas em grupos econômicos do setor automotivo, respectivamente Marco Polo e Yamaha. Curiosamente, o Banco Randon e Banco Scania pertencem a grupos econômicos do mesmo setor e apresentam ROE médio próximo a zero.

- O Banco Natixis Brasil, pertencente a um conglomerado financeiro francês, e o JBS Banco (atual Banco Original) apresentam ROE médio em torno dos 7\%, inferior, portanto, ao custo de capital.

- Os demais bancos têm apresentado ROE médio negativo.

O Gráfico 6 o eixo das abcissas refere-se ao patrimônio líquido médio no período analisado, em escala logarítmica, e o eixo das coordenadas ao retorno sobre o patrimônio médio, no mesmo período. Nota-se que não existe proporcionalidade entre as variáveis.

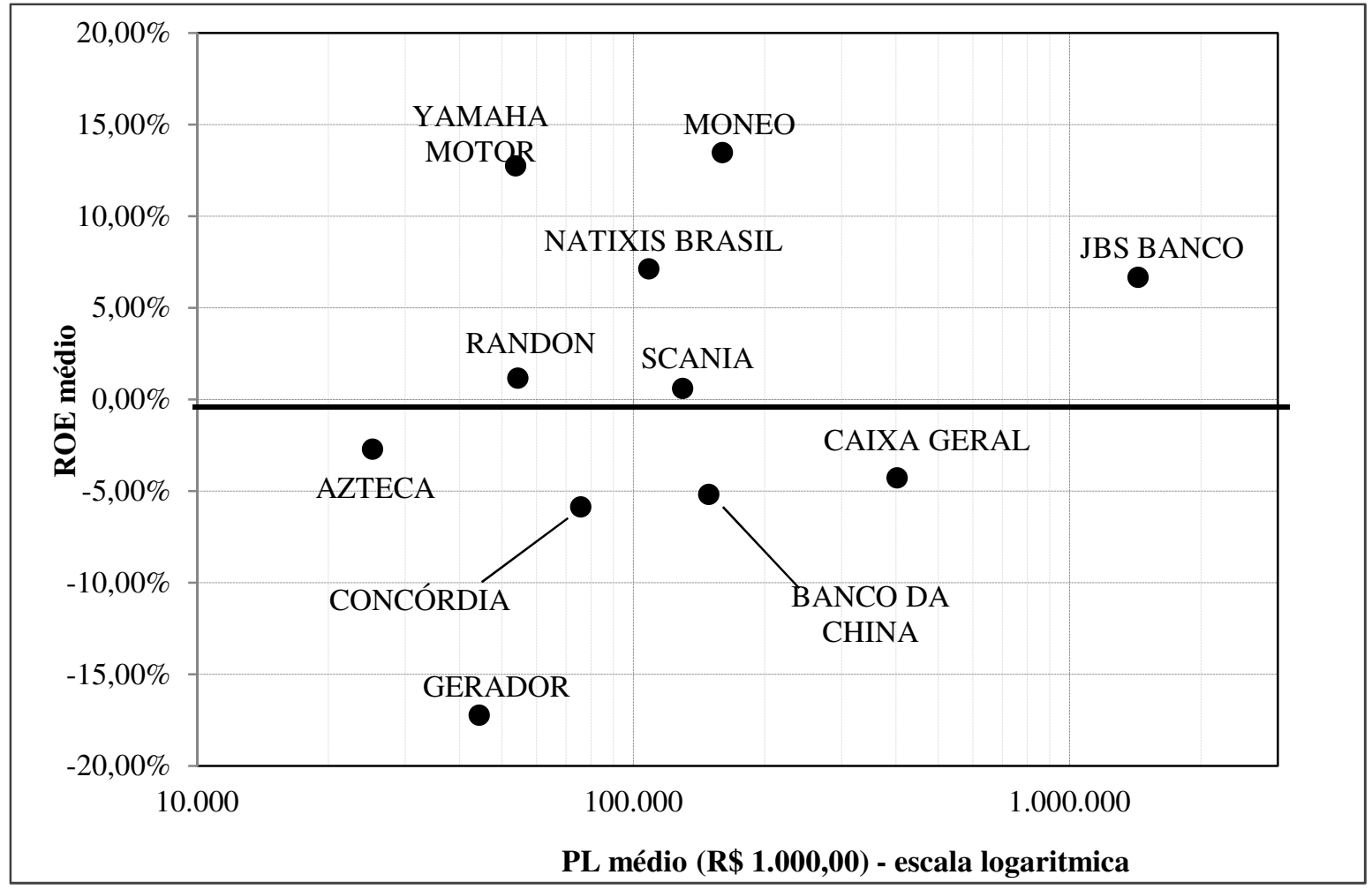

Gráfico 6 - Bancos recém-constituídos: ROE x Patrimônio Líquido 
Pode-se pensar que, sob a ótica do BACEN, o baixo retorno seja um problema que compete apenas ao acionista. Ledo engano. Uma instituição historicamente incapaz de oferecer retornos compatíveis com o risco não oferecerá qualquer atrativo para que o investidor integralize mais capital no momento em que o BACEN o vier a exigir, visando, por exemplo, a cobertura de eventuais prejuízos.

O baixo retorno das instituições recém constituídas deve suscitar o pensamento de que não apenas a dimensão mínima é importante, dada as questões de escala, mas também requer-se uma supervisão bancária mais efetiva no que tange ao cumprimento dos planos de negócio elaborados visando a aprovação das instituições; uma análise criteriosa quanto à exiguidade dos meios considerados no plano para viabilizá-la; e uma projeção de receitas e despesas financeiras realistas, condizentes com o riscos dos ativos e da própria instituição. 


\section{METODOLOGIA DE ANÁLISE}

\subsection{Aspectos gerais}

O problema de pesquisa será respondido pela estimação do valor do capital próprio que permita a contratação de carteira de ativos suficientes para suportar a estrutura de custos, compreendendo o quadro de funcionários e demais meios para o desempenho da atividade financeira; e oferecer ao acionista um retorno compatível com suas expectativas. Trata-se, portanto, da estimativa da escala mínima da instituição.

A questão da escala assume papel importante à medida que o custo de observância da atividade bancária tem crescido ao longo dos anos. $\mathrm{O}$ aprimoramento do processo de supervisão bancária, o reporte das informações pelas instituições ao BACEN, e as estruturas de controles de risco tem sido fundamentais para garantir a saúde do SFN. Por outro lado, estes fatores fazem com que o custo administrativo das instituições cresça. Quanto maior o porte da instituição financeira, maior será a dimensão de sua carteira de ativos, e melhores deverão ser as condições de diluição desses custos.

Por esta razão, deve haver um porte mínimo abaixo do qual as instituições não consigam remunerar o acionista dentro de sua expectativa, que é o custo de capital próprio, indicado por $\mathrm{K}_{\mathrm{E}}$. Sob a ótica do regulador, a importância do $\mathrm{K}_{\mathrm{E}}$ como referencial para a viabilidade econômica de instituições financeiras decorre do fato de que poderão ocorrer situações em que o BACEN venha a exigir a elevação de seu capital. São exemplos destas situações: prejuízos decorrentes do não pagamento de operações de crédito, prejuízos decorrente de perdas no valor das carteiras de títulos, prejuízos com derivativos, etc. Se a expectativa do investidor quando ao retorno não é atendida, ele não terá estímulo para realizar aportes de capital.

Desta forma, o problema se resume à obtenção de uma curva representativa do retorno sobre o patrimônio das instituições em função do porte, definido como o patrimônio líquido. A intersecção desta com a curva representativa do custo de capital define a dimensão a partir da qual o ROE supera o $\mathrm{K}_{\mathrm{E}}$, sendo este o valor mínimo adequado. 
Esta análise abrangeu os bancos comerciais ou bancos múltiplos com carteira comercial, os bancos de investimento ou múltiplos com carteira de investimento, as financeiras e as sociedades de crédito imobiliário. Estas quatro tipologias apresentam características distintas em termos de mercado alvo e perfil de ativos e passivos, que serão explicadas a seguir:

a) Os bancos comerciais estão habilitados a captar recursos em depósito à vista, possuem rede de agências e são detentores de conta reserva bancária, o que lhes dá condições de oferecer uma série de serviços financeiros, como repasse de arrecadações, transferência de fundos, cobrança, etc. Logo, uma parte nada desprezível de seu resultado é proveniente da receita financeira decorrente de floats e de tarifas. O aumento das taxas de juros lhes proporciona melhor remuneração dos recursos não onerosos. Seu mercado alvo é amplo, abrangendo tanto o varejo como o atacado.

b) Os bancos de investimento são instituições cujo mercado alvo é composto pelas grandes corporações e sua especialidade são as transações do mercado de capitais. Em geral, não possuem conta de reserva bancária ${ }^{4}$ e, a possibilidade de auferir receitas com floats é reduzida.

c) As financeiras, ou sociedades de crédito financiamento e investimento, são instituições voltadas para o financiamento ao consumo e capital de giro. Seu principal mercado alvo é o varejo. As financeiras não possuem conta de reserva bancária ${ }^{5}$, o que limita a possibilidade de auferir ganhos com floats. Pelo perfil de mercado alvo, a taxa média dos ativos das financeiras é alta.

d) As sociedades de crédito imobiliário são instituições especializadas no financiamento imobiliário. Estas operações contam com a colaterização dos ativos que financiam. Pelo menor risco e pela existência de políticas públicas de financiamento habitacional, a taxa média dos ativos deve ser baixa. Parte significativa de seus recursos é proveniente de cadernetas de poupança, o que lhes confere menor custo de captação.

\footnotetext{
${ }^{4}$ Com a reformulação do Sistema de Pagamentos Brasileiro (SPB) em 2002 foi facultado aos bancos e investimento a abertura de contas de reserva bancária no BACEN.

${ }^{5}$ O BACEN facultou às instituições não bancárias a abertura de conta de liquidação, que ao final do dia devem transferir seu saldo para uma instituição detentora de conta de reservas bancárias.
} 
Desta forma, torna-se fundamental que a análise da questão de pesquisa não considere conjuntamente as diferentes modalidades de instituição, dada as diferenças de perfil.

\subsection{Fontes de dados}

As informações e dados utilizados neste trabalho provêm de fontes secundárias. As fontes estão especificadas no Quadro 5.

Quadro 5 - Lista de fontes de informação e dados

\begin{tabular}{ll}
\hline Item & Fonte \\
\hline Artigos, teses, dissertações e livros & Diversas \\
Normas do SFN & BACEN \\
Informações contábeis das instituições financeiras & BACEN \\
Taxa de inflação brasileira (IPCA) & Instituto de Pesquisas Econômicas Avançadas - IPEA \\
Taxa de inflação americana (CPI) & U.S. Bureau of Labor Statistics \\
Taxa de juros no mercado americano & US Department of The Treasury \\
Taxa de risco Brasil - EMBI + Brazil & Instituto de Pesquisas Econômicas Avançadas - IPEA \\
\hline
\end{tabular}

\subsection{Instituições financeiras integrantes da amostra}

A Tabela 9 apresenta o número de instituições e o número de balanços existentes nos relatórios obtidos junto ao BACEN, e que servirão de ponto de partida para a estruturação do banco de dados utilizados nesta tese.

Tabela 9 - Número de instituições contidas nos arquivos

\begin{tabular}{lcc}
\hline \multicolumn{1}{c}{ Tipologia } & $\mathbf{N}^{\mathbf{0}}$ de Instituições & $\begin{array}{c}\mathbf{N}^{\mathbf{0}} \text { de demonstrativos } \\
\text { financeiros }\end{array}$ \\
\hline Banco Comercial $(* 1)$ & 109 & 949 \\
Banco de Investimento $(* 2)$ & 35 & 317 \\
Banco de Desenvolvimento & 4 & 40 \\
Banco de Câmbio & 3 & 15 \\
Financeira & 47 & 308 \\
Crédito Imobiliário & 12 & 70 \\
Companhias Hipotecárias & 5 & 27 \\
Arrendamento Mercantil & 6 & 35 \\
\hline Total Geral & 221 & 1.761 \\
\hline
\end{tabular}

(*1) Bancos comerciais ou múltiplos com carteira comercial

(*2) Bancos de investimento ou múltiplos sem carteira comercial 
A análise realizada abrangerá os bancos comerciais ou múltiplos com carteira comercial, os bancos de investimento ou múltiplos com carteira de investimento, as financeiras, as sociedades de crédito imobiliário e as companhias hipotecárias, relacionadas no Relatório dos 50 maiores Bancos, do BACEN.

As companhias hipotecárias foram reclassificadas como sociedades de crédito imobiliário devido ao pequeno número de empresas. Esta reclassificação é razoável visto que ambas as modalidades de companhia financiam o mesmo setor e, por conseguinte, competem entre si. Esta reclassificação irá dar maior consistência às estatísticas das sociedades de crédito imobiliário, em vista da elevação do número de empresas assim classificadas.

Não foram abrangidos na análise e, portanto, foram excluídos da base de dados:

- Os bancos de câmbio, visto que o pequeno número de instituições existentes não produziria estatísticas confiáveis.

- Os bancos de desenvolvimento (BNDES, BRDE, BANDES e BDMG), que têm como principal missão fomentar o desenvolvimento econômico regional. Desta forma, as taxas de juros cobradas nas operações de crédito podem embutir certo nível de subsídio. Além disso, quatro instituições apenas não forneceriam estatísticas confiáveis.

- As sociedades de arrendamento mercantil. Apurou-se que estas companhias, em sua maioria, são subsidiárias de companhias estrangeiras especializadas em leasing operacional. Constatou-se que estas companhias possuíam receitas e despesas de intermediação desproporcionais, que produziriam taxas médias de aplicação e captação capazes de distorcer estas estatísticas.

- As instituições que sofreram liquidação extrajudicial ao longo do período analisado. Esta providência visa manter a coerência com o objetivo do trabalho, que é estudar a viabilidade das instituições. Evidentemente, aquelas que foram liquidadas mostraram-se inviáveis, por uma razão ou outra. Foram excluídos, por esse critério, cinco bancos, uma financeira, uma companhia de crédito imobiliário e uma companhia hipotecária. 
- As instituições consideradas inativas. Enquadram-se nesta situação um banco, uma financeira e duas sociedades de crédito imobiliário. Estas instituições apresentam carteiras de crédito residuais, não possuem depósitos e as despesas administrativas são claramente de subsistência, evidenciando que suas estruturas foram desmontadas e elas permanecem abertas apenas em função de estoques remanescentes de operações de crédito.

- Instituições com perfil atípico. Enquadra-se nesta situação o Banco BM\&FBOVESPA, criado com o propósito de viabilizar as operações daquela bolsa, como custódia, e liquidação de operações. Este banco não possui carteira de crédito e apresenta nível de alavancagem baixíssimo, o que iria comprometer as estatísticas estudadas.

No caso de fusões de instituições, as denominações originais foram mantidas. Desta forma, preservaram-se os dados do Banco JBS e do Banco Matone, que se fundiram para formar o Banco Original. Estas três instituições constam na base de dados. Da mesma forma, preservou-se a identidade do Banco CR2, adquirido pelo ABN AMRO Bank. A razão disso foi o expressivo aumento dos números contábeis, fruto do escopo de negócio estabelecido pela nova administração. Nesse caso em particular, o BACEN havia mantido o mesmo código identificador.

A Tabela 10 apresenta o número de instituições e registro, após as exclusões e reclassificações e a Tabela 11 o número de instituições presentes em cada semestre.

Tabela 10 - Número de instituições selecionadas

\begin{tabular}{lcc}
\hline Tipologia & $\mathbf{N}^{\mathbf{0}}$ de Instituições & $\begin{array}{c}\mathbf{N}^{\mathbf{0}} \text { de demonstrativos } \\
\text { financeiros }\end{array}$ \\
\hline Banco Comercial & 102 & 920 \\
Banco de Investimento & 35 & 317 \\
Financeira & 45 & 299 \\
Crédito Imobiliário & 13 & 80 \\
\hline Total Geral & 195 & 1616 \\
\hline
\end{tabular}


Tabela 11 - Número de instituições por semestre

\begin{tabular}{cccccc}
\hline Semestre & Balanço & $\begin{array}{c}\text { Banco } \\
\text { Comercial }\end{array}$ & $\begin{array}{c}\text { Banco de } \\
\text { Investimento }\end{array}$ & $\begin{array}{c}\text { Crédito } \\
\text { Imobiliário }\end{array}$ & Financeira \\
\hline 1 & Jun/2010 & 90 & 30 & 0 & 0 \\
2 & Dez/2010 & 91 & 30 & 0 & 0 \\
3 & Jun/2011 & 90 & 33 & 12 & 36 \\
4 & Dez/2011 & 91 & 33 & 12 & 38 \\
5 & Jun/2012 & 92 & 32 & 10 & 38 \\
6 & Dez/2012 & 94 & 32 & 9 & 36 \\
7 & Jun/2013 & 91 & 30 & 10 & 35 \\
8 & Dez/2010 & 93 & 32 & 9 & 38 \\
9 & Jun/2014 & 94 & 32 & 10 & 39 \\
10 & Dez/2014 & 94 & 33 & 8 & 39 \\
\hline
\end{tabular}

\subsection{Informações contábeis das instituições financeiras}

As informações contábeis das instituições foram obtidas no relatório dos $\mathbf{5 0}$ maiores bancos e o consolidado do Sistema Financeiro Nacional, no sítio do BACEN (Relatório Top 50), no qual são apresentados os saldos contábeis trimestrais por instituição. Foram escolhidos apenas os dados referentes ao encerramento de cada semestre. As informações obtidas abrangem os anos de 2010 a 2014. Desta forma, o banco de dados gerado contém informações de 10 semestres. As informações das financeiras, das sociedades de arrendamento mercantil, de crédito imobiliário e hipotecário, passaram a constar no relatório Top 50 a partir de junho de 2011, o que limita as informações destas companhias a 7 semestres.

Os campos que compõem os registros do relatório Top 50 são apresentados no Quadro 6.

Quadro 6 - Estrutura do relatório Top 50 do BACEN

\begin{tabular}{cl}
\hline Linha & Campo \\
\hline 1 & CI $(* 1)$ \\
2 & TCB $(* 2)$ \\
3 & Instituições \\
4 & TD $(* 3)$ \\
5 & TC $(* 4)$ \\
6 & Obs. \\
\hline
\end{tabular}




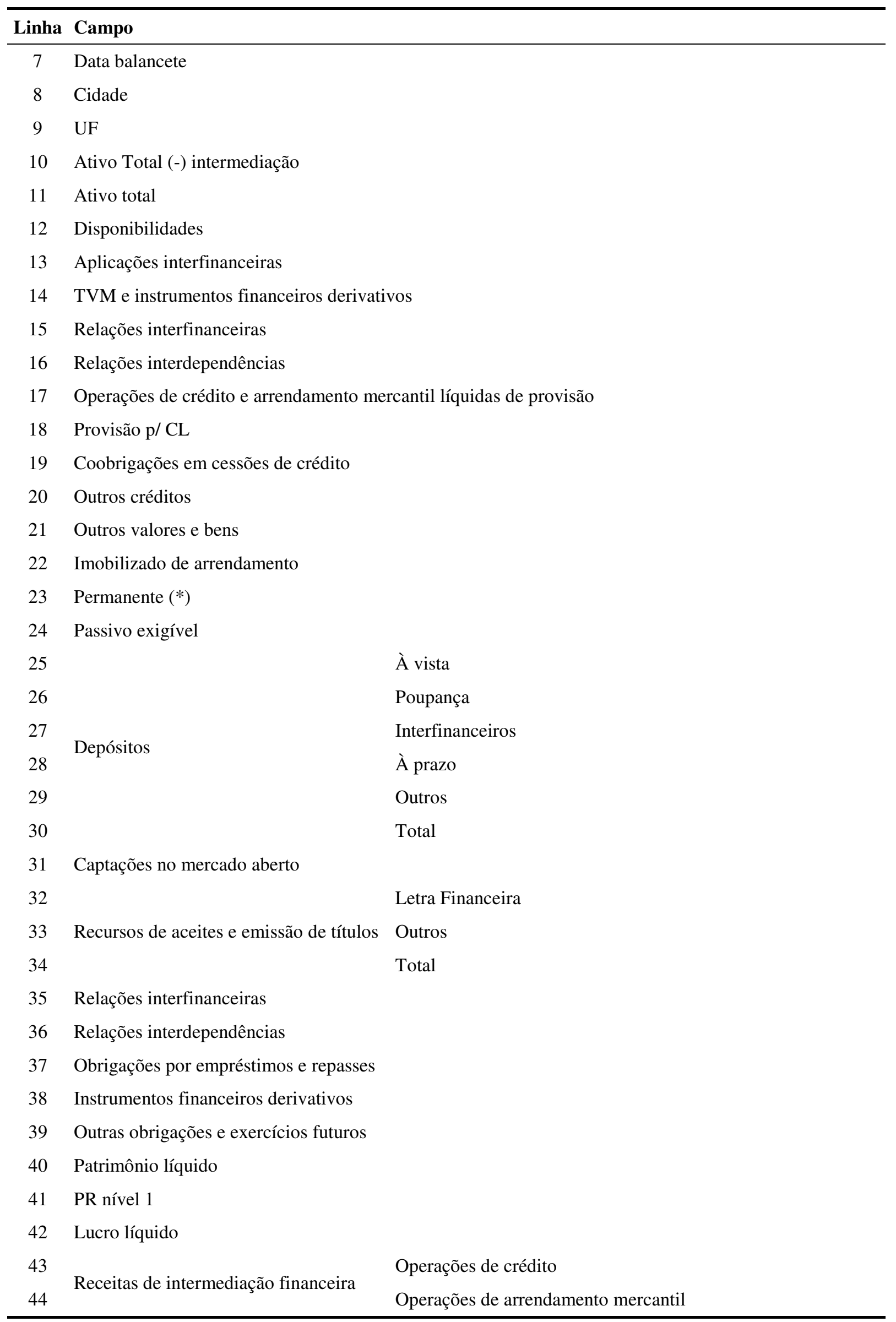




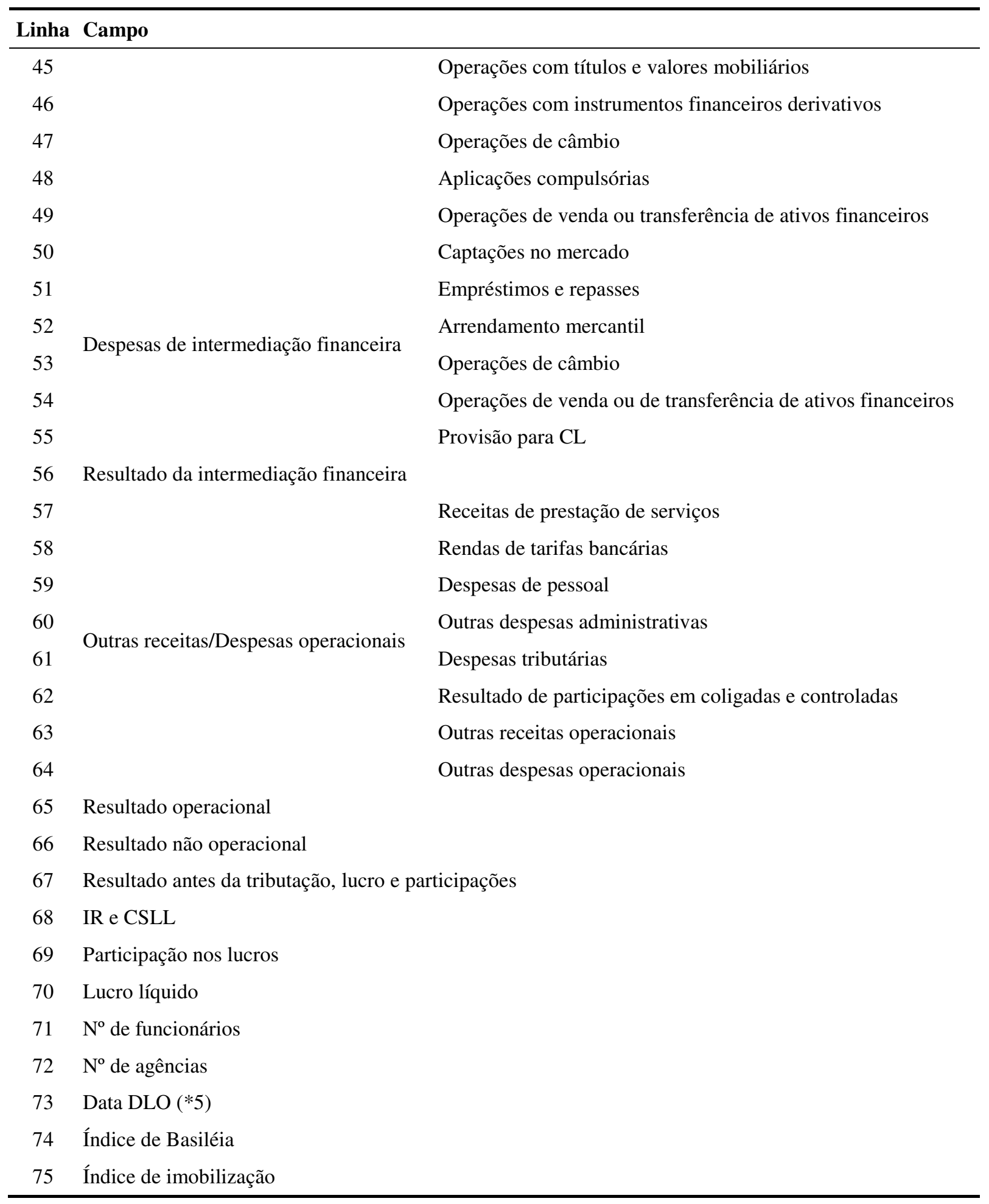

Notas:

(*1) Identificador do BACEN ou o CNPJ da instituição.

(*2) Tipo de consolidado bancário.

(*3) Tipo de documento: I - Independente; C - Conglomerado.

(*4) Tipo de controle: 1-Público; 2 - Privado Nacional; e 3 - Privado com Controle Estrangeiro.

(*5) Data dos Limites Operacionais

Fonte: Bacen 


\subsection{Tratamento geral dado às informações}

O banco de dados criado consolidou 10 arquivos do BACEN; desta forma, é natural a existência de inconsistências, do tipo:

- Diferenças quanto aos campos dos relatórios;

- Variação na grafia do nome da instituição entre diferentes relatórios;

- Erros eventuais na atribuição do tipo de consolidado bancário;

- Mais de um código de identificação para o mesmo nome de instituição.

Esses dados foram uniformizados com base nas informações mais recentes. Para tanto foi consultada a página de informações cadastrais e contábeis, no sítio do BACEN para dirimir eventuais dúvidas.

Alguns registros dos arquivos obtidos junto ao BACEN traziam informações financeiras de meses diferentes de junho e dezembro. Uma vez que serão calculadas as taxas médias de aplicação e captação, a inclusão desses demonstrativos, por considerarem um número de meses inferior ao semestre, poderia enviesar o resultado final, para o que foram excluídos.

O Anexo 1 apresenta o número de balanços, por instituição, que compõem a base de dados.

\subsection{Atualização monetária dos valores}

Tendo em vista o ambiente inflacionário brasileiro, os valores contábeis foram corrigidos para dezembro de 2014. O índice de inflação utilizado para esta finalidade foi o IPCA.

\subsection{Custo de Capital Próprio}

$\mathrm{O}$ custo de capital próprio $\left(\mathrm{K}_{\mathrm{E}}\right)$ será estimado por meio de dois modelos, visando a obtenção de convergência para um determinado valor. Estes modelos são o CAPM de Sharpe (1964) e 
uma variante sua, o International Asset Pricing Model (IAPM) de Solnik (1974). O CAPM de Sharpe pode ser expresso pela equação (1).

$$
E\left(r_{i}^{k}\right)_{C A P M}=r_{f}^{k}+\beta_{i}^{k}\left(E\left(r_{m}^{k}\right)-r_{f}^{k}\right)
$$

Onde:

$E\left(r_{i}^{k}\right)_{C A P M}$ é a expectativa de retorno do ativo i negociado na bolsa k

$E\left(r_{m}^{k}\right)$ é a expectativa de retorno do mercado $\mathrm{k}$

$r_{f}^{k}$ é o retorno do ativo livre de risco no mercado $\mathrm{k}$

$E\left(r_{m}^{k}\right)-r_{f}^{k}$ é o prêmio de risco do mercado k

$\beta_{i}^{k}$ é o beta do ativo i com relação ao índice $\mathrm{k}$.

O termo $E\left(r_{i}^{k}\right)_{C A P M}$ é expresso em reais nominais e não requer nenhum ajuste, para sua comparação com o ROE das instituições financeiras.

O custo de capital próprio estimado pelo IAPM parte de premissas semelhantes ao CAPM, e adicionalmente considera a inexistência de barreiras ao fluxo de capital, a negociação contínua de títulos e moedas, um regime de câmbio flexível, e que o consumo dos investidores é limitado ao mercado doméstico (Solnik, 74).

Em Solnik (1974), Adler e Solnik (1974) e Copeland et al (2005, p. 846), a expectativa de retorno do ativo, pelo IAPM, é dado pela equação (2):

$$
E\left(r_{i}^{k}\right)_{I A P M}=r_{f}^{k}+\beta_{i}^{G L}\left(E\left(r_{m}^{G L}\right)-r_{f}^{G L}\right)
$$

Em que:

$E\left(r_{i}^{k}\right)$ é a expectativa de retorno do ativo i, negociado na bolsa $\mathrm{k}$, na moeda local. $E\left(r_{m}^{G L}\right)$ é a expectativa de retorno do mercado global

$r_{f}^{G L}$ é o retorno do ativo livre de risco global

$r_{f}^{k}$ é o retorno do ativo livre de risco do mercado local

$E\left(r_{m}^{G L}\right)-r_{f}^{G L}$ é o prêmio de risco do mercado global

$\beta_{k}^{G L}$ é o beta do ativo i com relação ao mercado global

Solnik (1974) justifica seu modelo enunciando o seu Teorema 3, no qual o prêmio de risco de um título sobre a taxa livre de risco doméstica é proporcional ao prêmio de risco do mercado global sobre o retorno médio de títulos internacionais. Para tanto, Solnik (1974) considera que os investidores sempre podem fazer hedge de suas exposições cambiais, o que faz com que apenas a taxa de juros seja relevante ao se apreçar o risco de mercado. 
Copeland et al (2005, p. 855) lembram ainda que o beta de um título relativamente ao mercado global ( $\left.\beta_{i}^{G L}\right)$ corresponde ao produto de seu beta doméstico $\left(\beta_{i}^{k}\right)$ pela sensibilidade entre o mercado doméstico e o mercado local $\left(\beta_{k}^{G L}\right)$. Observação semelhante é feita por Adler e Solnik (1974, p. 371), segundo os quais o risco sistemático internacional de um ativo é igual ao produto do risco sistemático nacional desse ativo pelo risco sistemático internacional do país em questão. Assim, a equação (2) pode ser reescrita:

$$
E\left(r_{i}^{k}\right)_{I A P M}=r_{f}^{k}+\beta_{i}^{k} \beta_{k}^{G L}\left(E\left(r_{m}^{G L}\right)-r_{f}^{G L}\right)
$$

É importante mencionar que a taxa livre de risco do mercado local embute no seu cômputo o risco país e a perspectiva de inflação local. Desta forma, o modelo de Solnik, como concebido, fornece a expectativa de retorno de um ativo sem que se faça necessário ajustes para o risco país e para o diferencial entre as inflações do mercado local e do mercado global. O termo $E\left(r_{i}^{k}\right)_{I A P M}$ portanto, também é expresso em reais nominais e diretamente comparável ao ROE das instituições financeiras.

A especificação das variáveis é dada no Quadro 7.

Quadro 7 - Variáveis para o cálculo do custo de capital próprio $\left(K_{E}\right)$

\begin{tabular}{|c|l|c|}
\hline Variável & \multicolumn{1}{|c|}{ Descrição / Parâmetro adotado } & Período considerado \\
\hline$r_{f}^{k}$ & $\begin{array}{l}\text { Taxa livre de risco brasileira, medida a partir da taxa de 2 } \\
\text { anos, extraída de uma estrutura a terno de taxas de juros, } \\
\text { construída a partir da média entre taxa de compra e taxa } \\
\text { de venda de Letras do tesouro Nacional, obtidas nas } \\
\text { estatísticas do Tesouro Direto. }\end{array}$ & Jan/ 2010 a Dez/2014 \\
\hline$r_{f}^{G L}$ & $\begin{array}{l}\text { Taxa de 10 anos obtida a partir de uma yield curve de } \\
\text { Treasury Bills \& Bonds do Tesouro Americano. }\end{array}$ & Jan/ 2010 a Dez/2014 \\
\hline$E\left(r_{m}^{k}\right)-r_{f}^{k}$ & $\begin{array}{l}\text { Prêmio de risco do mercado brasileiro. Obtido com base } \\
\text { em dados históricos ou com base nas pesquisas de } \\
\text { Fernandez et al }\left(2010,2011,2013^{\mathrm{a}}, 2013 \mathrm{~b}, 2014\right) .\end{array}$ & Jan/1995 a Dez/2014 \\
\hline$E\left(r_{m}^{G L}\right)-r_{f}^{G L}$ & $\begin{array}{l}\text { Prêmio de risco do mercado americano. Obtido com base } \\
\text { em dados históricos ou com base nas pesquisas de } \\
\text { Fernandez et al }\left(2010,2011,2013^{\mathrm{a}} \text {, 2013b, 2014). }\right.\end{array}$ & Jan/1990 a Dez/2014 \\
\hline$\beta_{i}^{k}$ & $\begin{array}{l}\text { Beta de uma carteira teórica de ações de bancos } \\
\text { brasileiros, tendo o Índice Bovespa como regressor. }\end{array}$ & Jan/2005 a Dez/2014 \\
\hline$\beta_{k}^{G L}$ & Beta do IBOVESPA, regredido pelo S\&P500 & Jan/1995 a Dez/2014 \\
\hline
\end{tabular}

Verificou-se também a existência de variações do IAPM, como aquele modelo empregado por 
algumas agências reguladoras, como a ANATEL (2009) e ARSESP (2011). Este modelo emprega como primeiro termo a taxa livre de risco do mercado global $\left(r_{f}^{G L}\right)$, ao invés da taxa do mercado local $\left(r_{f}^{k}\right)$ e considera ainda um adicional para risco Brasil (EMBI+BR). Desta forma, esse modelo fornece uma expectativa de retorno em dólares nominais, e seu resultado deve ser deflacionado pela inflação americana, e inflacionado pela inflação brasileira.

Será considerado o efeito tamanho (size effect), estudado por Banz (1981) e posteriormente por Fama e French (1992). A estimação do efeito tamanho irá se basear em uma regressão tendo como variável dependente o retorno de bancos brasileiros; e como variável independente o seu patrimônio líquido, na forma de logaritmo natural. A declividade resultante irá definir a curva do custo de capital, tal que:

$$
\pi_{i}=\theta P L_{i}
$$

Onde:

$\pi_{i}$ é o size premium do ativo índice $\mathrm{i}$

$\theta$ é o coeficiente entre o prêmio e o patrimônio líquido do ativo i

$P L_{i}$ é o logaritmo natural do valor do patrimônio líquido do ativo i.

Assim, a equação do custo de capital irá incorporar um termo relativo ao porte da instituição, como apresentado na equação (5), em que $K_{E i}$ é o custo de capital próprio do i-ésimo ativo.

$$
K_{E_{i}}=K_{E}+\pi_{i}
$$

Optou-se pelo uso do valor contábil do patrimônio líquido como medida de tamanho, diferentemente de Fama e French (1992), que utilizaram seu valor de mercado. Esta opção deve-se ao fato de que todo o modelo construído basear-se no valor do patrimônio líquido. $\mathrm{O}$ uso do valor contábil como indicador de tamanho já havia ocorrido nos trabalhos de Stattman (1980, apud FAMA; FRENCH, 1992) e Rosenberg, Reid, e Lanstein (1985, apud FAMA; FRENCH, 1992).

A Ilustração 1 apresenta as possíveis relações entre o Custo de Capital Próprio $\left(\mathrm{K}_{\mathrm{E}}\right)$ e o Patrimônio Líquido (PL), que poderão resultar de uma regressão em que o ROE é a variável independente e o retorno de mercado e o patrimônio líquido são as variáveis explicativas. Espera-se que $\mathrm{K}_{\mathrm{E}}$ seja inversamente proporcional ao patrimônio líquido (Situação 1). 


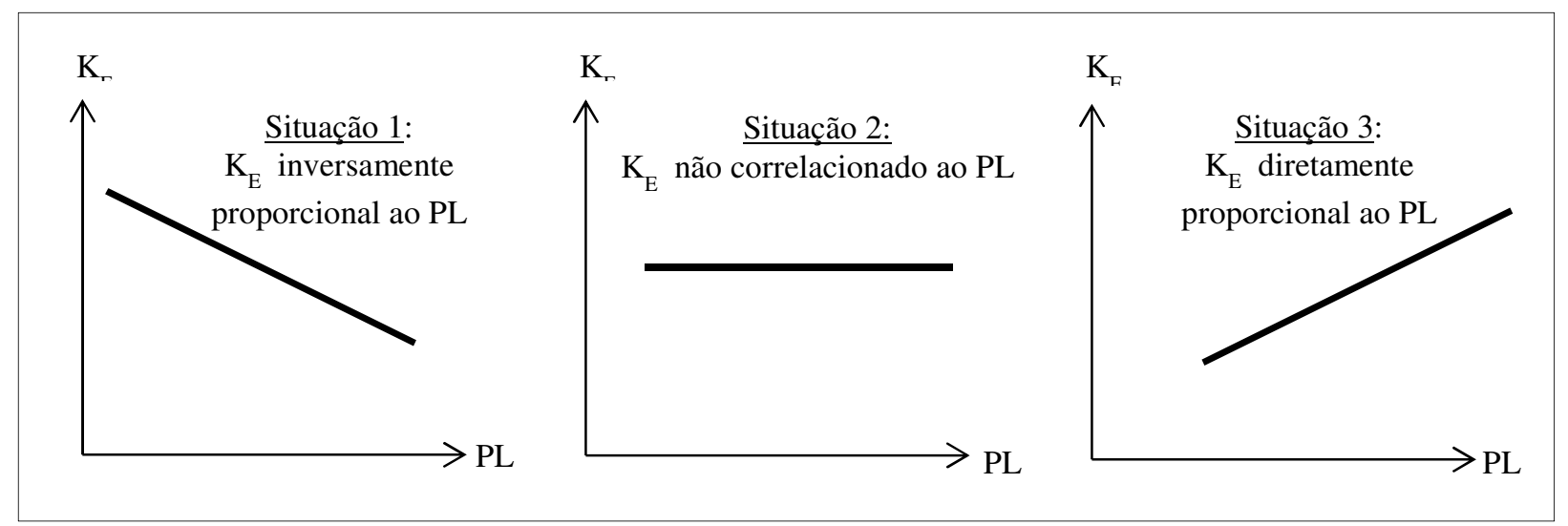

Ilustração 1 - Possíveis relações entre $K_{E}$ e PL

Não serão considerados os riscos não diversificáveis.

\subsection{Estatísticas descritivas}

Com vistas à realização de uma análise exploratória dos dados, será realizada uma análise descritiva, com a apuração dos principais parâmetros estatísticos. Para Fávero et al (2009), a estatística descritiva "permite ao pesquisador uma melhor compreensão do comportamento dos dados".

Esta análise irá se basear em variáveis relativas, em que se divide uma dada dimensão monetária, como por exemplo, o ativo imobilizado, por outra dimensão monetária que caracterize o porte da instituição, como o valor do patrimônio líquido ou do ativo total.

Esta análise irá agrupar os dados de acordo com:

- A modalidade das instituições financeiras analisadas;

- O momento no tempo a que os números se referem;

- O porte das instituições.

O agrupamento pela modalidade, isto é, pela tipologia da instituição, é fundamental para que se verifiquem as discrepâncias das variáveis estudadas decorrentes dos diferentes modelos de 
negócio financeiro. É razoável se esperar, por exemplo, que as taxas médias de aplicação das financeiras sejam sensivelmente superiores às taxas praticadas pelas sociedades de crédito imobiliário, haja vista o mercado alvo a que estas instituições estão direcionadas.

O agrupamento temporal, isto é, pelo semestre a que os demonstrativos financeiros se referem, tem como objetivo identificar se as relações entre as variáveis guardam alguma estabilidade no período analisado. Esta análise será realizada para cada uma das modalidades de instituição financeira.

O agrupamento pelo porte tem como objetivo identificar se as relações entre as variáveis se mantêm constantes, independentemente do porte da instituição. Esta análise também irá considerar a tipologia. Para sua realização, os dados serão agrupados em clusters definidos pelo patrimônio líquido da instituição. A metodologia utilizada é descrita em 4.8.2.

\subsubsection{Testes estatísticos}

As estatísticas descritivas agrupadas por tipologia e pelo porte das instituições irão fornecer informações relevantes, que darão um bom indicativo para a melhor compreensão de suas características. No entanto, qualquer comparativo entre essas estatísticas irá requerer a verificação da existência de significância das diferenças observadas. Assim, as médias obtidas por agrupamento serão testadas entre si.

O teste de médias será realizado por ANOVA - Analysis of Variance; no entanto, o método impõe a normalidade da variável (HAIR JR. et al, 2009, p. 82, 321-322; FÁVERO et al, 2009, p. 474). A verificação da normalidade dos dados utilizará o teste de KolmogorovSmirnov; se rejeitada a hipótese de normalidade, a igualdade de médias será verificada pelo teste de Kruscal-Wallis.

\subsubsection{Análise de conglomerados}

Com o intuito de realizar uma primeira análise dos efeitos do porte da instituição sobre algumas variáveis estudadas, as instituições serão classificadas em conglomerados (clusters). Será utilizado como variável dimensão o valor do patrimônio líquido. Tendo em vista que as 
distâncias entre os maiores bancos poderiam fazer com que todas as instituições de pequeno e médio porte fossem alocadas em um único cluster, o patrimônio líquido será considerado na forma de logaritmo natural. Todas as instituições, independente de sua tipologia, serão classificadas conjuntamente. Isto permite o estabelecimento de comparativos, por exemplo, entre bancos e financeiras de porte semelhante. Os demonstrativos financeiros escolhidos para esta análise serão os de dezembro de 2014.

Inicialmente será realizada uma análise exploratória para definir o número de conglomerados, que se baseará em Clusters Hierárquicos, utilizando distâncias euclidianas. Serão comparados os métodos de agrupamentos between groups, centróide e Ward e a escolha recairá sobre o estágio imediatamente anterior àquele que apresentar uma grande variação do coeficiente de proximidade. Definido o número ideal de conglomerados, as instituições serão reclassificadas pelo método K-Médias.

\subsection{Modelo econométrico}

A questão de pesquisa foi respondida por meio da interseção de duas curvas. A primeira delas estabelece a relação entre o ROE e o porte da instituição; e a segunda a relação entre o custo de capital e o porte. Como variável determinante do porte adotou-se o patrimônio líquido. A interseção indica o valor do patrimônio liquido em que o ROE iguala-se ao custo de capital. Evidentemente, supõe-se que o ROE seja diretamente proporcional ao patrimônio líquido.

\subsubsection{Regressões explicativas do retorno sobre o patrimônio líquido}

Uma vez que os dados disponíveis referem-se a diferentes instituições em diferentes períodos, o modelo de regressão utilizado foi o de painel estático, com agrupamento por instituição e pelos semestres a que se referem os demonstrativos financeiros.

Foram testados os modelos de painel com agrupamento de dados - POOLS, com efeitos fixos e com efeitos aleatórios. A estimação por POOLS desconsidera o efeito longitudinal da base de dados, e considera um único cross sectional; sua solução, portanto, dá-se por MQO Mínimos Quadrados Ordinários (FÁVERO, 2015, p. 267). A estimação por POOLS pressupõe que os estimadores $\alpha$ e $\beta$ s são válidos para qualquer indivíduo (instituições 
financeiras no caso) e para qualquer ponto no tempo (FAVERO et al, 2009, p. 382).

A estimação por efeito fixo considera a existência de um fator não observável relacionado a cada indivíduo, constante ao longo do tempo (STOCK; WATSON, 2004, p.190), e correlacionadas com as variáveis explicativas (FÁVERO, 2015, p. 269; WOOLDRIDGE, 2012, p. 457). Nesta abordagem pressupõe-se que os estimadores $\beta$ s são válidos para todas as observações ao longo do tempo, mas $\alpha$ é individualizado (FAVERO et al, 2009, p. 382).

Na estimação por efeitos aleatórios a variação entre indivíduos é considerada aleatória e não correlacionada com as variáveis explicativas (FÁVERO, 2015, p. 269; WOOLDRIDGE, 2012, p. 457).

Todas as regressões consideraram erros-padrão robustos. Esta medida tem como objetivo descartar a hipótese de que a heterocedasticidade dos dados esteja resultando coeficientes viesados.

A escolha entre um ou outro modelo requereu o processamento de testes de Breusch-Pagan e de Hausman. O teste de Breusch-Pagan é utilizado para a escolha entre POOLS e efeitos aleatórios. A hipótese nula é que a variância entre os indivíduos é igual a zero, o que recomenda o uso de POOLS; em caso contrário, opta-se pelo modelo de painel com efeitos aleatórios (FÁVERO, 2015, p. 287).

O teste de Hausman é utilizado pela escolha entre efeitos fixos e aleatórios. A hipótese nula é que não existe correlação entre os efeitos individuais e as variáveis explicativas, isto é, os efeitos individuais são aleatórios. A confirmação de H0 recomenda a adoção de estimação por efeitos aleatórios; do contrário opta-se por efeitos fixos (FÁVERO, 2015, p. 288). Uma vez que se adotou erro padrão robusto, deve-se adotar a versão robusta do teste de Hausman, que é o teste de Schaffer e Stillman.

Uma vez que que não existem informações para todos os balanços semestrais de muitas instituições, as regressões configuraram um painel desequilibrado (STOCK; WATSON, 2004, p.186; WOOLDRIDGE, 2012, p.456 e 676).

O modelo de regressão que irá responder à questão de pesquisa é apresentado no Quadro 8. 
Quadro 8 - Regressão que irá responder à questão de pesquisa

Variável dependente: Retorno sobre o Patrimônio (ROE)

\begin{tabular}{|c|c|c|}
\hline Variáveis independentes & Sigla & Pressuposto \\
\hline $\begin{array}{l}\text { Logaritmo do patrimônio líquido } \\
\qquad(\mathrm{em} \mathrm{R} \$ 1.000,00)\end{array}$ & $l n \_p l$ & $\begin{array}{l}\text { Que o ROE diretamente correlacionado com o } \\
\text { porte da instituição. }\end{array}$ \\
\hline Alavancagem & alavanc & $\begin{array}{l}\text { Que o ROE cresce à medida que a instituição } \\
\text { aumenta seu nível de alavancagem bancária. }\end{array}$ \\
\hline Alavancagem $^{2}$ & alavanc $^{2}$ & $\begin{array}{l}\text { Que a partir de certo ponto a alavancagem } \\
\text { excessiva possa representar alguma fragilidade } \\
\text { que reduza o ROE da instituição }\end{array}$ \\
\hline Dummies de tempo & sem1-sem10 & $\begin{array}{l}\text { Inseridas com o objetivo de emular o cenário } \\
\text { econômico de cada semestre. }\end{array}$ \\
\hline
\end{tabular}

O Patrimônio Líquido, utilizado na forma logarítmica, é a principal variável explicativa do problema, ou seja, aquela sobre a qual se pretende responder à questão de pesquisa. No entanto, outras variáveis também podem contribuir para a explicação do retorno das instituições financeiras. São elas a alavancagem bancária e variáveis conjunturais.

A variável definida como alavancagem utilizada foge do conceito clássico utilizado na literatura de finanças e aproxima-se ao conceito de alavancagem bancária utilizada pelos reguladores financeiros. Esta variável foi definida como o percentual do capital regulatório que foi utilizado pela estrutura de ativos da instituição e pelos riscos inerentes. Assim, quando uma instituição apresenta alavancagem igual a 0,5 significa que está utilizando a metade de seu capital regulatório, ou seja, ela tem a oportunidade de dobrar suas exposições a risco. O Índice de Basiléia utilizado para esta finalidade foi de $11 \%$, vigente entre 2010 e 2014.

A utilização da variável alavancagem elevada ao quadrado decorre da hipótese de que instituições utilizando a totalidade de seu capital regulatório tenham menor retorno do que instituições mais capitalizadas, que possuem excedente de capital regulatório. $\mathrm{Na}$ verdade, a maior alavancagem verificada no balanço de uma instituição pode não ser fruto de uma atuação comercial agressiva, e sim, o reflexo de prejuízos havidos em exercícios anteriores e da baixa capacidade da instituição de se capitalizar, o que suscita que estas instituições possam ser passivas no que concerne ao capital regulatório, isto é, a alavancagem é resultado de fatores exógenos, como prejuízos e incapacidade de capitalização, ao invés de uma decisão executiva de utilizar o capital regulatório ao máximo. É de se supor, portanto, que exista um 
ponto ótimo em termos de utilização do capital regulatório, em que o retorno seria máximo. Desta forma, espera-se que as variáveis alavanc e alavanc ${ }^{2}$ sejam, respectivamente, direta e indiretamente proporcionais à variável dependente ROE.

Não se pode desprezar o fato de que existem diversos fatores que explicam o ROE das instituições financeiras, dentre eles as variáveis conjunturais. Uma instituição de determinado porte poderá ser ou não viável em função do cenário econômico. Inúmeros podem ser estes fatores: taxa de juros, taxa de inadimplência, nível de atividade econômica, renda do trabalhador assalariado, desempenho das bolsas de valores, etc. Dois caminhos poderiam ser seguidos: (i) a inserção de variáveis explicativas do cenário econômico e (ii) a inserção de variáveis dummies relativas ao tempo. A primeira alternativa poderia requerer a inserção de um grande número de variáveis, e a explicação de seus efeitos seria muito complexa; desta forma, a alternativa escolhida foi a inserção de variáveis dummies representativas do semestre. Desta forma, quaisquer que fossem as variáveis econômicas que diferenciaram um semestre do outro, a estrutura de variáveis dummies estaria contemplando esses efeitos.

Serão inseridas 9 variáveis dummies, sendo a primeira relativa ao $1^{\circ}$ semestre de 2010 . O $2^{\circ}$ semestre de 2014 não terá variável dummy.

Em resumo, a regressão testada é dada pela equação (6).

$$
R O E=\alpha+\beta_{1} \ln \_p l+\beta_{2} \text { alavanc }+\beta_{3} \text { alavanc }^{2}+\theta_{1} \operatorname{sem} 1+\cdots+\theta_{9} \operatorname{sem} 9
$$

O ponto ótimo em termos de alavancagem pode ser obtido ao se igualar a zero a derivada da equação (6) por alavanc, tal como apresentado nas equações (7) e (8):

$$
\begin{gathered}
\frac{d R O E}{d \text { alavanc }}=\beta_{2}+2 \beta_{3} \text { alavanc }=0 \\
\text { alavanc }=\frac{\beta_{2}}{2 \beta_{3}}
\end{gathered}
$$

Preferiu-se não usar variáveis dummies para diferenciar a tipologia das instituições, visto que se faria necessário inserir também variáveis dummies de interação entre as variáveis independentes citadas e as quatro modalidades de instituições financeiras analisadas, o que 
traria uma desnecessária complexidade ao problema. Assim preferiu-se processar regressões independentes para cada modalidade de instituição financeira.

Testou-se se os resíduos das regressões respeitam à premissa de MQO de média condicional zero. Aplicou-se também sobre os resíduos o teste de Shapiro-Francia para normalidade, recomendado para grandes amostras (FÁVERO, 2015, p. 46). A necessidade de normalidade dos resíduos é amenizada por Wooldridge (2012, p. 152, 163-165), segundo o qual a violação desta premissa é minimizada quando da utilização de grandes amostras, devido às propriedades assintóticas dos estimadores por MQO.

Algumas instituições podem apresentar distorções, sistemáticas ou eventuais, em seu retorno sobre o patrimônio. Instituições com ROEs negativos de grande valor podem fazer com que se superestime o valor do patrimônio líquido mínimo, e aquelas com ROEs positivos excepcionalmente altos podem induzir ao erro de subestimação. Desta forma será realizada uma análise Box-Plot para eliminar os extremos.

O modelo de banco de dados utilizados é apresentado no Apêndice 9. Para o processamento das regressões será utilizado o software Stata e, para as demais estatísticas, o software SPSS.

\subsubsection{Regressões para estimação do beta}

Os dados para o cálculo do beta das instituições são provenientes da Economática. Obteve-se a cotação de fechamento diário de todas as instituições disponíveis. Os retornos mensais foram calculados a partir da variação entre as médias das cotações mensais, por instituição, como apresentado na equação (9). Minimizou-se assim o problema de séries de preços com ausência de dados em determinados dias. A mesma providência foi adotada para o IBOVESPA.

$$
\xi_{i ; j}=\ln \left(\frac{\mu_{i j}}{\mu_{i j-1}}\right)
$$

Em que:

$\xi_{\mathrm{ij}}$ é o retorno da ação i no mês $\mathrm{j}$

$\mu_{\mathrm{ij}}$ é a média das cotações de fechamento da ação i no mês $\mathrm{j}$

$\mu_{\mathrm{ij}-1}$ é a média das cotações de fechamento da ação i no mês j-1 
O modelo de regressão adotado foi o de painel com efeitos fixos. De acordo com Petersen (2009), o modelo de painel com efeito fixo produz erro padrão não viesado. O uso do modelo com efeitos fixos está em linha com Bianconi e Yoshino (2012).

A regressão adotada é definida pela equação (10).

$$
\xi_{i ; j}=\alpha+\beta_{1} \xi_{\text {IBOVESPA,j }}+\beta_{2} \ln \_\mathrm{pl}+u_{j}+\varepsilon_{i j}
$$

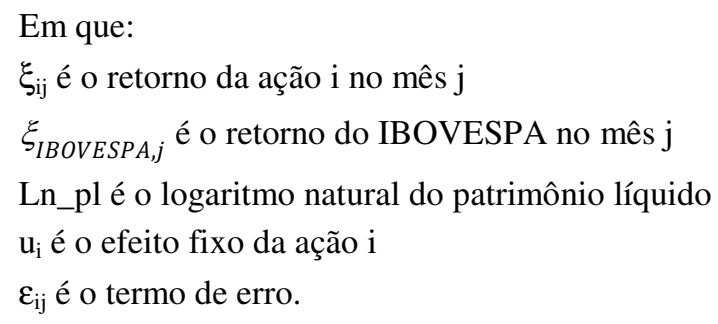

O patrimônio líquido foi obtido junto ao BACEN e corrigido pelo IPCA.

O modelo de banco de dados utilizado na estimação do beta está disponível no Apêndice 10 .

Em resumo, a estrutura do arquivo gerado continha os seguintes campos: instituição, data, retorno mensal da ação, retorno mensal do IBOVESPA e patrimônio líquido corrigido.

\subsubsection{Valor do patrimônio líquido mínimo das instituições}

De posse das regressões detalhadas em 4.9.1 e 4.9.2, o valor do patrimônio líquido mínimo será dado pela interseção entre as curvas determinantes do ROE e do $\mathrm{K}_{\mathrm{E}}$.

Admitindo-se $\mathrm{K}_{\mathrm{E}}$ constante, não correlacionado ao patrimônio líquido, e alavanc não correlacionado ao ROE, o patrimônio líquido mínimo é obtido pela interseção da curva entre o ROE e o PL com a curva entre o KE e o PL, conforme ilustrado na Ilustração 2. 


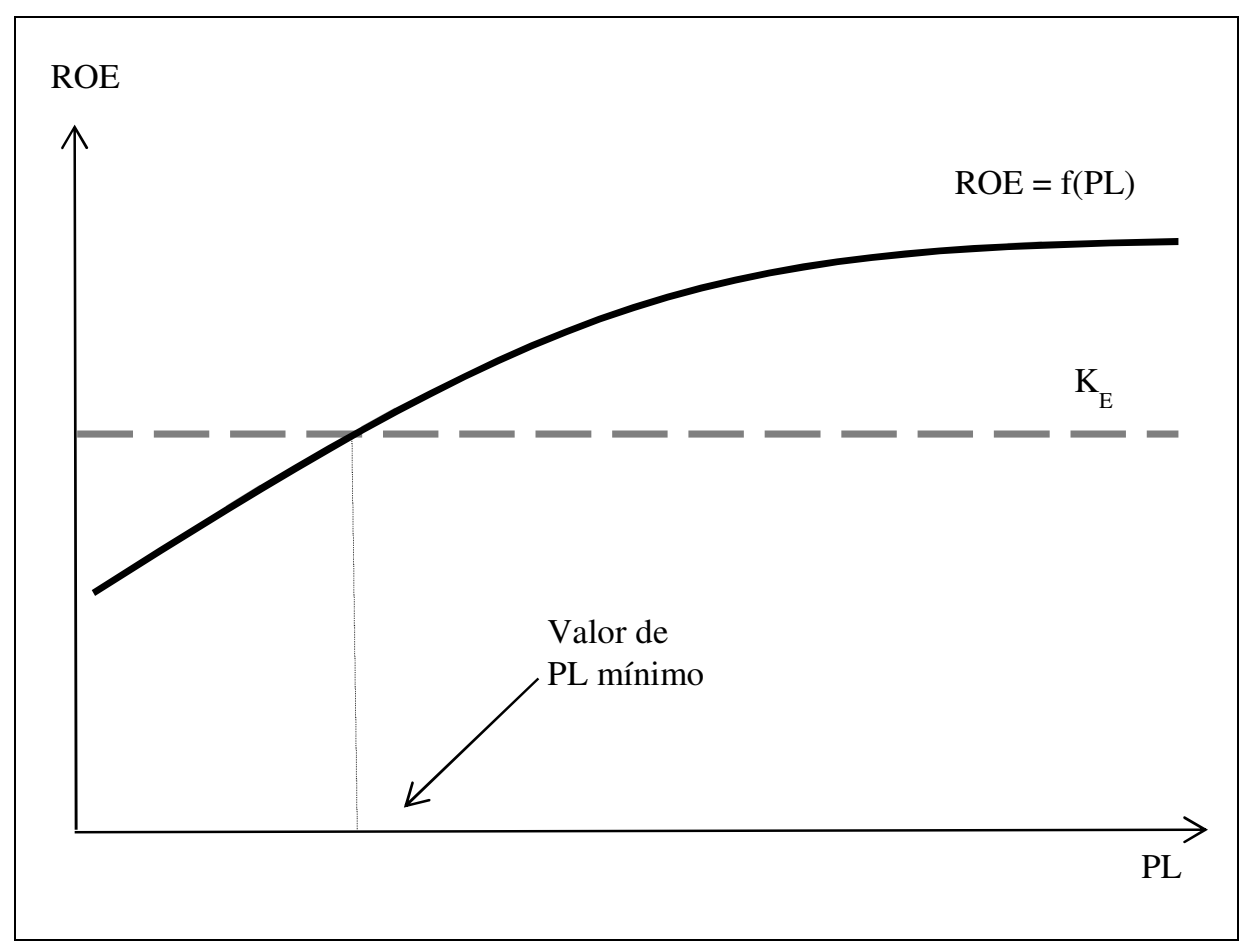

Ilustração 2 - Relações previstas com $K_{E}$ constante

A Ilustração 3 apresenta a situação em que $\mathrm{K}_{\mathrm{E}}$ é inversamente proporcional ao patrimônio líquido, e alavanc não é correlacionado ao ROE.

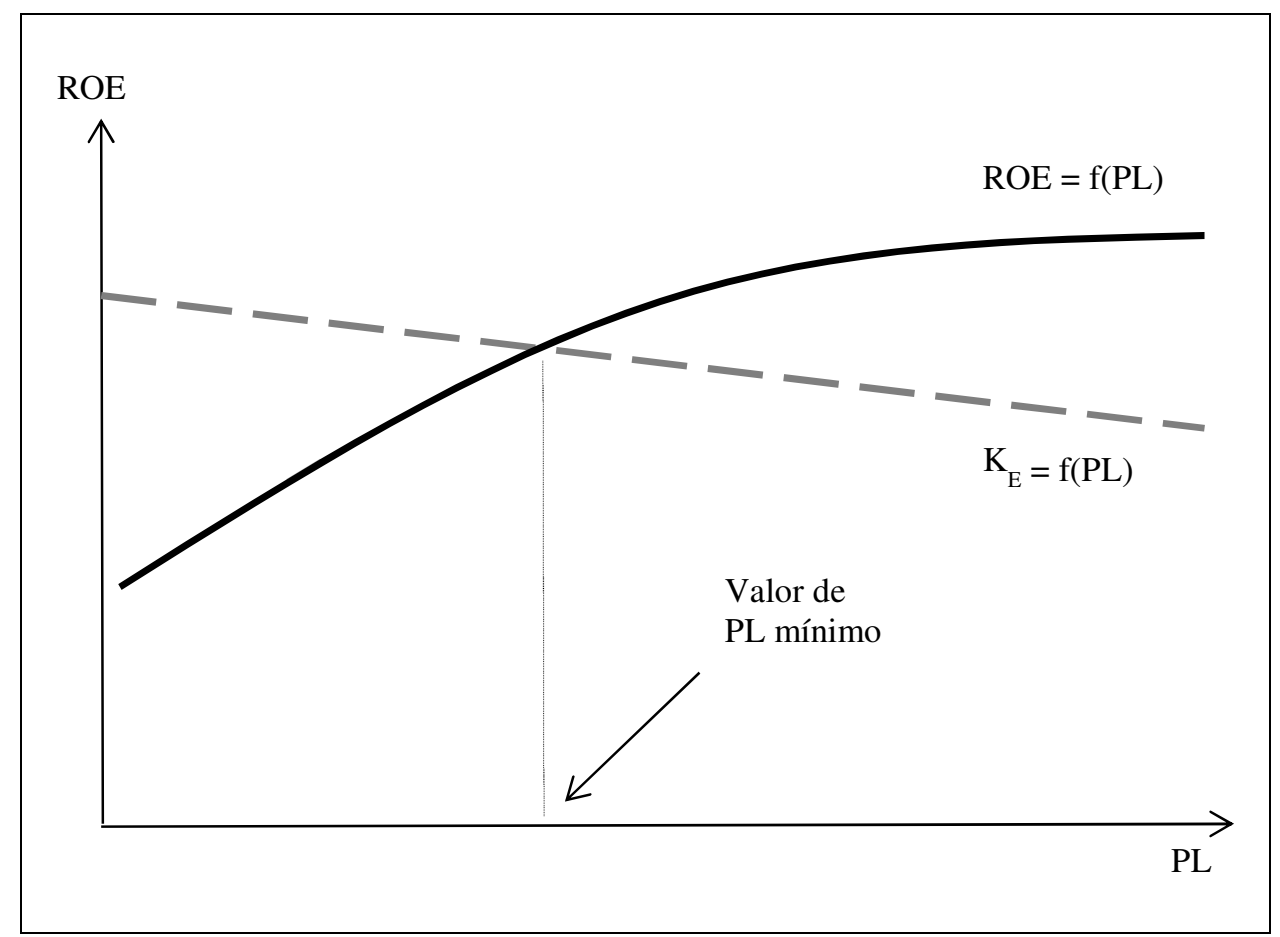

Ilustração 3 - Relações previstas para $K_{E}$ variável

Caso exista correlação entre o ROE e a variável representativa da alavancagem bancária, para cada nível de alavanc existirá uma curva (Ilustração 4). Admitindo-se que os administradores 
das instituições financeiras busquem o nível ótimo de alavancagem, ou seja, aquele que proporciona o maior valor de $\mathrm{ROE}$, o valor mínimo para o patrimônio líquido será aquele encontrado com a curva de ROE para a alavancagem ótima. Na Ilustração 4, a linha cheia representaria o ROE estimado com a alavancagem ótima.

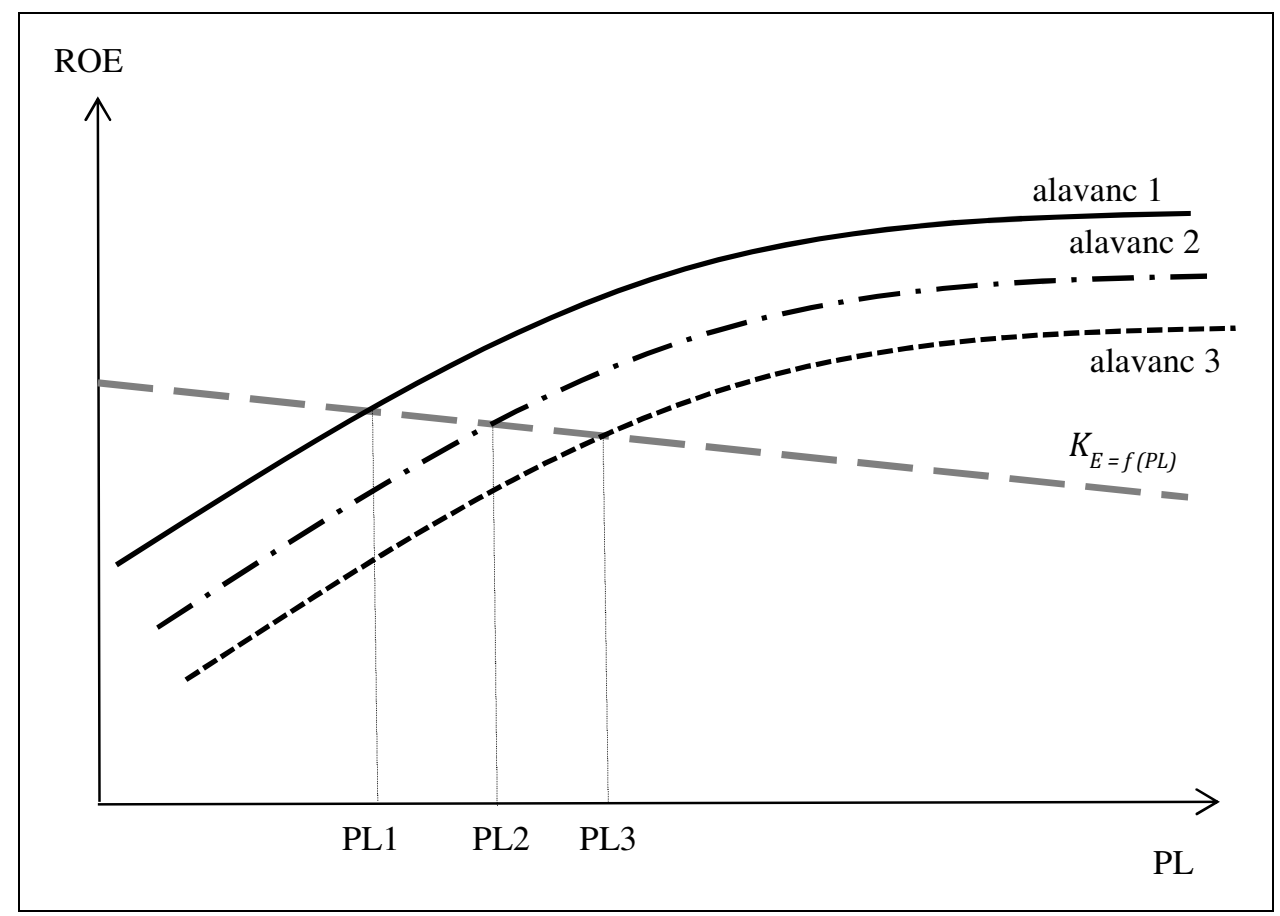

Ilustração 4 - Relações previstas para $K_{E}$ variável e para diferentes níveis de alavanc 


\section{ANÁLISE DOS RESULTADOS}

Este capítulo está dividido em sete seções. Na primeira são apresentadas as estatísticas descritivas de algumas variáveis que afetam o retorno das instituições, ou seja, o nível de imobilização, as despesas administrativas, as receitas com serviços, e as taxas médias de aplicação e de captação, de acordo com a tipologia. Na segunda seção foi realizada uma análise evolutiva dessas variáveis. Na terceira seção essas variáveis foram analisadas com a consideração do porte da instituição, respeitada sua tipologia; por isso, foi realizada uma análise de clusters para agrupar as instituições de acordo com seu porte. A quarta seção traz estatísticas descritivas das variáveis utilizadas no modelo de regressão. Desta forma, estas quatro primeiras seções são dedicadas exclusivamente à obtenção de uma melhor compreensão dos fatores que afetam o retorno das instituições.

As três seções subsequentes visam responder à questão principal de pesquisa. A quinta seção destinou-se à construção de uma curva de retorno em função do porte da instituição, obtida pela regressão em que o ROE é a variável dependente e o patrimônio líquido e a alavancagem bancária as variáveis explicativas. Na sexta seção estimou-se o custo de capital próprio das instituições, também definido em função do porte, dando origem a uma curva do custo de capital. Finalmente, na sétima seção foram confrontadas as curvas de retorno das instituições com a curva do custo de capital, onde o intercepto define o valor do patrimônio líquido a partir do qual o ROE supera o custo de capital.

\subsection{Estatísticas descritivas}

As estatísticas calculadas nesta seção basearam-se exclusivamente nas informações financeiras de dezembro de 2014. Preferiu-se não utilizar as informações dos demais demonstrativos, à semelhança de um painel com a abordagem Pools, porque algumas instituições não apresentaram seus demonstrativos com regularidade, o que daria maior peso àqueles que apresentaram todos os 10 balanços do período analisado.

A Tabela 12 apresenta as estatísticas descritivas das variáveis que caracterizam o porte das instituições financeiras, isto é, o ativo total e o patrimônio líquido, extraídas dos 
demonstrativos de dezembro de 2014. Os coeficientes de variação indicam que as dimensões dos bancos de investimento e das sociedades de crédito imobiliário têm a menor variabilidade entre si; em oposição, os bancos com carteira comercial apresentam grande disparidade no tocante a seu porte.

Tabela 12 - Estatísticas descritivas: ativo total e patrimônio líquido

\begin{tabular}{llrrrr}
\hline & \multicolumn{4}{c}{ Tipologia } \\
\cline { 2 - 6 } Variável / Estatística & \multicolumn{1}{c}{$\begin{array}{c}\text { Banco } \\
\text { Comercial }\end{array}$} & $\begin{array}{c}\text { Banco de } \\
\text { Investimento }\end{array}$ & Financeira & $\begin{array}{c}\text { Sociedade } \\
\text { de Crédito } \\
\text { Imobiliário }\end{array}$ \\
\hline Número de instituições & 94 & 33 & 39 & 8 \\
\hline & Média & 66.457 .992 & 3.871 .283 & 511.909 & 94.303 \\
& Desvio padrão & 230.961 .539 & 5.395 .681 & 990.068 & 74.817 \\
Ativo total & Máximo & 1.324 .464 .414 & 26.051 .454 & 4.604 .386 & 258.345 \\
& Mínimo & 48.639 & 25.284 & 12.874 & 32.887 \\
& Coef. de variação & 3,48 & 1,39 & 1,93 & 0,79 \\
\hline \multirow{2}{*}{ Patrimônio } & Média & 4.901 .700 & 517.529 & 138.835 & 14.216 \\
Líquido & Máximo & 16.317 .514 & 572.847 & 368.123 & 7.455 \\
& Mínimo & 103.079 .063 & 2.621 .370 & 2.168 .517 & 23.196 \\
& Coef. de variação & 16.274 & 20.939 & 5.661 & 3.280 \\
\hline Nota: vadrão & 3,33 & 1,11 & 2,65 & 0,52 \\
\hline
\end{tabular}

Nota: valores em R $\$ 1.000,00$

A Tabela 13 apresenta as estatísticas descritivas de variáveis relativas extraídas dos balanços de dezembro de 2014. Desta forma, analisou-se o ativo imobilizado pela relação entre o mesmo e o patrimônio liquido, tal como no índice de imobilização do BACEN. As despesas administrativas foram analisadas pela sua relação com o ativo total. A variável denominada Mix refere-se à proporção das receitas com serviços e tarifas relativamente à soma das receitas, deduzidas as despesas de intermediação. A variável taxa de aplicação refere-se à relação entre receitas de intermediação, das quais foram deduzidas as perdas com inadimplência, pelo ativo financeiro, definido como a diferença entre o ativo total e o ativo permanente. Da forma semelhante, foi calculada a taxa média de captação. E o spread é dado pela diferença aritmética entre a taxa média de aplicação e a de captação. 
Tabela 13 - Estatísticas descritivas: variáveis relativas

\begin{tabular}{|c|c|c|c|c|c|}
\hline \multirow[b]{2}{*}{ Variável } & \multirow[b]{2}{*}{ Estatística } & \multicolumn{4}{|c|}{ Tipologia } \\
\hline & & Banco Comercial & $\begin{array}{l}\text { Banco de } \\
\text { Investimento }\end{array}$ & Financeira & $\begin{array}{l}\text { Sociedade } \\
\text { de Crédito } \\
\text { Imobiliário }\end{array}$ \\
\hline & $\mathrm{N}^{\circ}$ de Instituições & 94 & 33 & 39 & 8 \\
\hline \multirow{5}{*}{ Imob/PL } & Média & 0,1286 & 0,0513 & 0,0345 & 0,0978 \\
\hline & Desvio padrão & 0,14 & 0,0788 & 0,0655 & 0,1403 \\
\hline & Máximo & 0,622 & 0,329 & 0,299 & 0,439 \\
\hline & Mínimo & 0,001 & 0,001 & 0,001 & 0,006 \\
\hline & Coef. de variação & 1,089 & 1,536 & 1,899 & 1,435 \\
\hline \multirow{5}{*}{ Despadm/AT $_{\text {ad }}$} & Média & 0,0467 & 0,0386 & 0,0751 & 0,0549 \\
\hline & Desvio padrão & 0,0664 & 0,0438 & 0,0489 & 0,0302 \\
\hline & Máximo & 0,478 & 0,218 & 0,1811 & 0,0989 \\
\hline & Mínimo & 0,0002 & 0,0042 & 0,014 & 0,0145 \\
\hline & Coef. de variação & 1,422 & 1,135 & 0,651 & 0,55 \\
\hline \multirow{5}{*}{ Mix } & Média & 0,2828 & 0,2134 & 0,0998 & 0,2125 \\
\hline & Desvio padrão & 0,2577 & 0,2347 & 0,13 & 0,3004 \\
\hline & Máximo & 0,9383 & 0,886 & 0,4869 & 0,8552 \\
\hline & Mínimo & 0 & 0 & 0 & 0 \\
\hline & Coef. de variação & 0,911 & 1,1 & 1,303 & 1,414 \\
\hline \multirow{5}{*}{$\mathrm{Tx}_{\text {aplic }}(\% \mathrm{CDI})$} & Média & 1,4593 & 1,5073 & 3,4035 & 0,8436 \\
\hline & Desvio padrão & 0,9301 & 1,1586 & 2,1852 & 0,4411 \\
\hline & Máximo & 5,8842 & 6,4857 & 9,6232 & 1,4607 \\
\hline & Mínimo & 0,4066 & 0,3876 & 1,1527 & 0,1716 \\
\hline & Coef. de variação & 0,637 & 0,769 & 0,642 & 0,523 \\
\hline \multirow{5}{*}{$\mathrm{Tx}_{\mathrm{capt}}(\% \mathrm{CDI})$} & Média & 1,1179 & 1,2449 & 1,0752 & 0,3408 \\
\hline & Desvio padrão & 0,9703 & 1,9768 & 0,9723 & 0,3603 \\
\hline & Máximo & 7,8186 & 10,8521 & 5,4979 & 0,8106 \\
\hline & Mínimo & 0,0014 & 0,0016 & 0,0172 & 0,0086 \\
\hline & Coef. de variação & 0,868 & 1,588 & 0,904 & 1,057 \\
\hline \multirow{5}{*}{$\begin{array}{l}\text { Spread } \\
(\% \text { a.a.) }\end{array}$} & Média & 0,0404 & 0,0364 & 0,2816 & 0,0571 \\
\hline & Desvio padrão & 0,0991 & 0,0831 & 0,2951 & 0,0547 \\
\hline & Máximo & 0,6131 & 0,2438 & 1,1857 & 0,1597 \\
\hline & Mínimo & $-0,1451$ & $-0,2812$ & $-0,3047$ & 0,0062 \\
\hline & Coef. de variação & 2,453 & 2,283 & 1,048 & 0,958 \\
\hline
\end{tabular}

Antes de se estabelecer qualquer comparativo entre diferentes modalidades de instituição financeira, faz-se necessário verificar se as médias das variáveis relacionais são 
estatisticamente diferentes. A comparação de médias é realizada por dois métodos: o teste Anova, cuja premissa é a normalidade das variáveis, e o teste de Kruscal Wallis. Desta forma, faz-se necessário testar a normalidade, o que é apresentado na Tabela 14. Amostras maiores, como no caso, devem se basear no teste de Kolmogorov-Smirnov, que rejeitou a normalidade para todas as variáveis.

Tabela 14 - Teste Kolmogorov-Smirnov para normalidade: variáveis relativas

\begin{tabular}{ccccccc}
\hline \multirow{2}{*}{ Variável } & \multicolumn{3}{c}{ Kolmogorov-Smirnov } & \multicolumn{3}{c}{ Shapiro-Wilk } \\
\cline { 2 - 7 } & Statistic & df & Sig. & Statistic & df & Sig. \\
\hline Imob/PL & 0,237 & 142 & 0,000 & 0,720 & 142 & 0,000 \\
Desp $_{\mathrm{adm} / \mathrm{AT}}$ & 0,214 & 146 & 0,000 & 0,648 & 146 & 0,000 \\
$\mathrm{Mix}$ & 0,179 & 146 & 0,000 & 0,852 & 146 & 0,000 \\
$\mathrm{Tx}_{\text {aplic }}$ (\% CDI) & 0,199 & 146 & 0,000 & 0,758 & 146 & 0,000 \\
$\mathrm{Tx}_{\text {capt }}$ (\%CDI) & 0,210 & 146 & 0,000 & 0,656 & 146 & 0,000 \\
Spread $(\%$ a.a.) & 0,231 & 146 & 0,000 & 0,681 & 146 & 0,000 \\
\hline
\end{tabular}

A Tabela 15 apresenta o teste de Kruscal Wallis, que rejeita a igualdade das médias de todas as variáveis.

Tabela 15 - Teste de Kruscal Wallis para igualdade de médias: variáveis relativas

\begin{tabular}{|c|c|c|c|}
\hline Variável & Chi-Square & df & Asymp. Sig. \\
\hline Imob/PL & 32,348 & 3 & 0,000 \\
\hline $\operatorname{Desp}_{\mathrm{adm}}$ AT $_{\mathrm{AT}}$ & 23,793 & 3 & 0,000 \\
\hline Mix & 18,690 & 3 & 0,000 \\
\hline $\mathrm{Tx}_{\text {aplic }}(\% \mathrm{CDI})$ & 47,175 & 3 & 0,000 \\
\hline $\mathrm{Tx}_{\text {capt }}(\% \mathrm{CDI})$ & 9,331 & 3 & 0,025 \\
\hline Spread (\% a.a.) & 51,004 & 3 & 0,000 \\
\hline
\end{tabular}

Desta forma, é possível extrair as seguintes conclusões, com base em análise da Tabela 13:

- Guardada a proporcionalidade com o patrimônio líquido, os bancos com carteira comercial tem ativo imobilizado muito superior ao das demais instituições. São várias as possíveis explicações para isto. Muitas vezes os bancos possuem estruturas de atendimento onerosas, com rede de agências espalhadas pelo país, e necessitam 
fazer pesados investimentos em tecnologia da informação.

- Bancos comerciais e de investimento apresentam menores quocientes entre as despesas administrativas e o ativo total, comparativamente às sociedades de crédito imobiliário e financeiras. Esta constatação pode encontrar explicação no maior porte dos bancos, como mostrado na Tabela 12, o que suscita a discussão sobre a economia de escala. No entanto, o coeficiente de variação dos bancos é superior, o que pode ser decorrência da maior variabilidade de porte dos bancos, se medido pelo ativo total.

- No tocante à proporção das receitas com serviços e tarifas (mix), os bancos comerciais apresentam média superior às demais modalidades de instituição. Isto se justifica pelo fato de que eles podem captar recursos em depósito à vista, o que lhes confere a oportunidade de oferecer a seus clientes serviços como conta corrente, transferências, cobrança, etc. Isto justifica a maior participação das receitas de serviço e tarifas nos resultados, em relação às demais modalidades de instituições financeiras.

- As taxas médias de aplicação das financeiras é a maior entre todas. Isto se explica pela modalidade de operação de crédito que predomina nestas instituições, que é o financiamento ao consumo para pessoas físicas.

- As sociedades de crédito imobiliário têm a menor taxa média de aplicação. Os financiamentos imobiliários, principal ativo destas companhias têm, comparativamente ao ativo das financeiras, um risco inferior, visto que são colateralizados pelo imóvel financiado.

- No tocante à taxa média de captação, pode-se observar que as sociedades de crédito imobiliário têm o menor custo. É importante mencionar que os recursos destas companhias são provenientes da poupança, de repasses interfinanceiros ${ }^{6}$, e de títulos

\footnotetext{
${ }^{6}$ Existe uma modalidade de repasse interfinanceiro que permite às instituições financeiras captadoras de depósitos em poupança repassarem esses recursos às instituições que originam financiamentos imobiliários, e assim atenderem às aplicações compulsórias estabelecidas pela Resolução no 3.932/2010.
} 
do mercado imobiliário que, por se beneficiarem de isenção tributária, são colocados no mercado a uma taxa inferior à dos demais títulos de renda fixa.

- Pelas razões acima se explica o menor spread das sociedades de crédito imobiliário, relativamente às financeiras.

- As comparações entre as estatísticas dos bancos com carteira comercial e dos bancos de investimento é mais complexa. Os ativos destas instituições são diversificados no tocante à sua modalidade, e incluem financiamento ao capital de giro das empresas, operações do mercado de capitais, financiamentos com recursos provenientes de repasses do BNDES, financiamento ao consumo, operações de arrendamento mercantil, desconto de títulos, etc. De forma geral, o mercado de atuação dos bancos de investimento é o corporativo; esta pode ser uma explicação razoável da razão pela qual o spread deste segmento ser pouco inferior ao dos bancos comerciais.

As diferenças constatadas entre estas variáveis decorrem das diferenças de perfil de cada modalidade de instituição e sugerem que é melhor agrupá-las segundo sua tipologia, antes de proceder a qualquer análise estatística.

\subsection{Estatísticas descritivas evolutivas}

Cumpre verificar se estas variáveis são estáveis ao longo do período analisado. A Tabela 16 apresenta as estatísticas das variáveis analisadas na seção anterior agrupadas pelo semestre a que o balanço se refere. Note-se que só existem estatísticas para financeiras e sociedades de crédito imobiliário apenas a partir do $3^{\circ}$ trimestre analisado, ou seja, junho de 2011. 
Tabela 16 - Estatísticas descritivas semestrais

\begin{tabular}{|c|c|c|c|c|c|c|c|c|}
\hline \multirow[t]{2}{*}{ Tipologia } & \multicolumn{2}{|c|}{ Semestre } & \multirow{2}{*}{$\frac{\frac{\mathbf{I m o b}}{\mathbf{P L}}}{0,1282}$} & \multirow{2}{*}{$\frac{\frac{\text { Desp }_{\text {adm }}}{\mathbf{A T}}}{0,0418}$} & \multirow{2}{*}{$\begin{array}{c}\text { Mix } \\
0,2373\end{array}$} & \multirow{2}{*}{$\begin{array}{c}\begin{array}{c}\text { Txx } \\
\text { aplic } \\
(\% \text { CDI })\end{array} \\
1,7076\end{array}$} & \multirow{2}{*}{$\begin{array}{c}\begin{array}{c}\mathbf{T} \mathbf{x}_{\text {capt }} \\
(\% \mathbf{C D I})\end{array} \\
1,0390\end{array}$} & \multirow{2}{*}{$\begin{array}{c}\text { Spread } \\
\text { (\% a.a.) }\end{array}$} \\
\hline & $1^{\circ}$ & jun/10 & & & & & & \\
\hline \multirow{9}{*}{$\begin{array}{l}\text { Banco } \\
\text { Comercial }\end{array}$} & $2^{\circ}$ & $\operatorname{dez} / 10$ & 0,1355 & 0,0468 & 0,2409 & 1,3205 & 0,8005 & 0,0549 \\
\hline & $3^{\circ}$ & jun/11 & 0,1241 & 0,0394 & 0,2426 & 1,1366 & 0,7625 & 0,0419 \\
\hline & $4^{\circ}$ & $\operatorname{dez} / 11$ & 0,1176 & 0,0455 & 0,2324 & 1,5266 & 1,2302 & 0,0370 \\
\hline & $5^{\circ}$ & jun/12 & 0,1265 & 0,0421 & 0,2419 & 1,4777 & 1,0173 & 0,0439 \\
\hline & $6^{\circ}$ & $\mathrm{dez} / 12$ & 0,1238 & 0,0502 & 0,2497 & 1,5805 & 0,9146 & 0,0492 \\
\hline & $7^{\circ}$ & jun/13 & 0,1186 & 0,0515 & 0,2542 & 1,8163 & 1,1239 & 0,0506 \\
\hline & $8^{\circ}$ & $\operatorname{dez} / 13$ & 0,1231 & 0,0565 & 0,2772 & 1,4018 & 0,9660 & 0,0411 \\
\hline & $9^{\circ}$ & jun/14 & 0,1470 & 0,0456 & 0,3092 & 1,0762 & 0,7495 & 0,0332 \\
\hline & $10^{\circ}$ & $\mathrm{dez} / 14$ & 0,1286 & 0,0467 & 0,2828 & 1,4593 & 1,1179 & 0,0404 \\
\hline \multirow{10}{*}{$\begin{array}{l}\text { Banco de } \\
\text { Investimento }\end{array}$} & $1^{\circ}$ & jun/10 & 0,1088 & 0,0348 & 0,2293 & 2,0163 & 1,6805 & 0,0291 \\
\hline & $2^{\circ}$ & $\mathrm{dez} / 10$ & 0,1048 & 0,0376 & 0,2228 & 1,8168 & 1,4428 & 0,0385 \\
\hline & $3^{\circ}$ & jun/11 & 0,1042 & 0,0340 & 0,1706 & 1,6345 & 1,3429 & 0,0318 \\
\hline & $4^{\circ}$ & $\operatorname{dez} / 11$ & 0,0900 & 0,0311 & 0,1979 & 1,7918 & 1,4364 & 0,0407 \\
\hline & $5^{\circ}$ & jun/12 & 0,0825 & 0,0338 & 0,2534 & 1,7903 & 1,5743 & 0,0241 \\
\hline & $6^{\circ}$ & $\mathrm{dez} / 12$ & 0,0665 & 0,0359 & 0,2052 & 1,9705 & 1,4937 & 0,0367 \\
\hline & $7^{\circ}$ & jun/13 & 0,0592 & 0,0349 & 0,2374 & 2,0019 & 1,7709 & 0,0210 \\
\hline & $8^{\circ}$ & $\mathrm{dez} / 13$ & 0,0593 & 0,0413 & 0,2665 & 1,4766 & 1,2149 & 0,0264 \\
\hline & $9^{\circ}$ & jun/14 & 0,0531 & 0,0329 & 0,2426 & 1,3115 & 1,0414 & 0,0302 \\
\hline & $10^{\circ}$ & $\mathrm{dez} / 14$ & 0,0513 & 0,0386 & 0,2134 & 1,5073 & 1,2449 & 0,0364 \\
\hline \multirow{8}{*}{ Financeira } & $3^{\circ}$ & jun/11 & 0,0294 & 0,0470 & 0,1074 & 0,9873 & 0,1059 & 0,1004 \\
\hline & $4^{\circ}$ & $\mathrm{dez} / 11$ & 0,0282 & 0,0833 & 0,0915 & 3,3201 & 0,9884 & 0,2905 \\
\hline & $5^{\circ}$ & jun/12 & & 0,0701 & 0,0910 & 3,8000 & 1,0792 & 0,2775 \\
\hline & $6^{\circ}$ & $\mathrm{dez} / 12$ & 0,0338 & 0,0739 & 0,1126 & 4,8939 & 1,4370 & 0,2879 \\
\hline & $7^{\circ}$ & jun/13 & 0,0323 & 0,0768 & 0,1107 & 5,2131 & 1,5534 & 0,3045 \\
\hline & $8^{\circ}$ & $\mathrm{dez} / 13$ & 0,0373 & 0,0780 & 0,1094 & 3,7983 & 0,8399 & 0,2900 \\
\hline & $9^{\circ}$ & jun/14 & 0,0354 & 0,0705 & 0,1022 & 3,5857 & 1,1489 & 0,2671 \\
\hline & $10^{\circ}$ & $\mathrm{dez} / 14$ & 0,0345 & 0,0751 & 0,0998 & 3,4035 & 1,0752 & 0,2816 \\
\hline \multirow{8}{*}{$\begin{array}{l}\text { Sociedade } \\
\text { de Crédito } \\
\text { Imobiliário }\end{array}$} & $3^{\circ}$ & jun/11 & 0,0743 & 0,0268 & 0,1864 & 0,3971 & 0,1171 & 0,0312 \\
\hline & $4^{\circ}$ & $\mathrm{dez} / 11$ & 0,0673 & 0,0659 & 0,1061 & 1,0737 & 0,4994 & 0,0675 \\
\hline & $5^{\circ}$ & jun/12 & & 0,0703 & 0,1309 & 1,0569 & 0,3767 & 0,0642 \\
\hline & $6^{\circ}$ & $\mathrm{dez} / 12$ & 0,0743 & 0,0753 & 0,1941 & 1,2213 & 0,3668 & 0,0638 \\
\hline & $7^{\circ}$ & jun/13 & 0,0640 & 0,0395 & 0,2847 & 0,9119 & 0,3704 & 0,0384 \\
\hline & $8^{\circ}$ & $\mathrm{dez} / 13$ & 0,0589 & 0,0569 & 0,1834 & 1,0004 & 0,3338 & 0,0612 \\
\hline & $9^{\circ}$ & jun/14 & 0,0615 & 0,0395 & 0,1007 & 0,8051 & 0,4313 & 0,0380 \\
\hline & $10^{\circ}$ & $\mathrm{dez} / 14$ & 0,0978 & 0,0549 & 0,2125 & 0,8436 & 0,3408 & 0,0571 \\
\hline
\end{tabular}


Com o intuito de verificar se as médias semestrais são estatisticamente iguais, procedeu-se ao teste de médias, o que é apresentado na Tabela 17.

Tabela 17 - Teste de Kruscal Wallis para igualdade de médias - médias temporais

\begin{tabular}{|c|c|c|c|c|c|c|c|}
\hline Tipologia & Estatística & $\frac{\text { Imob }}{\text { PL }}$ & $\frac{\text { Desp }_{\text {adm }}}{\text { AT }}$ & Mix & $\begin{array}{l}\mathbf{T x}_{\text {aplic }} \\
(\% \text { CDI })\end{array}$ & $\begin{array}{l}\mathbf{T x}_{\text {capt }} \\
(\% \text { CDI })\end{array}$ & $\begin{array}{l}\text { Spread } \\
\text { (\% a.a.) }\end{array}$ \\
\hline \multirow{3}{*}{$\begin{array}{l}\text { Banco } \\
\text { Comercial }\end{array}$} & Chi-Square & 1,739 & 3,662 & 6,227 & 77,416 & 59,884 & 19,850 \\
\hline & $\mathrm{df}$ & 9 & 9 & 9 & 9 & 9 & 9 \\
\hline & Asymp. Sig. & 0,995 & 0,932 & 0,717 & 0,000 & 0,000 & 0,019 \\
\hline \multirow{3}{*}{$\begin{array}{l}\text { Banco de } \\
\text { Investimento }\end{array}$} & Chi-Square & 2,784 & 4,296 & 4,479 & 16,850 & 16,274 & 4,149 \\
\hline & $\mathrm{df}$ & 9 & 9 & 9 & 9 & 9 & 9 \\
\hline & Asymp. Sig. & 0,972 & 0,891 & 0,877 & 0,051 & 0,061 & 0,901 \\
\hline \multirow{3}{*}{ Financeira } & Chi-Square & 2,784 & 4,296 & 4,479 & 16,850 & 16,274 & 4,149 \\
\hline & $\mathrm{df}$ & 9 & 9 & 9 & 9 & 9 & 9 \\
\hline & Asymp. Sig. & 0,972 & 0,891 & 0,877 & 0,051 & 0,061 & 0,901 \\
\hline \multirow{3}{*}{$\begin{array}{l}\text { Sociedade } \\
\text { de Crédito } \\
\text { Imobiliário }\end{array}$} & Chi-Square & ,993 & 10,489 & 3,205 & 9,228 & 2,941 & 3,116 \\
\hline & $\mathrm{df}$ & 6 & 7 & 7 & 7 & 7 & 7 \\
\hline & Asymp. Sig. & 0,986 & 0,163 & 0,865 & 0,237 & 0,890 & 0,874 \\
\hline
\end{tabular}

Observada a tipologia, as médias semestrais das variáveis relacionadas ao ativo imobilizado, às despesas administrativas e à proporção de receita com serviços são estatisticamente iguais. Quanto ao spread e às taxas médias de aplicação e captação, as médias semestrais são estatisticamente diferentes apenas no caso dos bancos com carteira comercial; para as demais modalidades de instituição ocorre a igualdade entre as médias. Conclui-se que, de forma geral, existe certa estabilidade das variáveis elencadas ao longo do tempo.

\subsection{Estatística descritiva com clusters definidos pelo patrimônio líquido}

Esta análise tem como objetivo verificar a relação entre o patrimônio líquido e as variáveis estudadas. Os dados referem-se a dezembro de 2014. A metodologia utilizada foi descrita em 4.8.2. O patrimônio líquido foi considerado na forma de logaritmo natural. As instituições, independentemente de sua tipologia, foram classificadas em uma única escala, para permitir a comparabilidade entre instituições de mesmo porte, mas de tipologias diferentes. 
Inicialmente procedeu-se a uma análise exploratória para definir o número ideal de conglomerados. A Tabela 18 apresenta os dez estágios finais dos métodos de agrupamento between groups, centróide e Ward, os coeficientes de proximidade associados a cada estágio e a variação destes coeficientes, relativamente ao estágio anterior.

Tabela 18 - Análise de conglomerados: coeficientes de proximidade por estágio

\begin{tabular}{rrrrrrr}
\hline & \multicolumn{2}{c}{ Between Groups } & \multicolumn{2}{c}{ Centróide } & \multicolumn{2}{c}{ Ward } \\
\cline { 2 - 7 } & Coeficiente & Variação & Coeficiente & Variação & Coeficiente & Variação \\
\hline 164 & 0,701 & $31 \%$ & 0,614 & $30 \%$ & 10,864 & $21 \%$ \\
165 & 0,764 & $9 \%$ & 0,692 & $13 \%$ & 15,115 & $39 \%$ \\
166 & 0,887 & $16 \%$ & 0,782 & $13 \%$ & 19,952 & $32 \%$ \\
167 & 1,090 & $23 \%$ & 1,007 & $29 \%$ & 27,226 & $36 \%$ \\
168 & 1,978 & $81 \%$ & 1,681 & $67 \%$ & 41,237 & $51 \%$ \\
169 & 2,008 & $2 \%$ & 1,697 & $1 \%$ & 58,013 & $41 \%$ \\
170 & 3,365 & $68 \%$ & 2,975 & $75 \%$ & 85,953 & $48 \%$ \\
171 & 7,818 & $132 \%$ & 6,408 & $115 \%$ & 150,086 & $75 \%$ \\
172 & 12,432 & $59 \%$ & 10,171 & $59 \%$ & 326,559 & $118 \%$ \\
173 & 39,645 & $0 \%$ & 35,991 & $0 \%$ & 754,516 & $0 \%$ \\
\hline
\end{tabular}

O Gráfico 7 apresenta o coeficiente de proximidade, transformado em número índice, com valor $100 \%$ para o último estágio, para permitir a comparabilidade entre os métodos.

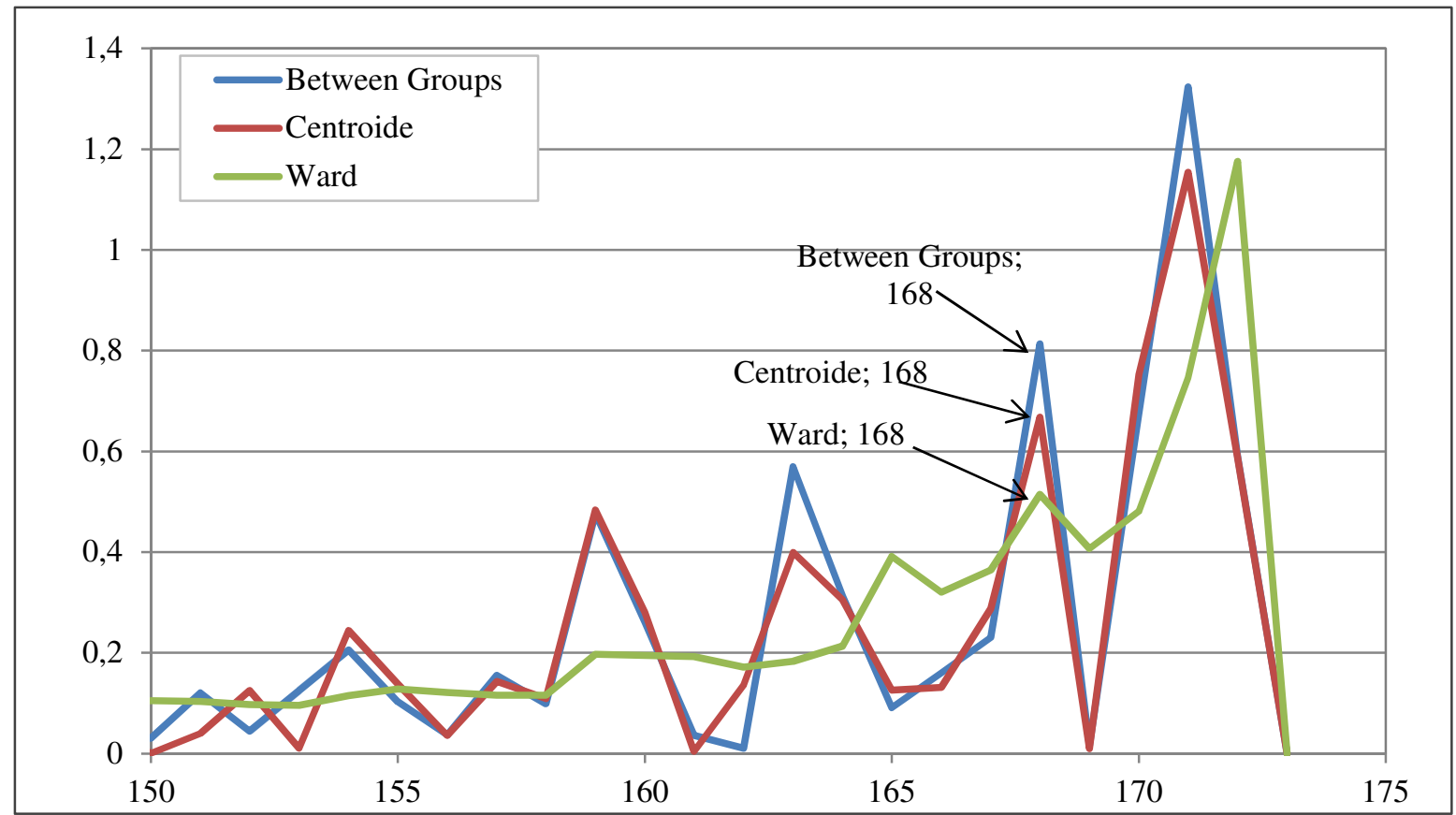

Gráfico 7 - Análise de conglomerados: coeficientes de proximidade em número índice 
O Gráfico 8 apresenta a variação destes coeficientes. Pode-se observar que no estágio 168 ocorreu uma grande variação dos coeficientes de proximidade pelos três métodos de aglomeração. Desta forma, considerando-se o estágio 168 como referência, deve-se escolher o número de clusters do estágio imediatamente anterior, ou seja, o de número 167. Para uma amostra de 174 elementos, isto significa a adoção de 7 clusters.

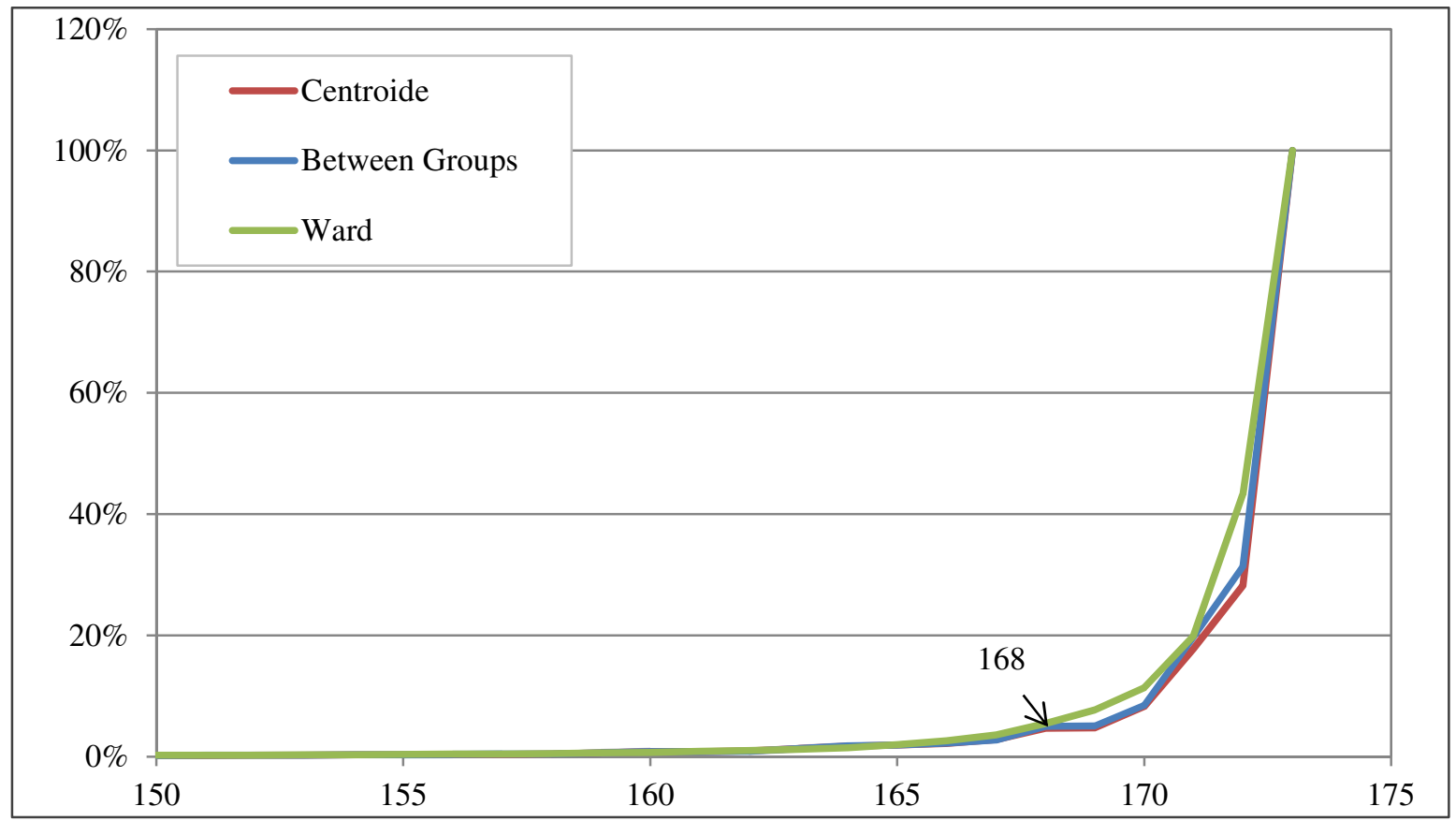

Gráfico 8 - Análise de conglomerados: variação percentual dos coeficientes de proximidade

Procedendo-se à classificação das instituições em 7 conglomerados pelo método de K-médias têm-se os centróides apresentados na Tabela 19, baseados no logaritmo natural do patrimônio líquido.

Tabela 19 - Análise de conglomerados: centróides do método de K-Médias

\begin{tabular}{lccccccc}
\hline Cluster & $\mathbf{1}$ & $\mathbf{2}$ & $\mathbf{3}$ & $\mathbf{4}$ & $\mathbf{5}$ & $\mathbf{6}$ & $\mathbf{7}$ \\
\hline Ln (PL) & 9,22 & 10,39 & 11,73 & 13,18 & 14,37 & 16,01 & 18,16 \\
PL & 10.114 & 32.679 & 124.824 & 529.839 & 1.732 .899 & 8.990 .801 & 76.699 .059 \\
\hline
\end{tabular}

Valores de PL em R\$1.000,00

A relação das instituições, de acordo com o cluster, é apresentada nos Apêndices.

A Tabela 20 apresenta as médias das variáveis estudadas, por tipologia e por conglomerado. Os bancos com carteira comercial foram classificados em 6 clusters, os bancos de investimento em 4 clusters, as sociedades de crédito imobiliário em apenas 2 clusters e as 
financeiras em 3.

Tabela 20 - Média das principais variáveis relativas, de acordo com o porte da instituição

\begin{tabular}{|c|c|c|c|c|c|c|c|c|}
\hline \multirow{2}{*}{ Tipo } & \multirow{2}{*}{ Variável } & \multicolumn{7}{|c|}{ Cluster } \\
\hline & & 1 & 2 & 3 & 4 & 5 & 6 & 7 \\
\hline \multirow{7}{*}{ 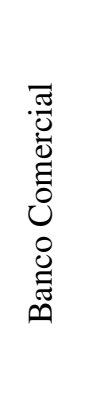 } & $\mathrm{N}^{\mathrm{o}}$ Instituições & 2 & 11 & 23 & 22 & 24 & 8 & 4 \\
\hline & Imob / PL & 0,076 & 0,149 & 0,101 & 0,110 & 0,111 & 0,181 & 0,370 \\
\hline & Desp $_{\text {adm }} / \mathrm{AT}$ & 0,249 & 0,080 & 0,065 & 0,028 & 0,027 & 0,021 & 0,025 \\
\hline & Mix & 0,913 & 0,134 & 0,240 & 0,274 & 0,298 & 0,337 & 0,518 \\
\hline & $\mathrm{Tx}_{\text {aplic }}(\% \mathrm{CDI})$ & 0,795 & 1,890 & 1,727 & 1,517 & 1,269 & 1,001 & 0,995 \\
\hline & $\mathrm{Tx}_{\mathrm{capt}}(\% \mathrm{CDI})$ & 0,600 & 1,196 & 1,210 & 1,301 & 1,001 & 0,848 & 0,857 \\
\hline & Spread (\% a.a.) & 0,024 & 0,082 & 0,065 & 0,025 & 0,030 & 0,017 & 0,015 \\
\hline \multirow{7}{*}{ 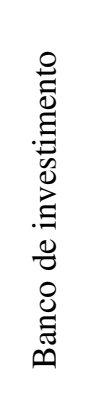 } & $\mathrm{N}^{\mathrm{o}}$ Instituições & - & 6 & 10 & 11 & 6 & - & - \\
\hline & Imob / PL & - & 0,075 & 0,051 & 0,042 & 0,045 & - & - \\
\hline & Desp $_{\text {adm }} / \mathrm{AT}$ & - & 0,056 & 0,056 & 0,018 & 0,030 & - & - \\
\hline & Mix & - & 0,229 & 0,228 & 0,175 & 0,237 & - & - \\
\hline & $\operatorname{Tx}_{\text {aplic }}(\% \mathrm{CDI})$ & - & 1,535 & 1,242 & 1,783 & 1,292 & - & - \\
\hline & $\mathrm{Tx}_{\text {capt }}(\% \mathrm{CDI})$ & - & 1,164 & 0,627 & 1,972 & 0,687 & - & - \\
\hline & Spread (\% a.a.) & - & 0,041 & 0,068 & $-0,003$ & 0,069 & - & - \\
\hline \multirow{7}{*}{ 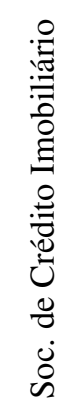 } & $\mathrm{N}^{\mathrm{o}}$ Instituições & 4 & 4 & - & - & - & - & - \\
\hline & Imob / PL & 0,138 & 0,058 & - & - & - & - & - \\
\hline & Desp $_{\text {adm }} / \mathrm{AT}$ & 0,066 & 0,044 & - & - & - & - & - \\
\hline & Mix & 0,119 & 0,337 & - & - & - & - & - \\
\hline & $\mathrm{Tx}_{\text {aplic }}(\% \mathrm{CDI})$ & 0,797 & 0,937 & - & - & - & - & - \\
\hline & $\mathrm{Tx}_{\text {capt }}(\% \mathrm{CDI})$ & 0,254 & 0,515 & - & - & - & - & - \\
\hline & Spread (\% a.a.) & 0,062 & 0,047 & - & - & - & - & - \\
\hline \multirow{7}{*}{ 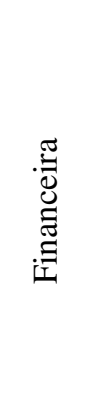 } & $\mathrm{N}^{\mathrm{o}}$ Instituições & 12 & 17 & 6 & 3 & 1 & - & - \\
\hline & Imob / PL & 0,036 & 0,025 & 0,073 & 0,006 & 0,010 & - & - \\
\hline & Desp $_{\text {adm }} / \mathrm{AT}$ & 0,065 & 0,077 & 0,079 & 0,083 & 0,128 & - & - \\
\hline & Mix & 0,076 & 0,092 & 0,118 & 0,239 & 0,000 & - & - \\
\hline & $\mathrm{Tx}_{\mathrm{aplic}}(\% \mathrm{CDI})$ & 2,919 & 3,564 & 4,246 & 2,425 & $\mathrm{n} / \mathrm{d}$ & - & - \\
\hline & $\mathrm{Tx}_{\text {capt }}(\% \mathrm{CDI})$ & 1,370 & 0,950 & 1,377 & 0,202 & $\mathrm{n} / \mathrm{d}$ & - & - \\
\hline & Spread (\% a.a.) & 0,197 & 0,311 & 0,349 & 0,265 & $\mathrm{n} / \mathrm{d}$ & - & - \\
\hline
\end{tabular}

A Tabela 21 apresenta o teste de Kruscal Wallis para as médias encontradas em cada um dos clusters, agrupados segundo a tipologia. 
Tabela 21 - Teste de Kruscal Wallis para igualdade de médias: variáveis agrupadas por tipologia e cluster

\begin{tabular}{|c|c|c|c|c|c|c|c|}
\hline Tipologia & Estatística & $\frac{\text { Imob }}{\text { PL }}$ & $\frac{\text { Desp }_{\text {adm }}}{\text { AT }}$ & Mix & $\mathbf{T} \mathbf{x}_{\text {aplic }}$ & $\mathbf{T} \mathbf{x}_{\text {capt }}$ & Spread \\
\hline \multirow{3}{*}{$\begin{array}{l}\text { Banco } \\
\text { Comercial }\end{array}$} & $\chi^{2}$ & 15,990 & 24,115 & 13,958 & 11,245 & 5,186 & 2,853 \\
\hline & df & 6 & 6 & 6 & 6 & 6 & 6 \\
\hline & Sig. & 0,014 & 0,000 & 0,030 & 0,081 & 0,520 & 0,827 \\
\hline \multirow{3}{*}{$\begin{array}{l}\text { Banco de } \\
\text { Investimento }\end{array}$} & $\chi^{2}$ & 0,861 & 8,673 & 0,584 & 0,240 & 3,453 & 4,988 \\
\hline & df & 3 & 3 & 3 & 3 & 3 & 3 \\
\hline & Sig. & 0,835 & 0,034 & 0,900 & 0,971 & 0,327 & 0,173 \\
\hline \multirow{3}{*}{ Financeira } & $\chi^{2}$ & 0,083 & 1,333 & 0,500 & 0,214 & 0,857 & 0,000 \\
\hline & $\mathrm{df}$ & 1 & 1 & 1 & 1 & 1 & 1 \\
\hline & Sig. & 0,773 & 0,248 & 0,480 & 0,643 & 0,355 & 1,000 \\
\hline \multirow{3}{*}{$\begin{array}{l}\text { Crédito } \\
\text { imobiliário }\end{array}$} & $\chi^{2}$ & 3,442 & 2,252 & 7,316 & 0,942 & 7,117 & 0,987 \\
\hline & $\mathrm{df}$ & 4 & 4 & 4 & 3 & 3 & 3 \\
\hline & Sig. & 0,487 & 0,689 & 0,120 & 0,815 & 0,068 & 0,804 \\
\hline
\end{tabular}

Os seguintes resultados podem ser observados:

- Para os bancos com carteira comercial rejeita-se a igualdade das médias no que tange ao nível de imobilização, na relação entre despesas administrativas e o ativo total, e na proporção das receitas com serviços. Estatisticamente, as taxas médias de aplicação, captação e o spread são iguais.

- Para os bancos de investimento rejeita-se a igualdade de média apenas para a relação entre despesas e o ativo total.

- Para as sociedades de crédito imobiliário aceita-se a igualdade de médias para todas as variáveis.

- Para as financeiras aceita-se a igualdade de médias para todas as variáveis.

Os gráficos a seguir baseiam-se nos valores da Tabela 20. A numeração no eixo das abcissas refere-se ao cluster. Pode-se, no entanto, com base no teste de médias da Tabela 21, inferir se as tendências são ou não significantes. 
Imob / PL

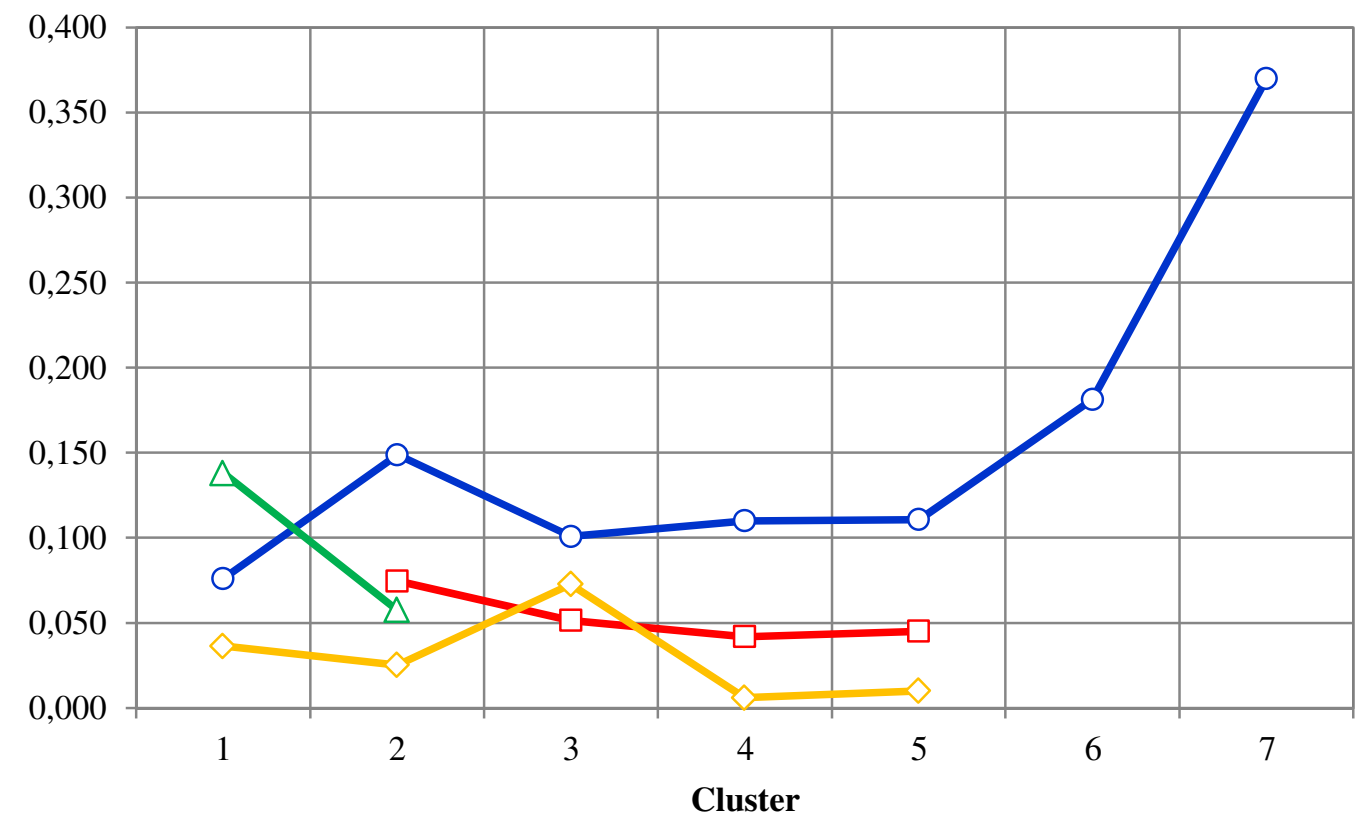

$\triangle$-Banco $\quad \square-$ Banco Invest. $\quad \triangle$ Cred. Imob. $\leadsto$ Financeira

Gráfico 9 - Influência do tamanho na relação entre o imobilizado e o patrimônio líquido

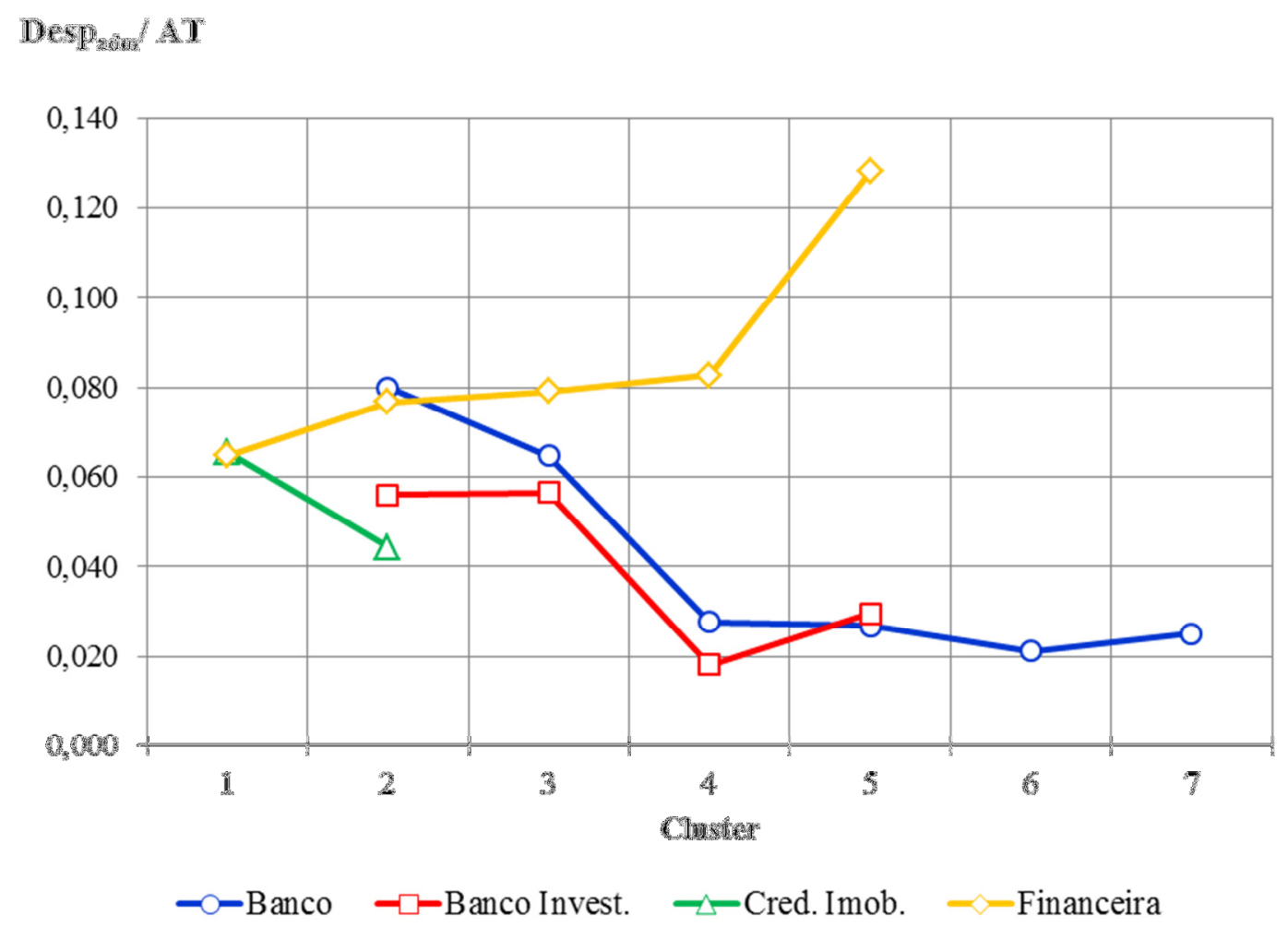

Gráfico 10 - Influência do tamanho na relação entre a despesa administrativa e o ativo total 
Mix

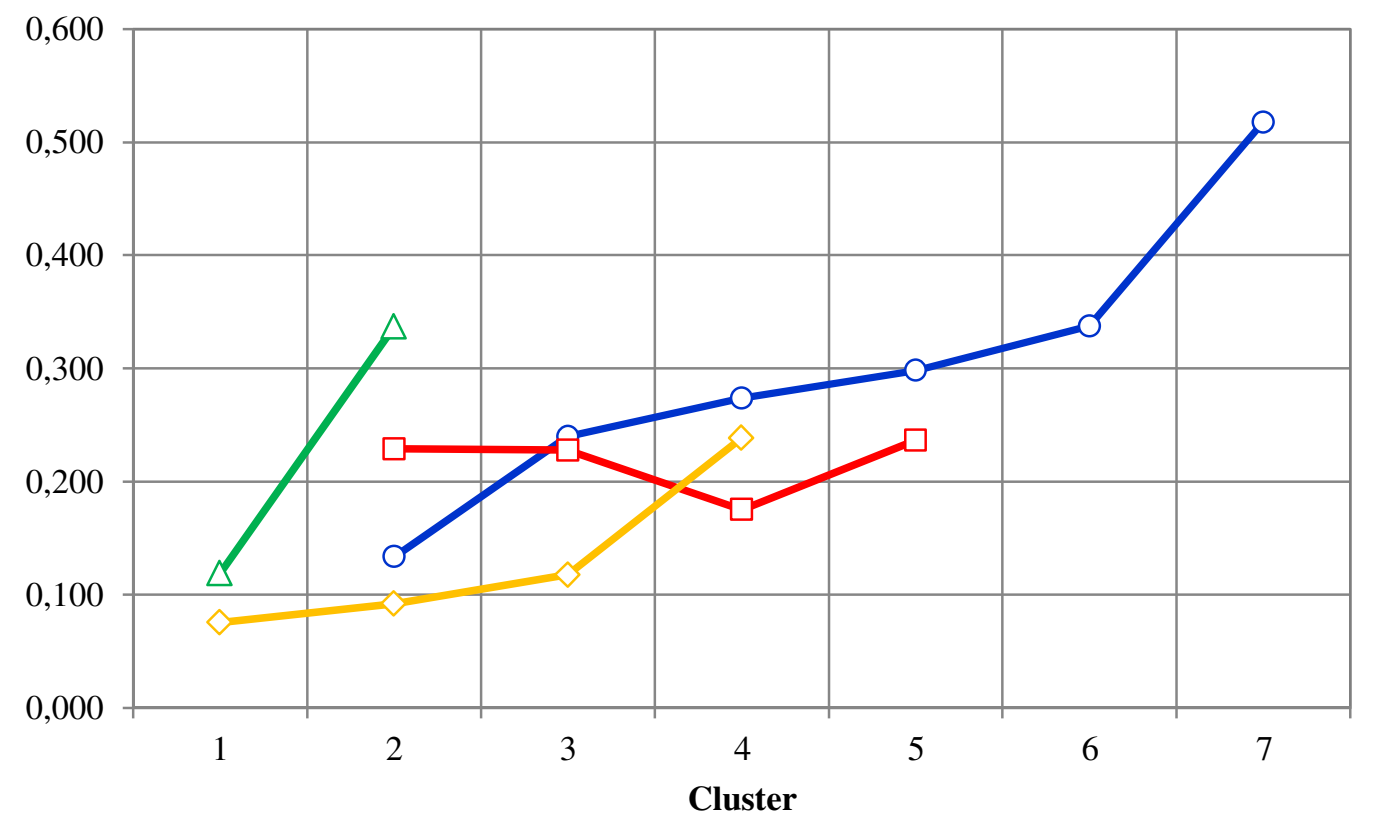

- Banco $\quad-\square-$ Banco Invest. $\quad-\triangle$ Cred. Imob. $\quad \prec$ Financeira

Gráfico 11 - Influência do tamanho na proporção de receitas com serviços no resultado

\section{Spread}

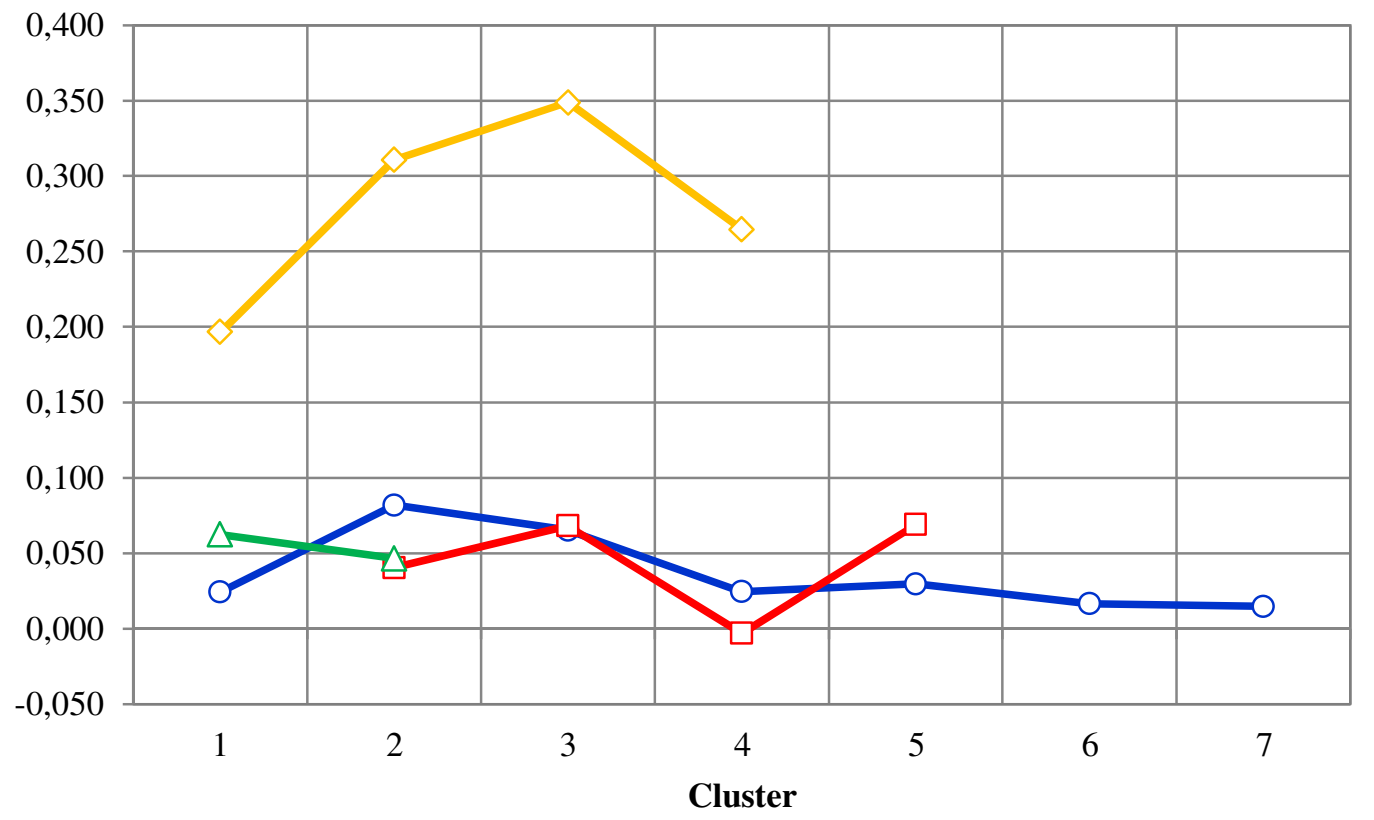

$-\infty$ Banco $\quad \square-$ Banco Invest. $\quad-\leftarrow$ Cred. Imob. $\quad \prec$ Financeira

Gráfico 12 - Influência do tamanho no spread médio 


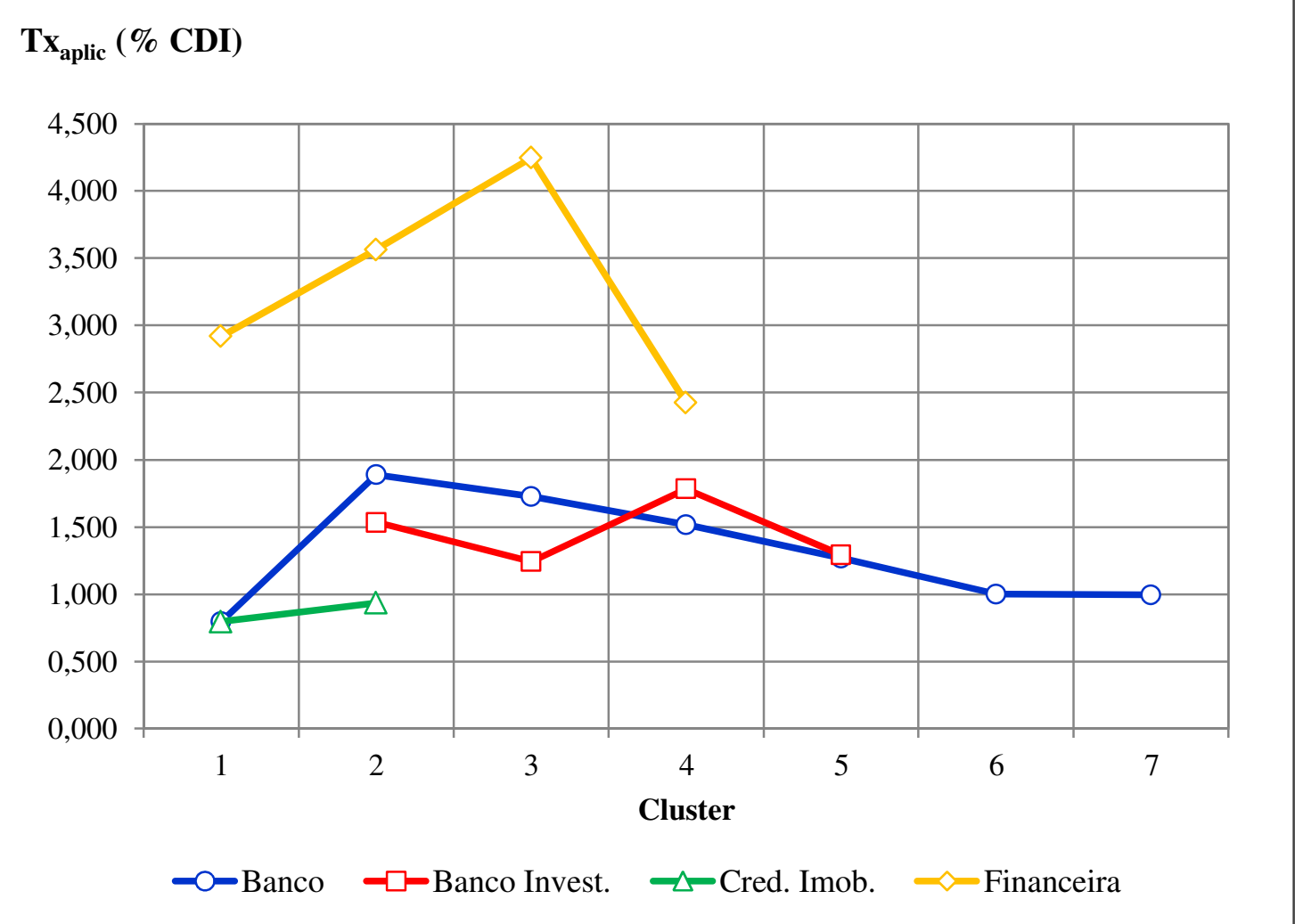

Gráfico 13 - Influência do tamanho na taxa média de aplicação

\section{$\mathrm{Tx}_{\mathrm{capt}}(\% \mathrm{CDI})$}

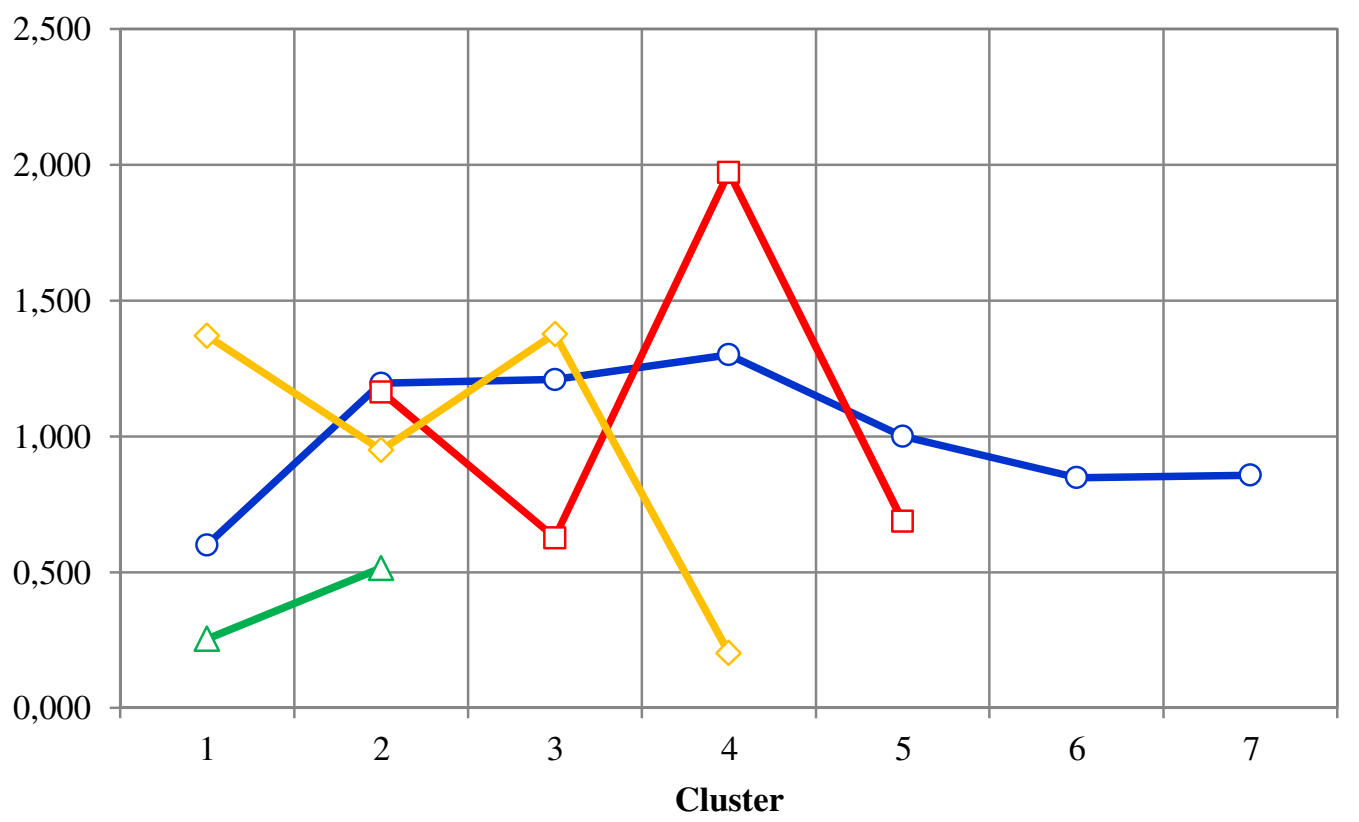

- Banco $\quad-\square-$ Banco Invest. $\quad-\neg$ Cred. Imob. $\quad \prec$ Financeira

Gráfico 14 - Influência do tamanho na taxa média de captação 
A análise destas figuras dá pistas de que, no caso exclusivo dos bancos, o retorno da instituição pode estar correlacionado ao seu porte. A análise do Gráfico 10 (despesa administrativa / ativo total) indica que isto aparenta ser verdadeiro, embora o Gráfico 12 (spread) indique o oposto. Para as demais tipologias de instituição estes diagramas aparentam não indicar a existência de correlação entre retorno e porte. Note-se também que, para os bancos comerciais, a proporção de receita com serviços é diretamente proporcional ao porte da instituição (Gráfico 11).

A Tabela 22 apresenta o teste de Kruscal Wallis para as médias, com as instituições agrupadas segundo seu respectivo cluster, independentemente da tipologia. Pode-se observar que, à exceção da taxa de captação, deve-se rejeitar a igualdade de médias para outras variáveis. Isto significa que instituições de diferentes tipos e de mesmo porte apresentam diferenças no tocante ao nível de imobilização, despesas administrativas, proporção de serviços no resultado, taxa de aplicação e spread. Esta constatação reforça a justificativa que, no modelo econométrico, a avaliação das elasticidades contemple o tipo de instituição financeira.

Tabela 22 - Teste de Kruscal Wallis para a igualdade de médias: variáveis agrupadas por cluster

\begin{tabular}{|c|c|c|c|c|c|c|}
\hline Estatística & $\frac{\text { Imob }}{\text { PL }}$ & $\frac{\text { Desp }_{\text {adm }}}{\text { AT }}$ & Mix & $T \mathbf{x}_{\text {aplic }}$ & $\mathbf{T} \mathbf{x}_{\text {capt }}$ & Spread \\
\hline$\chi^{2}$ & 23,842 & 41,404 & 24,378 & 20,731 & 4,156 & 25,570 \\
\hline df & 6 & 6 & 6 & 6 & 6 & 6 \\
\hline Sig. & 0,001 & 0,000 & 0,000 & 0,002 & 0,656 & 0,000 \\
\hline
\end{tabular}

\subsection{Estatísticas descritivas das variáveis do modelo de regressão}

Previamente ao cálculo das correlações entre ROE e porte da instituição, faz-se necessário analisar as variáveis do modelo econométrico ainda não vistas: o ROE e a alavancagem bancária.

A Tabela 23 apresenta a estatística descritiva destas variáveis. Foram consideradas as informações provenientes dos demonstrativos financeiros de junho de 2010 a dezembro de 2014. Pode-se notar que o retorno das financeiras é, em média, muito superior ao dos bancos comerciais e de investimento, o que é em parte justificado pela maior taxa de aplicação destas companhias apontadas na Tabela 13. Considerando que o porte das financeiras também é 
menor (Tabela 12), pode-se pressupor que elas sejam viáveis com um patrimônio líquido menor.

Tabela 23 - Estatísticas descritivas: ROE e alavancagem bancária

\begin{tabular}{|c|c|c|c|c|c|}
\hline \multirow[b]{2}{*}{ Variável } & \multirow[b]{2}{*}{ Estatística } & \multicolumn{4}{|c|}{ Tipo } \\
\hline & & $\begin{array}{c}\text { Banco } \\
\text { comercial }\end{array}$ & $\begin{array}{c}\text { Banco de } \\
\text { Investimento }\end{array}$ & Financeira & $\begin{array}{l}\text { Soc. de } \\
\text { Crédito } \\
\text { Imobiliário }\end{array}$ \\
\hline \multirow{5}{*}{$R O E$} & $\mathrm{~N}^{\circ}$ de observações & 919 & 317 & 298 & 80 \\
\hline & Média & 0,067 & 0,094 & 0,276 & 0,060 \\
\hline & Desvio padrão & 0,195 & 0,168 & 0,628 & 0,285 \\
\hline & Máximo & 1,202 & 1,045 & 6,789 & 1,654 \\
\hline & Mínimo & $-0,962$ & $-0,581$ & $-0,888$ & $-0,867$ \\
\hline \multirow{5}{*}{ alavanc } & $\mathrm{N}^{\mathrm{o}}$ de observações & 920 & 317 & 258 & 34 \\
\hline & Média & 0,539 & 0,532 & 0,485 & 0,341 \\
\hline & Desvio padrão & 0,264 & 0,250 & 0,293 & 0,198 \\
\hline & Máximo & 2,558 & 0,965 & 1,375 & 0,734 \\
\hline & Mínimo & 0,013 & 0,023 & 0,010 & 0,074 \\
\hline
\end{tabular}

Os bancos comerciais apresentam a segunda menor média para o ROE, e seu porte é superior aos demais. Desta forma, espera-se que seu valor do patrimônio liquido mínimo seja o maior.

Deve-se notar também a existência de valores extremos, como por exemplo, uma financeira com ROE de $678 \%$ a.a. A existência de dispersão desta monta afeta o resultado e recomenda que se proceda a um filtro na base de dados, o que será visto mais a frente.

No tocante a alavancagem, bancos comerciais e de investimento utilizam pouco mais de $50 \%$ do capital para fins regulatórios. Em seguida estão as financeiras, com pouco menos do que $50 \%$. As sociedades de crédito imobiliário são as que menos alavancam. A constatação que as financeiras alavancam menos do que bancos comerciais, mesmo que por uma pequena margem, é surpreendente, uma vez que o modelo de negócio delas é muito mais dependente da concessão de crédito do que os bancos comerciais, que tem receitas com tarifas e serviços mais expressivas.

Observa-se também que existem financeiras e bancos comerciais desenquadrados no que tange ao capital regulatório, pois apresentam alavancagem máxima superior a 100\%. 
A Tabela 24 apresenta a evolução do ROE ao longo dos semestres, por tipologia. A título de exemplo, pode-se notar que, no caso dos bancos comerciais, o ano de 2010 foi o que proporcionou maior retorno. A variação do ROE médio pode indicar que existem fatores conjunturais que podem ser benéficos ou maléficos a uma modalidade de instituição financeira.

Tabela 24 - Evolução semestral do ROE

\begin{tabular}{|c|c|c|c|c|c|}
\hline & Semestre & Banco Comercial & $\begin{array}{c}\text { Banco de } \\
\text { Investimento }\end{array}$ & Financeira & $\begin{array}{l}\text { Soc. de Crédito } \\
\text { Imobiliário }\end{array}$ \\
\hline $1^{\mathrm{o}}$ & $1^{\circ} \mathrm{Sem} 2010$ & 0,1211 & 0,0785 & - & - \\
\hline $2^{\circ}$ & $2^{\circ} \mathrm{Sem} 2010$ & 0,1004 & 0,1939 & - & - \\
\hline $3^{\circ}$ & $1^{\circ} \mathrm{Sem} 2011$ & 0,0922 & 0,1042 & 0,1183 & 0,1278 \\
\hline $4^{\circ}$ & $2^{\circ} \mathrm{Sem} 2011$ & 0,0842 & 0,1479 & 0,4187 & 0,0676 \\
\hline $5^{\circ}$ & $1^{\circ} \mathrm{Sem} 2012$ & 0,0576 & 0,0388 & 0,2723 & $-0,0449$ \\
\hline $6^{\circ}$ & $2^{\circ} \mathrm{Sem} 2012$ & 0,0617 & 0,0927 & 0,2352 & 0,3560 \\
\hline $7^{\circ}$ & $1^{\circ} \mathrm{Sem} 2013$ & 0,0361 & 0,0273 & 0,2351 & 0,0258 \\
\hline $8^{\circ}$ & $2^{\circ} \mathrm{Sem} 2013$ & 0,0293 & 0,0694 & 0,2764 & 0,0399 \\
\hline $9^{\circ}$ & $1^{\circ} \mathrm{Sem} 2014$ & 0,0360 & 0,0892 & 0,2658 & $-0,0387$ \\
\hline $10^{\circ}$ & $2^{\circ} \mathrm{Sem} 2014$ & 0,0508 & 0,0993 & 0,3659 & $-0,0699$ \\
\hline
\end{tabular}

A Tabela 25 mostra que não se pode considerar que as médias semestrais sejam iguais, para bancos e financeiras. No caso das sociedades de crédito imobiliário, os resultados mostram a estabilidade do ROE. Os bancos de investimento estão em posição limítrofe. Logo, a inserção de variáveis dummies no modelo econométrico fará com que a flutuação do ROE, em função do cenário, possa ser filtrada.

Tabela 25 - Teste de Kruscal Walis para igualdade de médias: ROE agrupado por semestre

\begin{tabular}{lccrc}
\hline & Banco Comercial & $\begin{array}{c}\text { Banco de } \\
\text { Investimento }\end{array}$ & Financeira & $\begin{array}{c}\text { Soc. de Crédito } \\
\text { Imobiliário }\end{array}$ \\
\hline Chi-Square & 23,550 & 16,231 & 17,063 & 7,470 \\
df & 9 & 9 & 7 & 7 \\
Asymp. Sig. & 0,005 & 0,062 & 0,017 & 0,382 \\
\hline
\end{tabular}

\subsubsection{Exclusão das instituições com retornos extremos}

Sobre a necessidade de se retirar da amostra as instituições que apresentaram valores de ROE extremos, é importante discorrer sobre as situações causadoras deste fenômeno. Retornos 
excepcionalmente altos podem ser provenientes de situações atípicas, decorrentes da apuração de grande resultado não operacional, como por exemplo na venda de subsidiárias. Além disto, podem existir situações em que uma instituição gera retornos sistematicamente elevados, em função de uma vantagem competitiva não detida pelas demais. A manutenção destes registros pode fazer com que se subestime o valor do patrimônio líquido mínimo.

Por outro lado, existem situações de ROE negativo muito elevado, pontualmente ou sistematicamente. Dentre as instituições da base de dados, existem algumas que podem estar enfrentando problemas, de ordem econômica ou administrativa, o que pode vir a desarticulálas e comprometer suas capacidades de se manterem operantes. Uma vez que este trabalho dedica-se a pesquisar sobre viabilidade das instituições, a inserção daquelas notadamente não viáveis pode fazer com que o valor do patrimônio líquido mínimo seja muito elevado.

Com este propósito foram analisados a média dos ROEs de cada instituição, relativo aos balanços de 2010 a 2014. O Gráfico 15 apresenta os extremos positivo e negativo do ROE médio dos bancos com carteira comercial. Pode-se notar que existem 3 instituições com ROE médio inferior a $-30 \%$ a.a., um deles inclusive foi alvo de aquisição.

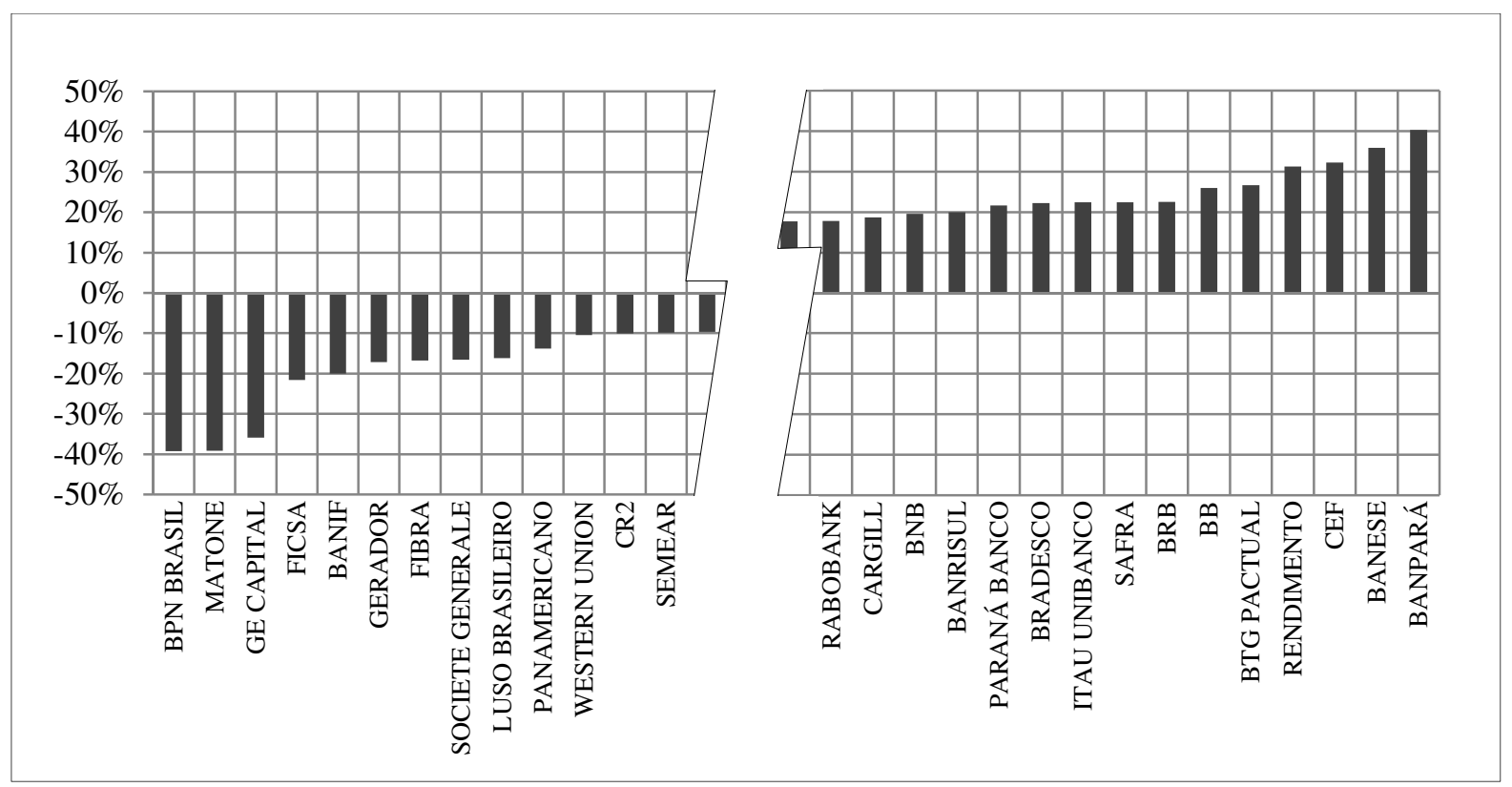

Gráfico 15 - ROE médio 2010 a 2014: bancos comerciais

O Gráfico 16 apresenta o ROE médio dos bancos com carteira de investimento. Existe uma instituição em que o ROE médio é muito superior aos demais. 


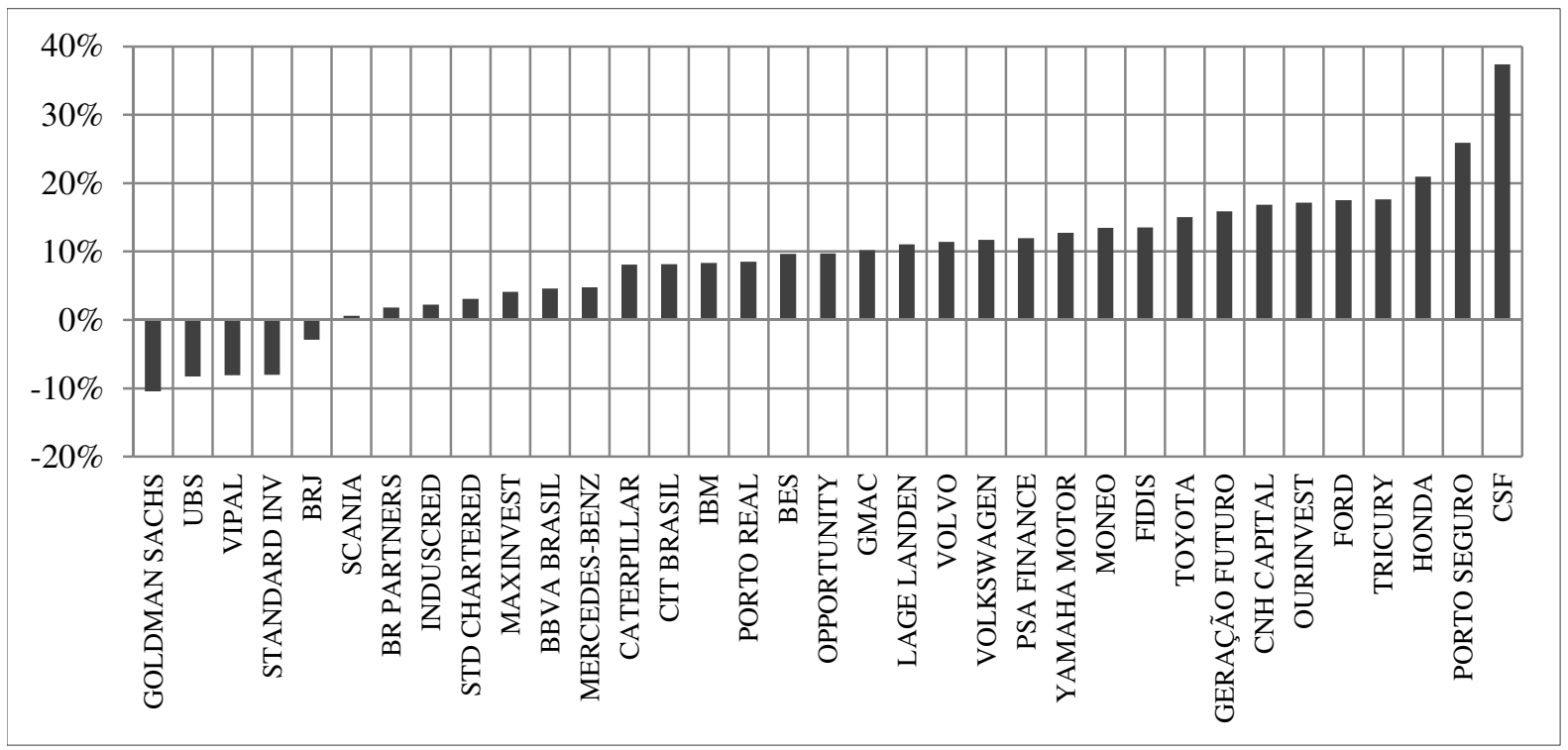

Gráfico 16 - ROE médio 2010 a 2014: bancos de investimento

No tocante às financeiras (Gráfico 17), uma delas apresentou um único balanço com ROE de $679 \%$ a.a. (que extrapola a escala do gráfico). Outras duas financeiras apresentam ROE médio superior a $100 \%$ a.a.

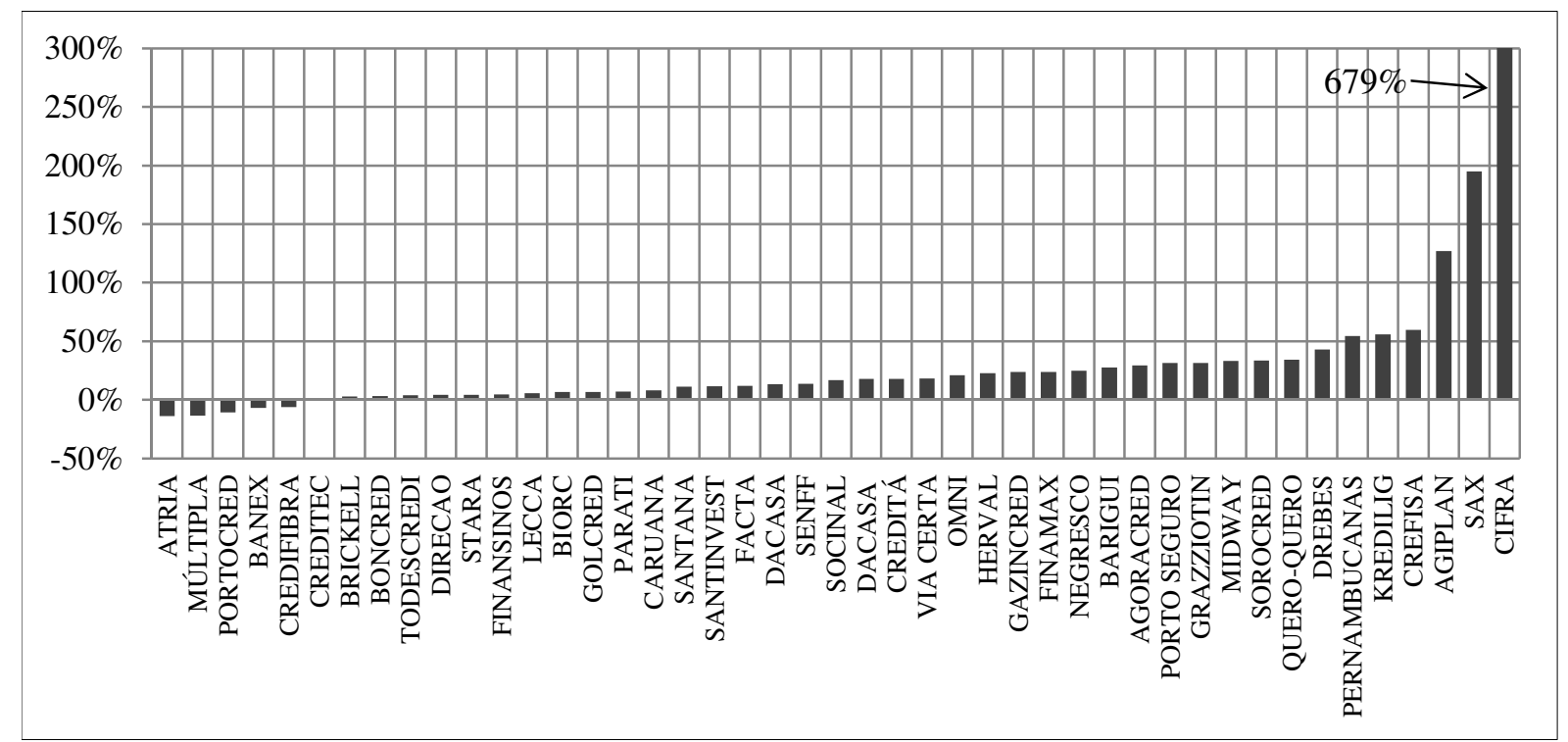

Gráfico 17 - ROE médio 2010 a 2014 : financeiras

Entre as sociedades de crédito imobiliário (Gráfico 18), uma delas apresenta ROE médio diferenciado. 


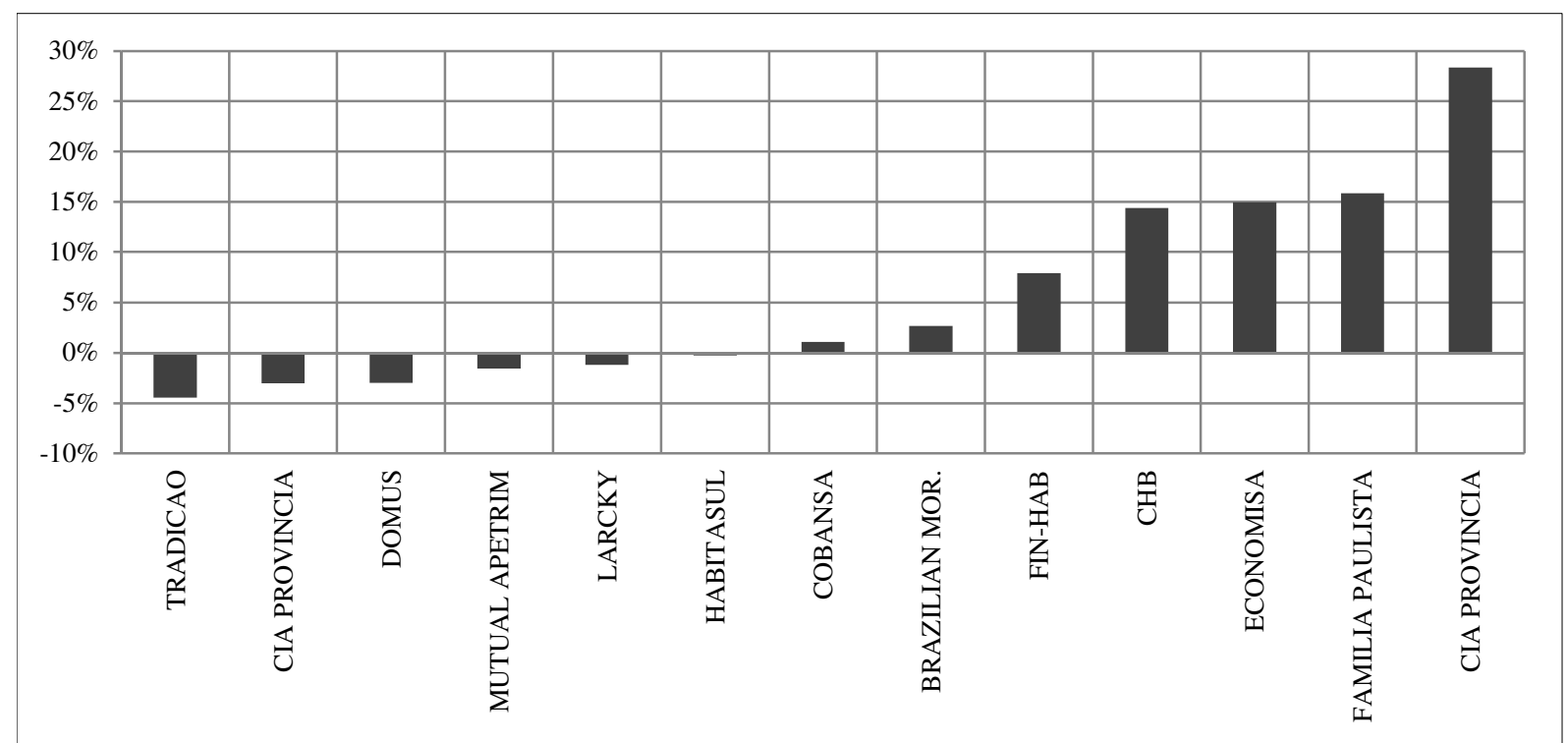

Gráfico 18 - ROE médio 2010 a 2014: sociedades de crédito imobiliário

A Tabela 26 apresenta uma análise Box-Plot para o ROE das diferentes tipologias, e define um limite inferior e superior.

Tabela 26 - Box-Plot para ROE médio

\begin{tabular}{lcccc}
\hline & $\begin{array}{c}\text { Bancos } \\
\text { Comerciais }\end{array}$ & $\begin{array}{c}\text { Bancos de } \\
\text { Investimento }\end{array}$ & Financeiras & $\begin{array}{c}\text { Soc. de Crédito } \\
\text { Imobiliário }\end{array}$ \\
\hline $1^{\circ}$ quartil & $-1,76 \%$ & $3,07 \%$ & $4,37 \%$ & $-2,26 \%$ \\
$3^{\circ}$ quartil & $13,83 \%$ & $15,05 \%$ & $31,67 \%$ & $14,68 \%$ \\
Intervalo interquartis & $15,59 \%$ & $11,98 \%$ & $27,30 \%$ & $16,94 \%$ \\
Mínimo & $-39,28 \%$ & $-10,39 \%$ & $-14,14 \%$ & $-4,43 \%$ \\
Máximo & $40,32 \%$ & $37,35 \%$ & $678,87 \%$ & $28,32 \%$ \\
Limite inferior & $-25,14 \%$ & $-10,39 \%$ & $-14,14 \%$ & $-4,43 \%$ \\
Limite superior & $37,22 \%$ & $33,03 \%$ & $72,62 \%$ & $28,32 \%$ \\
\hline
\end{tabular}

A Tabela 27 relaciona as instituições cujo ROE médio extrapola os limites da análise de BoxPlot e que com isso foram retiradas da amostra.

Tabela 27 - Instituições retiradas da amostra

\begin{tabular}{ccccc}
\hline & $\begin{array}{c}\text { Bancos } \\
\text { Comerciais }\end{array}$ & $\begin{array}{c}\text { Bancos de } \\
\text { Investimento }\end{array}$ & Financeiras & $\begin{array}{c}\text { Soc. de Crédito } \\
\text { Imobiliário }\end{array}$ \\
\hline $\begin{array}{c}\text { ROE médio abaixo } \\
\text { do limite inferior }\end{array}$ & $\begin{array}{c}\text { BNP Brasil } \\
\text { Matone } \\
\text { GE Capital }\end{array}$ & - & $\begin{array}{c}\text { Cifra } \\
\text { Sax } \\
\text { Agiplan }\end{array}$ & - \\
\hline $\begin{array}{c}\text { ROE médio acima } \\
\text { do limite inferior }\end{array}$ & Banpará & CSF & - & - \\
\hline
\end{tabular}




\subsection{Correlação entre o ROE e o porte da instituição}

A análise da correlação entre o retorno e o porte da instituição tem como objetivo responder à questão principal de pesquisa e foi detalhada na seção 4.9.1, página 63. Cada modalidade de instituição financeira foi analisada separadamente.

\subsubsection{Bancos comerciais ou múltiplos com carteira comercial}

A Tabela 28 apresenta os resultados das regressões para bancos com carteira comercial. Ao nível de significância de 5\%, o teste de Breusch e Pagan rejeita a hipótese de que as variâncias entre indivíduos sejam iguais a zero; e o teste de Schaffer e Stillman rejeita a hipótese de inexistência de correlação entre os efeitos individuais e as variáveis explicativas. Assim, o modelo adotado foi o de painel com efeitos fixos.

Como presumido, a variável $l n \_p l$ é diretamente proporcional ao ROE; e é significante ao nível de $1 \%$. A variável alavanc2 é significante ao nível de 5\%, mas alavanc é não significante.

No modelo com efeitos fixos, verificou-se que, ao se retirar a variável alavanc, alavanc2 é negativo e significante. Da mesma forma, ao se retirar alavanc2, alavanc também é negativo e significante. O modelo indicaria, portanto, que os bancos com maior ROE são os que não alavancam, o que estaria sugerindo ser prejudicial aos bancos comerciais a intermediação financeira, o que é um contrassenso. Note-se que na abordagem Pools ou com efeitos aleatórios, as variáveis alavanc e alavanc2 são significantes e respectivamente diretamente e inversamente proporcionais ao ROE, como era esperado, sugerindo existir uma alavancagem bancária ótima. Desta forma, optou-se pela retirada destas variáveis do modelo.

As regressões foram reprocessadas e os resultados são apresentados na Tabela 29. Os testes de Breusch e Pagan e de Schaffer e Stillman recomendaram a abordagem de efeitos fixos para o novo modelo. A significância de $l n \_p l$ manteve-se em $1 \%$. Quanto às dummies de tempo, o $1^{\circ}$ e o $2^{\circ}$ semestres de 2010 têm significância de $1 \%$ e apresentam o maior coeficiente positivo; portanto, estes semestres são os mais favoráveis por produzirem o menor valor de patrimônio líquido mínimo, o que está em linha com o que foi observado na Tabela 24, na página 88. 
Tabela 28 - Regressões - bancos comerciais

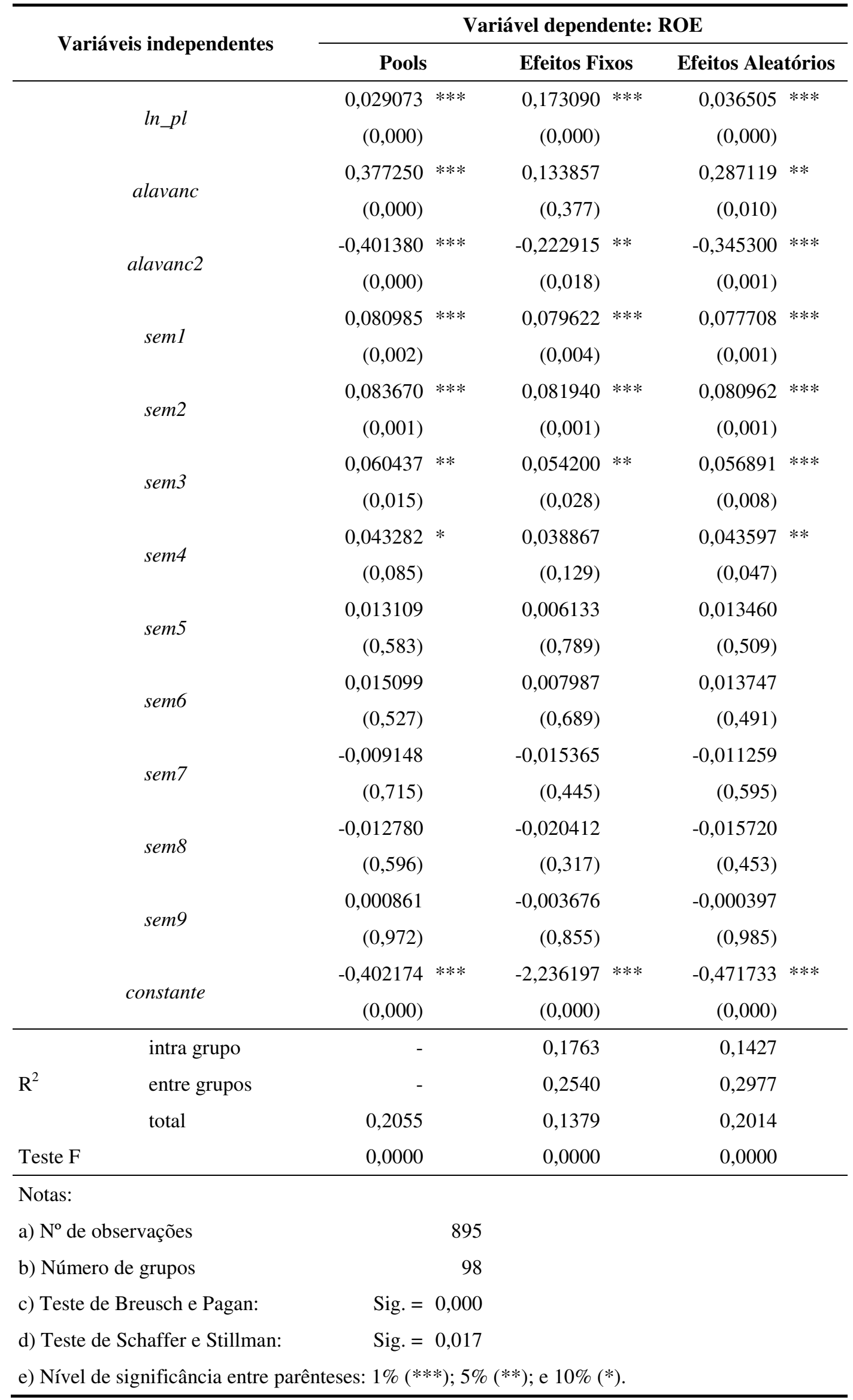


Tabela 29 - Regressões reprocessadas - bancos comerciais

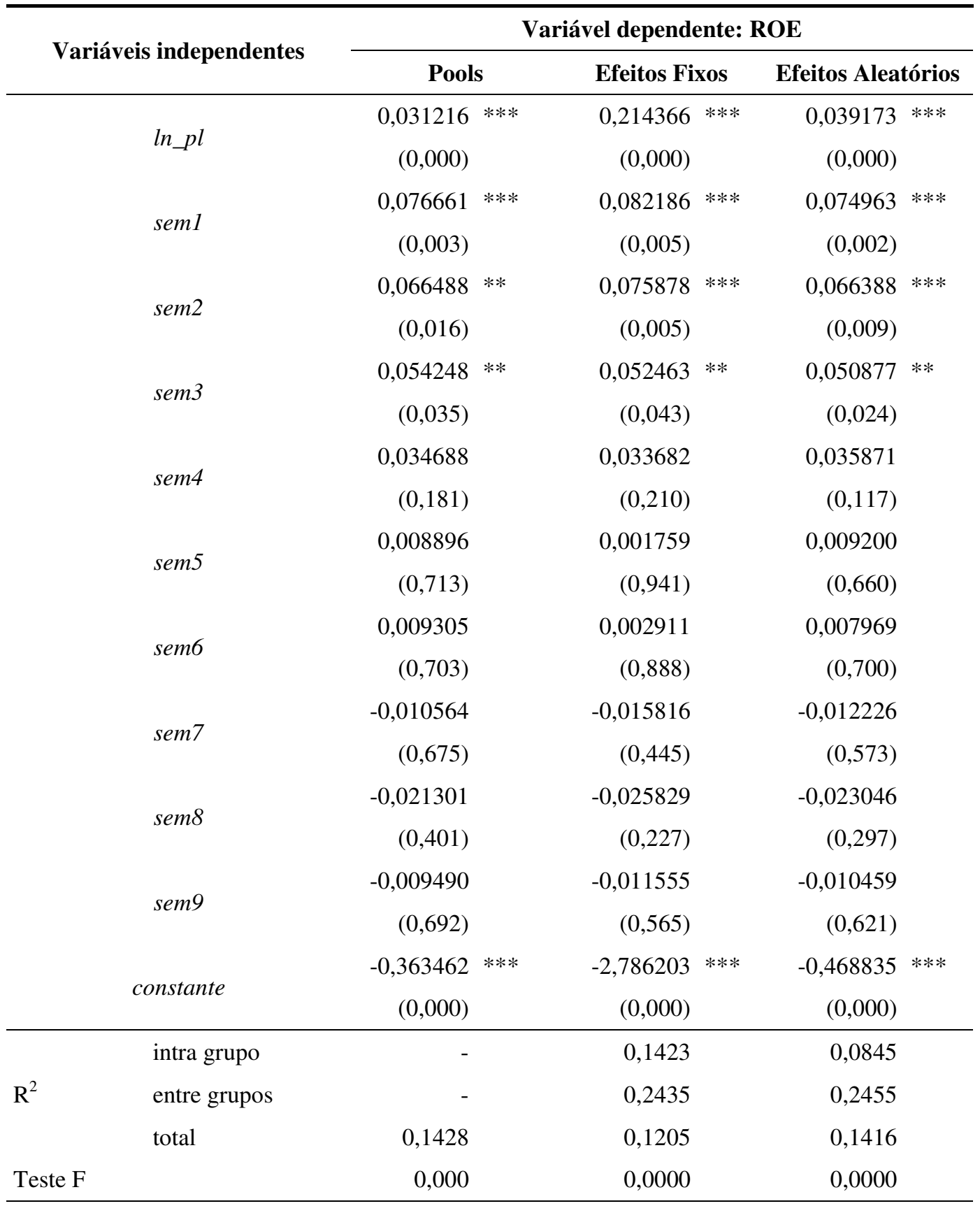

Notas:
a) $\mathrm{N}^{\mathrm{o}}$ de observações
895
b) Número de grupos
98
c) Teste de Breusch e Pagan:
Sig. $=0,000$
d) Teste de Schaffer e Stillman:
Sig. $=0,003$
e) Nível de significância entre parênteses: $1 \%(* * *) ; 5 \%(* *)$; e $10 \%(*)$.

Uma das principais premissas do MQO consiste na média condicional zero dos resíduos. A Tabela 30 mostra que, no modelo de regressão adotado para os bancos comerciais, esta média é estatisticamente igual a zero. 
Tabela 30 - Teste de média condicional zero dos resíduos - bancos comerciais

\begin{tabular}{|c|c|c|c|c|c|c|}
\hline \multirow{2}{*}{$\begin{array}{l}\text { Variável } \\
\text { Resíduo }\end{array}$} & \multirow{2}{*}{$\frac{\mathbf{N}^{\mathbf{o}} \text { obs. }}{895}$} & \multirow{2}{*}{$\begin{array}{c}\text { Média } \\
-7,71 \mathrm{E}-11\end{array}$} & \multirow{2}{*}{$\begin{array}{c}\begin{array}{c}\text { Erro } \\
\text { padrão }\end{array} \\
0,004339\end{array}$} & \multirow{2}{*}{$\begin{array}{c}\begin{array}{c}\text { Desvio } \\
\text { Padrão }\end{array} \\
0,129807\end{array}$} & \multicolumn{2}{|c|}{$\begin{array}{c}\text { Intervalo de } \\
\text { confiança de } 95 \% \\
\end{array}$} \\
\hline & & & & & $-0,008516$ & 0,008516 \\
\hline \multicolumn{2}{|c|}{ Ho: média (resíduo) $=0$} & \multicolumn{3}{|c|}{$\mathrm{t}=0$} & \multicolumn{2}{|c|}{$\mathrm{N}^{\circ}$ g.l. $=894$} \\
\hline \multicolumn{2}{|c|}{ Ha: média $<0$} & \multicolumn{3}{|c|}{ Ha: média != 0} & \multicolumn{2}{|c|}{ Ha: média >0 } \\
\hline \multicolumn{2}{|c|}{$\operatorname{Pr}(\mathrm{T}<\mathrm{t})=0,5000$} & \multicolumn{3}{|c|}{$\operatorname{Pr}(|\mathrm{T}|>|\mathrm{t}|)=1,0000$} & \multicolumn{2}{|c|}{$\operatorname{Pr}(\mathrm{T}>\mathrm{t})=0,5000$} \\
\hline
\end{tabular}

Aplicou-se também o teste de Shapiro-Francia (Tabela 31), que rejeitou a hipótese de normalidade dos termos de erro. O Gráfico 19 traz o histograma de frequência para os resíduos.

Tabela 31 - Teste de Shapiro-Francia: resíduos - bancos comerciais

\begin{tabular}{cccccc}
\hline Variável & $\mathbf{N}^{\mathbf{0}}$ obs. & $\mathbf{W}^{\mathbf{\prime}}$ & $\mathbf{V}^{\mathbf{\prime}}$ & $\mathbf{z}$ & Prob>z \\
\hline Resíduo & 895 & 0,84678 & 93,044 & 8,928 & 0,00001 \\
\hline
\end{tabular}

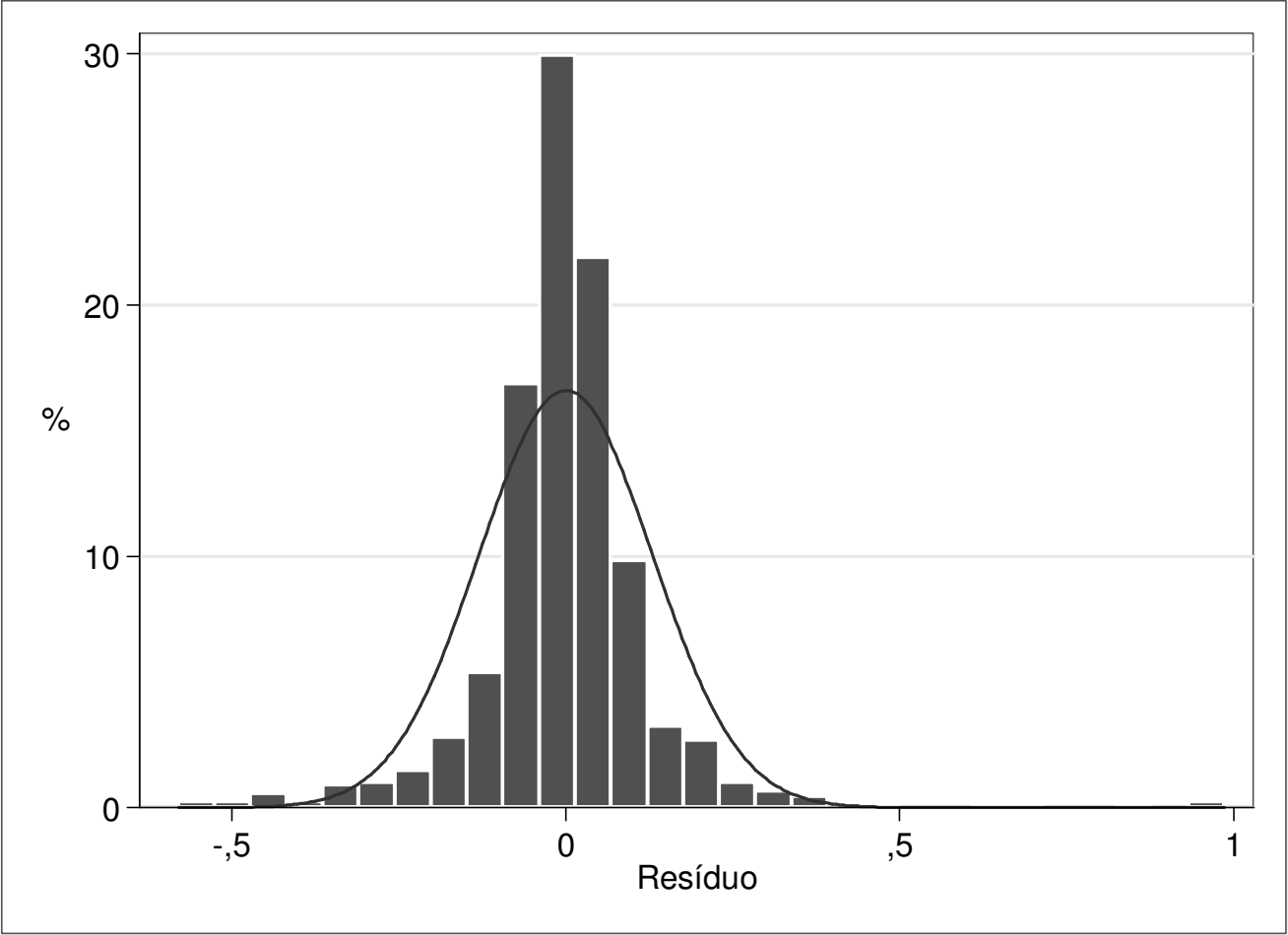

Gráfico 19 - Histograma dos resíduos - bancos comerciais

Fávero $(2015$, p. 45) cita que a normalidade dos resíduos é requerida para a validação do teste $t$ e do teste $F$. A rejeição desta premissa poderia ser, a princípio, uma limitação deste estudo. No entanto, Wooldridge (2012, p. 152, 163-165), argumenta que a violação da premissa de normalidade é minimizada quando da utilização de grandes amostras, devido às propriedades 
assintóticas dos estimadores por MQO. Desta forma, os resultados obtidos serão aceitos.

Para os bancos com carteira comercial, o modelo que explica a correlação entre o ROE e o PL é dado pela equação (11):

$$
\begin{gathered}
R O E=-2,786203+0,214366 \times \ln (p l)+0,082186 \times \operatorname{sem} 1+0,075878 \times \operatorname{sem} 2 \\
+0,052463 \times \operatorname{sem} 3
\end{gathered}
$$

\subsubsection{Bancos de investimento ou múltiplos com carteira de investimento}

A Tabela 32 apresenta as regressões para os bancos com carteira de investimento. O teste de Breusch e Pagan descarta o modelo Pools, e o teste de Schaffer e Stillman rejeita a existência de correlação entre os efeitos individuais e as variáveis independentes; desta forma, adotou-se o modelo de estimação baseado em efeitos fixos.

A variável $l n \_p l$ é significante ao nível de $5 \%$ e guarda proporcionalidade esperada com a variável dependente. As variáveis alavanc e alavanc2 não são significantes ao nível de 5\%. Quanto ao cenário, o mais favorável foi o $2^{\circ}$ semestre de 2010, com significância de 5\%, o que também está coerente com o indicado pela Tabela 24.

Na Tabela 33 são apresentados os resultados das regressões reprocessadas sem as variáveis alavanc e alavanc2. A melhor abordagem para o modelo de regressão permanece o de efeitos fixos, e a variável $l n \_p l$ é significante ao nível de $1 \%$. 
Tabela 32 - Regressões - bancos de investimento

\begin{tabular}{|c|c|c|c|c|c|}
\hline \multirow{2}{*}{ Variáveis independentes } & \multicolumn{5}{|c|}{ Variável dependente: ROE } \\
\hline & \multicolumn{2}{|l|}{ Pools } & Efeitos Fixos & \multicolumn{2}{|c|}{ Efeitos Aleatórios } \\
\hline \multirow{2}{*}{$l n \_p l$} & 0,018424 & $*$ & $0,177990 * *$ & 0,023469 & $*$ \\
\hline & $(0,064)$ & & $(0,012)$ & $(0,052)$ & \\
\hline \multirow{2}{*}{ alavanc } & 0,325235 & $*$ & 0,191454 & 0,272406 & \\
\hline & $(0,093)$ & & $(0,475)$ & $(0,197)$ & \\
\hline \multirow{2}{*}{ alavanc 2} & $-0,345119$ & $*$ & $-0,225889$ & $-0,315757$ & $*$ \\
\hline & $(0,055)$ & & $(0,332)$ & $(0,098)$ & \\
\hline \multirow{2}{*}{ seml } & 0,002174 & & 0,020952 & $-0,004176$ & \\
\hline & $(0,957)$ & & $(0,530)$ & $(0,912)$ & \\
\hline \multirow{2}{*}{ sem2 } & 0,112445 & $* *$ & $0,114740 * *$ & 0,105618 & $* *$ \\
\hline & $(0,043)$ & & $(0,031)$ & $(0,045)$ & \\
\hline \multirow{2}{*}{ sem3 } & 0,024579 & & 0,026191 & 0,021914 & \\
\hline & $(0,399)$ & & $(0,375)$ & $(0,413)$ & \\
\hline \multirow{2}{*}{ sem4 } & 0,057077 & & 0,056490 & 0,055095 & \\
\hline & $(0,142)$ & & $(0,210)$ & $(0,143)$ & \\
\hline \multirow{2}{*}{ sem5 } & $-0,055927$ & & $-0,050997 *$ & $-0,056055$ & $*$ \\
\hline & $(0,130)$ & & $(0,056)$ & $(0,098)$ & \\
\hline \multirow{2}{*}{ sem6 } & $-0,006154$ & & $-0,005789$ & $-0,007757$ & \\
\hline & $(0,840)$ & & $(0,855)$ & $(0,784)$ & \\
\hline \multirow{2}{*}{$\operatorname{sem} 7$} & $-0,067129$ & $* *$ & $-0,059142 * *$ & $-0,067320$ & $* *$ \\
\hline & $(0,032)$ & & $(0,044)$ & $(0,020)$ & \\
\hline \multirow{2}{*}{ sem8 } & $-0,023444$ & & $-0,013999$ & $-0,022401$ & \\
\hline & $(0,500)$ & & $(0,670)$ & $(0,500)$ & \\
\hline \multirow{2}{*}{$\operatorname{sem} 9$} & $-0,012384$ & & $-0,009092$ & $-0,012190$ & \\
\hline & $(0,661)$ & & $(0,727)$ & $(0,646)$ & \\
\hline \multirow{2}{*}{ constante } & $-0,198294$ & & $-2,140064 * *$ & $-0,241175$ & \\
\hline & $(0,110)$ & & $(0,011)$ & $(0,110)$ & \\
\hline \multirow{3}{*}{ entre grupos } & - & & 0,1806 & 0,1269 & \\
\hline & - & & 0,0231 & 0,0797 & \\
\hline & 0,1212 & & 0,0373 & 0,1194 & \\
\hline Teste F & 0,0000 & & 0,0001 & 0,0000 & \\
\hline \multicolumn{6}{|l|}{ Notas: } \\
\hline a) $\mathrm{N}^{\circ}$ de observações & \multicolumn{3}{|c|}{307} & & \\
\hline b) Número de grupos & \multicolumn{3}{|c|}{34} & & \\
\hline c) Teste de Breusch e Pagan: & \multicolumn{2}{|c|}{ Sig. $=0,000$} & & & \\
\hline d) Teste de Schaffer e Stillman: & Sig. $=$ & 0,002 & & & \\
\hline e) Nível de significância entre pa & eses: $1 \%(* *$ & $*) ; 5 \%$ & $*) ;$ e $10 \%(*)$ & & \\
\hline
\end{tabular}


Tabela 33 - Regressões reprocessadas - bancos de investimento

\begin{tabular}{|c|c|c|c|c|c|c|}
\hline \multirow{2}{*}{ Variáveis independentes } & \multicolumn{6}{|c|}{ Variável dependente: ROE } \\
\hline & \multicolumn{2}{|l|}{ Pools } & \multicolumn{2}{|c|}{ Efeitos Fixos } & \multicolumn{2}{|c|}{ Efeitos Aleatórios } \\
\hline \multirow{2}{*}{$l n \_p l$} & 0,017268 & $* *$ & 0,190167 & $* * *$ & 0,021075 & $* *$ \\
\hline & $(0,026)$ & & $(0,007)$ & & $(0,048)$ & \\
\hline \multirow{2}{*}{ seml } & $-0,006430$ & & 0,019304 & & $-0,014135$ & \\
\hline & $(0,875)$ & & $(0,568)$ & & $(0,711)$ & \\
\hline \multirow{2}{*}{ sem2 } & 0,109431 & $* *$ & 0,115603 & $* *$ & 0,101294 & $* *$ \\
\hline & $(0,046)$ & & $(0,026)$ & & $(0,048)$ & \\
\hline \multirow{2}{*}{ sem3 } & 0,022188 & & 0,026113 & & 0,018586 & \\
\hline & $(0,438)$ & & $(0,363)$ & & $(0,468)$ & \\
\hline \multirow{2}{*}{ sem4 } & 0,058240 & & 0,057997 & & 0,054547 & \\
\hline & $(0,128)$ & & $(0,177)$ & & $(0,138)$ & \\
\hline \multirow{2}{*}{ sem5 } & $-0,052777$ & & $-0,049035$ & $*$ & $-0,055019$ & $*$ \\
\hline & $(0,152)$ & & $(0,054)$ & & $(0,097)$ & \\
\hline \multirow{2}{*}{ sem6 } & $-0,005075$ & & $-0,004734$ & & $-0,007826$ & \\
\hline & $(0,866)$ & & $(0,876)$ & & $(0,772)$ & \\
\hline \multirow{2}{*}{$\operatorname{sem} 7$} & $-0,065406$ & $* *$ & $-0,057520$ & $* *$ & $-0,066597$ & $* *$ \\
\hline & $(0,037)$ & & $(0,047)$ & & $(0,018)$ & \\
\hline \multirow{2}{*}{ sem 8} & $-0,024482$ & & $-0,014810$ & & $-0,024273$ & \\
\hline & $(0,477)$ & & $(0,655)$ & & $(0,456)$ & \\
\hline \multirow{2}{*}{$\operatorname{sem} 9$} & $-0,009476$ & & $-0,008336$ & & $-0,010701$ & \\
\hline & $(0,732)$ & & $(0,750)$ & & $(0,675)$ & \\
\hline \multirow{2}{*}{ constante } & $-0,130377$ & & $-2,267360$ & $* * *$ & $-0,174877$ & \\
\hline & $(0,202)$ & & $(0,009)$ & & $(0,210)$ & \\
\hline \multirow{3}{*}{ entre grupos } & - & & 0,1752 & & 0,1090 & \\
\hline & - & & 0,0233 & & 0,1030 & \\
\hline & 0,1052 & & 0,0331 & & 0,1040 & \\
\hline Teste F & 0,0000 & & 0,0044 & & 0,0000 & \\
\hline \multicolumn{7}{|l|}{ Notas: } \\
\hline a) $\mathrm{N}^{\circ}$ de observações & \multicolumn{4}{|c|}{307} & & \\
\hline b) Número de grupos & \multicolumn{4}{|c|}{34} & & \\
\hline c) Teste de Breusch e Pagan: & \multicolumn{2}{|c|}{ Sig. $=0,000$} & & & & \\
\hline d) Teste de Schaffer e Stillman: & Sig. $=$ & 0,001 & & & & \\
\hline e) Nível de significância entre p & ses: $1 \%(* *$ & $*) ; 5 \%$ & *); e $10 \%(*$ & & & \\
\hline
\end{tabular}

Na Tabela 34 confirma-se que a média dos resíduos é estatisticamente igual a zero. 
Tabela 34 - Teste de média condicional zero dos resíduos - bancos de investimento

\begin{tabular}{|c|c|c|c|c|c|c|}
\hline \multirow{2}{*}{$\begin{array}{l}\text { Variável } \\
\text { Resíduo }\end{array}$} & \multirow{2}{*}{$\begin{array}{c}\mathbf{N}^{\mathbf{o}} \text { obs. } \\
307\end{array}$} & \multirow{2}{*}{$\begin{array}{c}\text { Média } \\
2,88 \mathrm{E}-11\end{array}$} & \multirow{2}{*}{$\begin{array}{c}\begin{array}{c}\text { Erro } \\
\text { padrão }\end{array} \\
0,007236\end{array}$} & \multirow{2}{*}{$\begin{array}{c}\begin{array}{c}\text { Desvio } \\
\text { Padrão }\end{array} \\
0,126789\end{array}$} & \multicolumn{2}{|c|}{$\begin{array}{c}\text { Intervalo de } \\
\text { confiança de } 95 \%\end{array}$} \\
\hline & & & & & $-0,014239$ & 0,014239 \\
\hline \multicolumn{2}{|c|}{ Ho: média $($ resíduo $)=0$} & & \multicolumn{2}{|l|}{$t=0$} & \multicolumn{2}{|c|}{$\mathrm{N}^{\mathrm{o}}$ g.l. $=306$} \\
\hline \multicolumn{2}{|c|}{ Ha: média $<0$} & \multicolumn{3}{|c|}{ Ha: média $!=0$} & \multicolumn{2}{|c|}{ Ha: média $>0$} \\
\hline \multicolumn{2}{|c|}{$\operatorname{Pr}(\mathrm{T}<\mathrm{t})=0,5000$} & \multicolumn{3}{|c|}{$\operatorname{Pr}(|\mathrm{T}|>|\mathrm{t}|)=1,0000$} & \multicolumn{2}{|c|}{$\operatorname{Pr}(\mathrm{T}>\mathrm{t})=0,5000$} \\
\hline
\end{tabular}

A Tabela 35 apresenta os resultados do teste de Shapiro-Francia; que rejeitou a normalidade dos resíduos, cujo histograma de frequência é apresentado no Gráfico 20.

Tabela 35 - Teste de Shapiro-Francia: resíduos - bancos de investimento

\begin{tabular}{cccccc}
\hline Variável & $\mathbf{N}^{\mathbf{o}}$ obs. & $\mathbf{W}^{\mathbf{1}}$ & $\mathbf{V}^{\prime}$ & $\mathbf{z}$ & Prob>z \\
\hline Resíduo & 307 & 0,85692 & 33,286 & 7,183 & 0,00001 \\
\hline
\end{tabular}

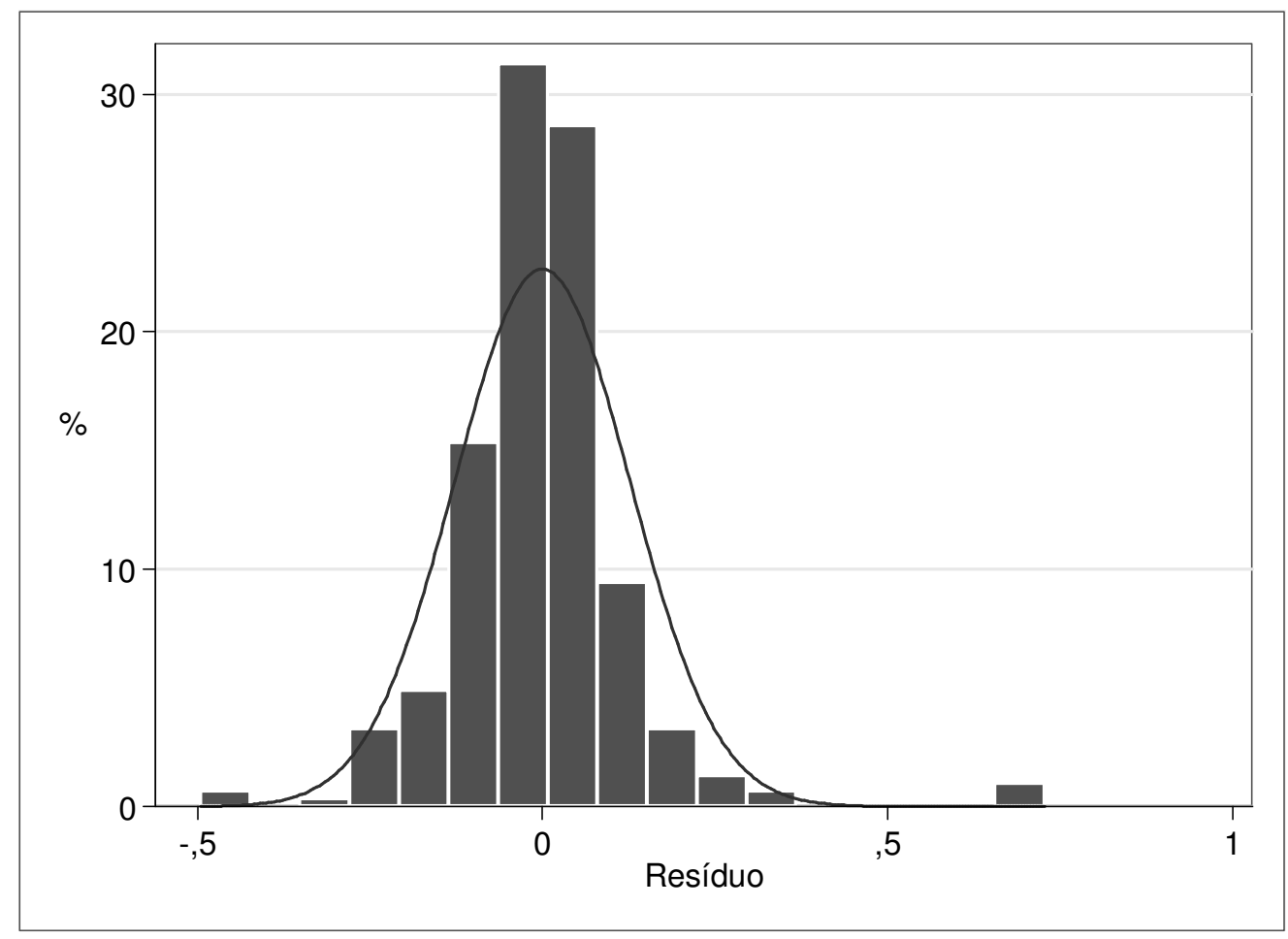

Gráfico 20 - Histograma dos resíduos - bancos de investimento

Para os bancos de investimento, o modelo que explica a correlação entre o ROE e o PL é dado pela equação (12).

$$
R O E=-2,267360+0,190167 \times \ln \_\mathrm{pl}+0,115603 \times \operatorname{sem} 2-0,057520 \times \operatorname{sem} 7
$$




\subsubsection{Financeiras}

A Tabela 36 apresenta as regressões para as financeiras. Algumas variáveis dummies foram descartadas $^{7}$, para o que foram marcadas como não disponíveis (ND). Isto decorre da inexistência de dados para o semestre correspondente.

Deve-se rejeitar a hipótese de inexistência de correlação entre efeitos individuais e as variáveis explicativas, pois o Teste de Schaffer e Stillman não é significante. Logo, o modelo de estimação será o de efeitos fixos. As variáveis $l n \_p l$ e alavanc não são significantes.

Verificou-se que, ao se retirar a variável alavanc, alavanc $^{2}$ deixa de ser significante; quando se mantém alavanc e se retira alavanc ${ }^{2}$, alavanc torna-se não significante. Nas duas situações $l n \_p l$ é não significante. Verificou-se também que ao se retirar as variáveis de alavancagem, $l n \_p l$ passou a ser significante. Esta foi a solução adotada, e os resultados são apresentados na Tabela 37. No novo modelo, os testes de Schaffer e Stillman e de Breusch e Pagan recomendam a abordagem com efeitos fixos.

\footnotetext{
${ }^{7}$ O Stata dá a indicação de dropped.
} 
Tabela 36 - Regressões - financeiras

\begin{tabular}{|c|c|c|c|c|c|}
\hline \multirow{2}{*}{ Variáveis independentes } & \multicolumn{5}{|c|}{ Variável dependente: ROE } \\
\hline & \multicolumn{2}{|l|}{ Pools } & Efeitos Fixos & \multicolumn{2}{|c|}{ Efeitos Aleatórios } \\
\hline \multirow{2}{*}{$l n \_p l$} & 0,075743 & $* * *$ & 0,130484 & 0,073382 & $* * *$ \\
\hline & $(0,000)$ & & $(0,225)$ & $(0,000)$ & \\
\hline \multirow{2}{*}{ alavanc } & 0,327101 & & 0,897035 & 0,674967 & $*$ \\
\hline & $(0,392)$ & & $(0,147)$ & $(0,085)$ & \\
\hline \multirow{2}{*}{ alavanc2 } & $-0,341011$ & & $-1,087249 * * *$ & $-0,694791$ & $*$ \\
\hline & $(0,376)$ & & $(0,003)$ & $(0,071)$ & \\
\hline seml & ND & & ND & ND & \\
\hline $\operatorname{sem} 2$ & ND & & ND & ND & \\
\hline \multirow{2}{*}{ sem3 } & $-0,136539$ & $* *$ & $-0,134093$ & $-0,137186$ & $* *$ \\
\hline & $(0,030)$ & & $(0,130)$ & $(0,025)$ & \\
\hline \multirow{2}{*}{ sem4 } & $-0,061736$ & & $-0,016262$ & $-0,047162$ & \\
\hline & $(0,475)$ & & $(0,846)$ & $(0,566)$ & \\
\hline sem5 & ND & & ND & ND & \\
\hline \multirow{2}{*}{ sem6 } & $-0,059264$ & & $-0,045737$ & $-0,055760$ & \\
\hline & $(0,347)$ & & $(0,535)$ & $(0,346)$ & \\
\hline \multirow{2}{*}{$\operatorname{sem} 7$} & $-0,063777$ & & $-0,043853$ & $-0,060203$ & \\
\hline & $(0,214)$ & & $(0,445)$ & $(0,199)$ & \\
\hline \multirow{2}{*}{$\operatorname{sem} 8$} & $-0,060667$ & & $-0,050901$ & $-0,056855$ & \\
\hline & $(0,269)$ & & $(0,493)$ & $(0,268)$ & \\
\hline \multirow{2}{*}{$\operatorname{sem} 9$} & $-0,095855$ & $*$ & $-0,081056$ & $-0,091080$ & $*$ \\
\hline & $(0,098)$ & & $(0,232)$ & $(0,093)$ & \\
\hline \multirow{2}{*}{ constante } & $-0,594113$ & $* * *$ & $-1,217100$ & $-0,626477$ & $* * *$ \\
\hline & $(0,000)$ & & $(0,342)$ & $(0,000)$ & \\
\hline \multirow{3}{*}{ entre grupos } & - & & 0,1658 & 0,1514 & \\
\hline & - & & 0,1252 & 0,1530 & \\
\hline & 0,1586 & & 0,1396 & 0,1518 & \\
\hline Teste F & 0,0000 & & 0,0000 & . & \\
\hline \multicolumn{6}{|l|}{ Notas: } \\
\hline a) $\mathrm{N}^{\mathrm{o}}$ de observações & \multicolumn{3}{|c|}{243} & & \\
\hline b) Número de grupos & \multicolumn{3}{|c|}{40} & & \\
\hline c) Teste de Breusch e Pagan: & Sig. $=$ & 0,000 & & & \\
\hline d) Teste de Schaffer e Stillman: & Sig. $=$ & 0,039 & & & \\
\hline e) Nível de significância entre $p$ & ses: $1 \%(* * *$ & $*) ; 5 \%($ & $*)$; e $10 \%(*)$ & & \\
\hline
\end{tabular}


Tabela 37 - Regressões reprocessadas - financeiras

\begin{tabular}{|c|c|c|c|c|c|c|c|}
\hline \multirow{2}{*}{\multicolumn{2}{|c|}{ Variáveis independentes }} & \multicolumn{6}{|c|}{ Variável dependente: ROE } \\
\hline & & \multicolumn{2}{|l|}{ Pools } & \multicolumn{2}{|c|}{ Efeitos Fixos } & \multicolumn{2}{|c|}{ Efeitos Aleatórios } \\
\hline \multirow{2}{*}{\multicolumn{2}{|c|}{$\ln \_p l$}} & 0,078511 & $* * *$ & 0,286166 & $* *$ & 0,079724 & $* * *$ \\
\hline & & $(0,000)$ & & $(0,012)$ & & $(0,000)$ & \\
\hline \multicolumn{2}{|r|}{ seml } & ND & & ND & & ND & \\
\hline \multicolumn{2}{|r|}{$\operatorname{sem} 2$} & ND & & ND & & ND & \\
\hline \multirow{2}{*}{\multicolumn{2}{|c|}{ sem3 }} & $-0,137572$ & $* *$ & $-0,104728$ & & $-0,142560$ & $* *$ \\
\hline & & $(0,021)$ & & $(0,125)$ & & $(0,010)$ & \\
\hline \multirow{2}{*}{\multicolumn{2}{|c|}{ sem4 }} & $-0,090825$ & & $-0,014626$ & & $-0,083667$ & \\
\hline & & $(0,286)$ & & $(0,853)$ & & $(0,297)$ & \\
\hline \multirow{2}{*}{\multicolumn{2}{|c|}{$\operatorname{sem} 5$}} & $-0,089812$ & & $-0,035457$ & & $-0,084282$ & \\
\hline & & $(0,129)$ & & $(0,489)$ & & $(0,117)$ & \\
\hline \multirow{2}{*}{\multicolumn{2}{|c|}{ sem6 }} & $-0,063345$ & & $-0,032987$ & & $-0,062827$ & \\
\hline & & $(0,307)$ & & $(0,643)$ & & $(0,268)$ & \\
\hline \multirow{2}{*}{\multicolumn{2}{|c|}{$\operatorname{sem} 7$}} & $-0,069885$ & & $-0,039887$ & & $-0,070369$ & \\
\hline & & $(0,165)$ & & $(0,469)$ & & $(0,121)$ & \\
\hline \multirow{2}{*}{\multicolumn{2}{|c|}{$\operatorname{sem} 8$}} & $-0,064909$ & & $-0,052920$ & & $-0,066541$ & \\
\hline & & $(0,234)$ & & $(0,434)$ & & $(0,187)$ & \\
\hline \multirow{2}{*}{\multicolumn{2}{|c|}{$\operatorname{sem} 9$}} & $-0,100437$ & $*$ & $-0,085153$ & & $-0,100348$ & $*$ \\
\hline & & $(0,076)$ & & $(0,170)$ & & $(0,056)$ & \\
\hline \multirow{2}{*}{\multicolumn{2}{|c|}{ constante }} & $-0,570291$ & $* * *$ & $-2,779228$ & $* *$ & $-0,587999$ & $* * *$ \\
\hline & & $(0,000)$ & & $(0,020)$ & & $(0,003)$ & \\
\hline \multirow{3}{*}{$\mathrm{R}^{2}$} & intra grupo & - & & 0,0969 & & 0,0665 & \\
\hline & entre grupos & - & & 0,1781 & & 0,1895 & \\
\hline & total & 0,1481 & & 0,1370 & & 0,1479 & \\
\hline \multicolumn{2}{|c|}{ Teste F } & 0,0000 & & 0,0005 & & - & \\
\hline
\end{tabular}

Notas:
a) $\mathrm{N}^{\mathrm{o}}$ de observações
b) Número de grupos
c) Teste de Breusch e Pagan:
Sig. $=0,000$
d) Teste de Schaffer e Stillman:
Sig. $=0,002$
e) Nível de significância entre parênteses: 1\% (***); 5\% (**); e 10\% (*).

Na Tabela 38 confirma-se que a média dos resíduos do modelo adotado para as financeiras é estatisticamente igual a zero. 
Tabela 38 - Teste de média condicional zero dos resíduos - financeiras

\begin{tabular}{|c|c|c|c|c|c|c|}
\hline \multirow{2}{*}{$\begin{array}{l}\text { Variável } \\
\text { Resíduo }\end{array}$} & \multirow{2}{*}{$\frac{\mathbf{N}^{\mathbf{o}} \text { obs. }}{281}$} & \multirow{2}{*}{$\begin{array}{c}\text { Média } \\
-3,98 \mathrm{E}-10\end{array}$} & \multirow{2}{*}{$\begin{array}{c}\begin{array}{c}\text { Erro } \\
\text { padrão }\end{array} \\
0,012912\end{array}$} & \multirow{2}{*}{$\begin{array}{c}\begin{array}{c}\text { Desvio } \\
\text { Padrão }\end{array} \\
0,216450\end{array}$} & \multicolumn{2}{|c|}{$\begin{array}{c}\text { Intervalo de } \\
\text { confiança de } 95 \%\end{array}$} \\
\hline & & & & & $-0,025418$ & 0,025418 \\
\hline \multicolumn{2}{|c|}{ Ho: média (resíduo) $=0$} & & \multicolumn{2}{|l|}{$\mathrm{t}=0$} & \multicolumn{2}{|c|}{$\mathrm{N}^{\circ}$ g.l. $=280$} \\
\hline \multicolumn{2}{|c|}{ Ha: média $<0$} & \multicolumn{3}{|c|}{ Ha: média != 0} & \multicolumn{2}{|c|}{ Ha: média > 0} \\
\hline \multicolumn{2}{|c|}{$\operatorname{Pr}(T<t)=0,5000$} & \multicolumn{3}{|c|}{$\operatorname{Pr}(|\mathrm{T}|>|\mathrm{t}|)=1,0000$} & \multicolumn{2}{|c|}{$\operatorname{Pr}(T>t)=0,5000$} \\
\hline
\end{tabular}

A hipótese de normalidade dos resíduos é rejeitada pelo Teste de Shapiro-Francia, apresentado na Tabela 39. O histograma de frequência é apresentado no Gráfico 21.

Tabela 39 - Teste de Shapiro-Francia: resíduos - financeiras

\begin{tabular}{cccccc}
\hline Variável & $\mathbf{N}^{\mathbf{0}}$ obs. & $\mathbf{W}^{\prime}$ & $\mathbf{V}^{\prime}$ & $\mathbf{z}$ & Prob $>\mathbf{z}$ \\
\hline Resíduo & 281 & 0,72678 & 58,852 & 8,218 & 0,00001 \\
\hline
\end{tabular}

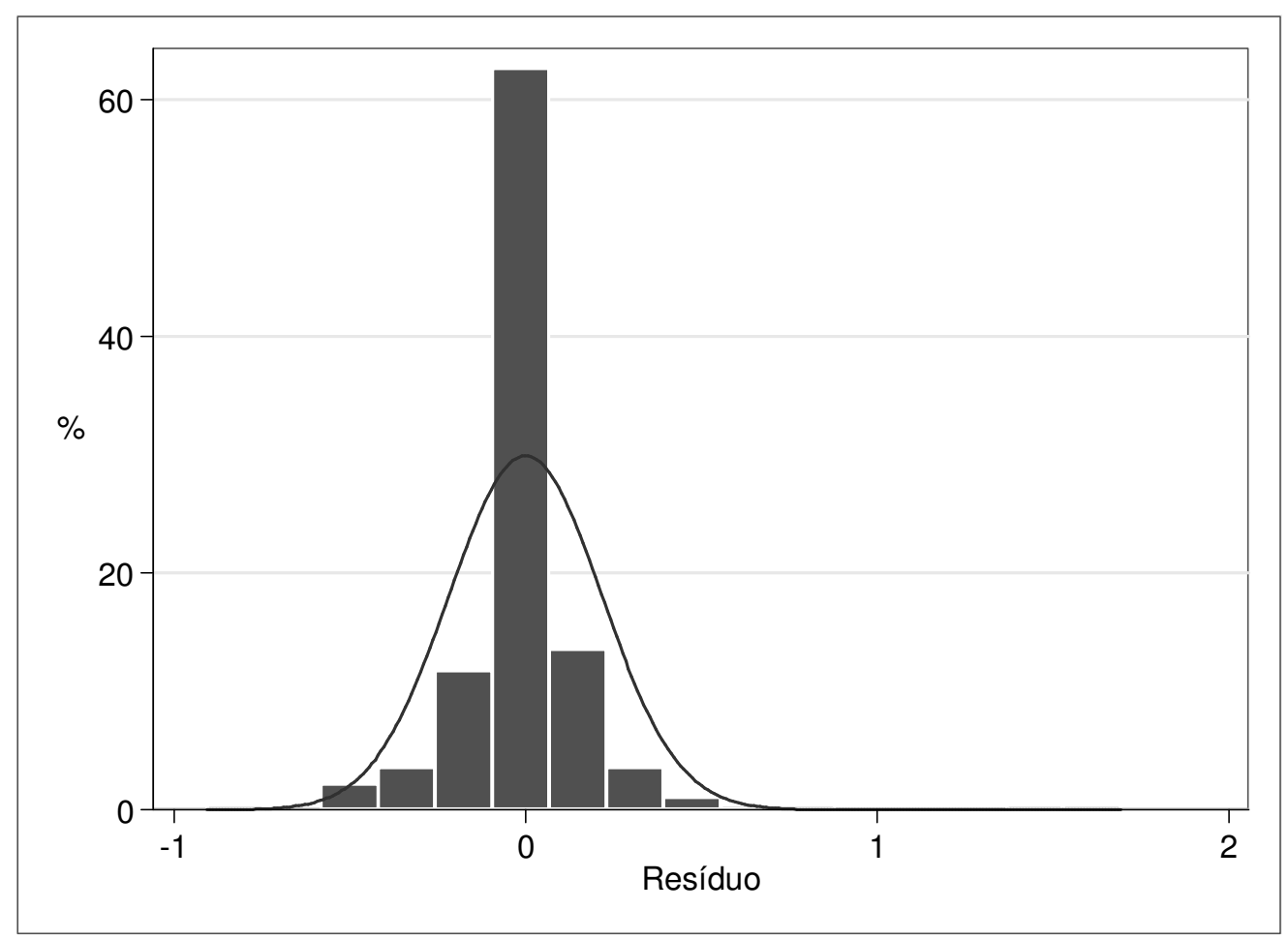

Gráfico 21 - Histograma dos erros - financeiras

O modelo que explica a correlação entre o ROE e o PL para as financeiras é dado pela equação (13):

$$
R O E=-2,779228+0,286166 \times \ln \_p l
$$




\subsubsection{Sociedades de crédito imobiliário}

A Tabela 40 apresenta os resultados das regressões para as sociedades de crédito imobiliário. O testes de Breusch e Pagan sugere o modelo de estimação por empilhamento, isto é, Pools. O teste de Schaffer e Stillman também sugere o modelo Pools, pois a variância dos efeitos aleatórios é zero. No entanto, no modelo Pools não existe significância para o patrimônio líquido, e nem para as variáveis relacionadas à alavancagem. Já no modelo de regressão com efeitos fixos existe significância de $1 \%$ para $l n \_p l$.

As regressões foram reprocessadas excluindo-se as variáveis alavanc e alavanc2 e os resultados são apresentados na Tabela 41. Os resultados dos testes de Breusch e Pagan e Schaffer e Stillman indicam a abordagem Pools, mas não existe significância para a variável $l n \_p l$. Desta forma, será adotada a abordagem com efeitos fixos, em que a variável relativa ao porte da instituição tem significância de 5\%. A adoção deste modelo, no entanto, deve ser vista com restrições e se constitui em uma limitação deste trabalho. 
Tabela 40 - Regressões - soc. de crédito imobiliário

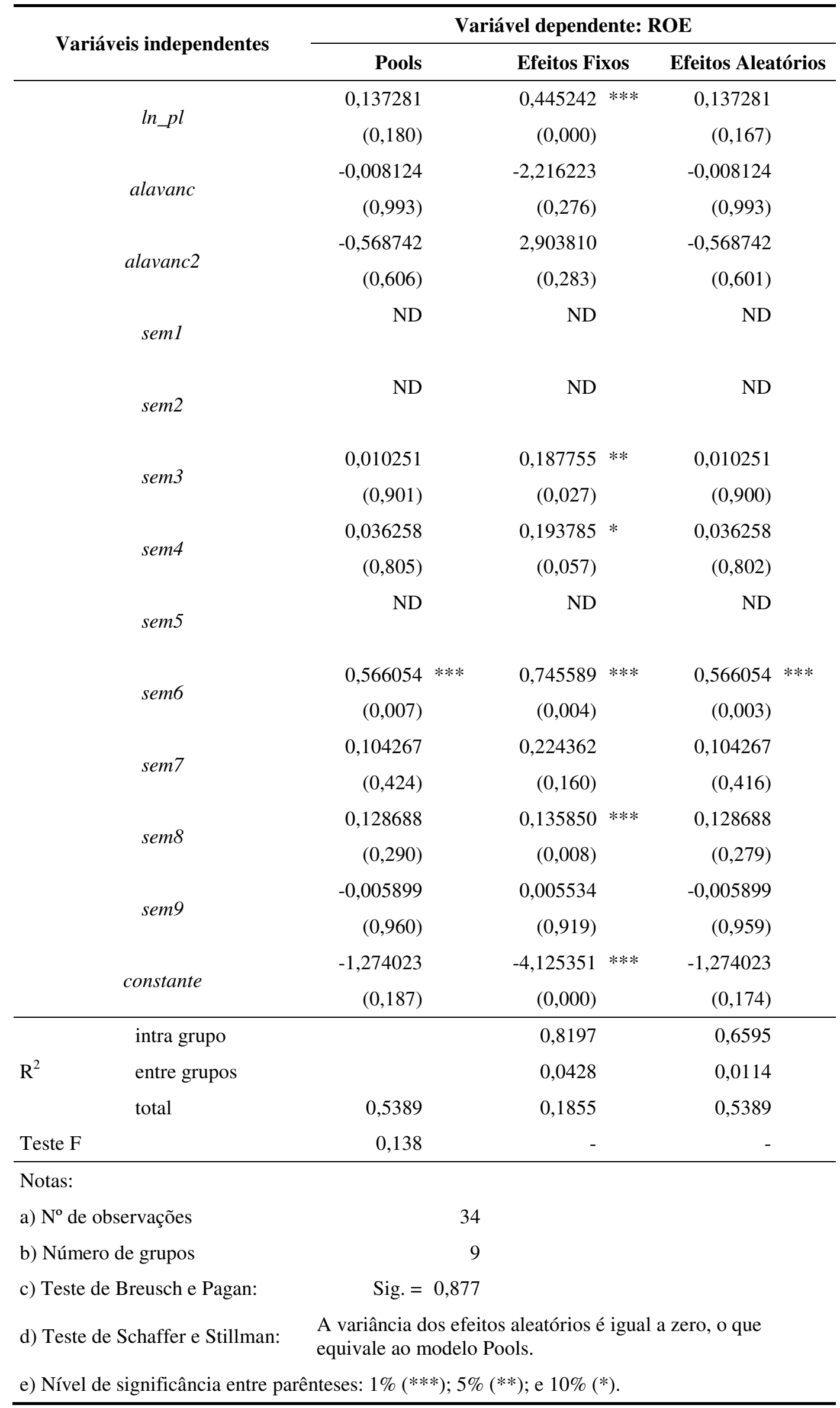


Tabela 41 - Regressões reprocessadas - soc. de crédito imobiliário

\begin{tabular}{|c|c|c|c|c|}
\hline \multirow{2}{*}{\multicolumn{2}{|c|}{ Variáveis independentes }} & \multicolumn{3}{|c|}{ Variável dependente: ROE } \\
\hline & & Pools & Efeitos Fixos & Efeitos Aleatórios \\
\hline \multirow{2}{*}{\multicolumn{2}{|c|}{$l n \_p l$}} & 0,027061 & $0,468545 * *$ & 0,027061 \\
\hline & & $(0,606)$ & $(0,028)$ & $(0,604)$ \\
\hline \multicolumn{2}{|r|}{ seml } & ND & ND & ND \\
\hline \multicolumn{2}{|r|}{$\operatorname{sem} 2$} & ND & ND & ND \\
\hline \multirow{2}{*}{\multicolumn{2}{|c|}{ sem3 }} & 0,184998 & 0,093490 & 0,184998 \\
\hline & & $(0,166)$ & $(0,466)$ & $(0,162)$ \\
\hline \multirow{2}{*}{\multicolumn{2}{|c|}{ sem4 }} & 0,126029 & 0,054472 & 0,126029 \\
\hline & & $(0,281)$ & $(0,652)$ & $(0,278)$ \\
\hline \multirow{2}{*}{\multicolumn{2}{|c|}{ sem5 }} & 0,020896 & $-0,031298$ & 0,020896 \\
\hline & & $(0,875)$ & $(0,807)$ & $(0,874)$ \\
\hline \multirow{2}{*}{\multicolumn{2}{|c|}{ sem6 }} & $0,423091 *$ & 0,363059 & $0,423091 *$ \\
\hline & & $(0,074)$ & $(0,138)$ & $(0,069)$ \\
\hline \multirow{2}{*}{\multicolumn{2}{|c|}{$\operatorname{sem} 7$}} & 0,091881 & 0,043365 & 0,091881 \\
\hline & & $(0,451)$ & $(0,741)$ & $(0,448)$ \\
\hline \multirow{2}{*}{\multicolumn{2}{|c|}{$\operatorname{sem} 8$}} & 0,103068 & 0,004071 & 0,103068 \\
\hline & & $(0,381)$ & $(0,965)$ & $(0,378)$ \\
\hline \multirow{2}{*}{\multicolumn{2}{|c|}{$\operatorname{sem} 9$}} & 0,026079 & $-0,006304$ & 0,026079 \\
\hline & & $(0,829)$ & $(0,932)$ & $(0,828)$ \\
\hline \multirow{2}{*}{\multicolumn{2}{|c|}{ constante }} & $-0,324084$ & $-4,515471 * *$ & $-0,324084$ \\
\hline & & $(0,568)$ & $(0,026)$ & $(0,567)$ \\
\hline \multirow{3}{*}{$\mathrm{R}^{2}$} & intra grupo & & 0,3340 & 0,2129 \\
\hline & entre grupos & & 0,0189 & 0,0471 \\
\hline & total & 0,1906 & 0,0479 & 0,1906 \\
\hline Tes & & 0,199 & 0,033 & - \\
\hline
\end{tabular}

Notas:
a) $\mathrm{N}^{\mathrm{o}}$ de observações
80
b) Número de grupos
13

c) Teste de Breusch e Pagan:

Sig. $=0,978$

d) Teste de Schaffer e Stillman:

Sig. $=\begin{aligned} & \text { A variância dos efeitos aleatórios é igual a zero, } \\ & \text { o que equivale ao modelo Pools. }\end{aligned}$

e) Nível de significância entre parênteses: 1\%(***); 5\%(**); e 10\%(*). 
Na Tabela 42 confirma-se a média condicional zero para o resíduo da regressão com efeitosfixo, cuja normalidade é rejeitada (Tabela 43). O Gráfico 22 traz o histograma dos resíduos.

Tabela 42 - Teste de média condicional zero dos resíduos - soc. de crédito imobiliário

\begin{tabular}{|c|c|c|c|c|c|c|}
\hline \multirow{2}{*}{$\begin{array}{l}\text { Variável } \\
\text { Resíduo }\end{array}$} & \multirow{2}{*}{$\begin{array}{c}\mathbf{N}^{\mathbf{o}} \text { obs. } \\
80\end{array}$} & \multirow{2}{*}{$\begin{array}{c}\text { Média } \\
-1,06 \mathrm{E}-11\end{array}$} & \multirow{2}{*}{$\begin{array}{c}\begin{array}{c}\text { Erro } \\
\text { padrão }\end{array} \\
0,024387\end{array}$} & \multirow{2}{*}{$\begin{array}{c}\begin{array}{c}\text { Desvio } \\
\text { Padrão }\end{array} \\
0,218123\end{array}$} & \multicolumn{2}{|c|}{$\begin{array}{c}\text { Intervalo de } \\
\text { confiança de } 95 \%\end{array}$} \\
\hline & & & & & $-0,048541$ & 0,048541 \\
\hline \multicolumn{2}{|c|}{ Ho: média $($ resíduo $)=0$} & \multicolumn{3}{|c|}{$\mathrm{t}=0$} & \multicolumn{2}{|c|}{$\mathrm{N}^{\mathrm{o}}$ g.1. $=79$} \\
\hline \multicolumn{2}{|c|}{ Ha: média < 0} & \multicolumn{3}{|c|}{ Ha: média $!=0$} & \multicolumn{2}{|c|}{ Ha: média $>0$} \\
\hline \multicolumn{2}{|c|}{$\operatorname{Pr}(\mathrm{T}<\mathrm{t})=0,5000$} & \multicolumn{3}{|c|}{$\operatorname{Pr}(|\mathrm{T}|>|\mathrm{t}|)=1,0000$} & \multicolumn{2}{|c|}{$\operatorname{Pr}(\mathrm{T}>\mathrm{t})=0,5000$} \\
\hline
\end{tabular}

Tabela 43 - Teste de Shapiro-Francia: resíduos - soc. de crédito imobiliário

\begin{tabular}{cccccc}
\hline Variável & $\mathbf{N}^{\mathbf{0}}$ obs. & $\mathbf{W}^{\mathbf{\prime}}$ & $\mathbf{V}^{\prime}$ & $\mathbf{z}$ & Prob>z \\
\hline Resíduo & 80 & 0,8765 & 9,307 & 4,222 & 0,00001 \\
\hline
\end{tabular}

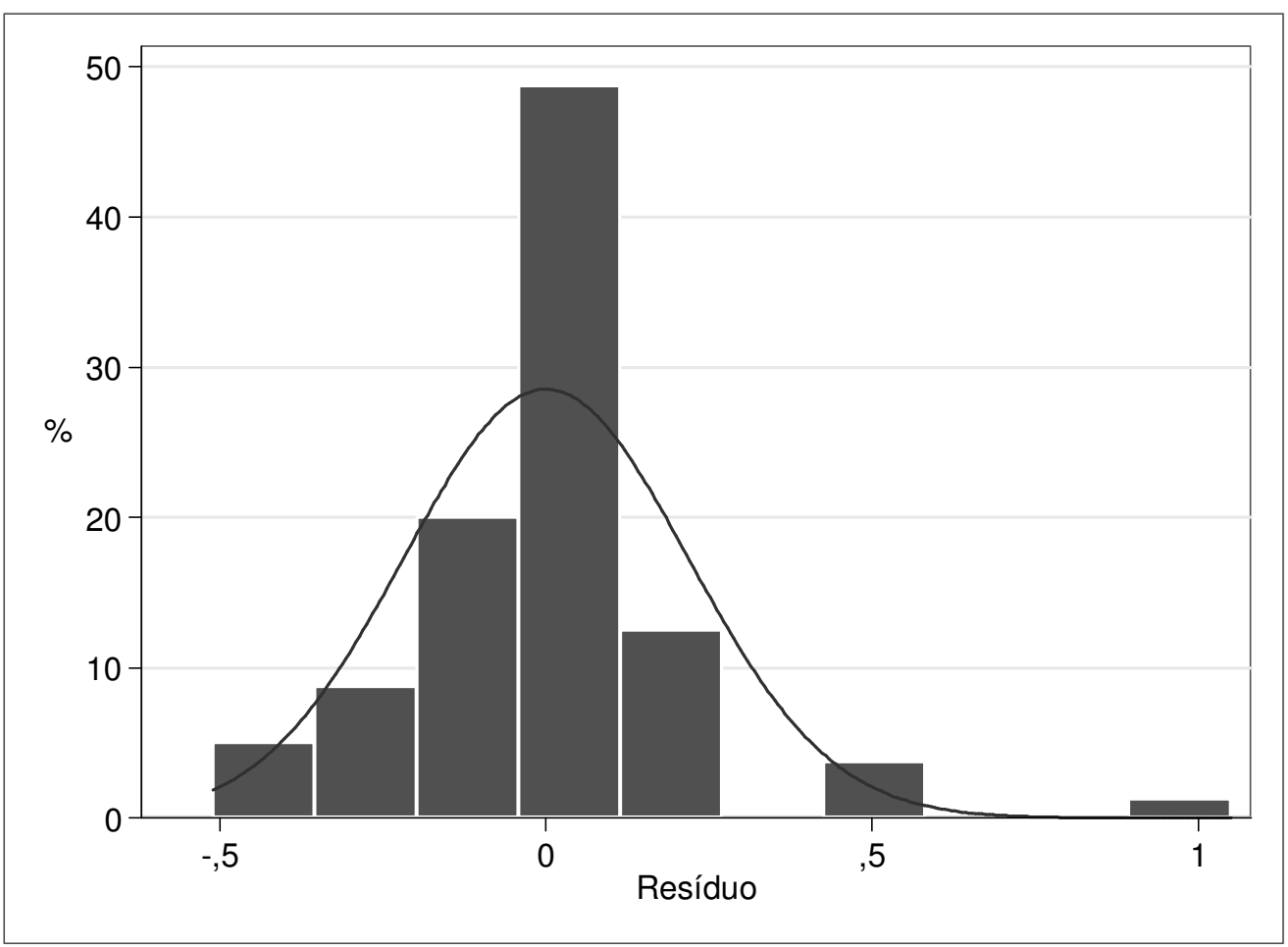

Gráfico 22 - Histograma dos erros - soc. de crédito imobiliário

Para as companhias de crédito imobiliário, o modelo adotado para a correlação entre ROE e PL é dado pela equação (14):

$$
R O E=-4,515471+0,468545 \times \ln \_p l
$$




\subsection{Estimação do custo de capital}

Estudos sobre custo de capital requerem estatísticas de longo prazo. Fama e MacBeth (1973) usaram dados de 1929 a 1968 e Fama e French (1992) de 1962 a 1989. Nos estudos do mercado de capitais brasileiro o pesquisador se depara com algumas dificuldades, pois as séries de preço irão abranger períodos de elevada inflação e eventos exógenos ao mercado de capitais. Como evento exógeno pode-se citar novas leis, planos econômicos e eventos de crédito, como o upgrade ou downgrade da classificação de risco do Brasil. Desta forma, pode não ser razoável projetar parâmetros, como o prêmio de risco, baseado em dados históricos contaminados por situações que não mais caracterizem a realidade econômica do país. Por esta razão, determinados parâmetros apresentam oscilações de tal monta que o seu uso para decisões financeiras é inviável.

Com vistas a isso, as análises realizadas a seguir irão se basear em critérios que apresentem alguma razoabilidade. Como regra geral, os dados do mercado local irão se basear no período pós Plano Real, mais especificamente de janeiro de 1995 em diante.

Concomitantemente com os modelos que se baseiam em dados nacionais e, portanto, podem estar sujeitos a distorções, o custo de capital das instituições financeiras será estimado também por modelo que parte de dados de mercados maduros, como o americano, ao qual se incorpora o rico Brasil. Ao se estimar o custo de capital por mais de um modelo espera-se obter uma convergência para aquele que deve ser a taxa de interesse do investidor.

\subsubsection{Estimação da taxa livre de risco}

Para definir a taxa livre de risco brasileira, partiu-se de uma série de taxas de negociação de Letras do Tesouro Nacional (LTNs), obtidas no sítio do Tesouro Direto. As informações disponíveis trazem a data de negociação, o vencimento do título, e as taxas de compra e de venda. Como são diversos vencimentos, é possível interpolá-los para estimar a taxa de juros para um, dois e três anos, tal qual uma estrutura a termo de taxas de juros. Esse procedimento foi realizado para cada data de negociação, e as taxas obtidas são apresentadas no Gráfico 23. As taxas refletem a média entre a de compra e a de venda. A análise foi restrita ao período de 2010 a 2014, que coincide com o período dos balanços analisados. 


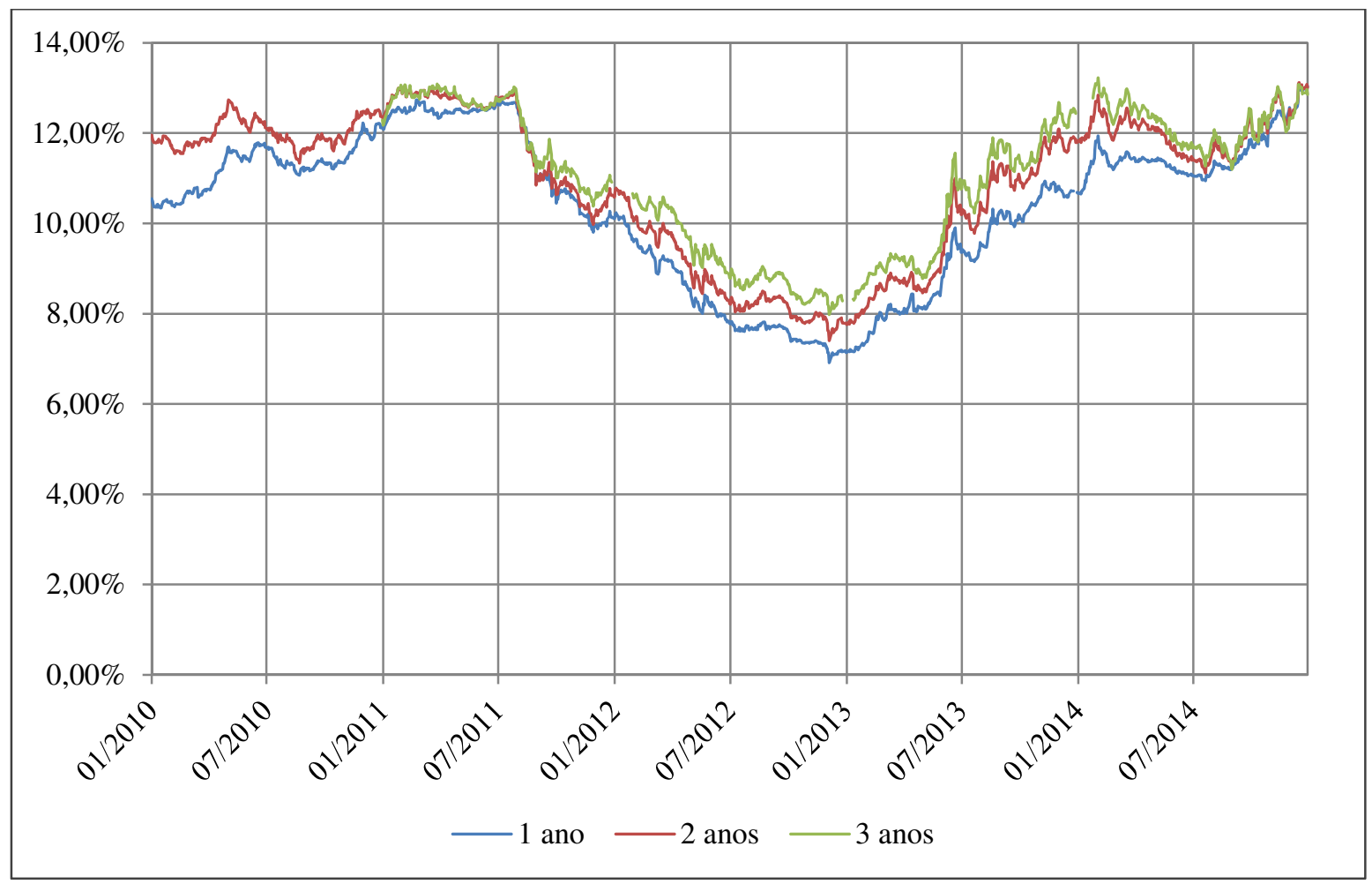

Gráfico 23 - Estrutura a termo de taxas de LTNs

Fonte: Tesouro Direto

As médias anuais destas taxas são apresentadas na Tabela 44. Nesta tabela foi incorporada uma coluna relativa à taxa SELIC acumulada no ano, para fins de comparação.

Tabela 44 - Taxas médias anuais - LTNs

\begin{tabular}{ccccc}
\hline \multirow{2}{*}{ Ano } & Taxa Selic & \multicolumn{3}{c}{ Prazo } \\
\cline { 3 - 5 } & (acumulado no ano) & $\mathbf{1}$ ano & $\mathbf{2}$ anos & $\mathbf{3}$ anos \\
\hline 2010 & $9,77 \%$ & $11,25 \%$ & $12,00 \%$ & - \\
2011 & $11,62 \%$ & $11,79 \%$ & $12,00 \%$ & $12,14 \%$ \\
2012 & $8,51 \%$ & $8,25 \%$ & $8,79 \%$ & $9,16 \%$ \\
2013 & $8,21 \%$ & $9,15 \%$ & $9,93 \%$ & $10,46 \%$ \\
2014 & $10,90 \%$ & $11,55 \%$ & $12,03 \%$ & $12,22 \%$ \\
\hline Média Geral & $9,79 \%$ & $10,40 \%$ & $10,96 \%$ & $11,03 \%$ \\
\hline
\end{tabular}

Notou-se dados faltantes em alguns trechos da série de 3 anos; desta forma, preferiu-se adotar o vértice de 2 anos como referência para a taxa livre de risco. Desta forma, o valor considerado no cálculo do custo de capital corresponde a 10,96\% a.a.

A taxa livre de risco americana foi obtida a partir da estrutura a termo das taxas de $U S$ Treasuries (Gráfico 24), disponível no sítio do United States Department of The Treasury. 


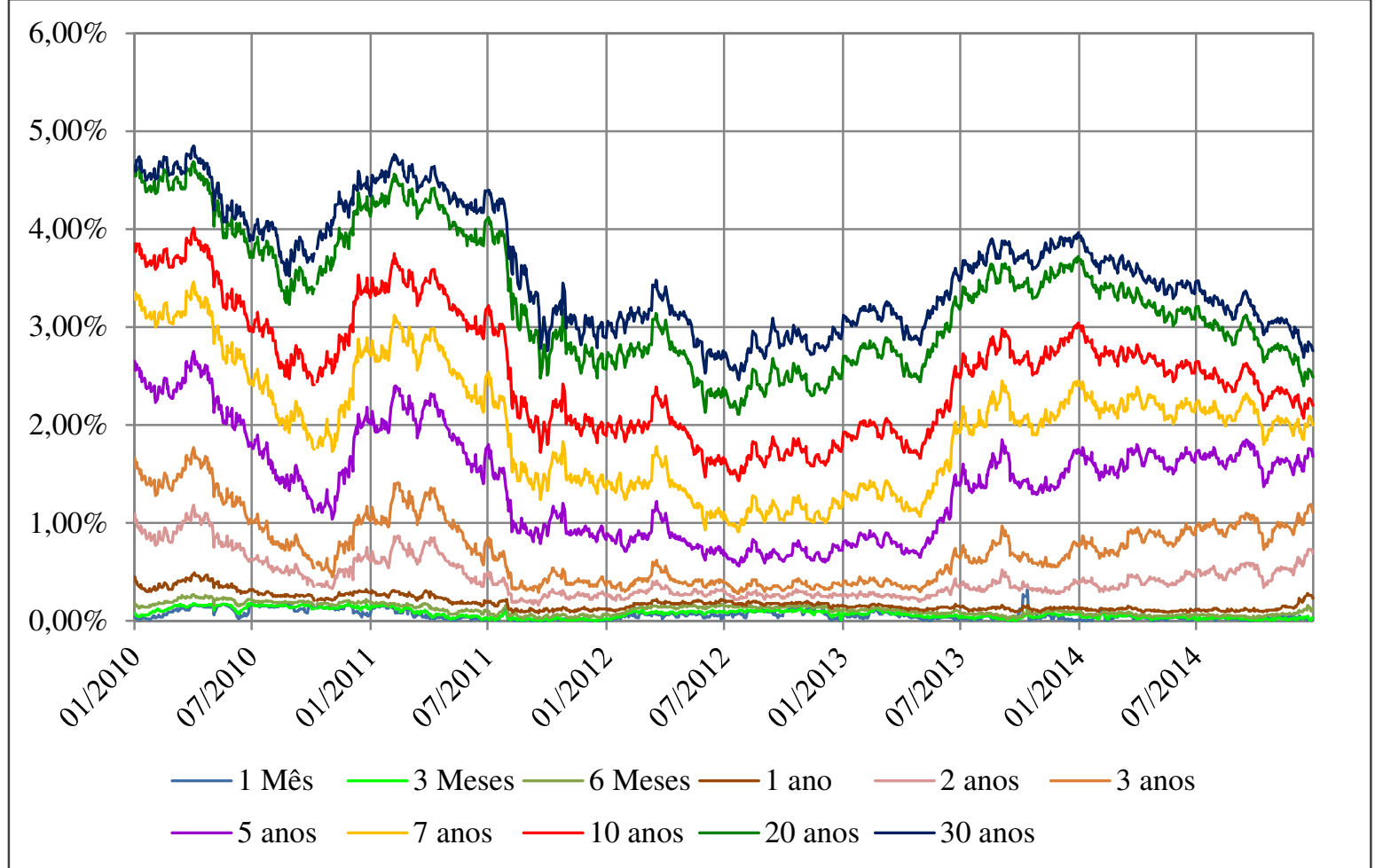

Gráfico 24 - Estrutura a termo de taxas de títulos do Tesouro Americano

Fonte: United States Department of The Treasury

A Tabela 45 apresenta a média destas taxas para cada ano.

Tabela 45 - Taxas médias anuais dos títulos do Tesouro Americano

\begin{tabular}{|c|c|c|c|c|c|c|c|c|c|c|c|}
\hline \multirow[b]{2}{*}{ Ano } & \multicolumn{11}{|c|}{ Prazo } \\
\hline & $\begin{array}{c}1 \\
\text { mês }\end{array}$ & $\begin{array}{c}3 \\
\text { meses }\end{array}$ & $\begin{array}{c}6 \\
\text { meses }\end{array}$ & $\begin{array}{c}1 \\
\text { ano }\end{array}$ & $\begin{array}{c}2 \\
\text { anos }\end{array}$ & $\begin{array}{c}3 \\
\text { anos }\end{array}$ & $\begin{array}{c}5 \\
\text { anos }\end{array}$ & $\begin{array}{c}7 \\
\text { anos }\end{array}$ & $\begin{array}{c}10 \\
\text { anos }\end{array}$ & $\begin{array}{c}20 \\
\text { anos }\end{array}$ & $\begin{array}{c}30 \\
\text { anos }\end{array}$ \\
\hline 2010 & $0,11 \%$ & $0,14 \%$ & $0,20 \%$ & $0,32 \%$ & $0,70 \%$ & $1,11 \%$ & $1,93 \%$ & $2,62 \%$ & $3,22 \%$ & $4,03 \%$ & $4,25 \%$ \\
\hline 2011 & $0,04 \%$ & $0,05 \%$ & $0,10 \%$ & $0,18 \%$ & $0,45 \%$ & $0,75 \%$ & $1,52 \%$ & $2,16 \%$ & $2,78 \%$ & $3,62 \%$ & $3,91 \%$ \\
\hline 2012 & $0,07 \%$ & $0,09 \%$ & $0,13 \%$ & $0,17 \%$ & $0,28 \%$ & $0,38 \%$ & $0,76 \%$ & $1,22 \%$ & $1,80 \%$ & $2,54 \%$ & $2,92 \%$ \\
\hline 2013 & $0,05 \%$ & $0,06 \%$ & $0,09 \%$ & $0,13 \%$ & $0,31 \%$ & $0,54 \%$ & $1,17 \%$ & $1,74 \%$ & $2,35 \%$ & $3,12 \%$ & $3,45 \%$ \\
\hline 2014 & $0,03 \%$ & $0,03 \%$ & $0,06 \%$ & $0,12 \%$ & $0,46 \%$ & $0,90 \%$ & $1,64 \%$ & $2,14 \%$ & $2,54 \%$ & $3,07 \%$ & $3,34 \%$ \\
\hline $\begin{array}{l}\text { Média } \\
\text { Geral }\end{array}$ & $0,06 \%$ & $0,07 \%$ & $0,12 \%$ & $0,19 \%$ & $0,44 \%$ & $0,74 \%$ & $1,41 \%$ & $1,98 \%$ & $2,54 \%$ & $3,28 \%$ & $3,57 \%$ \\
\hline
\end{tabular}

Fonte: United States Department of The Treasury

Adotou-se o prazo de 10 anos como referência para a taxa livre de risco americana. Desta forma, como taxa livre de risco para o mercado americano, considerou-se 2,54\% a.a. 


\subsubsection{Estimação do prêmio de risco de mercado}

O conceito do prêmio de risco de mercado é fundamental na moderna teoria de finanças e representa o alicerce para a maioria dos modelos de previsão de longo prazo sobre o retornos dos investimentos (GOETZMANN, IBBOTSON; 2005). Dada sua importância, Damodaran (2009) considera surpreendente como pouca atenção tem sido dispendida para sua estimação. $\mathrm{O}$ autor procurou desmistificar alguns pontos sobre o assunto, dentre os quais o de que o prêmio de risco de mercado não é constante, pois reflete os fundamentos econômicos e a aversão de risco do investidor que se alteram ao longo do tempo.

Pode-se dizer que o prêmio de risco do mercado brasileiro é cercado de incertezas. Fernandez et al (2014) realizou pesquisa acerca do ERP em 88 países, com 8.228 respostas, na qual a disparidade das respostas relativas ao Brasil, medida pelo desvio padrão, é superada apenas pela do Paquistão, Grécia, Venezuela e Equador. Estes países apresentam ERP entre 11\% e $15 \%$, contra $7,8 \%$ do Brasil.

Ainda segundo Fernandez (2006) e Fernandez et al (2010, 2011, 2013a, 2013b), o prêmio de risco de mercado (ERP) pode ser obtido de quatro formas:

- Utilizando-se dados históricos do retorno do mercado de capitais e da taxa livre de risco, no que o autor convencionou chamar por HEP - Historical Equity Premium;

- Baseado na expectativa de mercado, ou EEP - Expected Equity Premium, que consiste em uma pesquisa junto a pesquisadores e investidores.

- Baseado em pesquisas junto a investidores e pesquisadores sobre o prêmio de risco requerido, ou REP - Required Equity Premium, isto é, qual deve ser o retorno incremental sobre uma carteira diversificada, com relação ao ativo livre de risco;

- Com base no prêmio implícito, ou IEP - Implied Equity Premium, que parte do preço da ação $\left(\mathrm{P}_{0}\right)$, do dividendo esperado por ação para o período subsequente $\left(\mathrm{d}_{1}\right)$, da taxa livre de risco $\left(\mathrm{R}_{\mathrm{F}}\right)$ e da taxa e crescimento $(\mathrm{g})$.

Como:

$$
P_{0}=\frac{d_{1}}{K_{e}-g}
$$


Faz-se:

$$
I E P=\frac{d_{1}}{P_{0}}+g-R_{F}
$$

Fernandez et al (2010, 2011, 2013a, 2013b, 2013c, 2014) pesquisou junto a acadêmicos, especialistas e corporações o prêmio de risco de mercado requerido (REP) em diversos países; os resultados para o mercado americano e brasileiro são apresentados na Tabela 46.

Tabela 46 - Prêmio de risco de mercado segundo Fernandez

\begin{tabular}{ccc}
\hline Ano pesquisado & Estados Unidos & Brasil \\
\hline 2010 & $6,0 \%$ & $6,8 \%$ \\
2011 & $5,5 \%$ & $7,7 \%$ \\
2012 & $5,5 \%$ & $7,9 \%$ \\
2013 & $5,7 \%$ & $6,5 \%$ \\
2014 & $5,4 \%$ & $7,8 \%$ \\
Média & $5,62 \%$ & $7,34 \%$ \\
\hline
\end{tabular}

Fonte: Fernandez et al (2010, 2011, 2013a, 2013b, 2014)

Da mesma forma, Aswhat Damodaran divulga no sítio da New York University Stern School of Business os valores de ERP para o mercado americano e para outros países. Damodaran (2009, p. 332) estima o prêmio de mercados não maduros, como o brasileiro, a partir do prêmio de risco do mercado americano, a que considera um mercado maduro, multiplicando este último por um fator de ajuste denominado Relative Equity Market Standard Deviations, que nada mais é do que a relação entre a volatilidade do mercado local e a volatilidade do mercado maduro, como apresentado na equação (17):

$$
E\left(r_{m}^{i}\right)=E\left(r_{m}^{G L}\right) \times \frac{\sigma_{i}}{\sigma_{G L}}
$$

\footnotetext{
Em que:

$E\left(r_{m}^{i}\right)$ é a esperança de retorno do mercado i,

$E\left(r_{m}^{G L}\right)$ é a esperança de retorno do mercado global, ou mercado maduro,

$\sigma_{i}$ é a volatilidade do mercado i, e

$\sigma_{G L}$ é a volatilidade do mercado global ou maduro.
}

Em seu sítio, Damodaran utiliza-se de um fator de ajuste ao prêmio de risco americano de 1,5. Assim, se $\mathrm{ERP}_{\mathrm{EUA}}=5,75$, o autor obtém $\mathrm{ERP}_{\mathrm{BR}}=8,60$. Com o intuito de verificar se este fator é adequado, regrediu-se a volatilidade mensal do IBOVESPA pela volatilidade mensal do 
S\&P500 nos últimos 20 anos, forçando o intercepto igual a zero. Os resultados, apresentados na Tabela 47, corroboram com o valor utilizado.

Tabela 47 - Regressão: $\sigma_{\text {IBOVESPA }} \times \sigma_{\text {S\&P500 }}$

\begin{tabular}{|c|c|}
\hline \multicolumn{2}{|c|}{ Variável dependente: $\sigma_{\text {IBOVESPA }}$} \\
\hline Variável independente & Coef. \\
\hline$\sigma_{\mathrm{S} \& \mathrm{P} 500}$ & $\begin{array}{c}1,561180 * * * \\
(0,000)\end{array}$ \\
\hline constante & - \\
\hline $\mathrm{R}^{2}$ & 0,7545 \\
\hline Teste F & 0,0000 \\
\hline
\end{tabular}

Notas:

a) $\mathrm{N}^{\mathrm{o}}$ de observações $=240$

b) Nível de significância: $1 \%(* * *) ; 5 \%(* *)$; e $10 \%(*)$.

Valores entre parênteses.

Os resultados para ERP divulgados no sítio da New York University Stern School of Business são apresentados na Tabela 48.

Tabela 48 - Prêmio de risco de mercado segundo Damodaran

\begin{tabular}{ccc}
\hline Ano & Estados Unidos & Brasil \\
\hline 2010 & 5,0 & 8,0 \\
2011 & 6,0 & 8,6 \\
2012 & 5,8 & 8,4 \\
2013 & 5,0 & 7,9 \\
2014 & 5,8 & 8,6 \\
\hline Média & 5,51 & 8,30 \\
\hline
\end{tabular}

Fonte: Damodaran

O prêmio de risco a ser utilizado neste trabalho irá se basear nos valores recomendados por ambos os autores.

Uma vez que se pretende comparar o ROE das instituições financeiras com seu custo de capital, é razoável que se utilize o ERP médio ao longo do período em que os demonstrativos financeiros foram gerados, isto é, entre 2010 e 2014. 


\subsubsection{Estimação do beta dos bancos brasileiros}

Com o objetivo de estimar o beta das instituições financeiras brasileiras, obteve-se uma base de dados junto à ECONOMÁTICA do preço de fechamento das ações ordinárias de instituições financeiras transacionadas na BOVESPA. Os dados abrangem o período de 10 anos, de janeiro de 2005 a dezembro de 2014. Foram encontradas 23 ações naquele serviço de informações, algumas até mesmo sem cotações. De forma geral, o número de séries de preço que apresentam dados suficientes e contínuos para o cálculo do beta é pequeno.

As ações utilizadas, bem como o número de cotações de fechamento obtidas no período analisado, são apresentadas na Tabela 49.

Tabela 49 - Número de cotações entre 2005 a 2014

\begin{tabular}{lclc}
\hline Ativo & $\mathbf{N}^{\mathbf{0}}$ de cotações & Ativo & $\mathbf{N}^{\mathbf{0}}$ de cotações \\
\hline IBOVESPA & 2473 & BANRISUL ON & 873 \\
BRADESCO ON & 2473 & BICBANCO ON & 516 \\
BRASIL ON & 2473 & BRB ON & 153 \\
ITAU UNIBANCO ON & 2381 & BANESE ON & 143 \\
BANESTES ON & 2222 & ESTADO CEARÁ ON & 55 \\
AMAZONIA ON & 2204 & INDUSVAL ON & 22 \\
SANTANDER ON & 1658 & ABC BRASIL ON & 1 \\
ALFA INV ON & 1489 & DAYCOVAL ON & 1 \\
MERCANTIL BRASIL ON & 902 & SOFISA ON & 1 \\
\hline
\end{tabular}

Fonte: Economática

Com exceção de pouquíssimos bancos de investimento, todas as demais cotações disponíveis referem-se a bancos comerciais ou múltiplos com carteira comercial. Desta forma, não será possível distinguir o beta entre diferentes tipologias, o que fará com que se adote uma única curva para o custo de capital para todas as modalidades de instituição.

Tendo em vista a dificuldade em se trabalhar com retornos diários com séries repletas de falhas, preferiu-se calcular a média mensal das cotações de fechamento de cada ativo. $\mathrm{O}$ mesmo tratamento também foi dispensado para o IBOVESPA, por uma questão de coerência. A esses dados, foi agregado o Patrimônio Líquido obtido junto ao BACEN, corrigido pelo IPCA. A estrutura do arquivo gerado continha os seguintes campos: instituição, data, retorno mensal da ação, retorno mensal do IBOVESPA e patrimônio líquido. 
A Tabela 50 apresenta o número de retornos mensais obtidos, que serão utilizados para o cálculo do beta do setor. O valor médio mensal das ações e o retorno mensal estão disponíveis nos anexos 2 e 3 , respectivamente.

Tabela 50 - Retorno mensais entre 2005 e 2014

\begin{tabular}{lclc}
\hline Ativo & $\begin{array}{c}\mathbf{N}^{\mathbf{0}} \text { de retornos } \\
\text { mensais }\end{array}$ & Ativo & $\begin{array}{c}\mathbf{N}^{\mathbf{0}} \text { de retornos } \\
\text { mensais }\end{array}$ \\
\hline ALFA INV ON & 120 & BRASIL ON & 120 \\
AMAZONIA ON & 120 & BRB ON & 40 \\
BANESE ON & 41 & ESTADO CEARÁ ON & 12 \\
BANESTES ON & 120 & INDUSVAL ON & 5 \\
BANRISUL ON & 116 & ITAU UNIBANCO ON & 120 \\
BICBANCO ON & 68 & MERCANTIL BRASIL ON & 98 \\
BRADESCO ON & 120 & SANTANDER ON & 92 \\
\hline
\end{tabular}

A Tabela 51 apresenta a regressão para a estimação do beta das instituições financeiras. $\mathrm{O}$ modelo adotado foi o de painel com efeitos fixos, com erro padrão robusto. No item 4.9.2, justificou-se o uso da abordagem com efeitos fixos. A variável independente considerada foi o retorno mensal do ativo e as variáveis explicativas são o retorno mensal do IBOVESPA ( $\left.\xi_{I B O V E S P A}\right)$ e o patrimônio líquido, na forma logarítmica $\left(l n \_p l\right)$; na hipótese de existir correlação negativa com significância para esta última será possível considerar o size effect.

Tabela 51 - Regressão para estimação do beta dos bancos

\begin{tabular}{|c|c|c|}
\hline \multicolumn{3}{|c|}{ Variável dependente: $\xi$ ação } \\
\hline \multicolumn{2}{|c|}{ Variáveis independentes } & Coef. \\
\hline \multirow{2}{*}{\multicolumn{2}{|c|}{$\xi_{I B O V E S P A}$}} & $0,760947 * * *$ \\
\hline & & $(0,000)$ \\
\hline \multirow{2}{*}{\multicolumn{2}{|c|}{$\ln \_p l$}} & $-0,010717$ \\
\hline & & $(0,133)$ \\
\hline \multirow{2}{*}{\multicolumn{2}{|c|}{ constante }} & 0,174341 \\
\hline & & $(0,118)$ \\
\hline & intra grupo & 0,2306 \\
\hline & entre grupos & 0,2516 \\
\hline & geral & 0,1971 \\
\hline \multicolumn{2}{|c|}{ Teste F } & 0,0000 \\
\hline
\end{tabular}

Notas:

a) $\mathrm{N}^{\mathrm{o}}$ de observações $=1.192 ; \mathrm{n}^{\circ}$ de grupos $=14$.

b) Nível de significância entre parênteses: $1 \%(* * *) ; 5 \%(* *) ;$ e $10 \%(*)$. 
Da Tabela 51, observa-se que o retorno do IBOVESPA é positivo e significante. O patrimônio líquido apresenta coeficiente negativo, dentro da lógica de teoria de finanças, mas carece de significância. Desta forma, com base nos dados obtidos, não se pode considerar a existência do efeito tamanho para as ações analisadas. Certamente, se fosse maior a frequência das transações na IBOVESPA com as ações dos bancos menores, o estudo do size effect seria beneficiado.

Excluindo-se o logaritmo do patrimônio líquido da regressão, obtém-se um beta igual a 0,767424, tal como apresentado na Tabela 52.

Tabela 52 - Regressão reprocessada para estimação do beta

\begin{tabular}{|c|c|c|}
\hline \multicolumn{3}{|c|}{ Variável dependente: $\xi$ ação } \\
\hline Vari & independentes & Coef. \\
\hline \multicolumn{2}{|c|}{$\xi_{I B O V E S P A}$} & $\begin{array}{c}0,767424 * * * \\
(0,000)\end{array}$ \\
\hline \multicolumn{2}{|c|}{ constante } & $\begin{array}{r}0,007704 \\
(0,002)\end{array}$ \\
\hline \multirow{3}{*}{$\mathrm{R}^{2}$} & intra grupo & 0,2293 \\
\hline & entre grupos & 0,3521 \\
\hline & geral & 0,2292 \\
\hline \multicolumn{2}{|c|}{ Teste F } & 0,0000 \\
\hline
\end{tabular}
Notas:

a) $\mathrm{N}^{\mathrm{o}}$ de observações $=1.192 ; \mathrm{n}^{\circ}$ de grupos $=14$.

b) Nível de significância entre parênteses: $1 \%(* * *) ; 5 \%(* *)$; e $10 \%(*)$.

Damodaran indica um beta alavancado de 0,53 para bancos regionais nos EUA, e 0,81 para bancos denominados Money Center. Portanto, o valor calculado pela regressão é coerente.

Na Tabela 53 confirma-se que a média dos resíduos é estatisticamente igual a zero.

Tabela 53 - Teste de média condiciona zero dos resíduos - beta dos bancos brasileiros

\begin{tabular}{|c|c|c|c|c|c|c|}
\hline \multirow{2}{*}{$\begin{array}{l}\text { Variável } \\
\text { Resíduo }\end{array}$} & \multirow{2}{*}{$\begin{array}{c}\mathbf{N}^{\mathbf{o}} \text { obs. } \\
1192 \\
\end{array}$} & \multirow{2}{*}{$\begin{array}{c}\text { Média } \\
-1,71 \mathrm{e}-11\end{array}$} & \multirow{2}{*}{$\begin{array}{c}\begin{array}{c}\text { Erro } \\
\text { padrão }\end{array} \\
0,002433 \\
\end{array}$} & \multirow{2}{*}{$\begin{array}{c}\begin{array}{c}\text { Desvio } \\
\text { Padrão }\end{array} \\
0,084004 \\
\end{array}$} & \multicolumn{2}{|c|}{$\begin{array}{c}\text { Intervalo de } \\
\text { confiança de } 95 \%\end{array}$} \\
\hline & & & & & -0004774 & 0,004774 \\
\hline \multicolumn{2}{|c|}{ Ho: média $($ resíduo $)=0$} & \multicolumn{3}{|c|}{$\mathrm{t}=0$} & \multicolumn{2}{|c|}{$\mathrm{N}^{\mathrm{o}}$ g.l. $=1191$} \\
\hline \multicolumn{2}{|c|}{ Ha: média < 0} & \multicolumn{3}{|c|}{ Ha: média $!=0$} & \multicolumn{2}{|c|}{ Ha: média > 0} \\
\hline \multicolumn{2}{|c|}{$\operatorname{Pr}(\mathrm{T}<\mathrm{t})=0,5000$} & \multicolumn{3}{|c|}{$\operatorname{Pr}(|\mathrm{T}|>|\mathrm{t}|)=1,0000$} & \multicolumn{2}{|c|}{$\operatorname{Pr}(T>t)=0,5000$} \\
\hline
\end{tabular}


O Gráfico 25 apresenta o histograma dos resíduos, e a Tabela 54 apresenta o teste de ShapiroFrancia, que rejeitou a normalidade dos mesmos.

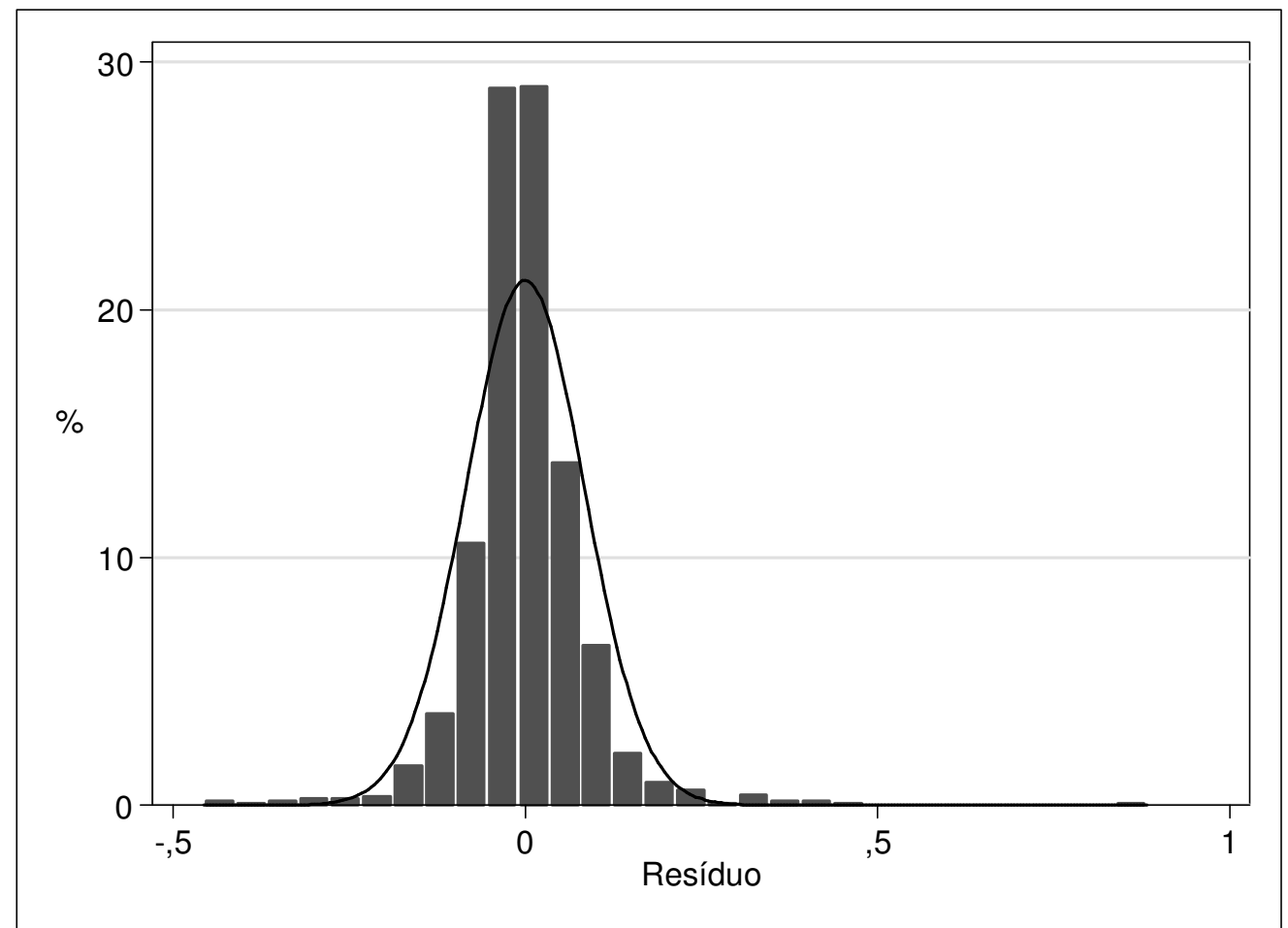

Gráfico 25 - Histograma de frequência dos resíduos - beta dos bancos brasileiros

Tabela 54 - Teste de normalidade dos resíduos - beta dos bancos brasileiros

\begin{tabular}{cccccc}
\hline Variável & $\mathbf{N}^{\mathbf{0}}$ obs. & $\mathbf{W}^{\prime}$ & $\mathbf{V}^{\prime}$ & $\mathbf{z}$ & Prob $>\mathbf{z}$ \\
\hline Resíduo & 1192 & 0,8664 & 102,92 & 8,721 & 0,00001 \\
\hline
\end{tabular}

Do exposto, será adotado um beta fixo de 0,767424, independente do porte ou da tipologia da instituição.

\subsubsection{Estimação do beta do IBOVESPA com relação ao S\&P500}

O beta do IBOVESPA, relativamente ao S\&P500, consiste em um dos parâmetros utilizados pelo IAPM. O período analisado foi limitado a 20 anos, de 1995 a 2014, evitando assim o período anterior ao Plano Real. Na Tabela 55 são apresentados os resultados da regressão simples entre os retornos mensais do IBOVESPA ( $\xi_{\text {IвоVESPA }}$ ) e o retorno do S\&P500

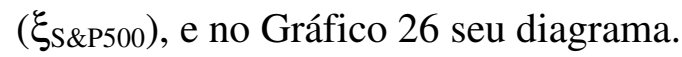


Tabela 55 - Regressão para estimação do beta do IBOVESPA

Variável dependente: $\xi_{\text {IBOvESPA }}$

\begin{tabular}{cc}
\hline Variáveis independentes & Coef. \\
$\xi_{\text {S\&P500 }}$ & $1,232430 * * *$ \\
& $(0,000)$ \\
Constante & 0,002464 \\
$\mathrm{R}^{2}$ & $(0,607)$ \\
\hline Teste F & 0,3664 \\
\hline
\end{tabular}

Notas:

a) $\mathrm{N}^{\mathrm{o}}$ de observações $=240$

b) Nível de significância: $1 \%(* * *) ; 5 \%(* *)$; e $10 \%(*)$. Valores entre parênteses.

c) Teste de Breusch-Pagan / Cook-Weisberg:

Ho: As variâncias são constantes. $\quad$ Prob $>\chi 2=0,0079$

d) Teste RESET de Ramsey:

Ho: modelo não tem variável omitida. Prob $>\mathrm{F}=0,8321$

Pode-se notar que o retorno do S\&P500 é positivo e significante ao nível de $1 \%$. O teste de Ramsey aceita a hipótese de que não existe variável omitida; no entanto, o teste Breush Pagan / Cook-Weisberg rejeita a hemocedasticidade. Por esta razão, a regressão foi reprocessada utilizando-se o erro padrão robusto, e como resultado o retorno do S\&P500 manteve significância de $1 \%$.

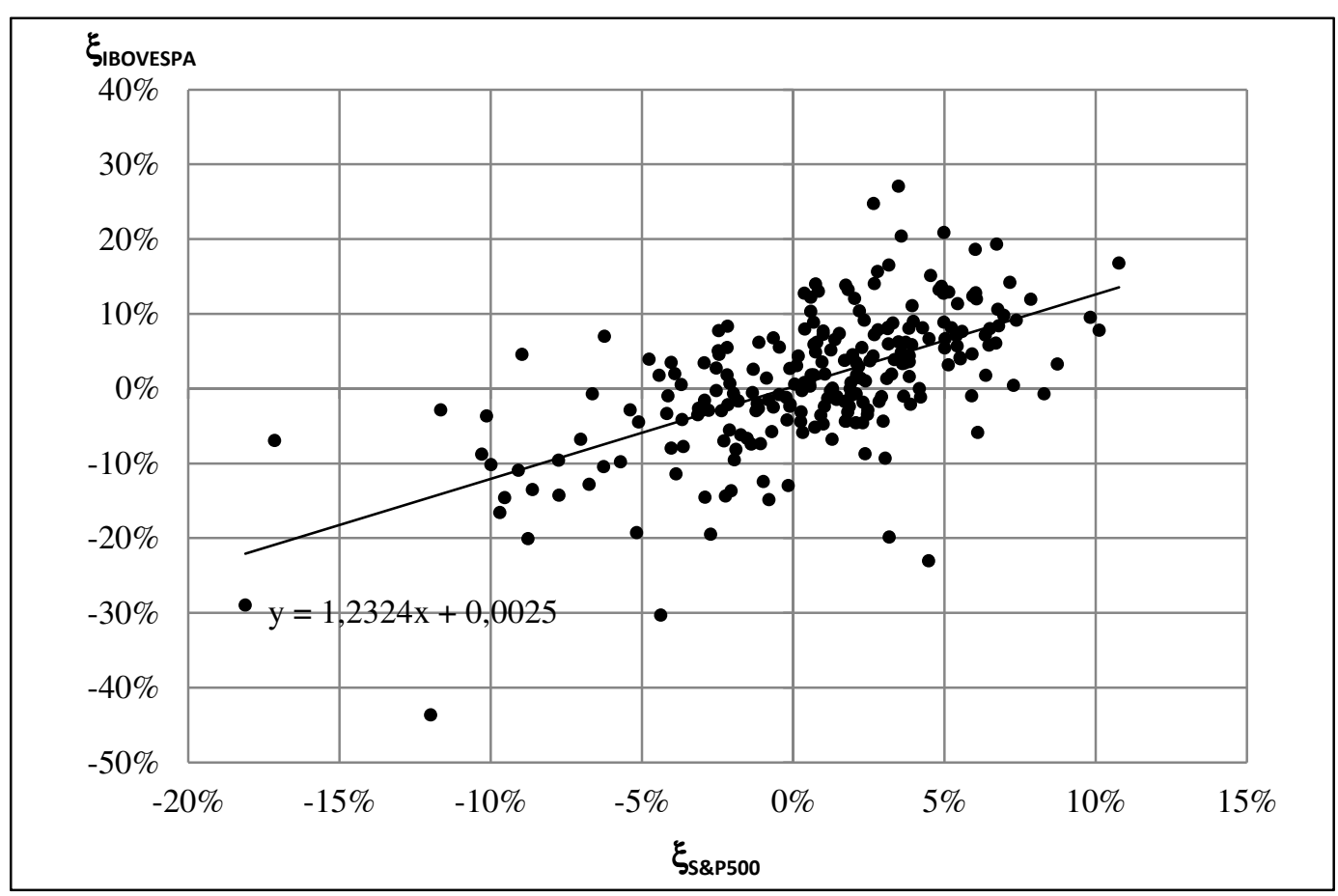

Gráfico 26 - Retorno do IBOVESPA x Retorno do S\&P500 
A Tabela 56 mostra que a média dos resíduos da regressão entre os índices Ibovespa e S\&P500 é estatisticamente igual a zero.

Tabela 56 - Teste de média condiciona zero dos resíduos - beta Ibovespa / S\&P500

\begin{tabular}{|c|c|c|c|c|c|c|}
\hline \multirow{2}{*}{$\begin{array}{l}\text { Variável } \\
\text { Resíduo }\end{array}$} & \multirow{2}{*}{$\begin{array}{c}\mathbf{N}^{\mathbf{o}} \mathbf{o b s} . \\
240\end{array}$} & \multirow{2}{*}{$\begin{array}{c}\text { Média } \\
2,12 \mathrm{E}-10\end{array}$} & \multirow{2}{*}{$\begin{array}{c}\begin{array}{c}\text { Erro } \\
\text { padrão }\end{array} \\
0,004731\end{array}$} & \multirow{2}{*}{$\begin{array}{c}\begin{array}{c}\text { Desvio } \\
\text { Padrão }\end{array} \\
0,073298\end{array}$} & \multicolumn{2}{|c|}{$\begin{array}{c}\text { Intervalo de } \\
\text { confiança de } 95 \%\end{array}$} \\
\hline & & & & & $-0,00932$ & 0,009321 \\
\hline \multicolumn{2}{|c|}{ Ho: média (resíduo) =0 } & \multicolumn{3}{|c|}{$t=0$} & \multicolumn{2}{|c|}{$\mathrm{N}^{\mathrm{o}}$ g.1. = 239} \\
\hline \multicolumn{2}{|c|}{ Ha: média < 0} & \multicolumn{3}{|c|}{ Ha: média $!=0$} & \multicolumn{2}{|c|}{ Ha: média > 0} \\
\hline \multicolumn{2}{|c|}{$\operatorname{Pr}(\mathrm{T}<\mathrm{t})=0,5000$} & \multicolumn{3}{|c|}{$\operatorname{Pr}(|\mathrm{T}|>|\mathrm{t}|)=1,0000$} & \multicolumn{2}{|c|}{$\operatorname{Pr}(\mathrm{T}>\mathrm{t})=0,5000$} \\
\hline
\end{tabular}

Na Tabela 57 é apresentado o teste de Shapiro-Francia para os resíduos, que rejeitou a hipótese a normalidade dos mesmos.

Tabela 57 - Teste de normalidade dos resíduos - beta Ibovespa / S\&P500

\begin{tabular}{cccccc}
\hline Variável & $\mathbf{N}^{\mathbf{o}}$ obs. & $\mathbf{W}^{\prime}$ & $\mathbf{V}^{\prime}$ & $\mathbf{z}$ & Prob $>\mathbf{z}$ \\
\hline Resíduo & 240 & 0,96181 & 7,18 & 4,096 & 0,00002 \\
\hline
\end{tabular}

Com base nos resultados, será adotado beta IBOVESPA / S\&P500 igual a 1,2324.

\subsubsection{Cálculo do custo de capital}

Para maior consistência do parâmetro utilizado como custo de capital próprio, decidiu-se calculá-lo por dois modelos diferentes, o CAPM de Sharpe e o IAPM de Solnik. Como prêmio de risco de mercado serão considerados os parâmetros de dois pesquisadores, Fernandez e Damodaran. Desta forma, foram concebidos quatro modelos para a estimação de $\mathrm{K}_{\mathrm{E}}$ :

a) O Modelo 1, baseado no CAPM convencional, utilizando como prêmio de risco a média das pesquisas realizadas por Fernandez et al (2010, 2011, 2013a, 2013b, 2013c, 2014) para o mercado brasileiro, entre 2010 e 2014.

b) O Modelo 2, baseado no CAPM convencional, utilizando como prêmio de risco a média de Damodaran para o mercado brasileiro, em igual período.

c) O Modelo 3, baseado no IAPM, em que o beta utilizado corresponde ao produto entre 
o beta dos retornos de ativos brasileiros regredidos pelos retornos do IBOVESPA, e o beta dos retornos do IBOVESPA regredido pelos retornos do S\&P500. Como prêmio de risco adotou-se a média do valor de ERP nos EUA de Fernandez et al (2010, 2011, 2013a, 2013b, 2013c, 2014) dos anos de 2010 a 2014.

d) O Modelo 4, baseado no IAPM, idêntico ao Modelo 3, à exceção do prêmio de risco do mercado americano, em que foi utilizada a média de 2010 a 2014 dos prêmios indicados por Damodaran.

Como taxa livre de risco brasileira para os quatro modelos adotou-se a taxa média de 2 anos das LTNs. O período considerado abrangeu de 2010 a 2014. A Tabela 58 apresenta as estimativas para o custo de capital.

Tabela 58 - Estimativa do custo de capital próprio

\begin{tabular}{lccccc}
\hline Variável & Notação & Modelo 1 & Modelo 2 & Modelo 3 & Modelo 4 \\
\hline$\beta_{\text {BANCOS / IBOVESPA }}$ & $\beta_{i}^{k}$ & 0,7674 & 0,7674 & 0,7674 & 0,7674 \\
$\beta_{\text {IBOVESPA / S\&P500 }}$ & $\beta_{k}^{G L}$ & - & - & 1,2324 & 1,2324 \\
$\mathrm{R}_{\mathrm{F}} \mathrm{BR}$ & $r_{f}^{B R}$ & $10,96 \%$ & $10,96 \%$ & $10,96 \%$ & $10,96 \%$ \\
$\left(\mathrm{R}_{\mathrm{M}}-\mathrm{R}_{\mathrm{F}}\right)_{\text {EUA }}$ & $E\left(r_{m}^{G L}\right)-r_{f}^{G L}$ & & & $5,62 \%$ & $5,51 \%$ \\
$\left(\mathrm{R}_{\mathrm{M}}-\mathrm{R}_{\mathrm{F}}\right)_{\mathrm{BR}}$ & & $7,34 \%$ & $8,30 \%$ & - & - \\
$\mathrm{K}_{\mathrm{E}}$ nominal em Reais (\% a.a.) & $E\left(r_{i}^{k}\right)$ & $16,59 \%$ & $17,33 \%$ & $16,28 \%$ & $16,17 \%$ \\
\hline
\end{tabular}

Note-se a boa convergência de resultados entre os modelos. A maior discrepância foi observada no modelo 2, em função do maior prêmio de risco para o mercado brasileiro considerado por Damodaran. Os outros três modelos apresentam resultados muito próximos. Desta forma, foi descartado o resultado do modelo 2 e considerada a média dos modelos 1, 3 e 4, que corresponde a 16,35\% a.a.. Esse será o valor adotado a título de custo de capital.

\subsection{Estimativa do porte mínimo das instituições financeiras}

Nesta seção é apresentada a consolidação dos itens 5.5 e 5.6, ou seja, estimou-se qual o porte da instituição a partir do qual o ROE é superior ao custo de capital.

A Tabela 59 resume os coeficientes dos modelos definidos no item 5.5. que apresentaram 
significância de $5 \%$.

Tabela 59 - Resultado com significância das regressões

\begin{tabular}{lcccc}
\hline Variável & $\begin{array}{c}\text { Bancos } \\
\text { Comerciais }\end{array}$ & $\begin{array}{c}\text { Bancos de } \\
\text { Investimento }\end{array}$ & Financeiras & $\begin{array}{c}\text { Soc. de Crédito } \\
\text { Imobiliário }\end{array}$ \\
\hline ln_pl & 0,214366 & 0,190167 & 0,286166 & 0,468545 \\
sem1 & 0,082186 & 0,000000 & 0,000000 & 0,000000 \\
sem2 & 0,075878 & 0,115603 & 0,000000 & 0,000000 \\
sem3 & 0,052463 & 0,000000 & 0,000000 & 0,000000 \\
sem4 & 0,000000 & 0,000000 & 0,000000 & 0,000000 \\
sem5 & 0,000000 & 0,000000 & 0,000000 & 0,000000 \\
sem6 & 0,000000 & 0,000000 & 0,000000 & 0,000000 \\
sem7 & 0,000000 & $-0,057520$ & 0,000000 & 0,000000 \\
sem8 & 0,000000 & 0,000000 & 0,000000 & 0,000000 \\
sem9 & 0,000000 & 0,000000 & 0,000000 & 0,000000 \\
constante & $-2,786203$ & $-2,267360$ & $-2,779228$ & $-4,515471$ \\
\hline
\end{tabular}

Os Gráficos 27 a 30 mostram a intersecção das curvas de retorno com a do custo de capital. Não foram consideradas as variáveis dummies, ou seja, os resultados consideram o cenário econômico de dezembro de 2014. Lembrando, o custo de capital não apresentou significância para o patrimônio líquido, justificando assim o valor de $\mathrm{K}_{\mathrm{E}}$ constante.

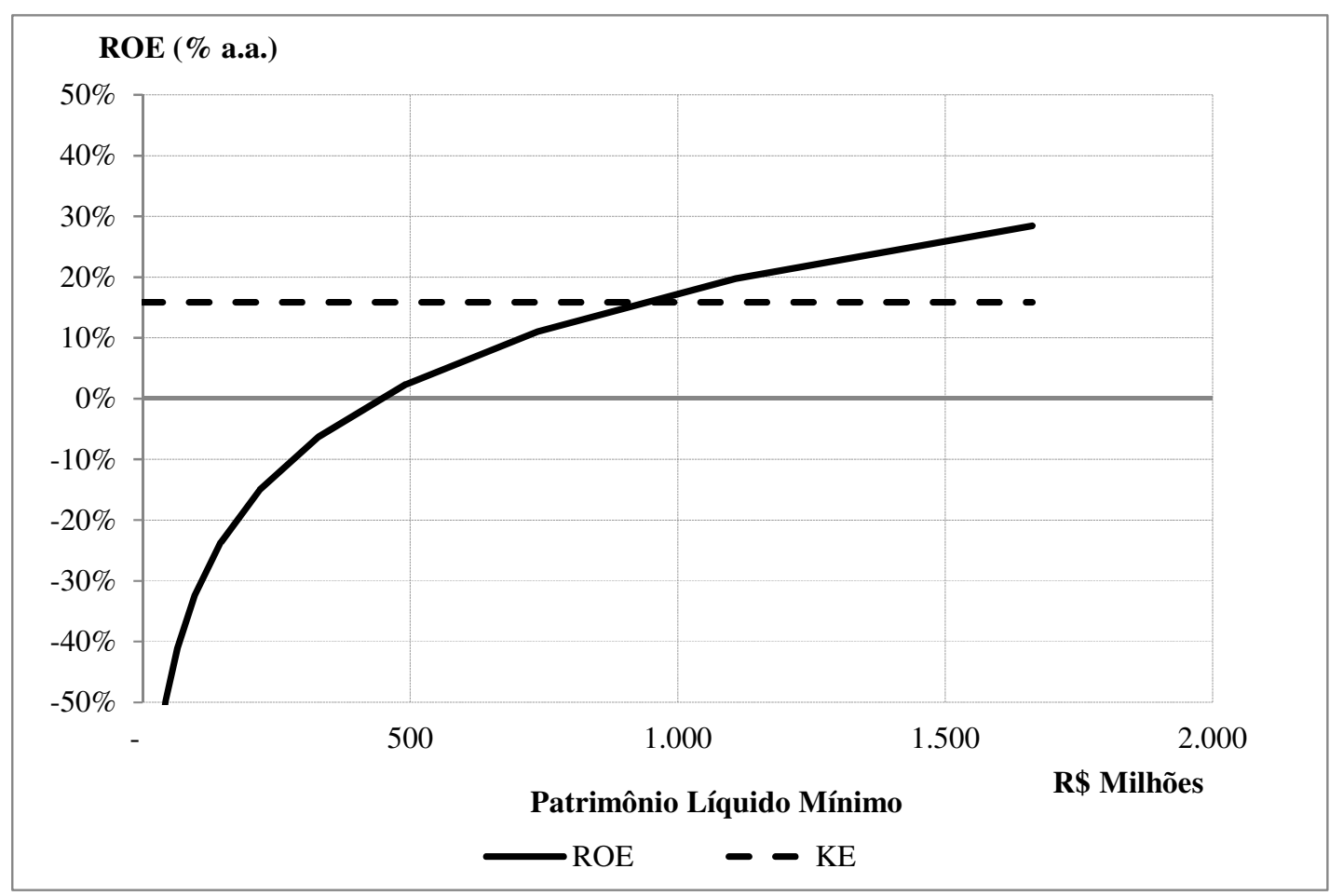

Gráfico 27 - Bancos comerciais: curva de retorno x patrimônio líquido 


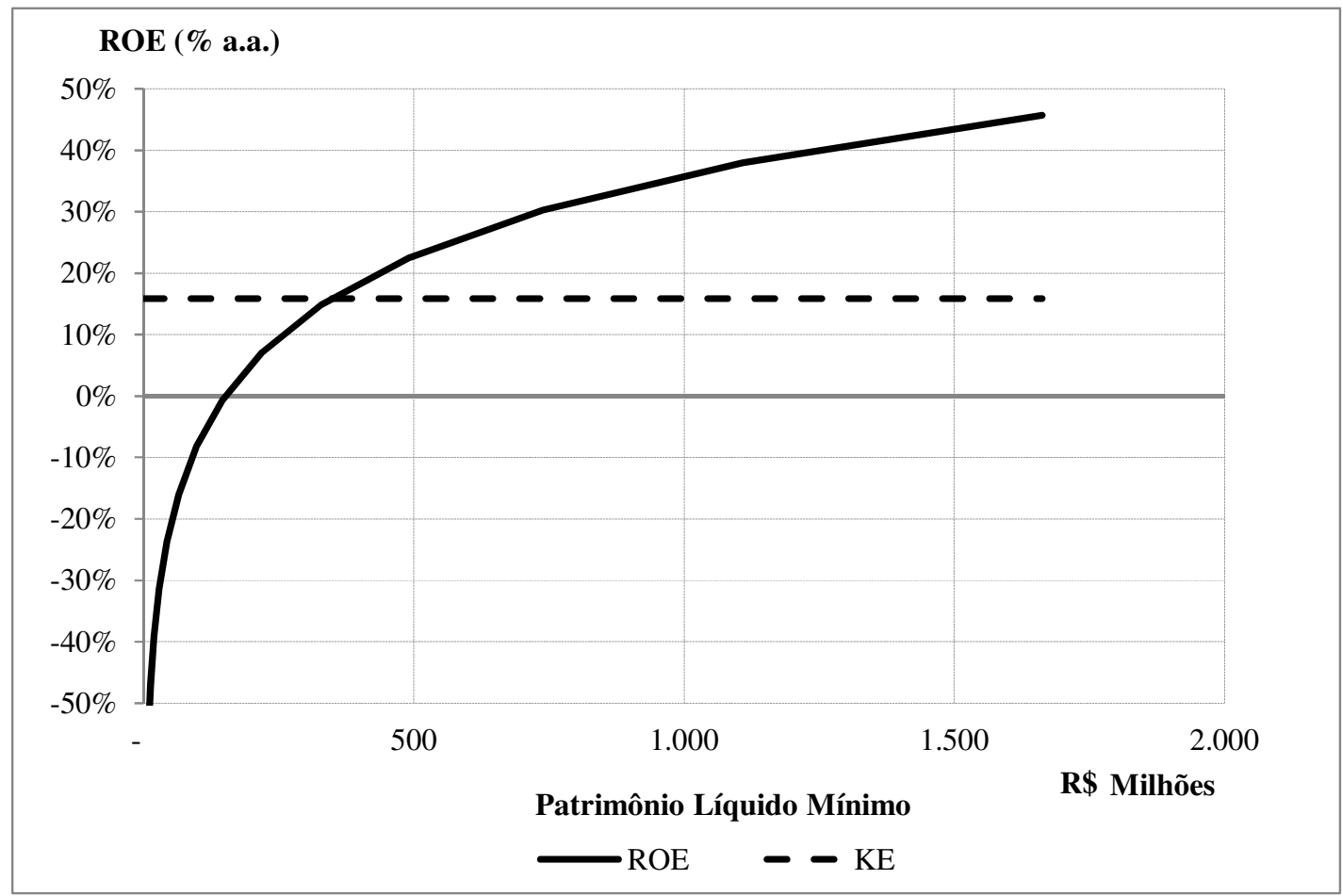

Gráfico 28 - Bancos de investimento: curva de retorno x patrimônio líquido

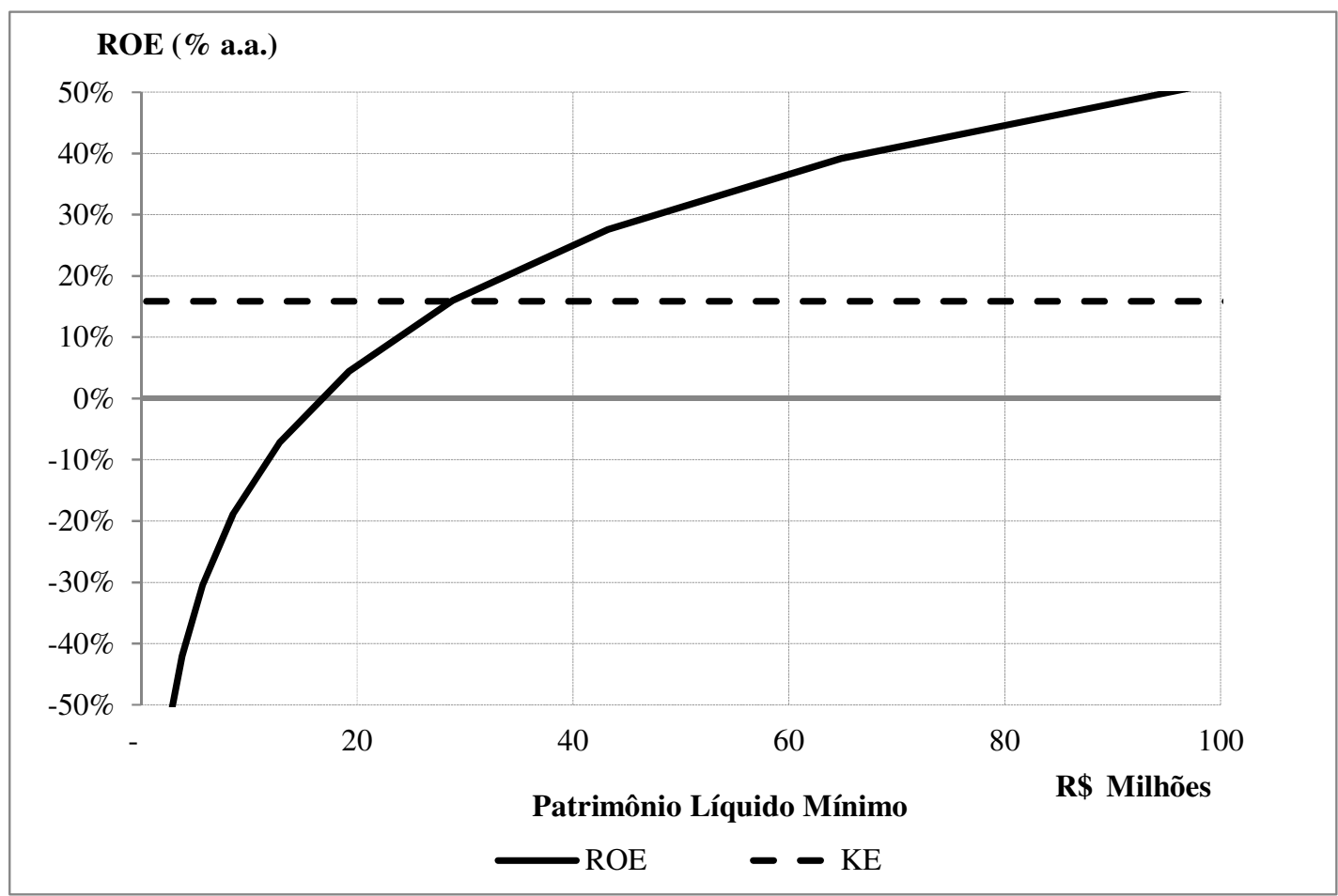

Gráfico 29 - Financeiras: curva de retorno x patrimônio líquido 


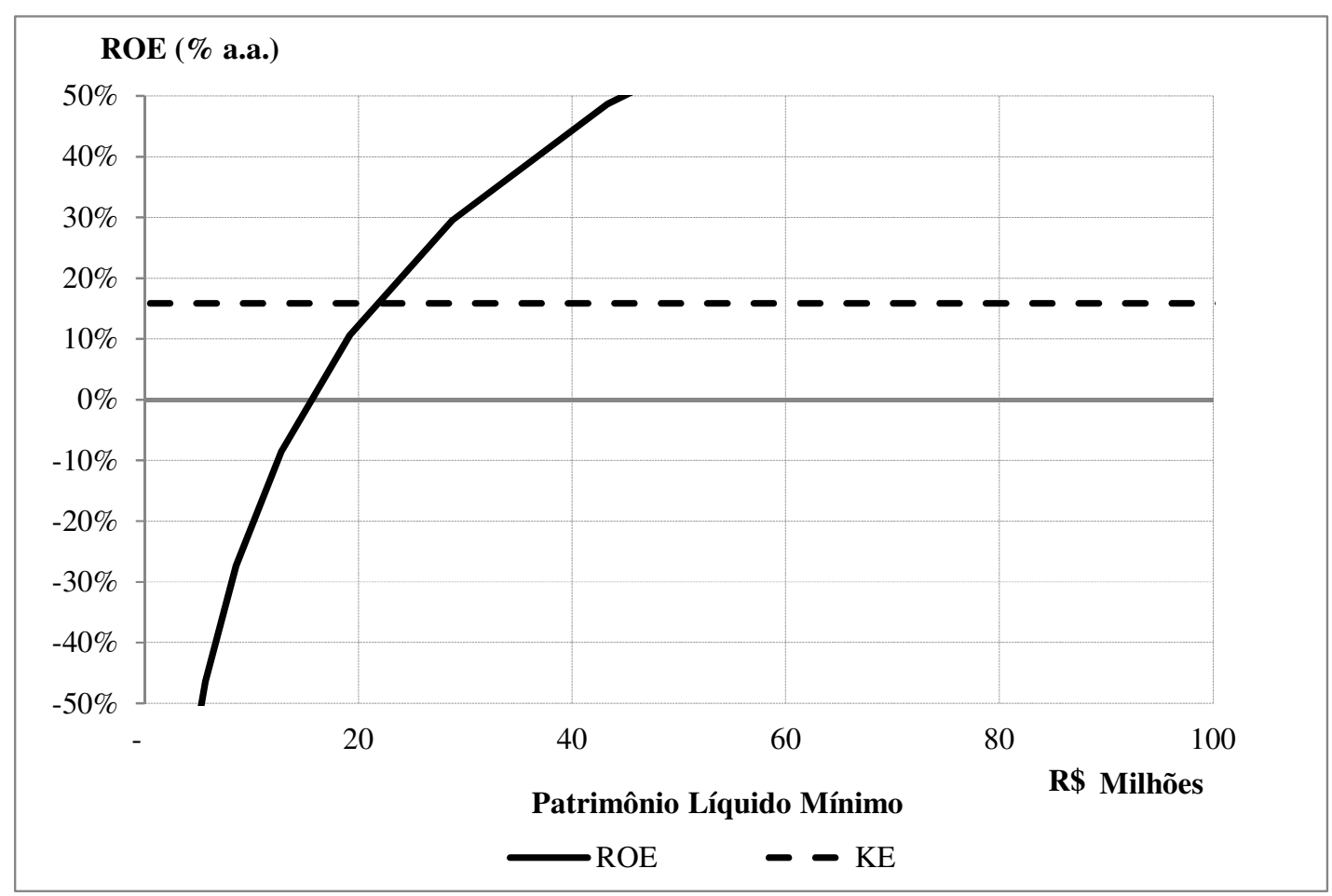

Gráfico 30 - Sociedades de crédito imobiliário: curva de retorno x patrimônio líquido

Pode-se também obter o valor do Patrimônio Líquido Mínimo por meio algébrico, partindo-se da equação (6), página 66, e isolando-se o patrimônio líquido, como apresentado na equação (18):

$$
p l=e^{\left(\frac{\text { ROE }-\alpha-\beta_{2} \text { Alavanc }_{3} \beta_{3} \text { Alavanc }^{2}-\theta_{1} \operatorname{sem}_{1} \cdots \theta_{9} \text { sem }_{9}}{\beta_{1}}\right)}
$$

Fazendo-se ROE igual ao custo de capital $\mathrm{K}_{\mathrm{E}}$ de $16,35 \%$ a.a., e substituindo-se pelos coeficientes da Tabela 59, tem-se os valores de patrimônio líquido, em função do semestre considerado, como apresentado na Tabela 60. 
Tabela 60 - Valor do Patrimônio Líquido Mínimo, em função do cenário

\begin{tabular}{ccccc}
\hline Semestre & $\begin{array}{c}\text { Bancos } \\
\text { Comerciais }\end{array}$ & $\begin{array}{c}\text { Bancos de } \\
\text { Investimento }\end{array}$ & Financeiras & $\begin{array}{c}\text { Soc. de Crédito } \\
\text { Imobiliário }\end{array}$ \\
\hline $1^{\mathbf{o}}$ semestre 2010 & 644.825 & 356.028 & 29.240 & 21.724 \\
$2^{\mathbf{o}}$ semestre 2010 & 664.082 & 193.854 & 29.240 & 21.724 \\
$1^{\mathbf{o}}$ semestre 2011 & 740.729 & 356.028 & 29.240 & 21.724 \\
$2^{\mathbf{o}}$ semestre 2011 & 946.120 & 356.028 & 29.240 & 21.724 \\
$1^{\mathbf{o}}$ semestre 2012 & 946.120 & 356.028 & 29.240 & 21.724 \\
$2^{\mathbf{o}}$ semestre 2012 & 946.120 & 356.028 & 29.240 & 21.724 \\
$1^{\mathbf{o}}$ semestre 2013 & 946.120 & 481.777 & 29.240 & 21.724 \\
$2^{\mathbf{o}}$ semestre 2013 & 946.120 & 356.028 & 29.240 & 21.724 \\
$1^{\mathbf{o}}$ semestre 2014 & 946.120 & 356.028 & 29.240 & 21.724 \\
$2^{\mathbf{o}}$ semestre 2014 & 946.120 & 356.028 & 29.240 & 21.724 \\
\hline
\end{tabular}

Nota: Valores em R \$1.000,00

A Tabela 61 traz os valores mínimos de Patrimônio Líquido estabelecidos pelo BACEN. É importante notar que qualquer que seja o cenário dentro do período analisado, os valores de patrimônio líquido mínimo serão sempre superiores aos que estão em vigor.

Tabela 61 - Valores Mínimos de Patrimônio Líquido estabelecidos pelo BACEN

\begin{tabular}{lc}
\hline Modalidade & Capital \\
\hline Banco comercial & $\mathrm{R} \$ 17.500 .000,00$ \\
Banco de investimento & $\mathrm{R} \$ 12.500 .000,00$ \\
Sociedade de crédito, financiamento e investimento (financeira) & $\mathrm{R} \$ 7.000 .000,00$ \\
Sociedades de crédito imobiliário & $\mathrm{R} \$ 7.000 .000,00$ \\
\hline
\end{tabular}

Deve-se considerar também que vários bancos que compõem a base de dados, principalmente no caso dos bancos com carteira comercial, são bancos múltiplos que possuem diversas carteiras. Se for considerada uma instituição com carteira de banco comercial, de investimento, de financeira, de arrendamento mercantil e de crédito imobiliário, o capital mínimo requerido seria a soma dos capitais mínimos, o que corresponde a $\mathrm{R} \$ 51$ milhões. Mesmo assim, o capital regulatório mínimo é consideravelmente inferior ao que é sugerido neste trabalho.

A Tabela 62 foi construída para medir a sensibilidade do valor mínimo ao custo de capital, para o que fixou-se o $2^{\circ}$ semestre de 2014 como referência, e fez-se variar o $\mathrm{K}_{\mathrm{E}}$. 
Tabela 62 - Valor do Patrimônio Líquido Mínimo, em função do custo de capital

\begin{tabular}{ccccc}
\hline Custo de Capital & $\begin{array}{c}\text { Bancos } \\
\text { Comerciais }\end{array}$ & $\begin{array}{c}\text { Bancos de } \\
\text { Investimento }\end{array}$ & Financeiras & $\begin{array}{c}\text { Soc. de Crédito } \\
\text { Imobiliário }\end{array}$ \\
\hline $0,00 \%$ & 441.269 & 150.692 & 16.514 & 15.325 \\
$2,00 \%$ & 484.421 & 167.404 & 17.709 & 15.993 \\
$4,00 \%$ & 531.792 & 185.969 & 18.991 & 16.690 \\
$6,00 \%$ & 583.796 & 206.593 & 20.366 & 17.418 \\
$8,00 \%$ & 640.884 & 229.504 & 21.840 & 18.178 \\
$10,00 \%$ & 703.556 & 254.956 & 23.421 & 18.971 \\
$12,00 \%$ & 772.356 & 283.231 & 25.117 & 19.798 \\
$14,00 \%$ & 847.884 & 314.641 & 26.935 & 20.661 \\
$16,00 \%$ & 930.798 & 349.535 & 28.884 & 21.562 \\
$18,00 \%$ & 1.021 .820 & 388.299 & 30.975 & 22.503 \\
$20,00 \%$ & 1.121 .744 & 431.361 & 33.218 & 23.484 \\
\hline
\end{tabular}

Nota: Valores em R\$1.000,00

Conclui-se que, mesmo que se admita custo de capital nulo, o que é absolutamente irreal, os valores de patrimônio líquido mínimo serão sempre superiores aos que estão em vigor, mostrados no Quadro 2. Desta observação, pode-se concluir que as despesas administrativas a que as instituições estão sujeitas são de tal ordem que a escala necessária para que um banco comercial proporcione retorno nulo ao acionista parte de um patrimônio líquido de 441 milhões de reais.

Do exposto, fica comprovada a hipótese de que os valores de patrimônio líquido mínimo em vigor estão muito defasados, o que sugere a necessidade de revisão da política existente. 


\section{CONCLUSÕES}

Este trabalho teve como objetivo avaliar se os valores mínimos de patrimônio líquido, estabelecidos pelo Banco Central do Brasil, resultam em instituições financeiras capazes de arcar com a estrutura de custos e de remunerar adequadamente o capital dos acionistas. Desta forma, a hipótese de pesquisa foi a avaliação da adequação da referida norma.

Foram pesquisados na literatura estudos sobre diferentes aspectos da indústria bancária, envolvendo a eficiência, a escala, o custo de observância à normas e o ambiente competitivo. Os estudos sobre os bancos americanos apontaram que as instituições de menor porte são possuidoras de maior eficiência e maior capacidade de obtenção de ganhos de escala; no entanto, os resultados obtidos para os bancos brasileiros apontam em sentido contrário e indicam, inclusive, que os retornos observados são menores, comparativamente aos grandes conglomerados financeiros. Isso levanta a hipótese de que as condições de competitividade das instituições de menor porte no Brasil possam ser mais desfavoráveis, o que suscita a necessidade de investigar a partir de que porte os bancos passam a ser viáveis.

Foram pesquisados dados do Consolidado Bancário de dezembro de 2014 e constatou-se que os cinco maiores conglomerados financeiros detêm parcela de $70 \%$ das operações de crédito, $79 \%$ dos depósitos e $65 \%$ dos resultados operacionais do Sistema Financeiro Nacional. Este nível de concentração bancária corrobora com a hipótese de que as condições de competitividade das instituições menores sejam desfavoráveis. E, de fato, constatou-se também que no mesmo período o retorno sobre o patrimônio líquido desses cinco bancos foi muito superior ao apresentado pelos demais bancos.

Constatou-se também que uma minoria dos bancos constituídos em passado recente tem conseguido remunerar seus acionistas dentro de suas expectativas.

No tocante à estrutura de custos, as instituições financeiras são obrigadas a manter infraestruturas tecnológicas e estruturas de gestão muito onerosas, o que torna importante a diluição desses custos por uma base maior de ativos. Desta forma, suscitou-se a hipótese de que a relação entre as despesas operacionais e o patrimônio líquido possa ser inversamente proporcional ao porte da instituição, medido pelo valor do patrimônio líquido. Para tanto, as 
instituições foram classificadas em clusters, de acordo com seu porte, e calculou-se a média desta relação para cada cluster. Verificou-se que, para os bancos com carteira comercial e de investimento, a relação entre as despesas operacionais e o patrimônio líquido reduz-se com o aumento do tamanho da instituição; logo, é razoável suspeitar que os bancos de menor porte têm condições mais desfavoráveis para alcançar a economia de escala necessária que lhes permita oferecer aos investidores taxas de retorno compatíveis.

Pesquisou-se junto ao Banco Central do Brasil as restrições existentes no que tange à escala das operações. Mostrou-se que as normas de capital regulatório impõem uma relação mínima entre o patrimônio líquido e os ativos ponderados pelo risco. Desta forma, a escala das operações, em termos do volume da carteira de ativos, é limitada pelo valor do patrimônio líquido.

Para comprovar a hipótese de que valor mínimo de patrimônio líquido estabelecido em norma está subdimensionado, procurou-se estimar qual seria este valor, de acordo com a modalidade de instituição financeira, respeitada a condição de que o retorno deva ser igual ou superior ao custo de capital próprio, estimado pelo CAPM.

A metodologia utilizada baseou-se em regressões de dados em painel estático, tendo como variável dependente o retorno sobre o patrimônio líquido; e como variáveis explicativas o patrimônio líquido, a alavancagem bancária e variáveis dummies de tempo, para refletir o cenário econômico existente em cada semestre. Estas regressões definiram, portanto, um modelo de estimação do ROE em função do patrimônio líquido. A comprovação da hipótese de pesquisa foi obtida pela estimação do patrimônio líquido que fornece um ROE igual ao custo de capital próprio, e pela comparação entre esse patrimônio e o estabelecido em norma.

Como resultado, foram obtidos valores de patrimônio líquido consideravelmente superiores aos limites mínimos do Banco Central para os bancos com carteira comercial, bancos com carteira de investimento, financeiras e sociedades de crédito imobiliário.

Estes resultados sugerem que o Banco Central faça a revisão dos limites de patrimônio líquido, possibilitando instituições sustentáveis, no que tange à sua capacidade de atrair capitais. 
Por outro lado, a ordem de grandeza dos limites sugeridos para bancos comerciais e de investimento podem ser muito restritivos, e limitariam o acesso ao Sistema Financeiro Nacional para um grande número de grupos econômicos. Isto é particularmente sério quando levamos em conta a concentração bancária no Brasil, em que a maior parte dos ativos e dos depósitos é detida por poucos bancos.

Cabe ao Banco Central do Brasil a busca do equilíbrio entre instituições sustentáveis em termos econômicos e os benefícios decorrentes do estímulo ao ambiente competitivo com a aprovação de um maior número de instituições.

Não se considerou neste trabalho que a constituição de uma instituição financeira, dentro da estrutura organizacional de grandes grupos industriais e/ou comerciais, possa ser uma estratégia que vise eliminar as barreiras para o crescimento do grupo e elevar seu retorno consolidado; nesta situação, olhar-se isoladamente para o retorno da instituição pode representar um erro, por não considerar o valor que a instituição adicionou aos demais negócios.

Adicionalmente, este trabalho sugere à autoridade monetária uma metodologia voltada para a definição da política de valores mínimos. É possível incorporar variáveis explicativas do retorno dos bancos, como por exemplo: a taxa de juros, a taxa de inadimplência, variação do Produto Interno Bruto, etc. Um modelo com estas características possibilitaria inclusive fazer simulações sobre o impacto decorrente de mudanças dessas variáveis sobre o resultado das instituições financeiras. Outra possibilidade é a simulação do modelo, com diferentes níveis de custo de capital, inclusive adotando-se arbitrariamente um coeficiente para o efeito tamanho.

\subsection{Sugestão para futuros trabalhos}

A base de dados obtida junto ao sítio do BACEN abre a porta para uma série de investigações. Algumas informações desta base foram apresentadas nas estatísticas descritivas deste trabalho, e justificam uma análise com maior profundidade. A análise de muitas destas variáveis pode contribuir para explicar a relação entre o retorno e o porte das instituições. 
Um primeiro estudo sugerido diz respeito à relação entre as despesas administrativas e o porte das instituições. Nas estatísticas descritivas foi identificado que, para os bancos comerciais e de investimento, a relação entre despesas administrativas e o patrimônio decresce quando o porte da instituição cresce. Esta constatação sugere que se investigue, por meio de métodos econométricos, a significância desta relação.

Um segundo estudo recomendado consiste na averiguação da relação entre o porte das instituições e o mix entre receitas de intermediação e receitas com tarifas e serviços. É senso comum que os bancos de maior porte prestam inúmeros serviços de transferência de recursos, conta correte, cobrança, etc. Este trabalho tangenciou esse aspecto nas estatísticas descritivas, e estudos com maior profundidade irão fornecer uma melhor compreensão do retorno dos bancos.

Em terceiro lugar sugere-se um estudo sobre a taxa média de aplicação, de captação e sobre o spread bancário. Alguns teóricos sugerem que, com o intuito de conceder crédito, os bancos de menor porte são mais eficazes no uso de soft information que os bancos de maior porte. Os estudos que deram origem a esta informação baseiam-se em sua grande maioria no mercado americano. Por outro lado, bancos de maior porte são vistos como instituições de menor risco, o que pode fazer com que seu custo de captação seja inferior. A análise dessas variáveis poderá contribuir consideravelmente para a compreensão dos resultados com intermediação financeira das instituições.

Em quarto lugar recomenda-se estudo sobre a relação entre o nível de imobilização e o porte das instituições. A imobilização é tema de atenção dos bancos centrais, que inclusive estabelecem limites operacionais para os bancos. Isto se justifica pelo fato de que um elevado nível de imobilização compromete a capacidade de fazer caixa e resgatar os recursos de seus depositantes. Mas talvez estes limites devam ser ajustados a outras variáveis. Viu-se nas estatísticas descritivas que grandes bancos imobilizam mais que os de menor porte. As razões para isto podem decorrer das redes de agências que possuem, ou de sua infraestrutura tecnológica. Se uma parte significativa das receitas dos grandes conglomerados financeiros decorre de tarifas e floats, isto talvez sirva de justificativa para adequar o limite de imobilização ao porte ou ao perfil da instituição.

Em quinto lugar sugere-se a incorporação de outras variáveis explicativas do retorno das 
instituições financeiras ao modelo utilizado, o que permitiria simular o efeito de mudanças econômicas sobre o retorno. Um modelo desta natureza seria de grande valor ao Banco Central em seu papel de assegurar a solvabilidade do Sistema Financeiro Nacional. 
ADAMS, Renée B.; MEHRAN, Hamid. Is corporate governance different for bank holding companies?. Available at SSRN 387561, 2003.

ADLER, Michael; SOLNIK, Bruno H. The international pricing of risk: an empirical investigation of the world capital market structure. The Journal of Finance, v. 29, n. 2, p. 365-378, 1974.

ADRIAN, Tobias; SHIN, Hyun Song. The shadow banking system: implications for financial regulation. Staff Report, n. 382, Federal Reserve Bank of New York, 2009.

AGÊNCIA NATIONAL DE TELECOMUNICAÇÕES - ANATEL. Resolução n 535, de 21 de outubro de 2009.

AGÊNCIA REGULADORA DE SANEAMENTO E ENERGIA DO ESTADO DE SÃO PAULO - ARSESP. Nota técnica ${ }^{\circ}$ RTS/01/2011 - Definição de Metodologia e Cálculo do Custo Médio Ponderado de Capital (WACC). Março de 2011.

AKHIGBE, Aigbe; MCNULTY, James E. Bank monitoring, profit efficiency and the commercial lending business model. Journal of Economics and Business, v. 63, n. 6, p. 531$551,2011$.

AKHIGBE, Aigbe; MCNULTY, James E. The profit efficiency of small US commercial banks. Journal of Banking \& Finance, v. 27, n. 2, p. 307-325, 2003.

ALTUNBAS, Yener; LIU, Ming-Hau; MOLYNEUX, Philip; SETH, Rama. Efficiency and risk in Japanese banking. Journal of Banking \& Finance, v. 24, n. 10, p. 1605-1628, 2000.

ARANTES, Thiago Maciel; ROCHA, Bruno de Paula. Eficiência dos bancos brasileiros e os impactos da crise financeira global de 2008. In: $\mathbf{4 0}^{\circ}$ Encontro Nacional de Economia ANPEC. Porto de Galinhas (PE), 2012. Disponível em <http://www.anpec. org.br/encontro/2012/inscricao/files_I/i7-86ea8cbb7078fccc8ed41b25bdde1887.pdf>. Acesso em 16/06/2014.

BANCO CENTRAL DO BRASIL - BACEN. Balancetes das instituições financeiras. Disponível em < http://www4.bcb.gov.br/fis/cosif/balancetes.asp>. Acesso em 23/04/2015.

BANCO CENTRAL DO BRASIL - BACEN. Discurso do Presidente do Banco Central do Brasil, Ministro Alexandre Tombini, na cerimônia de lançamento do Programa Otimiza BC. Brasília, 19/02/2013a. Disponível em <http://www.bcb.gov.br/pec/appron/apres/Discurso _Alexandre_Tombini_Otimiza_BC_19-02-2013.pdf>. Acesso em 07/03/2015.

Relatório de Estabilidade Financeira. Brasília, setembro de 2014a. 
. Relatório de Estabilidade Financeira. Brasília, outubro de 2015a.

. Resolução no 2.099. Brasília, 17 de agosto de 1994.

Resolução no 2.607. Brasília, 27 de maio de 1999.

Resolução $\mathbf{N}^{\circ}$ 3.426. Brasília, 21 de dezembro de 2006.

. Resolução no 3.444. Brasília, 28 de fevereiro de 2007a.

. Resolução no 3.490. Brasília, 29 de agosto de 2007b.

Resolução no 3.721. Brasília, 30 de abril de 2009.

Resolução no 3.932. Brasília, 16 de dezembro de 2010.

Resolução no 4.192. Brasília, $1^{\circ}$ de março de 2013a.

Resolução no 4.193. Brasília, $1^{\circ}$ de março de 2013 b.

Resolução no 4.278. Brasília, 31 de outubro de 2013c.

Resolução no 4.311. Brasília, 20 de fevereiro de 2014b.

BANZ, Rolf $\mathrm{W}$. The relationship between return and market value of common stocks. Journal of Financial Economics, v. 9, n. 1, p. 3-18, 1981.

BASLE COMMITTEE ON BANKING SUPERVISION - BCBS. A brief history of the Basel Committee. Basle, Oct. 2014.

BASLE COMMITTEE ON BANKING SUPERVISION - BCBS. A global regulatory framework for more resilient banks and banking systems. Basle, June 2011.

. Asset transfers and securitisation. Basle, September 1992.

. Corporate governance principles for banks. Basle, Oct.2014b.

. Enhancing corporate governance for banking organizations. Basle, Feb.2006.

. International Convergence of Capital Measurement and Capital Standards. Basle, Jul.1988.

International Convergence of Capital Measurement and Capital Standards - A

Revised Framework. Basle, Nov.2005. 
Principles for enhancing corporate governance. Basle, Oct.2010.

BERGER, Allen N.; BLACK, Lamont K. Bank size, lending technologies, and small business finance. Journal of Banking \& Finance, v. 35, n. 3, p. 724-735, 2011.

BERGER, Allen N.; DEYOUNG, Robert. Problem loans and cost efficiency in commercial banks. Journal of Banking \& Finance, v. 21, n. 6, p. 849-870, 1997.

BERGER, Allen N.; HANCOCK, Diana; HUMPHREY, David B. Bank efficiency derived from the profit function. Journal of Banking \& Finance, v. 17, n. 2, p. 317-347, 1993.

BERGER, Allen N.; HANWECK, Gerald A.; HUMPHREY, David B. Competitive viability in banking: Scale, scope, and product mix economies. Journal of Monetary Economics, v. 20, n. 3, p. 501-520, 1987.

BERGER, Allen N.; HUMPHREY, David B. Efficiency of financial institutions: International survey and directions for future research. European journal of operational research, v. 98, n. 2, p. 175-212, 1997.

BERGER, Allen N.; HUMPHREY, David B. Bank scale economies, mergers, concentration, and efficiency: the US experience. The Wharton Financial Institutions Center, 1994.

BERGER, Allen N.; HUNTER, William C.; TIMME, Stephen G. The efficiency of financial institutions: a review and preview of research past, present and future. Journal of Banking \& Finance, v. 17, n. 2, p. 221-249, 1993.

BERGER, Allen N.; MESTER, Loretta J. Inside the black box: What explains differences in the efficiencies of financial institutions? Journal of Banking \& Finance, v. 21, n. 7, p. 895947, 1997.

BERGER, Allen N.; MILLER, Nathan H.; PETERSEN, Mitchell A.; RAJAN, Raghuram G.; STEIN, Jeremy C. Does function follow organizational form? Evidence from the lending practices of large and small banks. Journal of Financial Economics, v. 76, n. 2, p. 237-269, 2005.

BERTRAND, Marianne; SCHOAR, Antoinette; THESMAR, David. Banking deregulation and industry structure: Evidence from the French banking reforms of 1985. The Journal of Finance, v. 62, n. 2, p. 597-628, 2007.

BIANCONI, Marcelo; YOSHINO, Joe A. Firm market performance and volatility in a national real estate sector. International Review of Economics \& Finance, v. 22, n. 1, p. 230-253, 2012.

BLUM, Denis; NAKANE, M. O impacto de requerimentos de capital na oferta de crédito bancário no Brasil. Anais do XXXIII Encontro Nacional de Economia, 2005. 
CARTER, David A.; MCNULTY, James E.; VERBRUGGE, James A. Do small banks have an advantage in lending? An examination of risk-adjusted yields on business loans at large and small banks. Journal of Financial Services Research, v. 25, n. 2-3, p. 233-252, 2004.

CAVALLO, Laura; ROSSI, Stefania PS. Scale and scope economies in the European banking systems. Journal of Multinational Financial Management, v. 11, n. 4, p. 515-531, 2001.

CERETTA, Paulo Sergio; NIEDERAUER, Carlos Alberto Pittaluga. Rentabilidade e eficiência no setor bancário brasileiro. Revista de Administração Contemporânea, v. 5, n. 3, p. 7-26, 2001.

CLARK, Jeffrey A. Economic cost, scale efficiency, and competitive viability in banking. Journal of Money, Credit and Banking, p. 342-364, 1996.

COHEN, Benjamin H. How have banks adjusted to higher capital requirements? B.I.S. Quarterly Review, v. 17, p. 25-41, 2013.

COPELAND, Thomas E.; WESTON, John Fred; SHASTRI, Kuldeep.Financial theory and corporate policy. $4^{\mathrm{a}}$ ed. Pearson Addison-Wesley, 2005.

DAMODARAN, Aswath. Equity Risk Premiums (ERP): Determinants, Estimation and Implications - A Post-Crisis Update. Financial Markets, Institutions \& Instruments, v. 18, n. 5, p. 289-370, 2009.

Equity Risk Premiums (ERP): Determinants, Estimation and Implications - The 2013 Edition. New York University - Stern School of Business. March 2013.

Risk Premiums for Other Markets - 01/10. Disponível em <http://www.stern.nyu.edu/ adamodar/pc/archives/ctryprem09.xls $>$. Acesso em 17 de dezembro de 2015.

Risk Premiums for Other Markets - 01/11. Disponível em $<$ http://www.stern.nyu.edu/ adamodar/pc/archives/ctryprem10.xls $>$. Acesso em 17 de dezembro de 2015.

Risk Premiums for Other Markets - 01/12. Disponível em $<$ http://www.stern.nyu.edu/ adamodar/pc/archives/ctryprem11.xls $>$. Acesso em 17 de dezembro de 2015.

Risk Premiums for Other Markets - 01/13. Disponível em $<$ http://www.stern.nyu.edu/ adamodar/pc/archives/ctryprem12.xls $>$. Acesso em 17 de dezembro de 2015.

Risk Premiums for Other Markets - 01/14. Disponível em $<$ http://www.stern.nyu.edu/ adamodar/pc/archives/ctryprem13.xls $>$. Acesso em 17 de dezembro de 2015. 
. Risk Premiums for Other Markets - 01/15. Disponível em

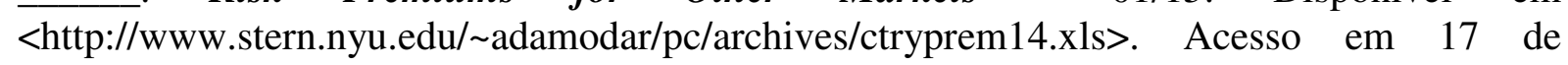
dezembro de 2015.

Total Betas by Sector. Disponível em <http://www.stern. nyu.edu/ adamodar/pc/datasets/totalbeta.xls>. Acesso em 17 de dezembro de 2015.

DE PAULA, Luiz Fernando; FARIA, João. A. de. Expansão do crédito e eficiência do setor bancário brasileiro. Valor Econômico. São Paulo, 28/12/2007.

DE PAULA, Luiz Fernando; MARQUES, Maria Beatriz L. Tendências recentes da consolidação bancária no Brasil. Análise Econômica, v. 24, n. 45, 2004.

DE PAULA, Luiz Fernando; OREIRO, José Luís; BASÍLIO, Flavio AC. Estrutura do setor bancário e o ciclo recente de expansão do crédito: O papel dos bancos públicos federais. Nova Economia, v. 23, n. 3, 2014.

DEMSETZ, Rebecca S.; STRAHAN, Philip E. Diversification, size, and risk at bank holding companies. Journal of Money, Credit, and Banking, p. 300-313, 1997.

ELLIEHAUSEN, Gregory. Cost of Bank Regulation: A Review of the Evidence. The Federal Reserve Bulletin, v. 84, p. 252, 1998.

ELLIOTT, Douglas; SALLOY, Suzanne; SANTOS, Andre. Assessing the cost of financial regulation. International Monetary Fund, 2012.

ELTON, Edwin J.; GRUBER, Martin J.; BROWN, Stephen J.; GOETZMANN, William N. Moderna teoria de carteiras e análise de investimentos. São Paulo: Atlas, 2004.

FAMA, Eugene F.; FRENCH, Kenneth R. The cross-section of expected stock returns. The Journal of Finance, v. 47, n. 2, p. 427-465, 1992.

FAMA, Eugene F.; MACBETH, James D. Risk, return, and equilibrium: Empirical tests. The Journal of Political Economy, p. 607-636, 1973.

FÁVERO, Luiz Paulo. Análise de dados: modelos de regressão com Excel, Stata e SPSS. Rio de Janeiro: Elsevier, 2015.

FÁVERO, Luiz Paulo; BELFIORI, Patrícia; SILVA, Fabiana Lopes da; CHAN, Betty Lilian. Análise de dados: modelagem multivariada para a tomada de decisões. Rio de Janeiro: Elsevier, 2009.

FERNANDEZ, Pablo. Equity premium: historical, expected, required and implied. Unpublished working paper, IESE Business School, 2006. 
FERNANDEZ, Pablo; AGUIRREAMALLOA, Javier; AVENDAÑO, Luis Corres. Market risk premium used in 56 countries in 2011: a survey with 6,014 answers. Working paper $\mathrm{n}^{\circ}$ 920, IESE Business School, 2011.

FERNANDEZ, Pablo; AGUIRREAMALLOA, Javier; AVENDAÑO, Luis Corres. Market Risk Premium used in 82 countries in 2012: a survey with 7,192 answers. IESE Business School, 2013a.

FERNANDEZ, Pablo; AGUIRREAMALLOA, Javier; LINARES, Pablo. Market Risk Premium and Risk Free Rate used for 51 countries in 2013: a survey with 6,237 answers. IESE Business School, June, 2014. Available at SSRN 2450452.

FERNANDEZ, Pablo; DEL CAMPO BAONZA, Javier. Market Risk Premium used in 2010 by Professors: a survey with 1,500 answers. IESE Business School, 2010. Available at SSRN 1606563.

FERNANDEZ, Pablo; LINARES, Pablo; ACIN, Isabel Fernandez. Market Risk Premium in 88 countries in 2014: a survey with 8,228 answers. IESE Business School, 2013b. Available at SSRN 914160.

GARCIA, Marco; GIAMBIAGI, Fabio (Org). Risco e regulação. Elsevier, 2010.

GOETZMANN, William N.; IBBOTSON, Roger G. History and the equity risk premium. Yale School of Management, 2005.

GUISO, Luigi; SAPIENZA, Paola; ZINGALES, Luigi. The Cost of Banking Regulation. Working Paper $n^{\circ}$ 12501. National Bureau of Economic Research.. August 2006.

HAIR JR., J. F.; BLACK, Willian C.; BABIN, Barry J.; ANDERSON, Rolph E.; TATHAM, Ronald L. Análise multivariada de dados. $6^{\mathrm{a}}$ ed. Porto Alegre: Bookman, 2009.

HERRALA, Risto. Forward-looking reaction to bank regulation. Working Paper $\mathrm{n}^{\mathrm{o}} 1645$, European Central Bank. 2014.

HUMPHREY, David B. Why do estimates of bank scale economies differ?.FRB Richmond Economic Review, v. 76, n. 5, p. 38-50, 1990.

HUMPHREY, David B.; PULLEY, Lawrence B. Banks' responses to deregulation: Profits, technology, and efficiency. Journal of Money, Credit, and Banking, p. 73-93, 1997.

JAGTIANI, Julapa; NATHAN, Alli; SICK, Gordon. Scale economies and cost complementarities in commercial banks: On-and off-balance-sheet activities. Journal of Banking \& Finance, v. 19, n. 7, p. 1175-1189, 1995.

JAYARATNE, Jith; WOLKEN, John. How important are small banks to small business lending?: New evidence from a survey of small firms. Journal of Banking \& Finance, v. 23, 
n. 2, p. 427-458, 1999.

KLOMP, Jeroen; HAAN, Jakob de. Banking risk and regulation: Does one size fit all? Journal of Banking \& Finance, v. 36, n. 12, p. 3197-3212, 2012.

LAEVEN, Luc; LEVINE, Ross. Bank governance, regulation and risk taking. Journal of Financial Economics, v. 93, n. 2, p. 259-275, 2009.

LEVINE, Ross. The corporate governance of banks: a concise discussion of concepts and evidence. World Bank Publications, 2004.

LEIBENSTEIN, Harvey. General X-Efficiency Theory and Economic Development. New York: Oxford University Press, 1978.

MARCONI, Marina de Andrade; LAKATOS, Eva Maria. Fundamentos de Metodologia científica. 6.ed. São Paulo: Atlas, 2005.

MCALLISTER, Patrick H.; MCMANUS, Douglas. Resolving the scale efficiency puzzle in banking. Journal of Banking \& Finance, v. 17, n. 2, p. 389-405, 1993.

MICHAEL, Bryane. Playing the Shadowy World of Emerging Market Shadow Banking. Skolkovo Business School-Ernst \& Young Institute for Emerging Market Studies (IEMS), v. 14, 2014.

MILES, David; YANG, Jing; MARCHEGGIANO, Gilberto. Optimal Bank Capital. The Economic Journal, v. 123, n. 567, p. 1-37, 2013.

MOURA, Alkimar. Prefácio In: SOBREIRA, Rogério (Org). Regulação financeira e bancária. Revista de Economia Política, v. 25, p. 3, 2005.

NAKANE, Márcio I.; WEINTRAUB, Daniela B. Bank privatization and productivity: Evidence for Brazil. Journal of Banking \& Finance, v. 29, n. 8, p. 2259-2289, 2005.

NERSISYAN, Yeva; WRAY, L. Randall. The global financial crisis and the shift to shadow banking. Working paper $\mathrm{n}^{\circ}$ 587, Levy Economics Institute of Bard College, 2010.

PETERSEN, Mitchell A. Estimating standard errors in finance panel data sets: Comparing approaches. Review of financial studies, v. 22, n. 1, p. 435-480, 2009.

PETERSEN, Mitchell A. Information: hard and soft. Working paper, Northwestern University, 2004.

PINDYCK, Robert S.; RUBINFELD, Daniel L. Microeconomia. 5a ed. São Paulo: Pearson, 2004. 
PINHEIRO, Fernando A. P.; SAVOIA, José Roberto F.; SECURATO, José Roberto. Basiléia III - Impacto para os Bancos no Brasil. Revista Contabilidade \& Finanças. São Paulo, v. 26, n. 69, p. 345-361, set./out./nov./dez. 2015.

POZSAR, Zoltan; ADRIAN, Tobias; ASHCRAF, Adam; BOESKY, Hayley. Shadow banking. Staff Reports $n^{\circ}$ 458, Federal Reserve Bank of New York, 2010. Available at SSRN 1640545.

ROSENBERG, Barr; REID, Kenneth; LANSTEIN, Ronald. Persuasive evidence of market inefficiency. The Journal of Portfolio Management, v. 11, n. 3, p. 9-16, 1985.

RUIZ, Cláudio; TABAK, Benjamin M.; CAJUEIRO, Daniel O. Mensuração da Eficiência Bancária no Brasil - A Inclusão de Indicadores Macroprudenciais. Revista Brasileira de Finanças, v. 6, n. 3, 2008.

SENSARMA, Rudra. Are foreign banks always the best? Comparison of state-owned, private and foreign banks in India. Economic Modelling, v. 23, n. 4, p. 717-735, 2006.

SHARPE, William F. Capital asset prices: A theory of market equilibrium under conditions of risk. The Journal of Finance, v. 19, n. 3, p. 425-442, 1964.

SHEAFFER, Zachary; RICHARDSON, Bill; ROSENBLATT, Zehava. Early-Warning Signals Management: A Lesson from the Barings Crisis. Journal of Contingencies and Crisis Management, v. 6, n. 1, p. 1-22, 1998.

SILVA, Tarcio Lopes; JORGE NETO, P. de M. Economia de escala e eficiência nos bancos brasileiros após o Plano Real. Estudos Econômicos, v. 32, n. 4, p. 577-619, 2002.

SLOVIK, Patrick; COURNÈDE, Boris. Macroeconomic impact of Basel III. Working Papers nº 844, OECD, 2011.

SOLNIK, Bruno H. An equilibrium model of the international capital market. Journal of economic theory, v. 8, n. 4, p. 500-524, 1974.

STATTMAN, Dennis. Book values and stock returns. The Chicago MBA: A journal of selected papers, v. 4, n. 1, p. 25-45, 1980.

STIGLITZ, Joseph E.; WEISS, Andrew. Credit rationing in markets with imperfect information. The American Economic Review, p. 393-410, 1981.

STOCK, James H.; WATSON, Mark W. Econometria. São Paulo, Addison Wesley, 2004.

TABAK, Benjamin M.; FAZIO, Dimas M.; CAJUEIRO, Daniel O. Profit, Cost and Scale Efficiency for Latin American Banks: concentration-performance relationship. Working n 244 , Banco Central do Brasil, 2011. 
UNITED STATES DEPARTMENT OF LABOR. Dados sobre o índice de preços ao consumidor nos Estados Unidos. Disponível em $<$ http://www.bls.gov/bls/exit_ BLS.htm?a=true\&url=http://www.dol.gov/>. Acesso em 08/11/2015.

UNITED STATES DEPARTMENT OF THE TREASURY. Dados sobre a taxa de juros dos títulos do tesouro americano. Disponível em <http://www.treasury.gov/resource-center/datachart-center/interest-rates/Pages/default.aspx>. Acesso em 08/11/2015.

VAZQUEZ, Francisco; FEDERICO, Pablo Mariano. Bank funding structures and risk: evidence from the global financial crisis. Journal of Banking \& Finance, v. 61, p. 1-14, 2015.

WOOLDRIDGE, Jeffrey M. Introdução à Econometria: uma abordagem moderna. São Paulo: Cengage Learning, 2012.

YAN, Meilan; HALL, Maximilian JB; TURNER, Paul. A cost-benefit analysis of Basel III: Some evidence from the UK. International Review of Financial Analysis, v. 25, p. 73-82, 2012 


\section{APÊNDICES}

APÊNDICE 1 - Instituições integrantes da análise e demonstrativos financeiros utilizados

APÊNDICE 2 - Instituições por cluster

APÊNDICE 3 - Cotações médias no mês das ações de bancos brasileiros

APÊNDICE 4 - Retornos mensais das ações de bancos

APÊNDICE 5 - Estimação do beta dos bancos brasileiros

APÊNDICE 6 - Estimação do beta Ibovespa / S\&P 500

APÊNDICE 7 - Regressões determinantes do ROE

APÊNDICE 8 - Teste da média condicional zero dos resíduos

APÊNDICE 9 - Modelo de base de dados para as regressões entre ROE e PL

APÊNDICE 10 - Modelo de base de dados para a estimação do beta 
APÊNDICE 1 - Instituições integrantes da análise e demonstrativos financeiros utilizados

\begin{tabular}{|c|c|c|c|c|c|c|c|c|c|c|c|c|c|}
\hline Tipologia & Instituiçãa & TCB & 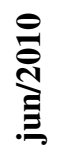 & 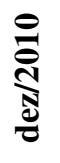 & 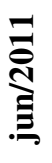 & 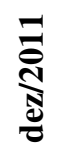 & 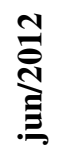 & 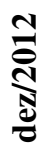 & 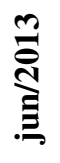 & 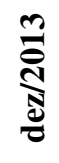 & 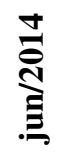 & 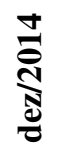 & \\
\hline \multirow{32}{*}{ 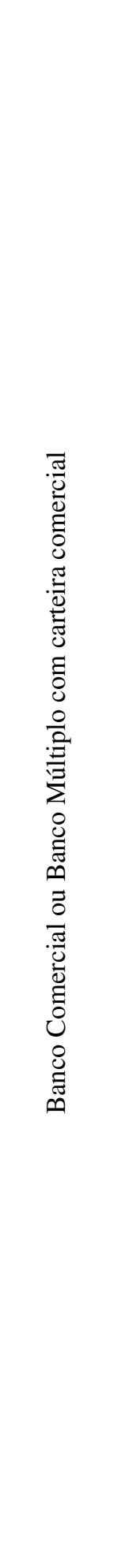 } & A J RENNER & B-I & $\bullet$ & $\bullet$ & $\bullet$ & - & $\bullet$ & • & - & $\bullet$ & $\bullet$ & $\bullet$ & 10 \\
\hline & ABC-BRASIL & B-I & - & - & - & - & - & - & - & - & - & - & 10 \\
\hline & ABN AMRO & B-I & & & & & & & & - & - & - & 3 \\
\hline & ALFA & B-I & - & - & - & - & - & - & - & - & $\bullet$ & - & 10 \\
\hline & ARBI & B-I & - & - & - & - & - & - & - & - & - & - & 10 \\
\hline & AZTECA DO BRASIL & B-I & - & - & - & $\bullet$ & • & - & - & - & - & $\bullet$ & 10 \\
\hline & BANCAP & B-I & $\bullet$ & $\bullet$ & $\bullet$ & $\bullet$ & $\bullet$ & $\bullet$ & $\bullet$ & $\bullet$ & $\bullet$ & • & 10 \\
\hline & BANCO CR2 & B-I & - & - & - & - & - & - & - & & & & 7 \\
\hline & BANCOOB & B-I & - & - & - & - & - & - & - & • & - & - & 10 \\
\hline & BANESE & B-I & $\bullet$ & $\bullet$ & $\bullet$ & $\bullet$ & $\bullet$ & • & - & $\bullet$ & $\bullet$ & $\bullet$ & 10 \\
\hline & BANESTES & B-I & - & - & $\bullet$ & $\bullet$ & • & $\bullet$ & $\bullet$ & $\bullet$ & $\bullet$ & • & 10 \\
\hline & BANIF & B-I & - & - & $\bullet$ & $\bullet$ & $\bullet$ & - & - & $\bullet$ & $\bullet$ & $\bullet$ & 10 \\
\hline & BANPARÁ & B-I & - & - & $\bullet$ & $\bullet$ & $\bullet$ & $\bullet$ & $\bullet$ & $\bullet$ & $\bullet$ & $\bullet$ & 10 \\
\hline & BANRISUL & B-I & - & - & $\bullet$ & $\bullet$ & $\bullet$ & $\bullet$ & - & - & $\bullet$ & - & 10 \\
\hline & BARCLAYS & B-I & - & $\bullet$ & $\bullet$ & $\bullet$ & $\bullet$ & $\bullet$ & $\bullet$ & $\bullet$ & $\bullet$ & $\bullet$ & 10 \\
\hline & BASA & B-I & - & - & $\bullet$ & $\bullet$ & $\bullet$ & $\bullet$ & & $\bullet$ & $\bullet$ & $\bullet$ & 9 \\
\hline & $\mathrm{BB}$ & B-I & - & - & $\bullet$ & $\bullet$ & - & - & - & $\bullet$ & $\bullet$ & $\bullet$ & 10 \\
\hline & BBM & B-I & $\bullet$ & - & • & • & $\bullet$ & $\bullet$ & $\bullet$ & $\bullet$ & • & $\cdot$ & 10 \\
\hline & BIC & B-I & $\bullet$ & - & $\bullet$ & $\bullet$ & - & - & & $\bullet$ & $\bullet$ & - & 9 \\
\hline & BM\&FBOVESPA & B-I & $\bullet$ & $\bullet$ & - & $\bullet$ & - & - & $\bullet$ & - & $\bullet$ & - & 10 \\
\hline & BMG & B-I & - & - & $\bullet$ & • & $\bullet$ & - & $\bullet$ & $\bullet$ & • & $\cdot$ & 10 \\
\hline & BNB & B-I & - & • & - & • & • & - & $\bullet$ & $\bullet$ & - & • & 10 \\
\hline & BNP PARIBAS & B-I & - & - & - & - & $\bullet$ & $\bullet$ & - & $\bullet$ & $\bullet$ & $\bullet$ & 10 \\
\hline & BNY MELLON & B-I & & & & & & • & $\bullet$ & $\bullet$ & $\bullet$ & $\cdot$ & 5 \\
\hline & BOFA MERRILL LYNCH & B-I & • & $\bullet$ & • & • & • & - & $\bullet$ & • & • & • & 10 \\
\hline & BONSUCESSO & B-I & - & $\cdot$ & - & & • & $\bullet$ & $\bullet$ & $\bullet$ & $\bullet$ & • & 9 \\
\hline & BPN BRASIL & B-I & $\bullet$ & • & $\cdot$ & • & $\cdot$ & $\bullet$ & $\cdot$ & $\bullet$ & $\cdot$ & $\cdot$ & 10 \\
\hline & BRACCE & B-I & • & $\bullet$ & $\bullet$ & $\bullet$ & $\bullet$ & $\bullet$ & $\bullet$ & • & • & $\bullet$ & 10 \\
\hline & BRADESCO & B-I & - & - & • & - & • & • & $\bullet$ & • & $\bullet$ & • & 10 \\
\hline & BRASIL PLURAL & B-I & & & & & & - & - & - & $\bullet$ & $\cdot$ & 5 \\
\hline & BRB & B-I & • & • & $\bullet$ & • & $\bullet$ & $\bullet$ & $\bullet$ & • & $\bullet$ & • & 10 \\
\hline & BTG PACTUAL & B-I & - & - & • & - & - & - & - & - & - & - & 10 \\
\hline
\end{tabular}




\begin{tabular}{|c|c|c|c|c|c|c|c|c|c|c|c|c|c|}
\hline Tipologia & Instituiçãa & TCB & 尽 & 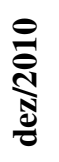 & 司 & 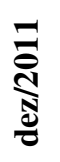 & 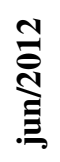 & 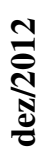 & 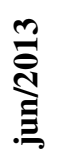 & 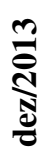 & 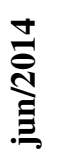 & 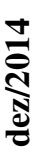 & $\frac{\bar{\sigma}}{\theta}$ \\
\hline \multirow{35}{*}{ 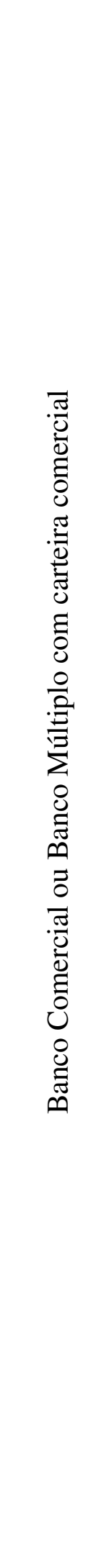 } & BVA & B-I & - & - & - & • & - & & & & & & 5 \\
\hline & CAIXA ECONOMICA FEDERAL & B-I & - & - & - & - & - & - & - & - & - & - & 10 \\
\hline & CAIXA GERAL BRASIL & B-I & • & & - & - & - & & - & • & • & - & 8 \\
\hline & CARGILL & B-I & - & - & - & • & - & - & • & - & • & - & 10 \\
\hline & CEDULA & B-I & - & - & - & • & - & • & • & - & • & - & 10 \\
\hline & CITIBANK & B-I & • & - & - & - & - & • & • & - & • & - & 10 \\
\hline & CLASSICO & B-I & • & - & - & - & - & - & - & • & - & - & 10 \\
\hline & CONCÓRDIA & B-I & - & & & & & & & & & & 1 \\
\hline & CREDIBEL & B-I & - & - & - & & & & & & & & 3 \\
\hline & CREDIT AGRICOLE & B-I & - & - & - & - & - & - & - & - & - & - & 10 \\
\hline & CREDIT SUISSE & B-I & - & - & - & - & - & - & - & - & - & - & 10 \\
\hline & CRUZEIRO DO SUL & B-I & $\bullet$ & - & - & - & & & & & & & 4 \\
\hline & DAYCOVAL & B-I & - & - & - & - & - & - & - & - & - & - & 10 \\
\hline & DBB BM & B-I & $\bullet$ & - & - & & & & & & & & 3 \\
\hline & DEUTSCHE BANK & B-I & - & - & - & - & - & - & - & - & - & - & 10 \\
\hline & FATOR & B-I & - & - & - & - & - & - & - & - & - & - & 10 \\
\hline & FIBRA & B-I & & - & - & - & - & - & - & - & - & - & 9 \\
\hline & FICSA & B-I & - & - & & - & - & - & - & - & - & - & 9 \\
\hline & GE CAPITAL & B-I & & - & & & & & & & & & 1 \\
\hline & GERADOR & B-I & - & - & - & - & - & - & - & - & - & - & 10 \\
\hline & GUANABARA & B-I & - & - & - & - & - & - & - & - & - & - & 10 \\
\hline & HSBC & B-I & - & - & - & - & - & - & - & - & - & - & 10 \\
\hline & ICBC DO BRASIL BM & B-I & & & & & & & & - & - & - & 3 \\
\hline & INDUSTRIAL DO BRASIL & B-I & • & - & $\bullet$ & - & - & • & - & - & - & • & 10 \\
\hline & INDUSVAL & B-I & • & $\bullet$ & $\bullet$ & $\bullet$ & • & $\bullet$ & $\bullet$ & - & $\bullet$ & $\bullet$ & 10 \\
\hline & ING & B-I & - & - & - & - & - & - & - & - & - & - & 10 \\
\hline & INTERCAP & B-I & - & - & - & - & - & - & - & & & & 7 \\
\hline & INTERMEDIUM & B-I & - & - & - & - & - & - & - & - & - & - & 10 \\
\hline & ITAU UNIBANCO & B-I & • & - & - & - & - & - & - & - & - & - & 10 \\
\hline & JBS BANCO & B-I & - & - & - & & & & & & & & 3 \\
\hline & JOHN DEERE & B-I & - & - & - & - & - & - & - & - & - & - & 10 \\
\hline & JP MORGAN CHASE & B-I & - & - & - & - & - & - & - & - & - & - & 10 \\
\hline & KDB BRASIL & B-I & - & - & - & - & - & - & & & - & - & 8 \\
\hline & KEB DO BRASIL & B-I & - & - & - & - & - & - & - & - & - & - & 10 \\
\hline & LA NACION ARGENTINA & B-I & - & - & - & - & - & - & - & - & - & - & 10 \\
\hline
\end{tabular}




\begin{tabular}{|c|c|c|c|c|c|c|c|c|c|c|c|c|c|}
\hline Tipologia & Instituiçãa & TCB & 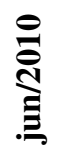 & 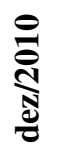 & 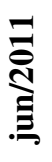 & 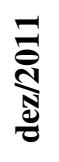 & 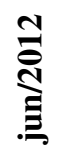 & 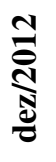 & 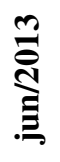 & 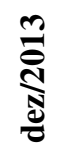 & 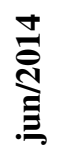 & 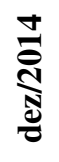 & స్ \\
\hline \multirow{35}{*}{ 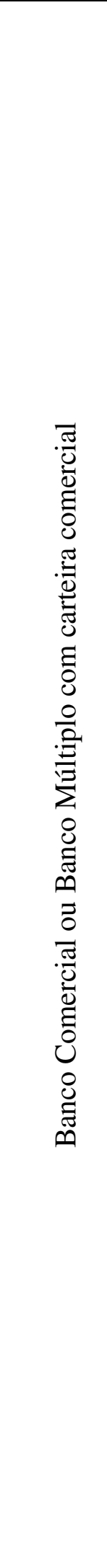 } & LA PROVINCIA B AIRES & B-I & - & - & - & - & - & - & - & - & & - & 9 \\
\hline & LUSO BRASILEIRO & B-I & - & - & & - & - & - & - & - & - & - & 9 \\
\hline & MATONE & B-I & - & - & - & & & & & & & & 3 \\
\hline & MÁXIMA & B-I & - & • & - & • & • & - & & - & - & - & 9 \\
\hline & MERCANTIL DO BRASIL & B-I & - & - & - & - & - & - & - & - & - & - & 10 \\
\hline & MIZUHO & B-I & & & & & & & & • & - & - & 3 \\
\hline & MODAL & B-I & - & - & - & - & - & - & - & - & - & - & 10 \\
\hline & MORADA & B-I & - & - & & & & & & & & & 2 \\
\hline & MORGAN STANLEY & B-I & - & - & - & - & - & - & - & - & - & - & 10 \\
\hline & NATIXIS BRASIL BM & B-I & $\bullet$ & - & - & - & - & - & - & - & - & - & 10 \\
\hline & NBC BANK BRASIL BM & B-I & $\bullet$ & $\bullet$ & $\bullet$ & $\bullet$ & $\bullet$ & • & - & $\bullet$ & $\bullet$ & $\bullet$ & 10 \\
\hline & ORIGINAL & B-I & & & & $\bullet$ & $\bullet$ & • & $\bullet$ & $\bullet$ & $\bullet$ & $\bullet$ & 7 \\
\hline & PANAMERICANO & B-I & $\bullet$ & - & $\bullet$ & $\bullet$ & $\bullet$ & • & $\bullet$ & $\bullet$ & $\bullet$ & $\bullet$ & 10 \\
\hline & PARANÁ BANCO & B-I & - & - & - & - & - & - & - & - & - & - & 10 \\
\hline & PETRA & B-I & $\bullet$ & $\bullet$ & $\bullet$ & • & • & - & $\bullet$ & $\bullet$ & • & $\bullet$ & 10 \\
\hline & PINE & B-I & - & & - & - & - & - & - & - & - & - & 9 \\
\hline & POTTENCIAL & B-I & $\bullet$ & - & $\bullet$ & $\bullet$ & $\bullet$ & $\bullet$ & $\bullet$ & • & $\bullet$ & $\bullet$ & 10 \\
\hline & PROSPER & B-I & • & • & $\bullet$ & - & & & & & & & 4 \\
\hline & RABOBANK & B-I & $\bullet$ & • & $\bullet$ & • & $\bullet$ & - & • & • & $\bullet$ & • & 10 \\
\hline & RANDON & B-I & & - & - & - & - & - & - & - & - & - & 9 \\
\hline & RENDIMENTO & B-I & - & - & - & • & - & • & $\bullet$ & • & $\bullet$ & • & 10 \\
\hline & REP ORIENTAL URUGUAY & B-I & • & • & $\bullet$ & • & • & • & • & $\bullet$ & $\bullet$ & $\bullet$ & 10 \\
\hline & RIBEIRAO PRETO & B-I & $\bullet$ & $\bullet$ & $\bullet$ & $\bullet$ & $\bullet$ & - & - & - & - & - & 10 \\
\hline & RODOBENS & B-I & • & $\bullet$ & $\bullet$ & • & - & $\bullet$ & • & $\bullet$ & $\bullet$ & & 9 \\
\hline & RURAL & B-I & $\bullet$ & • & • & & & $\bullet$ & & & & & 4 \\
\hline & SAFRA & B-I & • & $\bullet$ & - & $\bullet$ & • & - & $\bullet$ & $\bullet$ & $\bullet$ & • & 10 \\
\hline & SANTANDER & B-I & - & $\bullet$ & • & $\bullet$ & $\bullet$ & • & $\bullet$ & $\bullet$ & $\bullet$ & $\bullet$ & 10 \\
\hline & SCHAHIN & B-I & & - & & & & & & & & & 1 \\
\hline & SCOTIABANK BRASIL & B-I & & & & • & $\bullet$ & • & • & $\bullet$ & $\bullet$ & • & 7 \\
\hline & SEMEAR & B-I & - & $\bullet$ & $\bullet$ & • & $\bullet$ & • & - & $\bullet$ & $\bullet$ & $\bullet$ & 10 \\
\hline & SICREDI & B-I & - & • & • & $\bullet$ & • & $\bullet$ & $\bullet$ & $\bullet$ & $\bullet$ & $\bullet$ & 10 \\
\hline & SOCIETE GENERALE & B-I & - & - & - & - & - & - & - & • & - & - & 10 \\
\hline & SOCOPA & B-I & - & - & - & • & $\bullet$ & - & - & - & - & • & 10 \\
\hline & SOFISA & B-I & $\bullet$ & $\bullet$ & • & $\bullet$ & • & • & • & & • & • & 9 \\
\hline & SUMITOMO MITSUI & B-I & - & • & - & - & • & - & - & - & - & - & 10 \\
\hline
\end{tabular}




\begin{tabular}{|c|c|c|c|c|c|c|c|c|c|c|c|c|c|}
\hline Tipologia & Instituição & TCB & 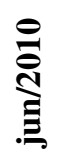 & 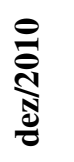 & $\stackrel{\Xi}{\stackrel{\Xi}{\Xi}}$ & 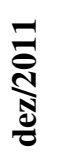 & 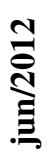 & 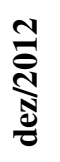 & 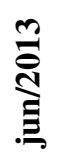 & 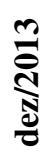 & $\underset{\Xi}{\stackrel{\Xi}{\Xi}}$ & & 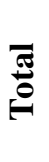 \\
\hline & TOKYO-MITSUBISHI & B-I & - & - & - & - & - & - & - & - & - & - & 10 \\
\hline & TOPÁZIO & B-I & - & - & - & - & - & - & - & - & - & - & 10 \\
\hline & TRIANGULO & B-I & - & - & - & - & - & - & - & - & - & - & 10 \\
\hline & VOTORANTIM & B-I & • & - & • & - & • & - & - & - & - & - & 10 \\
\hline & VR & B-I & - & • & • & - & • & - & - & • & - & - & 10 \\
\hline & WESTERN UNION & B-I & & & & - & - & - & - & - & - & - & 7 \\
\hline & WESTLB & B-I & - & - & - & - & - & • & • & & & & 7 \\
\hline & WOORI BANK DO BRASIL & B-I & & & & & & - & - & • & - & - & 5 \\
\hline & BANCO DA CHINA BRASIL & B-I & - & - & - & - & - & - & - & - & - & - & 10 \\
\hline \multirow{26}{*}{ 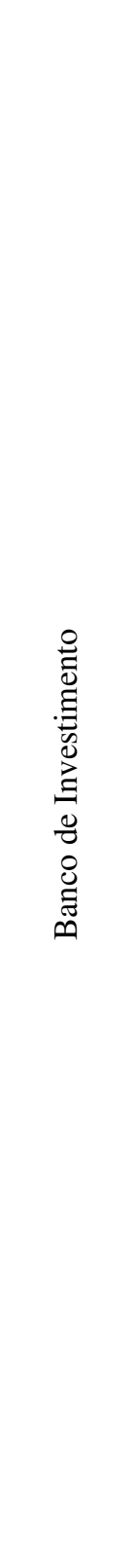 } & BBVA BRASIL BI & B-II & - & - & - & - & - & - & - & - & - & - & 10 \\
\hline & BES & B-II & - & - & - & - & - & - & - & - & - & - & 10 \\
\hline & BR PARTNERS & B-II & & & & & & - & - & - & - & - & 5 \\
\hline & BRJ & B-II & - & - & - & - & - & • & - & - & & - & 9 \\
\hline & CATERPILLAR & B-II & & & • & • & - & - & • & & - & • & 7 \\
\hline & CNH CAPITAL & B-II & - & - & - & - & - & - & - & - & - & - & 10 \\
\hline & $\mathrm{CSF}$ & B-II & - & - & - & - & - & - & - & - & - & - & 10 \\
\hline & FIDIS & B-II & - & - & - & - & - & - & - & - & - & - & 10 \\
\hline & FORD & B-II & - & - & - & - & - & - & - & - & - & - & 10 \\
\hline & GERAÇÃO FUTURO & B-II & - & - & - & - & - & - & & & & & 6 \\
\hline & GOLDMAN SACHS & B-II & - & - & - & - & - & - & - & - & - & - & 10 \\
\hline & HONDA & B-II & - & - & - & - & - & - & - & - & - & - & 10 \\
\hline & IBM & B-II & - & - & - & - & - & - & - & - & - & - & 10 \\
\hline & INDUSCRED & B-II & - & - & - & - & - & - & - & - & - & - & 10 \\
\hline & LAGE LANDEN & B-II & - & - & - & - & - & - & - & - & - & - & 10 \\
\hline & MAXINVEST & B-II & - & - & - & - & - & - & - & - & - & - & 10 \\
\hline & MERCEDES-BENZ & B-II & - & - & - & - & - & - & - & - & - & - & 10 \\
\hline & MONEO & B-II & - & - & - & - & - & - & - & - & • & - & 10 \\
\hline & OPPORTUNITY & B-II & - & - & • & - & • & - & - & • & - & - & 10 \\
\hline & OURINVEST & B-II & $\bullet$ & - & - & - & - & - & - & - & - & - & 10 \\
\hline & PORTO REAL DE INVEST & B-II & • & - & - & - & - & - & - & - & - & - & 10 \\
\hline & PSA FINANCE & B-II & - & - & - & - & - & - & - & - & - & - & 10 \\
\hline & SCANIA & B-II & - & - & - & - & - & - & & - & - & - & 9 \\
\hline & STANDARD CHARTERED BI & B-II & - & - & - & - & - & & - & - & - & - & 9 \\
\hline & STANDARD INVESTIMENTOS BI & B-II & & & • & - & - & - & - & • & - & - & 8 \\
\hline & TOYOTA DO BRASIL & B-II & • & • & - & - & - & - & & • & - & - & 9 \\
\hline
\end{tabular}




\begin{tabular}{|c|c|c|c|c|c|c|c|c|c|c|c|c|}
\hline Tipologia & Instituição & TCB & 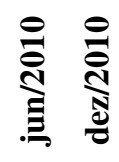 & 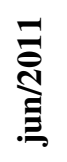 & تב & 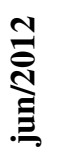 & 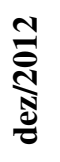 & 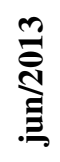 & 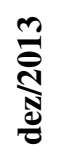 & $\underset{\Xi}{\stackrel{\Xi}{\Xi}}$ & 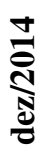 & อั \\
\hline \multirow{9}{*}{ 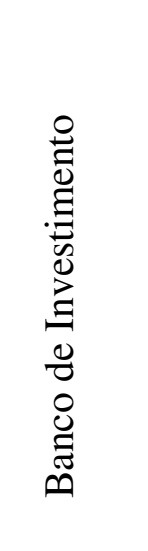 } & TRICURY & B-II & - & • & $\bullet$ & • & - & $\bullet$ & - & $\bullet$ & - & 10 \\
\hline & UBS & B-II & & & & & & & • & - & - & 3 \\
\hline & VIPAL & B-II & & - & $\bullet$ & - & - & $\bullet$ & - & - & - & 8 \\
\hline & VOLKSWAGEN & B-II & - & - & - & - & - & - & - & - & - & 10 \\
\hline & VOLVO & B-II & - & • & • & - & - & - & - & - & - & 10 \\
\hline & YAMAHA MOTOR & B-II & $\bullet$ & - & $\bullet$ & $\bullet$ & • & $\bullet$ & • & $\bullet$ & - & 10 \\
\hline & GMAC & B-II & $\bullet$ & - & • & - & - & $\bullet$ & - & $\bullet$ & • & 10 \\
\hline & CIT BRASIL & B-II & $\cdot$ & - & • & - & $\bullet$ & $\bullet$ & • & - & $\bullet$ & 10 \\
\hline & PORTO SEGURO & B-II & - & $\bullet$ & $\bullet$ & & & & & & & 4 \\
\hline \multirow{4}{*}{ 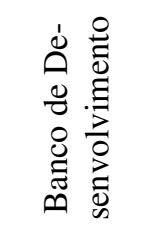 } & BANDES & B-IV & • & - & $\bullet$ & - & $\bullet$ & $\bullet$ & - & $\bullet$ & - & 10 \\
\hline & BDMG & B-IV & $\bullet$ & $\bullet$ & $\bullet$ & - & $\bullet$ & $\bullet$ & $\bullet$ & $\bullet$ & $\bullet$ & 10 \\
\hline & BNDES & B-IV & • & $\bullet$ & $\bullet$ & $\bullet$ & $\bullet$ & $\bullet$ & $\bullet$ & $\bullet$ & - & 10 \\
\hline & BRDE & B-IV & - & • & • & $\bullet$ & $\bullet$ & $\bullet$ & $\bullet$ & • & • & 10 \\
\hline \multirow{3}{*}{ 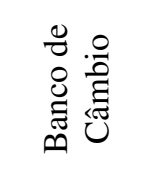 } & BEXS & B-II & & & - & - & - & $\bullet$ & - & $\bullet$ & - & 7 \\
\hline & CONFIDENCE & B-II & & & • & & $\bullet$ & $\bullet$ & $\bullet$ & $\bullet$ & - & 6 \\
\hline & MSB BANK & B-II & & & & & & & & $\bullet$ & - & 2 \\
\hline \multirow{19}{*}{ 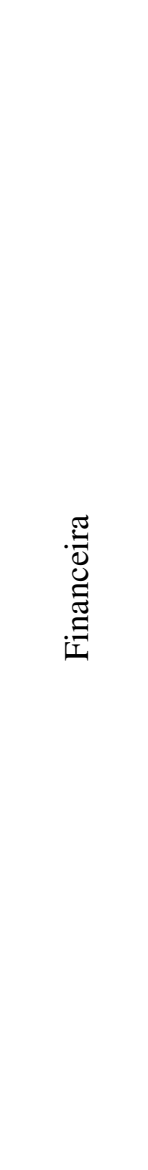 } & AGIPLAN FINANCEIRA CFI & $\mathrm{N}$ & & - & $\bullet$ & - & $\bullet$ & $\bullet$ & $\bullet$ & $\bullet$ & $\bullet$ & 8 \\
\hline & AGORACRED SCFI & $\mathrm{N}$ & & & & & & & - & - & - & 3 \\
\hline & ATRIA CFI & $\mathrm{N}$ & & • & - & • & $\bullet$ & & • & $\bullet$ & - & 7 \\
\hline & BANEX CFI & $\mathrm{N}$ & & $\bullet$ & $\bullet$ & & & & & & & 2 \\
\hline & BARIGUI CFI & $\mathrm{N}$ & & $\bullet$ & & • & $\bullet$ & $\bullet$ & • & $\bullet$ & $\bullet$ & 7 \\
\hline & BIORC FINANCEIRA CFI & $\mathrm{N}$ & & - & - & $\bullet$ & - & • & • & $\bullet$ & • & 8 \\
\hline & BONCRED & $\mathrm{N}$ & & • & - & • & $\bullet$ & - & & $\bullet$ & $\bullet$ & 7 \\
\hline & BRICKELL CFI & $\mathrm{N}$ & & $\bullet$ & - & - & - & - & $\bullet$ & - & $\bullet$ & 8 \\
\hline & CARUANA SCFI & $\mathrm{N}$ & & - & - & $\bullet$ & - & • & • & $\bullet$ & • & 8 \\
\hline & CIFRA CFI & $\mathrm{N}$ & & & $\bullet$ & & & & & & & 1 \\
\hline & CREDIFIBRA CFI & $\mathrm{N}$ & & & $\bullet$ & $\bullet$ & & & & & & 2 \\
\hline & CREDITÁ CFI & $\mathrm{N}$ & & • & - & $\bullet$ & • & • & $\bullet$ & • & $\bullet$ & 8 \\
\hline & CREDITEC SCFI & $\mathrm{N}$ & & & • & • & & & & & & 2 \\
\hline & CREFISA CFI & $\mathrm{N}$ & & - & • & • & - & - & - & - & - & 8 \\
\hline & DACASA FINANCEIRA & $\mathrm{N}$ & & & & & & & - & - & - & 3 \\
\hline & DACASA FINANCEIRA SCFI & $\mathrm{N}$ & & & & - & - & - & & & & 3 \\
\hline & DIRECAO CFI & $\mathrm{N}$ & & $\bullet$ & • & $\bullet$ & $\bullet$ & $\bullet$ & - & - & $\bullet$ & 8 \\
\hline & DREBES FINANCEIRA CFI & $\mathrm{N}$ & & - & • & • & $\bullet$ & $\cdot$ & - & $\cdot$ & - & 8 \\
\hline & FACTA CFI & $\mathrm{N}$ & & & & & - & & - & - & - & 4 \\
\hline
\end{tabular}




\begin{tabular}{|c|c|c|c|c|c|c|c|c|c|c|c|c|}
\hline Tipologia & Instituiçãa & TCB & 을 & $\stackrel{\Xi}{\stackrel{\Xi}{\Xi}}$ & 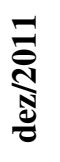 & 瓷 & 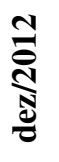 & 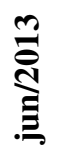 & 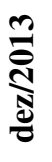 & 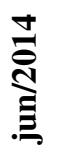 & 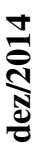 & స్ \\
\hline \multirow{28}{*}{ 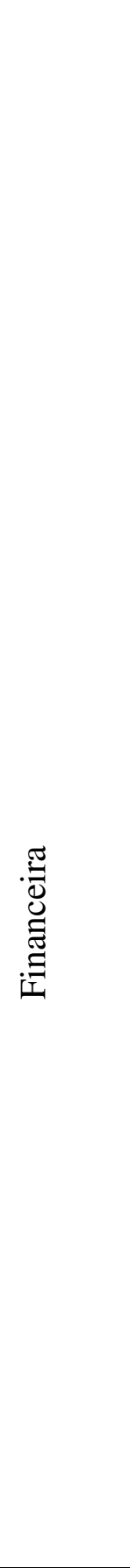 } & FINAMAX CFI & $\mathrm{N}$ & & - & - & - & - & - & - & - & - & 8 \\
\hline & FINANSINOS CFI & $\mathrm{N}$ & & - & - & - & - & - & - & - & - & 8 \\
\hline & GAZINCRED SCFI & $\mathrm{N}$ & & - & - & - & - & - & - & - & - & 8 \\
\hline & GOLCRED CFI & $\mathrm{N}$ & & - & • & • & - & • & - & • & - & 8 \\
\hline & $\begin{array}{l}\text { GRAZZIOTIN FINANCIADORA } \\
\text { CFI }\end{array}$ & $\mathrm{N}$ & & - & $\cdot$ & $\bullet$ & $\bullet$ & $\cdot$ & $\bullet$ & $\bullet$ & $\bullet$ & 8 \\
\hline & GUILTON CFI & $\mathrm{N}$ & & - & - & - & - & - & - & - & - & 8 \\
\hline & HERVAL FINANCEIRA CFI & $\mathrm{N}$ & & - & - & - & - & • & - & • & - & 8 \\
\hline & KREDILIG CFI & $\mathrm{N}$ & & - & - & - & • & - & - & - & - & 8 \\
\hline & LECCA CFI & $\mathrm{N}$ & & - & • & - & - & • & - & • & - & 8 \\
\hline & MIDWAY SCFI & $\mathrm{N}$ & & - & - & - & - & - & - & - & - & 8 \\
\hline & MÚLTIPLA CFI & $\mathrm{N}$ & & - & - & - & - & - & - & - & - & 8 \\
\hline & NEGRESCO CFI & $\mathrm{N}$ & & - & - & - & - & - & - & - & - & 8 \\
\hline & OMNI CFI & $\mathrm{N}$ & & - & - & - & - & - & - & - & - & 8 \\
\hline & PARATI CFI & $\mathrm{N}$ & & - & - & - & - & - & - & - & - & 8 \\
\hline & PERNAMBUCANAS CFI & $\mathrm{N}$ & & $\bullet$ & • & $\bullet$ & $\bullet$ & $\bullet$ & • & • & $\bullet$ & 8 \\
\hline & PORTO SEGURO CFI & $\mathrm{N}$ & & $\bullet$ & • & $\bullet$ & $\bullet$ & $\bullet$ & • & • & $\bullet$ & 8 \\
\hline & PORTOCRED CFI & $\mathrm{N}$ & & $\bullet$ & $\bullet$ & $\bullet$ & $\bullet$ & $\bullet$ & $\bullet$ & $\bullet$ & - & 8 \\
\hline & QUERO-QUERO CFI & $\mathrm{N}$ & & - & - & - & - & & & & & 4 \\
\hline & ROTULA SCFI & $\mathrm{N}$ & & - & & & & & & & & 1 \\
\hline & SANTANA CFI & $\mathrm{N}$ & & - & - & - & - & - & - & - & - & 8 \\
\hline & SANTINVEST CFI & $\mathrm{N}$ & & - & - & - & - & - & - & - & - & 8 \\
\hline & SAX CFI & $\mathrm{N}$ & & - & - & - & - & - & - & - & - & 8 \\
\hline & SENFF CFI & $\mathrm{N}$ & & - & - & - & - & - & - & - & - & 8 \\
\hline & SOCINAL CFI & $\mathrm{N}$ & & - & - & - & & & - & - & - & 6 \\
\hline & SOROCRED CFI & $\mathrm{N}$ & & - & - & - & - & - & - & - & - & 8 \\
\hline & STARA FINANCEIRA CFI & $\mathrm{N}$ & & & & & & • & - & • & - & 4 \\
\hline & TODESCREDI CFI & $\mathrm{N}$ & & • & - & - & • & - & - & - & • & 8 \\
\hline & VIA CERTA FINANCIADORA CFI & $\mathrm{N}$ & & & & & & - & - & - & - & 4 \\
\hline \multirow{7}{*}{ 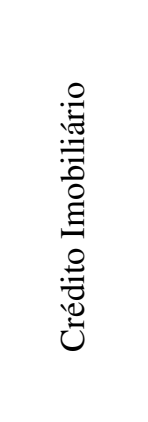 } & APEAL CI & $\mathrm{N}$ & & - & - & - & - & - & - & - & - & 8 \\
\hline & APEMAT CI & $\mathrm{N}$ & & $\bullet$ & $\bullet$ & $\bullet$ & • & - & $\bullet$ & & & 6 \\
\hline & CIA PROVINCIA CI & $\mathrm{N}$ & & - & - & - & - & - & - & & & 6 \\
\hline & COMPANHIA PROVINCIA CI & $\mathrm{N}$ & & & & & & & & - & - & 2 \\
\hline & ECONOMISA CI & $\mathrm{N}$ & & - & - & - & - & - & - & - & - & 8 \\
\hline & FAMILIA PAULISTA CI & $\mathrm{N}$ & & • & • & - & - & • & • & • & - & 8 \\
\hline & FIN-HAB CI & $\mathrm{N}$ & & - & - & & & & & & & 2 \\
\hline
\end{tabular}




\begin{tabular}{|c|c|c|c|c|c|c|c|c|c|c|c|c|}
\hline Tipologia & Instituição & TCB & 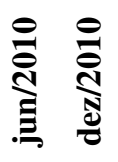 & $\stackrel{\Xi}{\stackrel{\Xi}{\Xi}}$ & 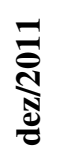 & ฏ & 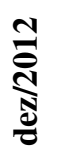 & 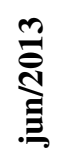 & 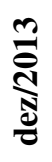 & $\underset{\Xi}{\stackrel{\Xi}{\Xi}}$ & 离 & อี \\
\hline & HABITASUL CI & $\mathrm{N}$ & & $\bullet$ & - & - & $\bullet$ & $\bullet$ & - & $\bullet$ & & 7 \\
\hline & LARCKY SCI & $\mathrm{N}$ & & - & - & - & & - & - & - & • & 7 \\
\hline & MUTUAL APETRIM CI & $\mathrm{N}$ & & - & $\bullet$ & - & $\bullet$ & $\bullet$ & & $\bullet$ & & 6 \\
\hline & TERRA CIA DE CI & $\mathrm{N}$ & & • & • & - & & & & & & 3 \\
\hline & TRADICAO CI & $\mathrm{N}$ & & • & - & $\bullet$ & $\bullet$ & $\bullet$ & $\bullet$ & $\bullet$ & • & 8 \\
\hline \multirow{5}{*}{ 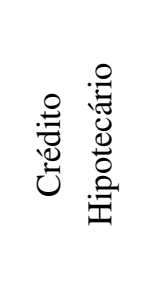 } & BRAZILIAN MORTGAGES CH & $\mathrm{N}$ & & - & $\bullet$ & & & & & & & 2 \\
\hline & CH PIRATINI - CHP & $\mathrm{N}$ & & & & & & & - & & & 1 \\
\hline & CHB - CIA HIPOT. BRASILEIRA & $\mathrm{N}$ & & $\bullet$ & $\bullet$ & $\bullet$ & $\bullet$ & $\bullet$ & $\bullet$ & $\bullet$ & • & 8 \\
\hline & COBANSA CH & $\mathrm{N}$ & & - & - & - & - & - & - & - & - & 8 \\
\hline & DOMUS CH & $\mathrm{N}$ & & - & - & - & - & - & - & - & - & 8 \\
\hline \multirow{6}{*}{ 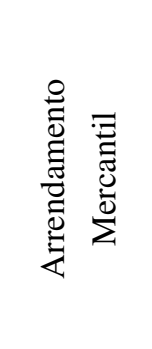 } & BMW AM & $\mathrm{N}$ & & $\bullet$ & $\bullet$ & $\bullet$ & $\bullet$ & $\bullet$ & $\bullet$ & • & • & 8 \\
\hline & CHG-MERIDIAN DO BRASIL AM & $\mathrm{N}$ & & & & & & & $\bullet$ & $\bullet$ & • & 3 \\
\hline & CSILATINA AM & $\mathrm{N}$ & & - & - & - & - & & - & - & - & 7 \\
\hline & HP FINANCIAL SERVICES AM & $\mathrm{N}$ & & $\bullet$ & $\bullet$ & $\bullet$ & $\bullet$ & $\bullet$ & $\bullet$ & • & $\bullet$ & 8 \\
\hline & JSL AM & $\mathrm{N}$ & & & & & & & & & $\bullet$ & 1 \\
\hline & LEASEPLAN AM & $\mathrm{N}$ & & - & - & - & - & - & - & - & - & 8 \\
\hline
\end{tabular}




\section{APÊNDICE 2 - Instituições por cluster}

\begin{tabular}{|c|c|c|c|c|}
\hline \multirow{2}{*}{ Tipologia } & \multirow{2}{*}{$\begin{array}{c}\text { Cluster } \\
1\end{array}$} & \multicolumn{3}{|c|}{ Instituiçãa } \\
\hline & & Petra & Bracce & \\
\hline \multirow{33}{*}{$\begin{array}{l}\text { Banco } \\
\text { comercial ou } \\
\text { banco múltiplo } \\
\text { com carteira } \\
\text { comercial }\end{array}$} & & Azteca Do Brasil & Topázio & BPN Brasil \\
\hline & 0 & Arbi & La Nacion Argentina & Máxima \\
\hline & 2 & Ficsa & Pottencial & Rep Oriental Uruguay \\
\hline & & Bancap & Gerador & \\
\hline & & Ribeirão Preto & A J Renner & Guanabara \\
\hline & & Cédula & KEB do Brasil & Socopa \\
\hline & & NBC Bank Brasil BM & Luso Brasileiro & Banco Da China Brasil \\
\hline & 3 & Woori Bank do Brasil & VR & ICBC Do Brasil BM \\
\hline & 3 & Randon & La Provincia B Aires & Banif \\
\hline & & Semear & Brasil Plural & Rendimento \\
\hline & & KDB Brasil & Natixis Brasil BM & Modal \\
\hline & & Western Union & BNY Mellon & \\
\hline & & BANESE & Industrial do Brasil & John Deere \\
\hline & & Intermedium & Mizuho & Mercantil Do Brasil \\
\hline & & Caixa Geral Brasil & ABN Amro & Sumitomo Mitsui \\
\hline & 4 & Triangulo & BANPARÁ & Credit Agricole \\
\hline & 4 & Bonsucesso & Barclays & Bancoob \\
\hline & & Fator & BBM & ING \\
\hline & & Scotiabank Brasil & Sofisa & \\
\hline & & Cargill & Indusval & \\
\hline & & Fibra & Rabobank & ABC-Brasil \\
\hline & & Societe Generale & Bofa Merrill Lynch & Daycoval \\
\hline & & BANESTES & Paraná Banco & BNP Paribas \\
\hline & 5 & Sicredi & Deutsche Bank & $\mathrm{BNB}$ \\
\hline & 3 & BRB & Basa & Credit Suisse \\
\hline & & Tokyo-Mitsubishi & Morgan Stanley & $\mathrm{BMG}$ \\
\hline & & BIC & Original & Panamericano \\
\hline & & Pine & Alfa & JP Morgan Chase \\
\hline & & Clássico & Votorantim & BTG Pactual \\
\hline & 6 & Banrisul & Safra & Caixa Econômica Federal \\
\hline & & Citibank & HSBC & \\
\hline & 7 & Santander & Bradesco & \\
\hline & 1 & $\mathrm{BB}$ & Itaú Unibanco & \\
\hline
\end{tabular}


$\begin{array}{lll}\text { Tipologia } & \text { Cluster } & \text { Instituição }\end{array}$

\begin{tabular}{|c|c|c|c|c|}
\hline \multirow{12}{*}{$\begin{array}{l}\text { Banco de } \\
\text { Investimento } \\
\text { ou banco } \\
\text { múltiplo com } \\
\text { carteira de } \\
\text { investimento }\end{array}$} & \multirow{2}{*}{2} & Induscred & Maxinvest & BRJ \\
\hline & & Porto Real De Invest & Vipal & Ourinvest \\
\hline & \multirow{4}{*}{3} & Yamaha Motor & Br Partners & Tricury \\
\hline & & UBS & Moneo & Ford \\
\hline & & BBVA Brasil Bi & Opportunity & \\
\hline & & Standard Investimentos BI & Scania & \\
\hline & \multirow{4}{*}{4} & Cit Brasil & Fidis & Volvo \\
\hline & & Standard Chartered BI & Honda & PSA Finance \\
\hline & & IBM & Caterpillar & Lage Landen \\
\hline & & Toyota Do Brasil & BES & \\
\hline & \multirow{2}{*}{5} & $\mathrm{CSF}$ & CNH Capital & GMAC \\
\hline & & Goldman Sachs & Mercedes-Benz & Volkswagen \\
\hline \multirow{14}{*}{ Financeira } & \multirow{4}{*}{1} & Biorc Financeira CFI & Golcred CFI & Parati CFI \\
\hline & & Facta CFI & Agoracred SCFI & Todescredi CFI \\
\hline & & Múltipla CFI & Creditá CFI & Boncred \\
\hline & & Senff CFI & Socinal CFI & Atria CFI \\
\hline & \multirow{6}{*}{2} & Lecca CFI & Drebes Financeira CFI & Finamax CFI \\
\hline & & Grazziotin Financiadora CFI & Stara Financeira CFI & Sorocred CFI \\
\hline & & Finansinos CFI & Brickell CFI & Caruana SCFI \\
\hline & & Gazincred SCFI & Santana CFI & Sax CFI \\
\hline & & Via Certa Financiadora CFI & Barigui CFI & Herval Financeira CFI \\
\hline & & Portocred CFI & Negresco CFI & \\
\hline & \multirow{2}{*}{3} & Kredilig CFI & Agiplan Financeira CFI & Santinvest CFI \\
\hline & & Direção CFI & Dacasa Financeira & Omni CFI \\
\hline & 4 & Porto Seguro CFI & Pernambucanas CFI & Midway SCFI \\
\hline & 5 & Crefisa CFI & & \\
\hline \multirow{4}{*}{$\begin{array}{l}\text { Crédito } \\
\text { Imobiliário }\end{array}$} & \multirow{2}{*}{1} & Cobansa $\mathrm{CH}$ & Familia Paulista CI & \\
\hline & & Tradicao CI & Cia Provincia CI & \\
\hline & \multirow{2}{*}{2} & Larcky SCI & CHB - Cia Hipot. Brasileira & \\
\hline & & Domus $\mathrm{CH}$ & Economisa CI & \\
\hline
\end{tabular}


APÊNDICE 3 - Cotações médias no mês das ações de bancos brasileiros

\begin{tabular}{|c|c|c|c|c|c|c|c|c|c|c|c|c|c|c|c|}
\hline$\stackrel{\leftrightarrow}{\Sigma}^{\infty}$ & 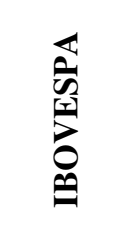 & 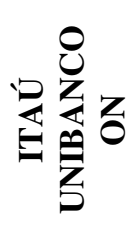 & 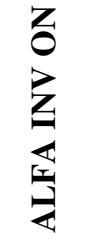 & 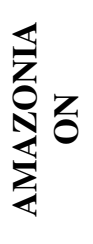 & 学 & 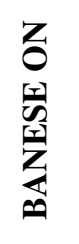 & 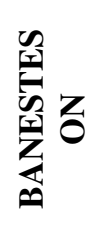 & 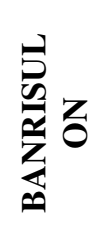 & 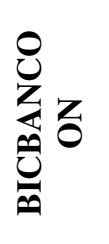 & 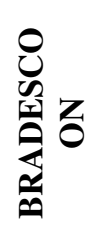 & 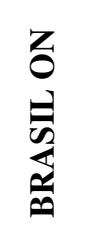 & 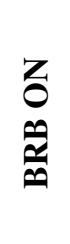 & 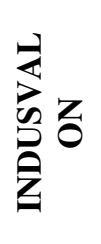 & 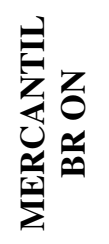 & 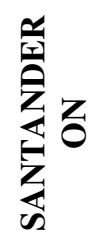 \\
\hline jan-95 & 3875,31 & 0,24 & 0,23 & 0,00 & & & & & & 0,37 & 1,40 & & & & \\
\hline fev-95 & 3340,17 & 0,25 & 0,21 & 0,00 & & & & & & 0,35 & 1,18 & & & & \\
\hline mar-95 & 2941,57 & 0,25 & 0,22 & 0,00 & & & & 5,29 & & 0,34 & 1,08 & & & & \\
\hline abr-95 & 3324,86 & 0,26 & 0,22 & 0,01 & & & & 4,95 & & 0,35 & 1,04 & & & & \\
\hline mai-95 & 3952,25 & 0,29 & 0,29 & 0,00 & & & & 5,14 & & 0,41 & 1,19 & & & & \\
\hline jun-95 & 3723,51 & 0,33 & 0,35 & 0,00 & & & & 4,66 & & 0,42 & 1,08 & & & & \\
\hline jul-95 & 3883,80 & 0,32 & 0,34 & 0,00 & & & 2,85 & 4,53 & & 0,47 & 1,31 & & & & \\
\hline ago-95 & 4254,93 & 0,35 & 0,36 & 0,00 & & & 3,03 & 4,39 & & 0,50 & 1,45 & & & & \\
\hline set-95 & 4653,52 & 0,36 & 0,38 & 0,01 & & & & 4,43 & & 0,52 & 1,62 & & & & \\
\hline out-95 & 4439,13 & 0,33 & 0,37 & 0,00 & & & & 4,42 & & 0,50 & 1,55 & & & & \\
\hline nov-95 & 4071,14 & 0,31 & 0,35 & 0,00 & & & & 4,25 & & 0,44 & 1,48 & & & & \\
\hline dez-95 & 4271,94 & 0,33 & 0,35 & 0,00 & & & 3,53 & 3,56 & & 0,46 & 1,17 & & & & \\
\hline jan-96 & 4825,45 & 0,36 & 0,38 & 0,00 & & & & 2,97 & & 0,53 & 1,26 & & & & \\
\hline fev-96 & 5271,50 & 0,41 & 0,38 & 0,00 & & & 3,28 & 2,99 & & 0,60 & 1,51 & & & & \\
\hline mar-96 & 4929,67 & 0,42 & 0,43 & 0,00 & & & 2,27 & 2,93 & & 0,55 & 1,31 & & & & \\
\hline abr-96 & 5017,08 & 0,40 & 0,56 & 0,00 & & & & 2,92 & & 0,54 & 1,14 & & & & \\
\hline mai-96 & 5482,80 & 0,45 & 0,70 & 0,00 & & & & 2,89 & & 0,63 & 1,05 & & & & \\
\hline jun-96 & 5786,47 & 0,45 & 0,69 & 0,00 & & & & 3,03 & & 0,67 & 0,98 & & & & \\
\hline jul-96 & 6272,26 & 0,48 & 0,71 & 0,00 & & & 2,52 & 3,16 & & 0,71 & 1,01 & & & & \\
\hline ago-96 & 6249,75 & 0,48 & 0,74 & 0,00 & & & 2,90 & 3,18 & & 0,73 & 1,09 & & & & \\
\hline set-96 & 6434,99 & 0,48 & 0,77 & 0,01 & & & & 3,23 & & 0,74 & 1,11 & & & & \\
\hline out-96 & 6627,31 & 0,50 & 0,73 & 0,01 & & & 2,59 & 3,22 & & 0,76 & 1,06 & & & & \\
\hline nov-96 & 6611,83 & 0,50 & 0,76 & 0,00 & & & 2,21 & 3,19 & & 0,73 & 1,05 & & & & \\
\hline dez-96 & 6841,96 & 0,48 & 0,75 & 0,00 & & & & 3,21 & & 0,69 & 1,06 & & & & \\
\hline jan-97 & 7602,23 & 0,49 & 0,74 & 0,01 & & & 1,89 & 3,41 & & 0,75 & 1,03 & & & & \\
\hline
\end{tabular}




\begin{tabular}{|c|c|c|c|c|c|c|c|c|c|c|c|c|c|c|c|}
\hline$\stackrel{\leftrightarrow}{\sum}$ & 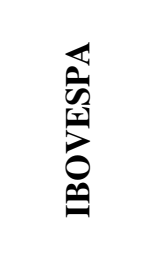 & 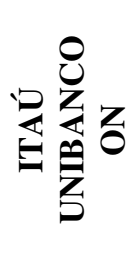 & 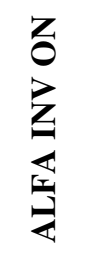 & 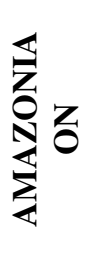 & 资 & 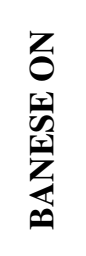 & 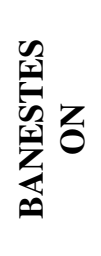 & $\frac{5}{S_{0}}$ & 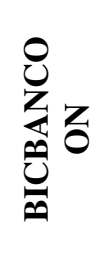 & 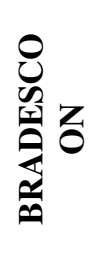 & 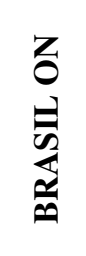 & 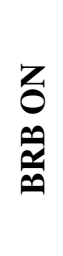 & 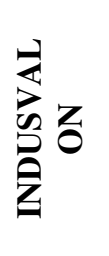 & 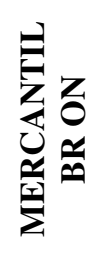 & 帘 \\
\hline fev-97 & 8642,73 & 0,58 & 0,76 & 0,01 & & & 2,04 & 3,47 & & 0,81 & 1,06 & & & & \\
\hline mar-97 & 9241,00 & 0,61 & 0,76 & 0,01 & & & & 3,44 & & 0,85 & 1,03 & & & & \\
\hline abr-97 & 9596,19 & 0,62 & 0,78 & 0,01 & & & & & & 0,85 & 0,95 & & & & \\
\hline mai-97 & 10597,90 & 0,62 & 0,78 & 0,01 & & & & 3,32 & & 0,86 & 0,92 & & & & \\
\hline jun-97 & 11933,67 & 0,58 & 0,72 & 0,02 & & & 1,26 & 3,11 & & 0,94 & 1,19 & & & & \\
\hline jul-97 & 12711,36 & 0,68 & 0,78 & 0,02 & & & 1,54 & 3,04 & & 1,06 & 1,26 & & & & \\
\hline ago-97 & 11636,95 & 0,68 & 0,80 & 0,01 & 1,70 & & 4,54 & 5,68 & & 1,09 & 1,24 & & & & \\
\hline set-97 & 11395,41 & 0,66 & 0,84 & 0,01 & & & 4,35 & 4,94 & & 1,06 & 1,16 & & & & \\
\hline out-97 & 11898,04 & 0,69 & 0,90 & 0,01 & & & 3,35 & 3,32 & & 1,17 & 1,13 & & & & \\
\hline nov-97 & 9168,20 & 0,51 & 0,80 & 0,01 & & & 2,17 & 2,92 & & 0,83 & 0,77 & & & & \\
\hline dez-97 & 9710,85 & 0,55 & 0,73 & 0,01 & & & 2,10 & 2,92 & & 0,96 & 0,79 & & & & \\
\hline jan-98 & 9658,33 & 0,65 & 0,75 & 0,01 & & 2,24 & 2,77 & & & 0,97 & 0,85 & & & & \\
\hline fev-98 & 10270,67 & 0,66 & 0,66 & 0,01 & & 1,76 & 2,22 & 2,41 & & 1,05 & 0,87 & & & & \\
\hline mar-98 & 11525,91 & 0,70 & 0,71 & 0,02 & & 2,04 & 2,18 & 2,59 & & 1,14 & 0,94 & & & & \\
\hline abr-98 & 11823,74 & 0,78 & 0,93 & 0,02 & & 1,70 & 2,15 & 3,04 & & 1,15 & 1,32 & & & 3,45 & \\
\hline mai-98 & 10568,20 & 0,74 & 1,22 & 0,02 & & 1,73 & 1,78 & 2,05 & & 0,99 & 1,29 & & & & \\
\hline jun-98 & 9793,19 & 0,71 & 1,18 & 0,02 & & 1,73 & 1,73 & 1,80 & & 0,96 & 1,11 & & & & \\
\hline jul-98 & 10529,23 & 0,80 & 1,12 & 0,03 & & & & & & 0,99 & 1,15 & & & & \\
\hline ago-98 & 8428,10 & 0,79 & 1,10 & 0,03 & & & 1,49 & 1,15 & & 0,86 & 1,01 & & & & \\
\hline set-98 & 6388,52 & 0,64 & 1,07 & 0,02 & & 1,12 & 1,22 & 0,84 & & 0,72 & 0,82 & & & & \\
\hline out-98 & 6696,29 & 0,70 & 1,00 & 0,02 & & 0,81 & 1,05 & & & 0,72 & 0,75 & & & & \\
\hline nov-98 & 8255,70 & 0,84 & 0,98 & 0,03 & & 0,67 & 0,92 & & & 0,86 & 0,83 & & & & \\
\hline dez-98 & 7282,25 & 0,78 & 1,22 & 0,03 & & 0,71 & 0,66 & 0,15 & & 0,76 & 0,78 & & & & \\
\hline jan-99 & 7001,11 & 0,75 & 1,20 & 0,03 & & 0,61 & 0,80 & & & 0,71 & 0,72 & & & 3,22 & \\
\hline fev-99 & 8837,61 & 0,85 & 1,10 & 0,03 & & & & 0,15 & & 0,83 & 0,78 & & & & \\
\hline mar-99 & 10170,04 & 0,94 & 0,95 & 0,03 & & 0,42 & 0,80 & & & 0,89 & 0,84 & & & & \\
\hline abr-99 & 11193,42 & 1,01 & 0,90 & 0,04 & & 0,61 & 0,29 & & & 0,87 & 0,88 & & & & \\
\hline mai-99 & 11729,95 & 1,15 & 0,92 & 0,05 & & 0,58 & 0,44 & 0,15 & & 0,93 & 0,91 & & & & \\
\hline
\end{tabular}




\begin{tabular}{|c|c|c|c|c|c|c|c|c|c|c|c|c|c|c|c|}
\hline$\stackrel{\Theta}{\sum}$ & \begin{tabular}{l}
$\overleftarrow{4}$ \\
\multirow{n}{n}{} \\
0 \\
0 \\
0 \\
0
\end{tabular} & 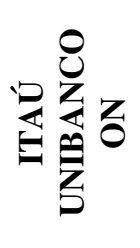 & $\begin{array}{l}z \\
0 \\
z \\
z \\
4 \\
4 \\
\vdots\end{array}$ & 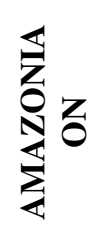 & 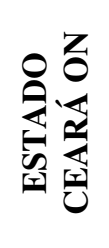 & 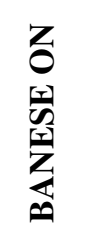 & 商 & $\frac{B}{\sum_{0}}$ & $\begin{array}{l}0 \\
\sum_{1} \\
0 \\
0 \\
0 \\
0\end{array}$ & 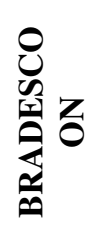 & 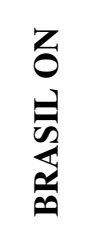 & 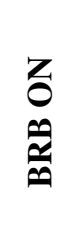 & 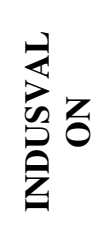 & 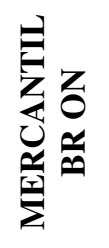 & 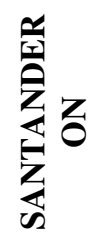 \\
\hline jun-99 & 11359,24 & 1,15 & 0,93 & 0,06 & & 0,52 & 0,82 & 0,19 & & 0,86 & 0,84 & & & & \\
\hline jul-99 & 11260,10 & 1,17 & 0,96 & 0,07 & & 0,40 & 0,69 & 0,27 & & 0,82 & 0,77 & & & & \\
\hline ago-99 & 10181,23 & 1,13 & 0,99 & 0,07 & & 0,33 & 0,72 & 0,18 & & 0,74 & 0,69 & & & & \\
\hline set-99 & 11313,10 & 1,24 & 1,05 & 0,08 & & 0,26 & 0,82 & & & 0,81 & 0,75 & & & & \\
\hline out-99 & 11309,25 & 1,29 & 1,23 & 0,09 & & 0,26 & & 0,13 & & 0,94 & 0,76 & & & 3,13 & \\
\hline nov-99 & 13120,40 & 1,55 & 1,33 & 0,11 & & 0,26 & & 0,13 & & 1,05 & 0,88 & & & 3,22 & \\
\hline dez-99 & 15085,57 & 1,83 & 1,43 & 0,12 & & 0,35 & 0,82 & 0,21 & & 1,31 & 0,95 & & & & \\
\hline jan-00 & 16926,05 & 2,07 & 1,82 & 0,12 & 1,70 & 0,80 & 1,18 & 0,33 & & 1,50 & 1,00 & & & & \\
\hline fev-00 & 17803,57 & 1,87 & 1,96 & 0,12 & & & 1,21 & 0,34 & & 1,43 & 0,96 & & & & \\
\hline mar-00 & 18054,90 & 1,92 & 2,15 & 0,12 & & & 0,80 & 0,31 & & 1,38 & 0,85 & & & & \\
\hline abr-00 & 15909,63 & 1,91 & 2,31 & 0,12 & & & & 0,22 & & 1,31 & 0,72 & & & & \\
\hline mai-00 & 14693,73 & 1,86 & 2,20 & 0,11 & & & 1,04 & 0,19 & & 1,25 & 0,74 & & & & \\
\hline jun-00 & 16457,52 & 2,03 & 2,00 & 0,11 & & 0,22 & 0,96 & 0,24 & & 1,45 & 0,77 & & & & \\
\hline jul-00 & 17086,67 & 2,19 & 1,97 & 0,10 & & & & 0,22 & & 1,57 & 0,80 & & & 3,22 & \\
\hline ago-00 & 17169,87 & 2,27 & 2,04 & 0,11 & & & & 0,24 & & 1,67 & 0,81 & & & 3,01 & \\
\hline set-00 & 16658,60 & 2,29 & 1,93 & 0,11 & & & & 0,27 & & 1,65 & 0,83 & & & & \\
\hline out -00 & 15043,71 & 2,22 & 1,76 & 0,11 & & & & 0,21 & & 1,47 & 0,78 & & & 3,62 & \\
\hline nov-00 & 14406,10 & 2,57 & 1,68 & 0,11 & & & & & & 1,65 & 0,77 & & & & \\
\hline dez-00 & 14714,68 & 2,76 & 1,65 & 0,11 & & & 0,96 & & & 1,84 & 0,78 & & & & \\
\hline jan-01 & 17120,00 & 2,98 & 1,70 & 0,12 & & & 0,96 & 0,37 & & 2,15 & 1,00 & & & & \\
\hline fev-01 & 16596,17 & 2,80 & 1,69 & 0,13 & & & & 0,50 & & 1,93 & 0,97 & & & & \\
\hline mar-01 & 15329,27 & 2,75 & 1,71 & 0,14 & & & & 0,51 & & 1,81 & 1,00 & & & & \\
\hline abr-01 & 14431,70 & 2,66 & 1,89 & 0,14 & & & 0,85 & 0,52 & & 1,84 & 1,11 & & & & \\
\hline mai-01 & 14688,05 & 2,85 & 1,89 & 0,16 & & & 0,53 & 0,49 & & 1,92 & 1,11 & & & & \\
\hline jun-01 & 14865,80 & 2,97 & 1,84 & 0,17 & & & 0,56 & 0,59 & & 1,93 & 1,15 & & & & \\
\hline jul-01 & 13944,95 & 2,94 & 1,86 & 0,13 & & & 0,75 & & & 1,84 & 1,22 & & & & \\
\hline ago-01 & 13412,74 & 2,93 & 1,91 & 0,14 & & & & 0,36 & & 1,83 & 1,24 & & & & \\
\hline set-01 & 11011,63 & 2,62 & 1,82 & 0,13 & & & & 0,33 & & 1,63 & 1,08 & & & & \\
\hline out-01 & 10963,36 & 2,75 & 1,64 & 0,12 & & & & & & 1,62 & 0,98 & & & & \\
\hline
\end{tabular}




\begin{tabular}{|c|c|c|c|c|c|c|c|c|c|c|c|c|c|c|c|}
\hline$\stackrel{\leftrightarrow}{\sum}$ & 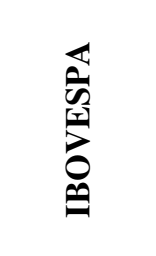 & 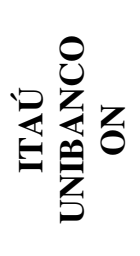 & $\begin{array}{l}z \\
0 \\
z \\
z \\
4 \\
z \\
z\end{array}$ & 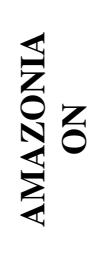 & 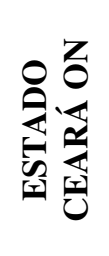 & 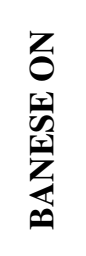 & 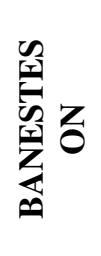 & $\frac{5}{\sum_{0}}$ & $\begin{array}{l}0 \\
0 \\
\sum^{\prime} z \\
0 \\
0 \\
0\end{array}$ & 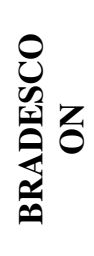 & 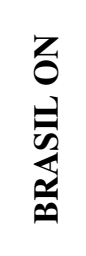 & 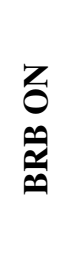 & 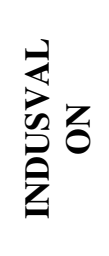 & 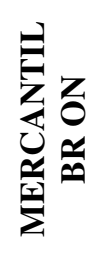 & 帘 \\
\hline nov-01 & 12798,15 & 2,92 & 1,69 & 0,14 & & & & & & 1,84 & 1,17 & & & & \\
\hline dez-01 & 13318,94 & 2,78 & 1,91 & 0,14 & 1,70 & & & 0,63 & & 1,87 & 1,35 & & & & \\
\hline jan-02 & 13400,86 & 2,85 & 1,97 & 0,12 & & & 0,73 & & & 2,06 & 1,34 & & & & \\
\hline fev-02 & 13226,22 & 2,95 & 2,07 & 0,12 & & & & & & 2,10 & 1,34 & & & & \\
\hline mar-02 & 13901,25 & 3,07 & 2,32 & 0,12 & & 0,15 & 0,75 & & & 2,25 & 1,59 & & & & \\
\hline abr-02 & 13343,32 & 3,07 & 2,30 & 0,08 & & & 0,74 & & & 2,42 & 1,84 & & & & \\
\hline mai-02 & 12515,00 & 2,89 & 2,36 & 0,07 & & & 0,67 & & & 2,12 & 1,70 & & & & \\
\hline jun-02 & 11685,25 & 2,63 & 2,44 & 0,07 & & & 0,51 & & & 1,91 & 1,45 & & & & \\
\hline jul-02 & 10305,59 & 2,38 & 2,72 & 0,05 & & & & 0,42 & & 1,77 & 1,29 & & & & \\
\hline ago-02 & 9790,95 & 2,17 & 2,98 & 0,06 & & & & & & 1,66 & 1,33 & & & & \\
\hline set-02 & 9643,52 & 2,15 & 2,87 & 0,06 & 1,59 & & & & & 1,59 & 1,37 & & & & \\
\hline out-02 & 9179,43 & 2,17 & 2,85 & 0,05 & & & 0,51 & & & 1,48 & 1,27 & & & & \\
\hline nov-02 & 10029,80 & 2,37 & 2,51 & 0,05 & 1,55 & & 0,83 & 0,79 & & 1,57 & 1,44 & & & & \\
\hline dez-02 & 10840,11 & 2,48 & 2,44 & 0,06 & & 0,15 & 0,55 & & & 1,74 & 1,39 & & & & \\
\hline jan-03 & 11485,64 & 2,68 & 2,51 & 0,06 & 1,33 & 0,24 & 0,54 & 0,79 & & 2,00 & 1,42 & & & & \\
\hline fev-03 & 10350,45 & 2,50 & 2,49 & 0,06 & & & 0,52 & & & 1,81 & 1,38 & & & & \\
\hline mar-03 & 10917,32 & 2,73 & 2,80 & 0,06 & & & & & & 1,98 & 1,52 & & & & \\
\hline abr-03 & 12085,95 & 3,08 & 3,34 & 0,06 & 1,26 & & 0,54 & & & 2,10 & 1,80 & & & & \\
\hline mai-03 & 13090,95 & 3,13 & 2,82 & 0,07 & 1,69 & 0,39 & 0,54 & 0,78 & & 2,13 & 2,04 & & & & \\
\hline jun-03 & 13490,30 & 3,08 & 2,77 & 0,08 & & 0,39 & 0,54 & & & 2,06 & 2,16 & & & & \\
\hline jul-03 & 13549,27 & 3,05 & 3,36 & 0,07 & 1,59 & & 0,67 & 0,59 & & 2,04 & 2,08 & & & & \\
\hline ago-03 & 14007,90 & 3,26 & 3,62 & 0,07 & 1,42 & 0,42 & 0,73 & 0,59 & & 2,11 & 2,27 & & & 4,11 & \\
\hline set-03 & 16093,95 & 3,72 & 4,28 & 0,07 & & 0,49 & 0,73 & 0,59 & & 2,19 & 2,55 & & & & \\
\hline out-03 & 17781,13 & 3,65 & 4,42 & 0,07 & 1,83 & 0,50 & 0,83 & 0,67 & & 2,17 & 2,75 & & & & \\
\hline nov-03 & 19011,55 & 3,80 & 3,74 & 0,07 & 1,79 & & 0,78 & 0,69 & & 2,35 & 3,20 & & & & \\
\hline dez-03 & 21157,20 & 4,13 & 3,74 & 0,08 & 2,51 & 0,60 & 0,70 & 0,69 & & 2,88 & 3,70 & & & & \\
\hline jan-04 & 23412,24 & 4,55 & 3,82 & 0,10 & 2,59 & 0,69 & 0,74 & 0,81 & & 3,08 & 3,68 & & & & \\
\hline fev-04 & 21969,06 & 4,60 & 3,64 & 0,10 & & & 0,65 & 0,95 & & 2,84 & 3,38 & & & & \\
\hline
\end{tabular}




\begin{tabular}{|c|c|c|c|c|c|c|c|c|c|c|c|c|c|c|c|}
\hline$\stackrel{\Theta}{\sum}$ & \begin{tabular}{l}
$\overleftarrow{4}$ \\
\multirow{n}{n}{} \\
0 \\
0 \\
0 \\
0
\end{tabular} & 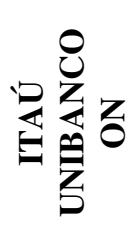 & $\begin{array}{l}z \\
0 \\
z \\
z \\
4 \\
4 \\
\vdots\end{array}$ & 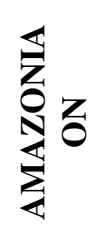 & 悹染 & 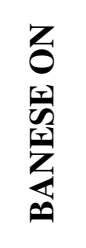 & 空空 & $\frac{5}{\sum_{0}}$ & 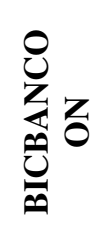 & 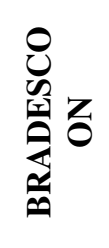 & 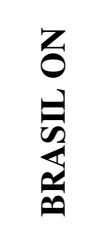 & 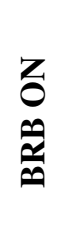 & 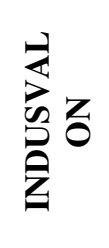 & 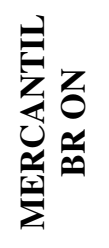 & 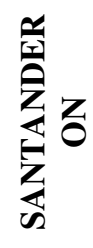 \\
\hline mar-04 & 21917,74 & 4,64 & 3,63 & 0,11 & 3,23 & & 0,60 & & & 2,82 & 3,59 & & & & \\
\hline abr-04 & 21810,65 & 4,55 & 3,58 & 0,11 & 3,37 & & 0,60 & 1,08 & & 2,63 & 3,41 & & & & \\
\hline mai-04 & 18878,14 & 4,14 & 3,39 & 0,11 & 3,25 & 0,70 & 0,61 & & & 2,34 & 3,05 & & & & \\
\hline jun-04 & 20221,38 & 4,39 & 3,51 & 0,11 & 3,55 & & 0,56 & & & 2,60 & 3,36 & & & & \\
\hline jul-04 & 21742,95 & 4,63 & 3,50 & 0,12 & 3,55 & 0,69 & 0,51 & 1,20 & & 2,73 & 3,60 & & & 6,02 & \\
\hline ago-04 & 22267,05 & 4,69 & 3,51 & 0,12 & 3,34 & 0,69 & 0,56 & 1,72 & & 2,70 & 3,69 & & & & \\
\hline set-04 & 22698,86 & 4,85 & 3,55 & 0,12 & 3,22 & 0,69 & 0,58 & 1,51 & & 2,74 & 3,93 & & & & \\
\hline out-04 & 23366,30 & 5,19 & 3,55 & 0,13 & 2,90 & & 0,60 & 1,85 & & 3,16 & 4,45 & & & & \\
\hline nov-04 & 24045,10 & 5,26 & 3,50 & 0,14 & 2,83 & 0,75 & 0,61 & & & 3,34 & 4,97 & & & & \\
\hline dez-04 & 25535,05 & 6,05 & 3,69 & 0,14 & 2,99 & 0,76 & 0,53 & 1,61 & & 3,96 & 5,24 & & & & \\
\hline jan-05 & 24432,40 & 6,34 & 3,71 & 0,14 & 2,86 & 0,86 & 0,58 & 1,72 & & 3,79 & 5,05 & & & & \\
\hline fev-05 & 26551,00 & 6,72 & 3,76 & 0,14 & 3,05 & & 0,58 & 1,61 & & 4,90 & 5,48 & & & & \\
\hline mar-05 & 27671,32 & 7,56 & 3,98 & 0,12 & 3,06 & 1,11 & 0,66 & 1,96 & & 5,27 & 5,08 & & & & \\
\hline abr-05 & 25512,15 & 7,28 & 3,95 & 0,11 & 3,90 & & 0,57 & 1,74 & & 4,83 & 4,70 & & & & \\
\hline mai-05 & 24809,86 & 6,99 & 3,79 & 0,11 & 4,06 & & 0,55 & 2,02 & & 5,17 & 4,95 & & & & \\
\hline jun-05 & 25430,64 & 6,94 & 3,80 & 0,11 & & & 0,57 & 2,13 & & 5,46 & 5,06 & & & & \\
\hline jul-05 & 25254,05 & 6,87 & 3,88 & 0,10 & & & 0,60 & 1,95 & & 5,73 & 4,95 & & & & \\
\hline ago-05 & 27007,26 & 7,46 & 3,79 & 0,10 & 4,92 & 1,55 & 0,71 & 2,07 & & 6,34 & 5,77 & & & & \\
\hline set-05 & 29859,38 & 8,80 & 3,67 & 0,10 & 6,78 & & 0,73 & 1,89 & & 7,29 & 6,47 & & & & \\
\hline out-05 & 29843,50 & 8,61 & 3,53 & 0,10 & 4,93 & 3,08 & 0,71 & 1,75 & & 7,75 & 6,88 & & & & \\
\hline nov-05 & 31146,20 & 8,79 & 3,53 & 0,10 & & & 0,69 & 1,82 & & 8,94 & 7,02 & & & & \\
\hline dez-05 & 33129,67 & 9,21 & 3,92 & 0,11 & 6,29 & 3,40 & 0,70 & 1,88 & & 9,88 & 7,10 & & & & \\
\hline jan-06 & 36189,19 & 9,99 & 4,01 & 0,12 & 7,28 & 4,00 & 0,73 & 2,57 & & 10,76 & 8,73 & & & & \\
\hline fev-06 & 37550,39 & 10,97 & 4,20 & 0,15 & 8,24 & 3,91 & 0,84 & 2,89 & & 12,03 & 9,64 & & & & \\
\hline mar-06 & 37766,52 & 11,18 & 4,46 & 0,18 & 8,39 & 3,68 & 1,28 & 2,95 & & 11,70 & 9,46 & & & & \\
\hline abr-06 & 39190,28 & 10,80 & 4,41 & 0,19 & 8,45 & & 1,30 & 3,05 & & 10,80 & 9,50 & & & & \\
\hline mai-06 & 39037,59 & 10,92 & 4,45 & 0,19 & 9,10 & & 1,24 & 3,41 & & 11,44 & 10,39 & & & & \\
\hline jun-06 & 35071,86 & 9,71 & 4,54 & 0,17 & & & 1,46 & 3,25 & & 9,43 & 8,98 & & & & \\
\hline jul-06 & 36301,95 & 10,44 & 4,58 & 0,17 & & & 1,14 & 3,36 & & 9,92 & 8,31 & & & & \\
\hline
\end{tabular}




\begin{tabular}{|c|c|c|c|c|c|c|c|c|c|c|c|c|c|c|c|}
\hline$\sum_{\Sigma}^{\mathscr{e}}$ & 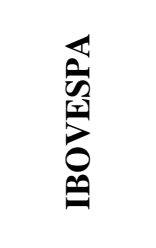 & 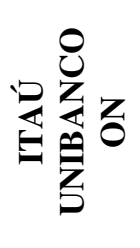 & 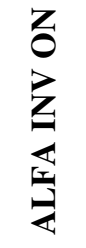 & 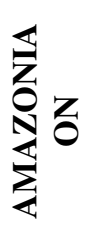 & 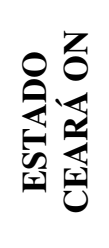 & 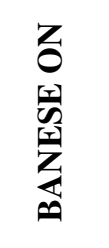 & 资 & $\frac{5}{\sum_{0}}$ & 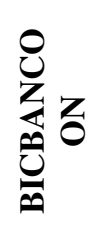 & 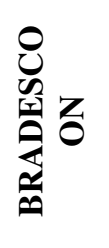 & 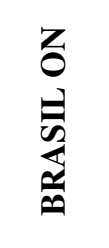 & 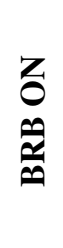 & 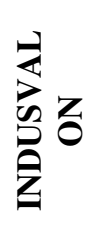 & 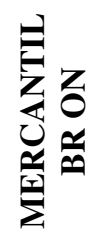 & 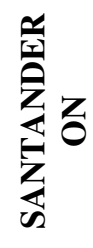 \\
\hline ago-06 & 36923,30 & 10,57 & 4,49 & 0,18 & & & 1,13 & 3,50 & & 10,34 & 8,60 & & & 6,18 & \\
\hline set-06 & 36173,30 & 10,67 & 4,84 & 0,15 & & 7,91 & 1,10 & 3,57 & & 10,42 & 8,65 & & & 6,18 & \\
\hline out-06 & 38627,76 & 11,41 & 4,95 & 0,15 & & 8,28 & 1,37 & 4,14 & & 11,44 & 9,19 & & & & \\
\hline nov-06 & 41198,84 & 11,67 & 4,86 & 0,16 & & 10,08 & 1,81 & 4,43 & & 11,74 & 10,00 & & & 6,18 & \\
\hline dez-06 & 43316,26 & 12,01 & 5,11 & 0,18 & & 10,23 & 2,00 & 5,45 & & 12,19 & 11,40 & & & 6,30 & \\
\hline jan-07 & 43442,52 & 12,64 & 5,22 & 0,21 & & & 2,44 & 6,06 & & 13,23 & 12,28 & & & 6,30 & \\
\hline fev-07 & 45163,44 & 12,58 & 5,64 & 0,22 & & 11,14 & 2,44 & 7,29 & & 12,94 & 12,51 & & & 7,38 & \\
\hline mar-07 & 43999,18 & 12,14 & 5,82 & 0,21 & & 9,68 & 2,34 & 6,65 & & 12,63 & 12,33 & & & 7,71 & \\
\hline abr-07 & 48051,85 & 13,02 & 6,45 & 0,23 & & 10,47 & 2,47 & 7,92 & & 13,51 & 12,93 & & & 8,29 & 5,20 \\
\hline mai-07 & 51225,91 & 14,70 & 7,87 & 0,58 & & 12,29 & 3,31 & 11,80 & & 15,19 & 14,48 & & & 10,93 & 5,24 \\
\hline jun-07 & 53644,90 & 15,22 & 8,21 & 0,68 & & & 3,90 & 15,01 & & 15,67 & 15,50 & & & 9,83 & 5,41 \\
\hline jul-07 & 56199,52 & 16,03 & 8,44 & 0,97 & & 14,27 & 6,35 & 15,03 & & 16,30 & 16,49 & & 8,66 & 10,48 & 6,29 \\
\hline ago-07 & 52162,39 & 15,20 & 7,76 & 0,89 & & 12,15 & 5,37 & 9,12 & & 15,57 & 15,67 & & & 9,66 & 5,54 \\
\hline set-07 & 56361,68 & 15,76 & 7,92 & 0,93 & & 12,11 & 5,45 & 7,06 & & 15,75 & 15,73 & & & 10,82 & 5,84 \\
\hline out-07 & 62680,41 & 17,90 & 8,69 & 0,80 & & 11,53 & 5,21 & 7,56 & 7,71 & 17,46 & 16,90 & & & 11,99 & 6,96 \\
\hline nov-07 & 62447,42 & 16,78 & 9,76 & 0,73 & & 11,62 & 4,49 & 6,67 & 6,68 & 16,83 & 15,96 & & & 11,21 & 8,59 \\
\hline dez-07 & 63469,06 & 17,83 & 8,86 & 0,65 & & 10,41 & 4,55 & 6,26 & 8,30 & 17,44 & 17,39 & & & 11,02 & 7,33 \\
\hline jan-08 & 59644,81 & 15,44 & 7,52 & 0,55 & & 10,37 & 4,05 & 5,75 & 7,37 & 15,05 & 16,68 & & & 10,48 & 6,72 \\
\hline fev-08 & 62535,68 & 14,98 & 7,53 & 0,50 & & 10,05 & 3,91 & 5,95 & 6,57 & 14,49 & 16,49 & & & 11,22 & 7,47 \\
\hline mar-08 & 61541,25 & 15,82 & 7,58 & 0,47 & & & 3,58 & 5,88 & & 14,78 & 14,71 & & & 11,34 & 7,25 \\
\hline abr-08 & 64235,62 & 15,91 & 6,97 & 0,45 & & & 2,71 & 5,94 & 6,77 & 14,85 & 14,28 & & & 10,85 & 7,13 \\
\hline mai-08 & 71209,10 & 17,21 & 7,36 & 0,51 & & 10,67 & 2,86 & 7,20 & 6,17 & 16,43 & 16,92 & & & 10,64 & 7,90 \\
\hline jun-08 & 67233,52 & 16,47 & 7,23 & 0,54 & & 15,86 & 2,63 & 6,60 & 6,80 & 15,31 & 16,74 & & & 11,12 & 7,63 \\
\hline jul-08 & 59769,73 & 14,95 & 6,91 & 0,44 & & 9,59 & 2,30 & 5,90 & 6,39 & 14,15 & 14,09 & & & 10,92 & 7,17 \\
\hline ago-08 & 55455,71 & 14,52 & 6,85 & 0,41 & & & 2,45 & 5,21 & 6,23 & 13,40 & 13,28 & & & 10,67 & 6,45 \\
\hline set-08 & 50594,09 & 14,30 & 6,90 & 0,34 & & 8,39 & 2,12 & 5,54 & 5,63 & 12,89 & 12,89 & & & 10,68 & 5,76 \\
\hline out-08 & 38142,35 & 11,79 & 6,09 & 0,24 & & 8,40 & 1,47 & 4,09 & & 10,70 & 9,25 & & & 7,67 & 4,92 \\
\hline nov-08 & 35907,74 & 10,92 & 5,52 & 0,26 & & & 1,70 & 4,56 & 3,58 & 9,72 & 8,28 & & & 6,92 & 5,18 \\
\hline
\end{tabular}




\begin{tabular}{|c|c|c|c|c|c|c|c|c|c|c|c|c|c|c|c|}
\hline$\sum^{\otimes}$ & $\begin{array}{l}\mathbb{a} \\
\text { ज } \\
0 \\
0 \\
0 \\
0\end{array}$ & 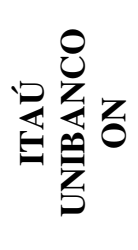 & $\begin{array}{l}z \\
0 \\
z \\
z \\
z \\
z \\
z\end{array}$ & 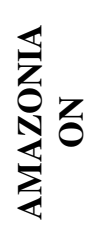 & 을 & 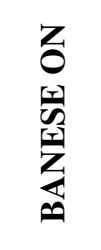 & 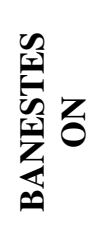 & 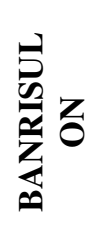 & $\begin{array}{l}0 \\
\underbrace{2} \\
\sum_{0}^{0} \\
0\end{array}$ & 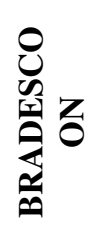 & $\begin{array}{l}Z \\
0 \\
0 \\
\frac{0}{\infty} \\
\frac{0}{\infty}\end{array}$ & $\begin{array}{l}\text { Z } \\
0 \\
0 \\
0\end{array}$ & 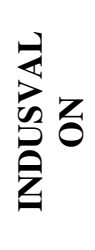 & 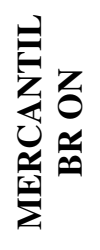 & 窝 \\
\hline dez-08 & 37557,35 & 12,12 & 5,84 & 0,26 & & 6,00 & 1,96 & 4,98 & 2,49 & 10,30 & 8,98 & & & 5,70 & 5,14 \\
\hline jan-09 & 39567,90 & 11,00 & 5,89 & 0,33 & & & 2,15 & 4,38 & 3,57 & 9,78 & 8,77 & 10,21 & & 5,63 & 5,05 \\
\hline fev-09 & 40173,78 & 10,55 & 5,74 & 0,38 & & & 2,97 & 4,40 & 3,55 & 9,39 & 8,42 & 12,52 & & 5,58 & 4,99 \\
\hline mar-09 & 39484,27 & 10,96 & 5,84 & 0,38 & & & 2,90 & 4,73 & 3,53 & 9,44 & 9,19 & 13,28 & & 5,31 & 4,60 \\
\hline abr-09 & 45217,15 & 12,43 & 6,25 & 0,39 & & & 2,91 & 5,42 & 4,13 & 10,72 & 11,20 & & 3,15 & 5,41 & 4,39 \\
\hline mai-09 & 50892,55 & 13,23 & 7,05 & 0,42 & & 5,59 & 3,30 & 5,38 & 4,43 & 11,95 & 12,63 & 13,28 & & 5,98 & 4,49 \\
\hline jun-09 & 52060,43 & 13,69 & 6,99 & 0,43 & & 8,65 & 3,11 & 5,57 & 5,20 & 12,24 & 13,27 & & & 6,74 & 4,63 \\
\hline jul-09 & 52067,32 & 13,84 & 6,80 & 0,42 & & 7,57 & 2,35 & 5,53 & 6,20 & 12,08 & 13,82 & & & 6,95 & 6,42 \\
\hline ago-09 & 56661,86 & 15,25 & 6,82 & 0,43 & & 8,13 & 2,54 & 6,36 & 6,97 & 12,69 & 15,89 & & & 7,65 & 8,06 \\
\hline set-09 & 59194,62 & 16,15 & 7,18 & 0,42 & & 8,26 & 2,60 & 7,41 & 7,45 & 13,92 & 18,00 & 13,41 & & 8,48 & 8,64 \\
\hline out-09 & 63989,43 & 17,03 & 7,35 & 0,45 & & & 2,66 & 8,15 & 8,97 & 14,95 & 19,27 & 14,55 & & 8,99 & 7,73 \\
\hline nov-09 & 65999,47 & 17,53 & 7,59 & 0,43 & & 8,41 & 2,61 & 8,44 & 9,13 & 14,97 & 19,58 & 14,71 & & 8,84 & 7,56 \\
\hline dez-09 & 68102,10 & 18,29 & 7,49 & 0,43 & & 8,64 & 2,54 & 8,68 & 9,88 & 15,77 & 19,23 & 15,78 & & 7,90 & 8,34 \\
\hline jan-10 & 68577,68 & 17,91 & 7,40 & 0,54 & & 8,68 & 2,55 & 9,10 & 9,04 & 15,57 & 18,68 & 16,94 & & 8,59 & 8,27 \\
\hline fev-10 & 65937,17 & 17,52 & 7,34 & 0,50 & & 8,86 & 2,47 & 9,14 & 9,15 & 14,79 & 19,27 & 14,67 & & 9,11 & 7,56 \\
\hline mar-10 & 69069,87 & 18,00 & 7,23 & 0,51 & & 10,31 & 2,46 & 9,40 & 9,91 & 14,84 & 19,41 & 16,89 & & 9,47 & 7,44 \\
\hline abr-10 & 69737,60 & 18,43 & 6,94 & 0,48 & & 9,77 & 2,37 & 9,48 & 10,61 & 14,95 & 19,78 & 17,16 & & 9,45 & 7,29 \\
\hline mai-10 & 62604,95 & 16,83 & 7,11 & 0,41 & & 9,28 & 2,08 & 8,23 & 9,60 & 14,12 & 17,76 & 20,41 & & 9,27 & 7,05 \\
\hline jun-10 & 63331,38 & 16,59 & 6,95 & 0,40 & & 9,31 & 2,09 & 8,18 & 8,98 & 14,06 & 17,88 & & & 10,85 & 7,24 \\
\hline jul-10 & 64143,00 & 17,58 & 6,67 & 0,42 & & 10,89 & 2,12 & 9,00 & 9,66 & 15,22 & 18,82 & 19,65 & & 11,43 & 7,86 \\
\hline ago-10 & 66576,32 & 17,82 & 6,72 & 0,42 & & 12,25 & 2,18 & 10,17 & 10,64 & 16,04 & 19,73 & 21,91 & & 12,21 & 8,68 \\
\hline set-10 & 67792,52 & 18,45 & 6,70 & 0,40 & & 12,57 & 2,16 & 10,70 & 10,64 & 16,29 & 19,94 & 25,16 & & 12,41 & 8,46 \\
\hline out-10 & 70618,45 & 19,87 & 7,08 & 0,40 & & 11,62 & 2,31 & 11,01 & 12,05 & 17,70 & 22,73 & 24,23 & & 12,19 & 9,76 \\
\hline nov-10 & 70379,60 & 19,82 & 7,20 & 0,40 & & & 2,32 & 11,76 & 12,59 & 17,67 & 22,80 & 26,41 & & 11,75 & 9,49 \\
\hline dez-10 & 68546,48 & 18,81 & 7,08 & 0,39 & & & 2,31 & 11,36 & 10,95 & 16,68 & 21,29 & 27,04 & 4,97 & 11,72 & 8,67 \\
\hline jan-11 & 69779,20 & 19,16 & 7,14 & 0,39 & & & 2,26 & 12,10 & 10,59 & 16,55 & 21,32 & 22,50 & & 12,27 & 8,57 \\
\hline fev-11 & 66515,40 & 18,31 & 7,07 & 0,38 & & & 2,20 & 11,09 & 9,64 & 16,16 & 20,26 & 22,56 & & 11,38 & 7,53 \\
\hline mar-11 & 67213,76 & 18,83 & 6,95 & 0,38 & & 15,37 & 2,32 & 11,10 & 9,16 & 16,66 & 19,89 & 23,05 & 4,97 & 11,74 & 7,53 \\
\hline abr-11 & 67424,32 & 19,95 & 6,98 & 0,38 & & 17,70 & 2,47 & 11,38 & 9,48 & 17,70 & 20,21 & 23,86 & & 11,89 & 6,95 \\
\hline
\end{tabular}




\begin{tabular}{|c|c|c|c|c|c|c|c|c|c|c|c|c|c|c|c|}
\hline$\sum_{\Sigma}^{\mathscr{e}}$ & 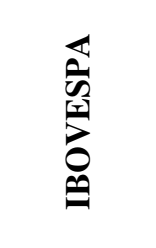 & 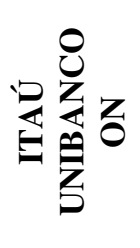 & $\begin{array}{l}z \\
0 \\
z \\
z \\
\frac{z}{2} \\
z \\
z\end{array}$ & 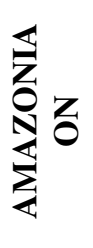 & 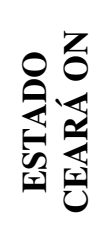 & 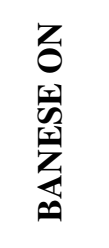 & 资 & $\frac{5}{\sum_{0}}$ & $\begin{array}{l}0 \\
0 \\
z \\
z \\
0 \\
0 \\
0\end{array}$ & 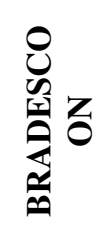 & 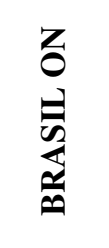 & 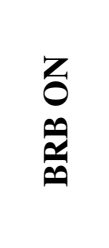 & 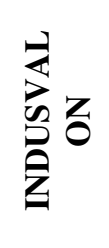 & 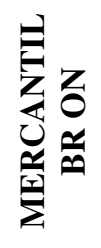 & 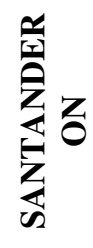 \\
\hline mai-11 & 63730,36 & 19,13 & 6,88 & 0,35 & & 20,23 & 2,39 & 10,40 & 10,07 & 17,10 & 19,58 & 23,48 & 5,63 & 12,12 & 6,34 \\
\hline jun-11 & 62298,76 & 19,02 & 6,86 & 0,34 & & & 2,33 & 10,27 & 9,05 & 17,14 & 19,25 & 23,28 & 5,63 & 12,04 & 6,28 \\
\hline jul-11 & 60431,38 & 18,03 & 6,78 & 0,34 & & & 2,27 & 10,58 & 8,29 & 16,68 & 18,77 & 23,11 & & 12,75 & 5,88 \\
\hline ago-11 & 53841,00 & 15,39 & 6,56 & 0,31 & & 18,01 & 2,35 & 10,35 & 7,85 & 15,13 & 17,80 & 23,63 & & 13,09 & 5,32 \\
\hline set-11 & 55398,86 & 16,29 & 6,48 & 0,30 & & 21,85 & 2,58 & 10,34 & & 15,59 & 18,52 & 24,07 & & 13,44 & 5,54 \\
\hline out-11 & 54668,85 & 17,27 & 6,24 & 0,29 & & & 2,40 & 10,22 & 6,16 & 15,76 & 17,45 & 23,63 & & 13,14 & 5,30 \\
\hline nov-11 & 57093,00 & 17,18 & 6,09 & 0,29 & & 23,85 & 2,56 & 11,00 & 6,22 & 16,17 & 17,69 & 23,69 & & 13,00 & 5,18 \\
\hline dez-11 & 57407,81 & 18,05 & 5,46 & 0,29 & & & 2,63 & 11,98 & 7,02 & 16,84 & 17,26 & 23,63 & & 12,65 & 5,57 \\
\hline jan-12 & 60697,62 & 19,24 & 5,34 & 0,29 & & 25,99 & 3,26 & 12,41 & 7,69 & 17,75 & 18,44 & 24,27 & & 12,64 & 5,90 \\
\hline fev-12 & 65483,11 & 20,23 & 5,17 & 0,31 & & 28,49 & 3,15 & 12,93 & 6,44 & 17,72 & 20,15 & 24,51 & & 13,39 & 6,77 \\
\hline mar-12 & 66612,23 & 20,91 & 5,08 & 0,33 & & 30,20 & 3,29 & 13,31 & 6,37 & 18,85 & 20,78 & 23,63 & & 14,39 & 6,91 \\
\hline abr-12 & 62578,95 & 18,51 & 5,11 & 0,32 & & & 3,13 & 13,34 & 6,33 & 17,77 & 17,99 & 23,81 & & 14,44 & 6,17 \\
\hline mai-12 & 57135,64 & 16,82 & 5,21 & 0,30 & & & 2,83 & & 5,97 & 16,56 & 15,91 & 23,63 & & 13,01 & 6,12 \\
\hline jun-12 & 54664,70 & 16,73 & 4,82 & 0,29 & & & 2,80 & 10,61 & 5,52 & 17,07 & 14,63 & & & 13,75 & 6,20 \\
\hline jul-12 & 54616,57 & 17,34 & 5,09 & 0,28 & & & 3,19 & 10,09 & 5,52 & 17,26 & 14,97 & & & 14,32 & 5,78 \\
\hline ago-12 & 58208,74 & 19,19 & 5,07 & 0,31 & & 29,64 & 2,88 & 11,52 & 5,52 & 18,96 & 17,74 & 23,66 & & 15,23 & 6,36 \\
\hline set-12 & 60056,68 & 19,20 & 5,64 & 0,33 & & 29,64 & 2,29 & 12,21 & 5,62 & 19,18 & 19,62 & 24,30 & & 15,18 & 6,75 \\
\hline out-12 & 58590,73 & 17,88 & 5,40 & 0,32 & & & 2,09 & 10,97 & 5,65 & 18,31 & 17,70 & 24,30 & & 14,34 & 5,91 \\
\hline nov-12 & 57222,63 & 18,58 & 5,40 & 0,31 & & & 2,10 & 10,41 & 5,66 & 20,15 & 16,77 & 24,30 & & 14,22 & 5,64 \\
\hline dez-12 & 59582,44 & 20,15 & 5,51 & 0,29 & & 28,45 & 2,09 & 10,37 & 5,66 & 23,61 & 18,29 & & & 14,06 & 5,81 \\
\hline jan-13 & 61533,19 & 22,72 & 5,50 & 0,30 & & & 2,29 & 10,97 & & 25,36 & 20,38 & & & 14,23 & 6,20 \\
\hline fev-13 & 57877,33 & 22,49 & 5,66 & 0,29 & & & 2,26 & 12,99 & 5,79 & 24,71 & 19,34 & 27,50 & & 14,59 & 5,66 \\
\hline mar-13 & 56797,45 & 24,08 & 6,39 & 0,29 & & & 2,23 & 13,60 & 5,79 & 25,84 & 21,29 & & & 15,10 & 6,04 \\
\hline abr-13 & 54758,77 & 23,05 & 6,28 & 0,30 & & 31,37 & 2,21 & 12,76 & 5,69 & 26,72 & 21,58 & & & 15,33 & 5,65 \\
\hline mai-13 & 55455,95 & 23,66 & 6,28 & 0,30 & & & 2,19 & 12,42 & 5,55 & 26,82 & 20,62 & & & 15,21 & 5,92 \\
\hline jun-13 & 49604,10 & 22,47 & 6,45 & 0,28 & & 30,50 & 2,14 & 11,34 & 5,37 & 24,64 & 18,46 & & 5,24 & 14,46 & 5,77 \\
\hline jul-13 & 47160,14 & 21,08 & 6,26 & 0,29 & & & 2,07 & 10,98 & & 24,13 & 17,79 & & 5,24 & 15,33 & 5,38 \\
\hline ago-13 & 50061,68 & 21,70 & 6,11 & 0,28 & & & 2,04 & 11,06 & & 24,19 & 18,49 & 27,31 & & 15,86 & 5,36 \\
\hline
\end{tabular}




\begin{tabular}{|c|c|c|c|c|c|c|c|c|c|c|c|c|c|c|c|}
\hline$\sum_{i}^{\mathscr{e}}$ & 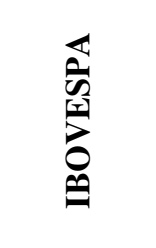 & 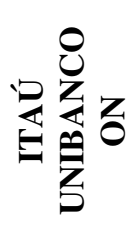 & 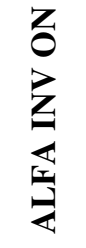 & 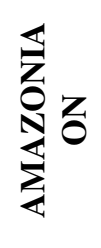 & 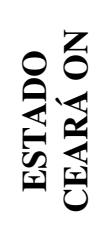 & 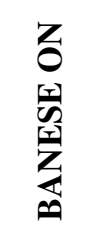 & 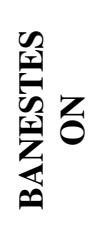 & $\frac{D_{0}}{\sum_{0}^{2}}$ & $\begin{array}{l}0 \\
Z \\
z \\
0 \\
0 \\
0 \\
0\end{array}$ & 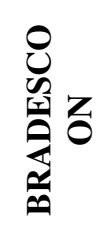 & $\begin{array}{l}z \\
0 \\
=1 \\
0 \\
0 \\
\frac{1}{x}\end{array}$ & 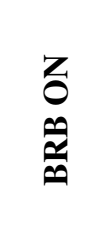 & 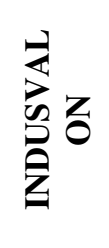 & 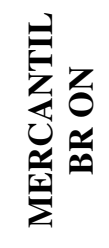 & 空 \\
\hline set-13 & 53634,81 & 22,61 & 6,12 & 0,28 & & 32,23 & 2,14 & 11,95 & 4,55 & 26,76 & 21,01 & 27,40 & 4,31 & 15,09 & 5,60 \\
\hline out-13 & 54171,43 & 23,42 & 6,37 & 0,28 & & & 2,20 & 12,20 & 6,67 & 28,12 & 23,48 & 27,42 & & 15,13 & 6,23 \\
\hline nov-13 & 52815,00 & 23,59 & 6,39 & 0,28 & & 32,23 & 2,19 & 11,57 & 7,49 & 26,93 & 22,98 & & & 14,98 & 6,23 \\
\hline dez-13 & 50791,32 & 22,26 & 6,58 & 0,27 & & & 2,15 & 10,95 & 7,77 & 24,83 & 21,03 & & & 12,90 & 5,90 \\
\hline jan-14 & 49139,27 & 21,40 & 6,46 & 0,27 & & 29,90 & 2,07 & 10,61 & & 23,44 & 19,40 & 25,65 & & 12,07 & 5,72 \\
\hline fev-14 & 47367,35 & 22,28 & 6,48 & 0,26 & & & 2,02 & & 7,48 & 22,77 & 17,95 & 25,57 & & 11,88 & 5,35 \\
\hline mar-14 & 47046,47 & 23,21 & 5,97 & 0,26 & & & 1,97 & 10,08 & 7,79 & 23,87 & 17,98 & 26,33 & & 11,40 & 5,46 \\
\hline abr-14 & 51469,60 & 25,91 & 5,88 & 0,28 & & & 1,98 & 10,30 & 8,00 & 27,38 & 20,98 & & & 10,55 & 5,86 \\
\hline mai-14 & 53121,71 & 26,59 & 6,16 & 0,27 & & & 1,95 & 9,73 & & 27,82 & 20,91 & 25,61 & & 11,79 & 6,71 \\
\hline jun-14 & 53655,47 & 26,13 & 6,24 & 0,27 & & & 1,90 & 10,37 & 7,66 & 26,91 & 22,50 & 25,61 & & 9,73 & 7,16 \\
\hline jul-14 & 55789,73 & 27,48 & 6,33 & 0,27 & & & 1,99 & 10,76 & 7,70 & 28,05 & 24,53 & & 2,24 & 9,18 & 7,13 \\
\hline ago-14 & 57748,38 & 29,88 & 6,43 & 0,27 & & & 2,15 & 10,91 & 7,50 & 30,02 & 26,67 & & 2,20 & 10,45 & 7,19 \\
\hline set-14 & 58277,82 & 29,82 & 6,30 & 0,27 & & & 2,30 & 12,24 & 7,50 & 30,74 & 29,07 & & 2,31 & 8,56 & 7,46 \\
\hline out-14 & 54342,30 & 27,38 & 6,22 & 0,25 & & & 2,16 & 11,45 & & 28,39 & 26,13 & & 2,31 & 7,13 & 7,03 \\
\hline nov-14 & 53578,63 & 28,62 & 6,03 & 0,25 & & 23,55 & 1,90 & 12,60 & & 29,20 & 24,66 & 24,70 & & 6,08 & 7,09 \\
\hline dez-14 & 50006,95 & 27,53 & 5,79 & 0,24 & & & 1,84 & 11,40 & 5,72 & 28,11 & 22,80 & & & 6,26 & 6,63 \\
\hline jan-15 & 31999,54 & 10,14 & 4,13 & 0,23 & 4,27 & 7,55 & 2,34 & 6,57 & 7,22 & 8,81 & 8,65 & 21,45 & 3,68 & 10,56 & 6,58 \\
\hline
\end{tabular}


APÊNDICE 4 - Retornos mensais das ações de bancos

\begin{tabular}{|c|c|c|c|c|c|c|c|c|c|c|c|c|c|c|c|}
\hline 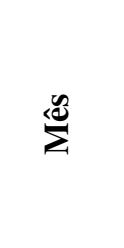 & 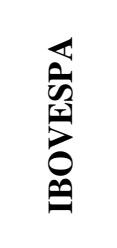 & 导 & $\begin{array}{l}z \\
0 \\
z \\
z \\
\vdots \\
\vdots \\
\vdots\end{array}$ & 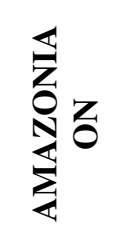 & 资 & 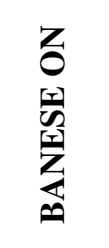 & 空 & $\frac{5}{\sum_{0}^{n}}$ & 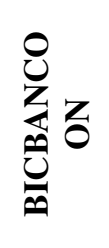 & 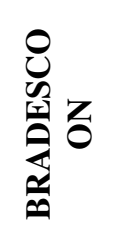 & 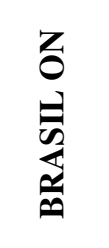 & 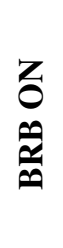 & 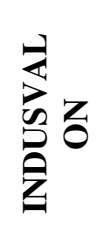 & 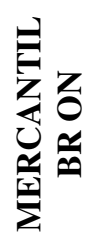 & 点 \\
\hline jan-05 & $-4,41$ & 4,68 & 0,60 & $-0,76$ & $-4,68$ & 13,29 & 9,25 & 6,52 & & $-4,21$ & $-3,69$ & & & & \\
\hline fev-05 & 8,32 & 5,80 & 1,36 & 2,47 & 6,68 & & $-0,47$ & $-6,49$ & & 25,48 & 8,12 & & & & \\
\hline mar-05 & 4,13 & 11,86 & 5,72 & $-12,75$ & 0,34 & & 12,22 & 19,48 & & 7,30 & $-7,57$ & & & & \\
\hline abr-05 & $-8,12$ & $-3,83$ & $-0,75$ & $-13,81$ & 24,18 & & $-14,11$ & $-11,65$ & & $-8,64$ & $-7,75$ & & & & \\
\hline mai-05 & $-2,79$ & $-4,02$ & $-4,13$ & $-1,58$ & 3,89 & & $-3,59$ & 15,09 & & 6,73 & 5,13 & & & & \\
\hline jun-05 & 2,47 & $-0,77$ & 0,29 & $-1,02$ & & & 4,02 & 4,96 & & 5,61 & 2,16 & & & & \\
\hline jul-05 & $-0,70$ & $-0,97$ & 1,99 & $-7,32$ & & & 5,16 & $-8,47$ & & 4,81 & $-2,17$ & & & & \\
\hline ago-05 & 6,71 & 8,19 & $-2,28$ & 1,31 & & & 16,66 & 5,61 & & 10,07 & 15,34 & & & & \\
\hline set-05 & 10,04 & 16,57 & $-3,32$ & 1,53 & 31,99 & & 2,50 & $-8,97$ & & 13,91 & 11,41 & & & & \\
\hline out-05 & $-0,05$ & $-2,22$ & $-3,88$ & $-2,69$ & $-31,86$ & & $-2,17$ & $-7,94$ & & 6,10 & 6,09 & & & & \\
\hline nov-05 & 4,27 & 2,05 & $-0,03$ & 1,66 & & & $-3,34$ & 4,29 & & 14,35 & 2,06 & & & & \\
\hline dez-05 & 6,17 & 4,67 & 10,61 & 5,50 & & & 1,02 & 3,01 & & 9,93 & 1,18 & & & & \\
\hline jan-06 & 8,83 & 8,13 & 2,18 & 15,64 & 14,68 & 16,20 & 4,28 & 31,21 & & 8,58 & 20,67 & & & & \\
\hline fev-06 & 3,69 & 9,41 & 4,72 & 20,54 & 12,38 & $-2,35$ & 14,28 & 12,04 & & 11,18 & 9,93 & & & & \\
\hline mar-06 & 0,57 & 1,86 & 6,09 & 15,70 & 1,76 & $-6,08$ & 42,22 & 2,00 & & $-2,80$ & $-1,93$ & & & & \\
\hline abr-06 & 3,70 & $-3,42$ & $-1,25$ & 4,00 & 0,76 & & 1,55 & 3,24 & & $-7,96$ & 0,46 & & & & \\
\hline mai-06 & $-0,39$ & 1,06 & 0,83 & 2,24 & 7,42 & & $-5,17$ & 11,20 & & 5,74 & 8,94 & & & & \\
\hline jun-06 & $-10,71$ & $-11,73$ & 2,03 & $-8,69$ & & & 16,53 & $-4,83$ & & $-19,33$ & $-14,55$ & & & & \\
\hline jul-06 & 3,45 & 7,27 & 0,91 & 0,39 & & & $-24,70$ & 3,17 & & 5,03 & $-7,83$ & & & & \\
\hline ago-06 & 1,70 & 1,18 & $-1,94$ & 1,14 & & & $-0,70$ & 4,09 & & 4,12 & 3,44 & & & & \\
\hline set-06 & $-2,05$ & 1,02 & 7,50 & $-15,05$ & & & $-3,15$ & 1,97 & & 0,85 & 0,56 & & & 0,00 & \\
\hline out-06 & 6,56 & 6,63 & 2,32 & $-0,25$ & & 4,60 & 22,03 & 15,00 & & 9,28 & 6,11 & & & & \\
\hline nov-06 & 6,44 & 2,28 & $-1,94$ & 6,27 & & 19,66 & 28,27 & 6,69 & & 2,57 & 8,46 & & & & \\
\hline dez-06 & 5,01 & 2,88 & 5,07 & 12,58 & & 1,47 & 9,95 & 20,66 & & 3,76 & 13,09 & & & 1,98 & \\
\hline jan-07 & 0,29 & 5,11 & 2,19 & 15,58 & & & 19,70 & 10,67 & & 8,21 & 7,41 & & & 0,00 & \\
\hline
\end{tabular}




\begin{tabular}{|c|c|c|c|c|c|c|c|c|c|c|c|c|c|c|c|}
\hline$\stackrel{\Theta}{\Sigma}$ & 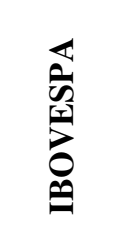 & 点艺 & $\begin{array}{l}z \\
0 \\
z \\
z \\
\frac{z}{3}\end{array}$ & 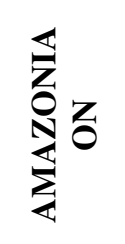 & 잉 & 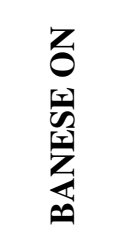 & 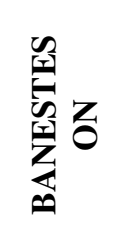 & $\sum_{\infty}^{\frac{a}{\sigma}}$ & $\begin{array}{l}0 \\
\sum_{0} \\
\sum_{0}^{\infty} \\
0\end{array}$ & 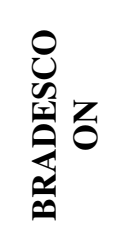 & $\begin{array}{l}Z \\
0 \\
0 \\
0 \\
\frac{0}{\infty}\end{array}$ & 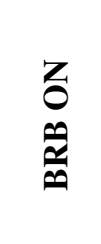 & 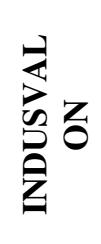 & 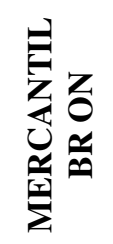 & 点 \\
\hline fev-07 & 3,88 & $-0,47$ & 7,63 & 2,10 & & & 0,05 & 18,54 & & $-2,22$ & 1,87 & & & 15,82 & \\
\hline mar-07 & $-2,61$ & $-3,56$ & 3,14 & $-4,27$ & & $-14,02$ & $-4,06$ & $-9,20$ & & $-2,43$ & $-1,46$ & & & 4,28 & \\
\hline abr-07 & 8,81 & 7,00 & 10,23 & 9,75 & & 7,78 & 5,18 & 17,40 & & 6,78 & 4,72 & & & 7,23 & \\
\hline mai-07 & 6,40 & 12,12 & 19,97 & 93,16 & & 16,07 & 29,46 & 39,91 & & 11,68 & 11,39 & & & 27,73 & 0,79 \\
\hline jun-07 & 4,61 & 3,49 & 4,24 & 15,64 & & & 16,34 & 24,08 & & 3,13 & 6,80 & & & $-10,65$ & 3,33 \\
\hline jul-07 & 4,65 & 5,17 & 2,79 & 34,73 & & & 48,78 & 0,09 & & 3,93 & 6,16 & & & 6,40 & 14,95 \\
\hline ago-07 & $-7,45$ & $-5,34$ & $-8,39$ & $-7,80$ & & $-16,09$ & $-16,75$ & $-49,97$ & & $-4,55$ & $-5,07$ & & & $-8,15$ & $-12,74$ \\
\hline set-07 & 7,74 & 3,67 & 1,95 & 4,24 & & $-0,32$ & 1,54 & $-25,49$ & & 1,10 & 0,34 & & & 11,32 & 5,36 \\
\hline out-07 & 10,63 & 12,73 & 9,30 & $-15,17$ & & $-4,92$ & $-4,51$ & 6,78 & & 10,31 & 7,18 & & & 10,27 & 17,57 \\
\hline nov-07 & $-0,37$ & $-6,47$ & 11,66 & $-9,85$ & & 0,75 & $-15,06$ & $-12,46$ & $-14,38$ & $-3,64$ & $-5,69$ & & & $-6,72$ & 20,95 \\
\hline dez-07 & 1,62 & 6,07 & $-9,74$ & $-10,66$ & & $-11,01$ & 1,48 & $-6,45$ & 21,70 & 3,56 & 8,55 & & & $-1,70$ & $-15,81$ \\
\hline jan-08 & $-6,21$ & $-14,40$ & $-16,32$ & $-17,77$ & & $-0,37$ & $-11,80$ & $-8,43$ & $-11,77$ & $-14,75$ & $-4,13$ & & & $-5,02$ & $-8,71$ \\
\hline fev-08 & 4,73 & $-3,01$ & 0,06 & $-8,47$ & & $-3,13$ & $-3,50$ & 3,33 & $-11,50$ & $-3,77$ & $-1,20$ & & & 6,86 & 10,63 \\
\hline mar-08 & $-1,60$ & 5,44 & 0,66 & $-6,11$ & & & $-8,76$ & $-1,15$ & & 1,93 & $-11,40$ & & & 0,99 & $-2,99$ \\
\hline abr-08 & 4,29 & 0,58 & $-8,36$ & $-5,73$ & & & $-27,78$ & 1,02 & & 0,53 & $-2,97$ & & & $-4,36$ & $-1,75$ \\
\hline mai-08 & 10,31 & 7,83 & 5,49 & 13,68 & & & 5,52 & 19,29 & $-9,26$ & 10,08 & 16,99 & & & $-2,00$ & 10,36 \\
\hline jun-08 & $-5,74$ & $-4,37$ & $-1,87$ & 4,78 & & 39,65 & $-8,37$ & $-8,71$ & 9,73 & $-7,04$ & $-1,06$ & & & 4,48 & $-3,58$ \\
\hline jul-08 & $-11,77$ & $-9,71$ & $-4,51$ & $-19,38$ & & $-50,30$ & $-13,76$ & $-11,32$ & $-6,18$ & $-7,87$ & $-17,27$ & & & $-1,87$ & $-6,19$ \\
\hline ago-08 & $-7,49$ & $-2,88$ & $-0,91$ & $-8,26$ & & & 6,68 & $-12,31$ & $-2,61$ & $-5,49$ & $-5,88$ & & & $-2,31$ & $-10,58$ \\
\hline set-08 & $-9,17$ & $-1,52$ & 0,86 & $-18,27$ & & & $-14,62$ & 6,18 & $-10,05$ & $-3,90$ & $-2,99$ & & & 0,15 & $-11,33$ \\
\hline out-08 & $-28,25$ & $-19,34$ & $-12,47$ & $-33,41$ & & 0,02 & $-36,86$ & $-30,32$ & & $-18,63$ & $-33,17$ & & & $-33,16$ & $-15,67$ \\
\hline nov-08 & $-6,04$ & $-7,69$ & $-9,85$ & 7,36 & & & 14,97 & 10,81 & & $-9,61$ & $-11,07$ & & & $-10,26$ & 5,13 \\
\hline dez-08 & 4,49 & 10,44 & 5,63 & 0,80 & & & 13,80 & 8,83 & $-36,15$ & 5,84 & 8,08 & & & $-19,35$ & $-0,89$ \\
\hline jan-09 & 5,21 & $-9,63$ & 0,88 & 21,19 & & & 9,42 & $-12,92$ & 35,97 & $-5,15$ & $-2,41$ & & & $-1,34$ & $-1,75$ \\
\hline fev-09 & 1,52 & $-4,25$ & $-2,72$ & 16,45 & & & 32,43 & 0,41 & $-0,46$ & $-4,09$ & $-3,98$ & 20,37 & & $-0,90$ & $-1,18$ \\
\hline mar-09 & $-1,73$ & 3,83 & 1,77 & $-0,44$ & & & $-2,61$ & 7,37 & $-0,65$ & 0,47 & 8,71 & 5,88 & & $-4,99$ & $-8,18$ \\
\hline abr-09 & 13,56 & 12,64 & 6,80 & 0,96 & & & 0,50 & 13,50 & 15,70 & 12,75 & 19,78 & & & 1,89 & $-4,49$ \\
\hline mai-09 & 11,82 & 6,18 & 12,07 & 7,40 & & & 12,67 & $-0,70$ & 7,04 & 10,83 & 12,00 & & & 10,06 & 2,14 \\
\hline jun-09 & 2,27 & 3,47 & $-0,90$ & 4,39 & & 43,62 & $-5,99$ & 3,48 & 15,95 & 2,41 & 4,95 & & & 11,96 & 3,13 \\
\hline
\end{tabular}




\begin{tabular}{|c|c|c|c|c|c|c|c|c|c|c|c|c|c|c|c|}
\hline$\stackrel{\Theta}{\sum}$ & 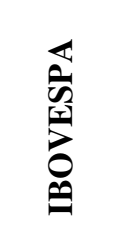 & 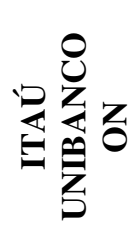 & $\begin{array}{l}z \\
0 \\
z \\
z \\
4 \\
4 \\
4\end{array}$ & 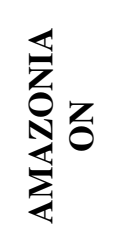 & 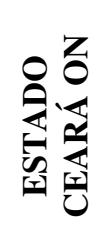 & 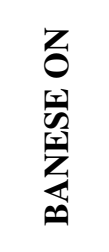 & 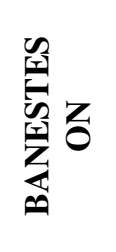 & $\frac{5}{\sum_{0}}$ & $\begin{array}{l}0 \\
Z \\
z \\
0 \\
0 \\
0 \\
0\end{array}$ & 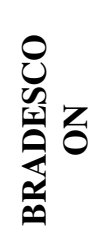 & $\begin{array}{l}z \\
0 \\
=1 \\
\frac{1}{0} \\
\frac{\pi}{x}\end{array}$ & 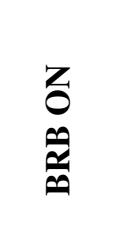 & 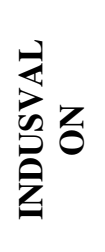 & 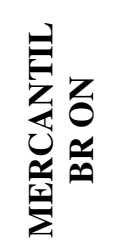 & 䍃 \\
\hline jul-09 & 0,01 & 1,08 & $-2,76$ & $-3,90$ & & $-13,34$ & $-28,11$ & \begin{tabular}{|l|}
$-0,68$ \\
\end{tabular} & 17,62 & $-1,32$ & 4,05 & & & 3,02 & 32,58 \\
\hline ago-09 & 8,46 & 9,69 & 0,37 & 2,32 & & 7,14 & 7,78 & 14,02 & 11,75 & 4,98 & 13,96 & & & 9,60 & 22,77 \\
\hline set-09 & 4,37 & 5,74 & 5,06 & $-0,92$ & & 1,55 & 2,32 & 15,23 & 6,54 & 9,23 & 12,49 & & & 10,32 & 6,98 \\
\hline out-09 & 7,79 & 5,28 & 2,43 & 5,39 & & & 2,49 & 9,51 & 18,62 & 7,12 & 6,80 & 8,13 & & 5,94 & $-11,08$ \\
\hline nov-09 & 3,09 & 2,91 & 3,17 & $-3,55$ & & & $-1,85$ & 3,47 & 1,81 & 0,13 & 1,59 & 1,12 & & $-1,76$ & $-2,18$ \\
\hline dez-09 & 3,14 & 4,22 & $-1,37$ & $-0,72$ & & 2,60 & $-2,86$ & 2,86 & 7,89 & 5,19 & $-1,79$ & 6,99 & & $-11,17$ & 9,78 \\
\hline jan-10 & 0,70 & $-2,09$ & $-1,16$ & 22,53 & & 0,49 & 0,29 & 4,72 & $-8,97$ & $-1,24$ & $-2,89$ & 7,10 & & 8,33 & $-0,87$ \\
\hline fev-10 & $-3,93$ & $-2,22$ & $-0,82$ & $-7,01$ & & 2,05 & $-3,30$ & 0,40 & 1,32 & $-5,17$ & 3,07 & $-14,38$ & & 5,82 & $-8,94$ \\
\hline mar-10 & 4,64 & 2,75 & $-1,47$ & 1,97 & & 15,19 & $-0,41$ & 2,87 & 7,93 & 0,33 & 0,77 & 14,09 & & 3,93 & $-1,64$ \\
\hline abr-10 & 0,96 & 2,32 & $-4,06$ & $-5,54$ & & $-5,37$ & $-3,37$ & 0,75 & 6,86 & 0,77 & 1,89 & 1,61 & & $-0,23$ & $-2,01$ \\
\hline mai-10 & $-10,79$ & $-9,05$ & 2,30 & $-15,39$ & & $-5,12$ & $-13,22$ & $-14,04$ & $-10,05$ & $-5,73$ & $-10,78$ & 17,36 & & $-1,92$ & $-3,39$ \\
\hline jun-10 & 1,15 & $-1,46$ & $-2,24$ & $-2,18$ & & 0,27 & 0,62 & $-0,62$ & $-6,64$ & $-0,43$ & 0,64 & & & 15,73 & 2,67 \\
\hline jul-10 & 1,27 & 5,82 & $-4,16$ & 3,21 & & 15,70 & 1,35 & 9,54 & 7,25 & 7,92 & 5,13 & & & 5,26 & 8,29 \\
\hline ago-10 & 3,72 & 1,36 & 0,79 & 1,18 & & 11,78 & 2,88 & 12,19 & 9,72 & 5,27 & 4,73 & 10,87 & & 6,57 & 9,84 \\
\hline set-10 & 1,81 & 3,44 & $-0,24$ & $-6,29$ & & 2,56 & $-1,20$ & 5,10 & 0,00 & 1,57 & 1,04 & 13,84 & & 1,60 & $-2,59$ \\
\hline out-10 & 4,08 & 7,44 & 5,41 & 1,47 & & $-7,86$ & 6,86 & 2,82 & 12,41 & 8,30 & 13,11 & $-3,77$ & & $-1,72$ & 14,39 \\
\hline nov-10 & $-0,34$ & $-0,25$ & 1,74 & $-0,23$ & & & 0,52 & 6,63 & 4,38 & $-0,17$ & 0,31 & 8,61 & & $-3,68$ & $-2,88$ \\
\hline dez-10 & $-2,64$ & $-5,24$ & $-1,70$ & $-3,60$ & & & $-0,73$ & $-3,44$ & $-13,95$ & $-5,79$ & $-6,84$ & 2,35 & & $-0,28$ & $-9,03$ \\
\hline jan-11 & 1,78 & 1,83 & 0,88 & 1,36 & & & $-1,98$ & 6,24 & $-3,35$ & $-0,76$ & 0,13 & $-18,37$ & & 4,58 & $-1,17$ \\
\hline fev-11 & $-4,79$ & $-4,50$ & $-1,04$ & $-2,57$ & & & $-2,66$ & $-8,71$ & $-9,42$ & $-2,39$ & $-5,11$ & 0,25 & & $-7,53$ & $-12,88$ \\
\hline mar-11 & 1,04 & 2,79 & $-1,72$ & $-1,05$ & & & 5,24 & 0,09 & $-5,09$ & 3,06 & $-1,84$ & 2,15 & & 3,15 & $-0,07$ \\
\hline abr-11 & 0,31 & 5,75 & 0,49 & $-0,09$ & & 14,13 & 6,27 & 2,50 & 3,40 & 6,05 & 1,58 & 3,47 & & 1,23 & $-8,00$ \\
\hline mai-11 & $-5,63$ & $-4,20$ & $-1,50$ & $-6,99$ & & 13,35 & $-3,28$ & $-9,00$ & 6,05 & $-3,47$ & $-3,13$ & $-1,60$ & & 1,89 & $-9,07$ \\
\hline jun-11 & $-2,27$ & $-0,53$ & $-0,30$ & $-2,69$ & & & $-2,49$ & $-1,29$ & $-10,67$ & 0,26 & $-1,74$ & $-0,85$ & 0,00 & $-0,65$ & $-1,04$ \\
\hline jul-11 & $-3,04$ & $-5,36$ & $-1,08$ & $-1,45$ & & & $-2,84$ & 2,96 & $-8,73$ & $-2,73$ & $-2,50$ & $-0,74$ & & 5,79 & $-6,56$ \\
\hline ago-11 & $-11,55$ & $-15,87$ & $-3,37$ & $-8,99$ & & & 3,47 & $-2,18$ & $-5,52$ & $-9,76$ & $-5,31$ & 2,21 & & 2,61 & $-10,04$ \\
\hline set-11 & 2,85 & 5,69 & $-1,12$ & $-2,03$ & & 19,30 & 9,63 & $-0,08$ & & 2,99 & 3,97 & 1,84 & & 2,60 & 4,09 \\
\hline out-11 & $-1,33$ & 5,85 & $-3,88$ & $-4,79$ & & & $-7,19$ & $-1,19$ & & 1,09 & $-5,94$ & $-1,84$ & & $-2,20$ & $-4,42$ \\
\hline
\end{tabular}




\begin{tabular}{|c|c|c|c|c|c|c|c|c|c|c|c|c|c|c|c|}
\hline$\stackrel{\leftrightarrow \mathscr{e}}{\sum}$ & 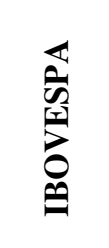 & 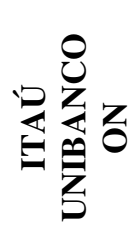 & $\begin{array}{l}z \\
0 \\
z \\
z \\
\vdots \\
\vdots \\
\vdots\end{array}$ & 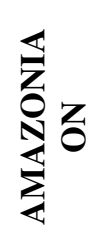 & 资 & 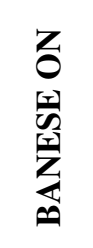 & 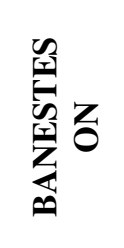 & 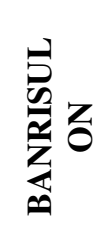 & $\begin{array}{l}0 \\
\sum_{1} \\
0 \\
0 \\
0 \\
0\end{array}$ & 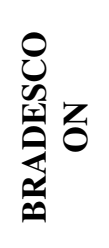 & $\begin{array}{l}z \\
0 \\
0 \\
\frac{1}{n} \\
\frac{\pi}{x}\end{array}$ & $\begin{array}{l}z \\
0 \\
0 \hat{z} \\
0\end{array}$ & 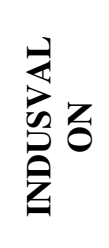 & 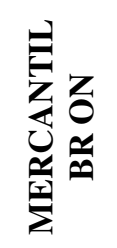 & 兴 \\
\hline nov-11 & 4,34 & $-0,51$ & $-2,44$ & 1,91 & & & 6,20 & 7,35 & 0,97 & 2,56 & 1,33 & 0,26 & & $-1,11$ & $-2,23$ \\
\hline dez-11 & 0,55 & 4,92 & $-10,84$ & $-1,90$ & & & 2,83 & 8,56 & 12,21 & 4,11 & $-2,43$ & $-0,26$ & & $-2,74$ & 7,19 \\
\hline jan-12 & 5,57 & 6,38 & $-2,29$ & $-1,35$ & & & 21,36 & 3,52 & 9,02 & 5,26 & 6,61 & 2,68 & & $-0,05$ & 5,77 \\
\hline fev-12 & 7,59 & 5,01 & $-3,12$ & 9,16 & & 9,19 & $-3,27$ & 4,10 & $-17,69$ & $-0,21$ & 8,86 & 0,97 & & 5,72 & 13,76 \\
\hline mar-12 & 1,71 & 3,33 & $-1,80$ & 4,49 & & 5,82 & 4,18 & 2,91 & $-1,03$ & 6,23 & 3,08 & $-3,65$ & & 7,26 & 2,02 \\
\hline abr-12 & $-6,25$ & $-12,18$ & 0,51 & $-1,74$ & & & $-4,91$ & 0,26 & $-0,65$ & $-5,95$ & $-14,44$ & 0,76 & & 0,29 & $-11,30$ \\
\hline mai-12 & $-9,10$ & $-9,57$ & 2,07 & $-6,23$ & & & $-9,94$ & & $-5,88$ & $-7,02$ & $-12,28$ & $-0,76$ & & $-10,43$ & $-0,91$ \\
\hline jun-12 & $-4,42$ & $-0,54$ & $-7,84$ & $-3,91$ & & & $-1,31$ & & $-7,75$ & 3,03 & $-8,39$ & & & 5,58 & 1,32 \\
\hline jul-12 & $-0,09$ & 3,54 & 5,48 & $-4,11$ & & & 13,21 & $-5,04$ & 0,00 & 1,13 & 2,30 & & & 4,05 & $-7,03$ \\
\hline ago-12 & 6,37 & 10,19 & $-0,43$ & 9,52 & & & $-10,37$ & 13,28 & 0,00 & 9,35 & 16,99 & & & 6,16 & 9,69 \\
\hline set-12 & 3,13 & 0,03 & 10,66 & 6,03 & & 0,00 & $-23,04$ & 5,86 & 1,78 & 1,16 & 10,07 & 2,69 & & $-0,36$ & 5,91 \\
\hline out-12 & $-2,47$ & $-7,11$ & $-4,36$ & $-2,83$ & & & $-9,07$ & $-10,71$ & 0,53 & $-4,61$ & $-10,29$ & 0,00 & & $-5,66$ & $-13,35$ \\
\hline nov-12 & $-2,36$ & 3,83 & 0,01 & $-2,26$ & & & 0,50 & $-5,24$ & 0,18 & 9,54 & $-5,42$ & 0,00 & & $-0,86$ & $-4,64$ \\
\hline dez-12 & 4,04 & 8,12 & 1,98 & $-5,31$ & & & $-0,35$ & $-0,38$ & 0,00 & 15,85 & 8,69 & & & $-1,08$ & 3,05 \\
\hline jan-13 & 3,22 & 12,00 & $-0,06$ & 1,06 & & & 9,09 & 5,59 & & 7,16 & 10,82 & & & 1,19 & 6,50 \\
\hline fev-13 & $-6,13$ & $-1,02$ & 2,85 & $-0,69$ & & & $-1,32$ & 16,92 & & $-2,61$ & $-5,26$ & & & 2,50 & $-9,22$ \\
\hline mar-13 & $-1,88$ & 6,83 & 12,07 & $-1,14$ & & & $-1,31$ & 4,54 & 0,00 & 4,49 & 9,61 & & & 3,39 & 6,57 \\
\hline abr-13 & $-3,66$ & $-4,38$ & $-1,67$ & 2,36 & & & $-0,68$ & $-6,36$ & $-1,61$ & 3,35 & 1,37 & & & 1,52 & $-6,71$ \\
\hline mai-13 & 1,27 & 2,64 & $-0,12$ & $-0,72$ & & & $-1,31$ & $-2,70$ & $-2,62$ & 0,36 & $-4,54$ & & & $-0,74$ & 4,65 \\
\hline jun-13 & $-11,15$ & $-5,20$ & 2,74 & $-4,31$ & & & $-2,33$ & $-9,06$ & $-3,22$ & $-8,47$ & $-11,08$ & & & $-5,06$ & $-2,57$ \\
\hline jul-13 & $-5,05$ & $-6,37$ & $-2,97$ & 1,02 & & & $-3,28$ & $-3,28$ & & $-2,10$ & $-3,70$ & & 0,00 & 5,85 & $-7,06$ \\
\hline ago-13 & 5,97 & 2,92 & $-2,53$ & $-0,56$ & & & $-1,12$ & 0,71 & & 0,27 & 3,87 & & & 3,35 & $-0,36$ \\
\hline set-13 & 6,89 & 4,08 & 0,25 & $-1,76$ & & & 4,66 & 7,75 & & 10,10 & 12,77 & 0,32 & & $-4,99$ & 4,39 \\
\hline out-13 & 1,00 & 3,52 & 4,01 & 0,35 & & & 2,67 & 2,10 & 38,22 & 4,95 & 11,11 & 0,07 & & 0,28 & 10,77 \\
\hline nov-13 & $-2,54$ & 0,74 & 0,31 & $-0,42$ & & & $-0,33$ & $-5,28$ & 11,62 & $-4,33$ & $-2,14$ & & & $-0,97$ & $-0,02$ \\
\hline dez-13 & $-3,91$ & $-5,81$ & 2,84 & $-2,42$ & & & $-1,88$ & $-5,53$ & 3,70 & $-8,12$ & $-8,88$ & & & $-14,96$ & $-5,51$ \\
\hline jan-14 & $-3,31$ & $-3,93$ & $-1,80$ & $-0,34$ & & & $-3,98$ & $-3,12$ & & $-5,75$ & $-8,05$ & & & $-6,64$ & $-3,01$ \\
\hline fev-14 & $-3,67$ & 4,01 & 0,31 & $-3,85$ & & & $-2,27$ & & & $-2,92$ & $-7,78$ & $-0,30$ & & $-1,57$ & $-6,67$ \\
\hline mar-14 & $-0,68$ & 4,08 & $-8,14$ & 0,08 & & & $-2,34$ & & 4,05 & 4,73 & 0,16 & 2,94 & & $-4,16$ & 2,00 \\
\hline
\end{tabular}




\begin{tabular}{|c|c|c|c|c|c|c|c|c|c|c|c|c|c|c|c|}
\hline$\stackrel{\Theta}{\sum}$ & 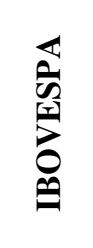 & 是首号 & $\begin{array}{l}z \\
0 \\
z \\
z \\
4 \\
\text { 至 }\end{array}$ & 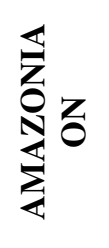 & 资 & 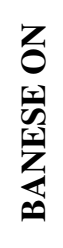 & 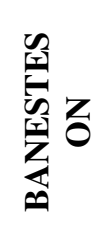 & $\frac{3}{\underbrace{}_{0}}$ & 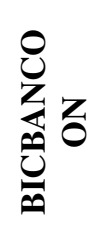 & 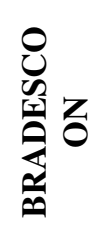 & $\begin{array}{l}Z \\
0 \\
\vdots \\
\frac{1}{0} \\
\frac{\pi}{\infty}\end{array}$ & 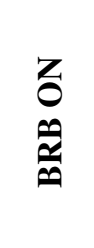 & 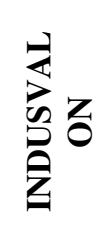 & 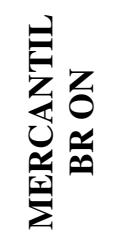 & 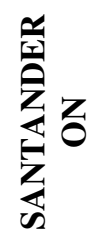 \\
\hline abr-14 & 8,99 & 11,03 & $-1,59$ & 6,22 & & & 0,43 & 2,15 & 2,70 & 13,72 & 15,45 & & & $-7,72$ & 7,07 \\
\hline mai-14 & 3,16 & 2,59 & 4,61 & $-4,22$ & & & $-1,86$ & $-5,62$ & & 1,59 & $-0,33$ & & & 11,13 & 13,58 \\
\hline jun-14 & 1,00 & $-1,77$ & 1,41 & 0,21 & & & $-2,42$ & 6,33 & & $-3,31$ & 7,29 & 0,00 & & $-19,28$ & 6,49 \\
\hline jul-14 & 3,90 & 5,05 & 1,34 & $-0,59$ & & & 4,68 & 3,74 & 0,52 & 4,15 & 8,65 & & & $-5,82$ & $-0,43$ \\
\hline ago-14 & 3,45 & 8,38 & 1,62 & 0,36 & & & 7,47 & 1,32 & $-2,63$ & 6,79 & 8,36 & & $-1,52$ & 13,02 & 0,83 \\
\hline set-14 & 0,91 & $-0,21$ & $-1,97$ & $-0,33$ & & & 7,07 & 11,51 & 0,00 & 2,38 & 8,62 & & 4,44 & $-20,02$ & 3,59 \\
\hline out-14 & $-6,99$ & $-8,53$ & $-1,41$ & $-4,61$ & & & $-6,61$ & $-6,69$ & & $-7,96$ & $-10,66$ & & 0,00 & $-18,24$ & $-5,92$ \\
\hline nov-14 & $-1,42$ & 4,44 & $-3,10$ & $-2,44$ & & & $-12,72$ & 9,61 & & 2,82 & $-5,80$ & & & $-16,00$ & 0,92 \\
\hline dez-14 & $-6,90$ & $-3,91$ & $-4,00$ & $-3,82$ & & & $-3,13$ & $-9,97$ & & $-3,82$ & $-7,84$ & & & 2,95 & $-6,77$ \\
\hline
\end{tabular}

Fonte: Economática 


\section{APÊNDICE 5 - Estimação do beta dos bancos brasileiros}

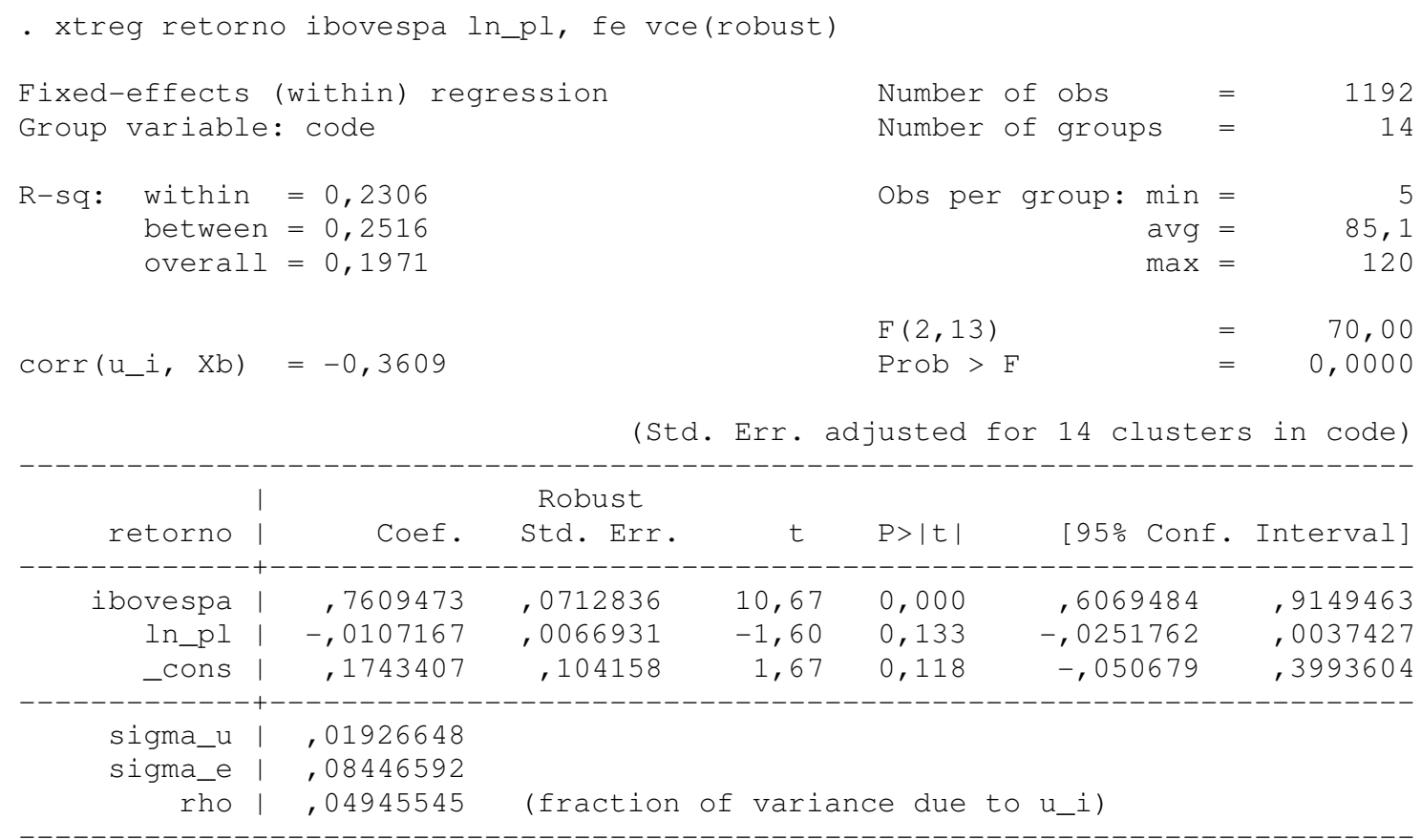

- xtreg retorno ibovespa, fe

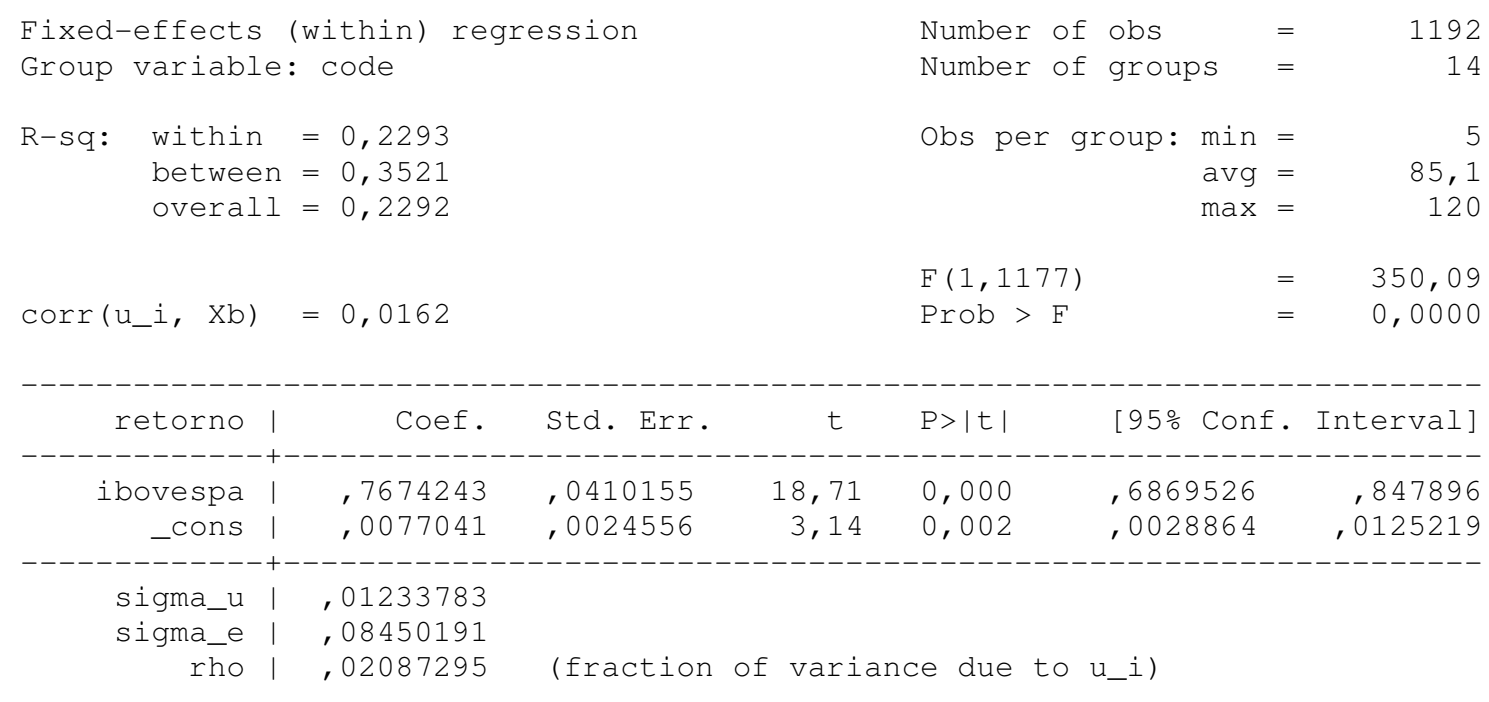


- predict residuo, e

(1448 missing values generated)

One-sample $t$ test

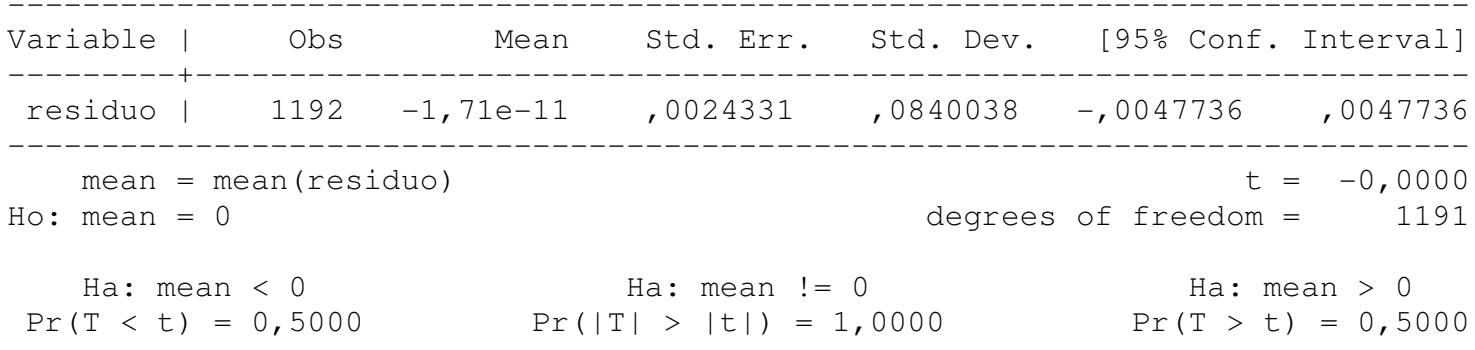

- ttest residuo $==0$

- sfrancia residuo

Shapiro-Francia $W^{\prime}$ test for normal data

\begin{tabular}{|c|c|c|c|c|c|}
\hline Variable | & Obs & $W^{\prime}$ & $V^{\prime}$ & z & Prob>z \\
\hline residuo | & 1192 & 0,86643 & 102,919 & 8,721 & 0,00001 \\
\hline
\end{tabular}




\section{APÊNDICE 6 - Estimação do beta Ibovespa / S\&P 500}

- regress ibovespa sp500

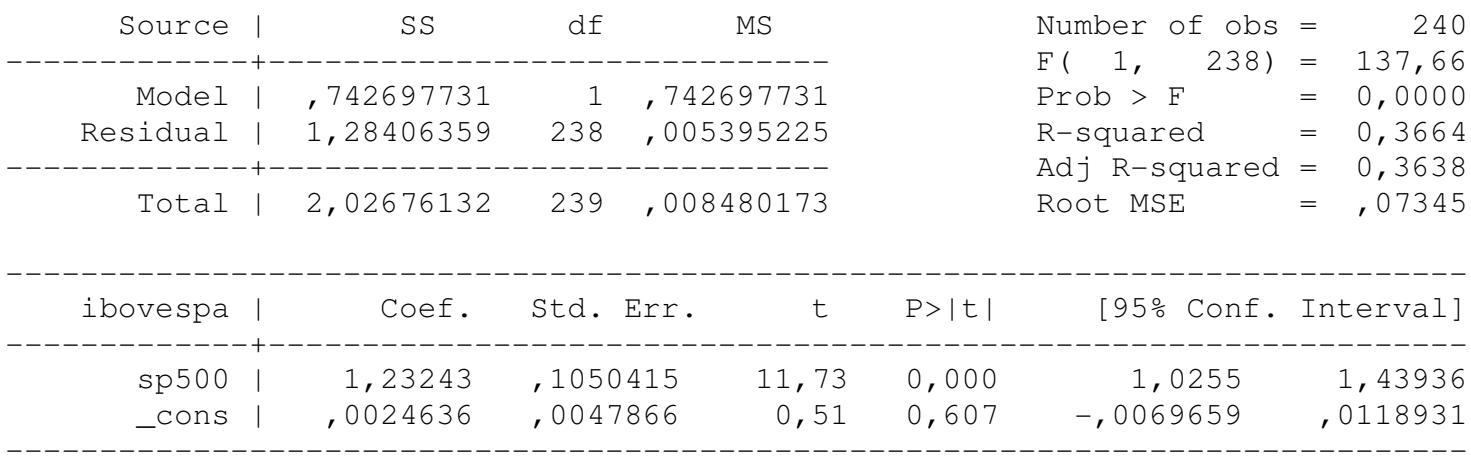

- predict residuo, residuals

- estat hettest

Breusch-Pagan / Cook-Weisberg test for heteroskedasticity

Ho: Constant variance

Variables: fitted values of ibovespa

$\operatorname{chi2}(1) \quad=\quad 7,05$

Prob $>$ chi2 $=0,0079$

- estat ovtest

Ramsey RESET test using powers of the fitted values of ibovespa

Ho: model has no omitted variables

$$
\begin{aligned}
& \mathrm{F}(3,235)=0,29 \\
& \text { Prob }>\mathrm{F}=0,8321
\end{aligned}
$$

- test residuo $==0$

One-sample $t$ test

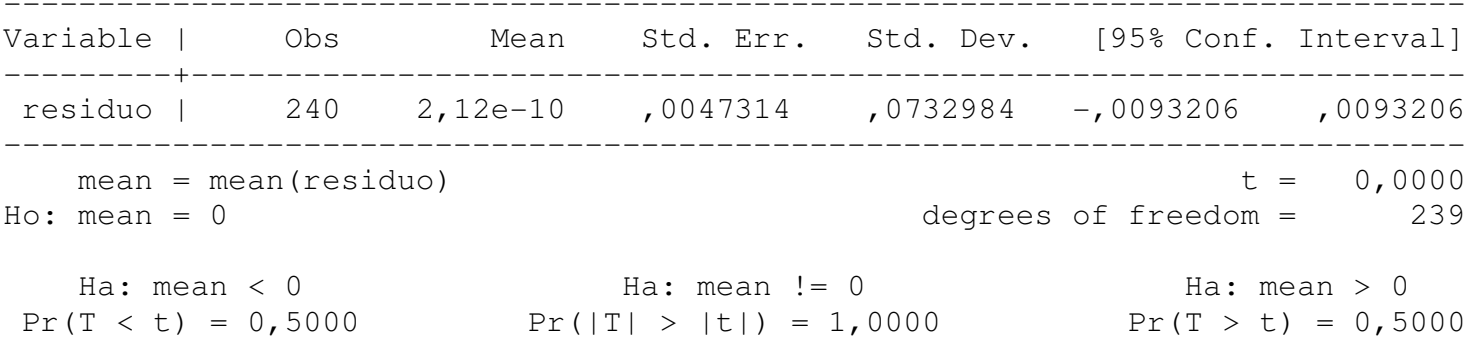


- sfrancia residuo

Shapiro-Francia $W^{\prime}$ test for normal data

\begin{tabular}{|c|c|c|c|c|c|}
\hline Variable | & Obs & $W^{\prime}$ & $V^{\prime}$ & $\mathrm{z}$ & Prob>z \\
\hline residuo | & 240 & 0,96181 & 7,180 & 4,096 & 0,00002 \\
\hline
\end{tabular}

- regress ibovespa sp500, vce(robust)

Linear regression

$\begin{array}{lr}\text { Number of obs } & =240 \\ \text { F 1, 238) } & 85,55 \\ \text { Prob }>\text { F } & =0,0000 \\ \text { R-squared } & =0,3664 \\ \text { Root MSE } & =, 07345\end{array}$

\begin{tabular}{|c|c|c|c|c|c|c|}
\hline & & Robust & & & & \\
\hline ibovespa & Coef. & Std. Err. & t & $P>|t|$ & [95\% Conf. & Interval] \\
\hline $\operatorname{sp} 500$ & 1,23243 &, 1332425 & 9,25 & 0,000 &, 9699446 & 1,494915 \\
\hline _cons &, 0024636 &, 0049683 & 0,50 & 0,620 &,- 0073238 &, 012251 \\
\hline
\end{tabular}




\section{APÊNDICE 7 - Regressões determinantes do ROE}

log: C: \Users $\backslash$ Fernando \Google Drive \Doutorado\Tese $\backslash$ Econometrics $\backslash$ saida_m

$>$ acro.smcl

log type: smcl

opened on: 29 Jan 2016, 01:58:55

$\cdot \cdot$

- reg roe ln_pl alavanc alavanc2 sem1-sem9 if tipo==1\&filtro==1, vce(robust)

Linear regression

$\begin{array}{llr}\text { Number of obs } & = & 895 \\ \mathrm{~F}(12, \quad 882) & =14,79 \\ \text { Prob }>\mathrm{F} & =0,0000 \\ \text { R-squared } & =0,2055 \\ \text { Root MSE } & =, 16469\end{array}$

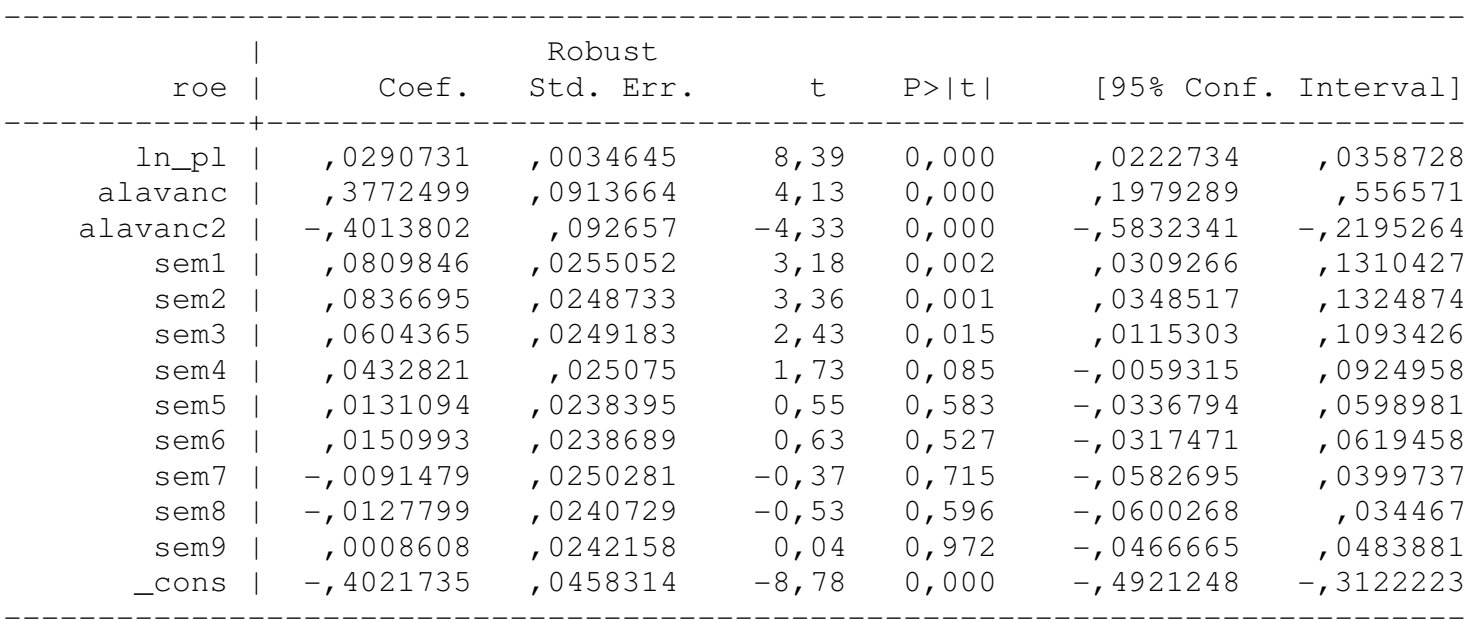

- reg roe ln_pl alavanc alavanc2 seml-sem9 if tipo==2\&filtro==1, vce(robust)

Linear regression

$\begin{array}{llr}\text { Number of obs } & = & 307 \\ \text { F (12, 294) } & 4,11 \\ \text { Prob }>\text { F } & =0,0000 \\ \text { R-squared } & =, 1212 \\ \text { Root MSE } & =, 15388\end{array}$

\begin{tabular}{|c|c|c|c|c|c|c|c|}
\hline & I & & Robust & & & & \\
\hline roe & | & Coef. & Std. Err. & t & $P>|t|$ & [95\% Conf. & Interval] \\
\hline ln_pl & I &, 0184237 &, 009928 & 1,86 & 0,064 &,- 0011153 &, 0379627 \\
\hline alavanc & | &, 3252354 &, 1927597 & 1,69 & 0,093 &,- 0541284 &, 7045992 \\
\hline alavanc2 & | &,- 3451192 & , 1789111 & $-1,93$ & 0,055 &,- 697228 &, 0069897 \\
\hline sem 1 & I &, 0021744 &, 0405873 & 0,05 & 0,957 &,- 0777041 &, 0820529 \\
\hline sem2 & | &, 1124446 &, 0552762 & 2,03 & 0,043 &, 0036575 &, 2212317 \\
\hline sem3 & | &, 0245793 &, 0290703 & 0,85 & 0,399 &,- 032633 &, 0817915 \\
\hline sem 4 & | &, 0570765 &, 0387657 & 1,47 & 0,142 &,- 019217 &, 1333699 \\
\hline sem5 & | &,- 0559265 &, 0367897 & $-1,52$ & 0,130 &,- 128331 &, 0164781 \\
\hline sem6 & | &,- 0061535 &, 0304771 & $-0,20$ & 0,840 &,- 0661345 &, 0538275 \\
\hline sem 7 & | &,- 0671285 &, 0312027 & $-2,15$ & 0,032 &,- 1285375 &,- 0057196 \\
\hline sem 8 & | &,- 0234444 &, 0347442 & $-0,67$ & 0,500 &,- 0918233 &, 0449345 \\
\hline sem 9 & | &,- 0123835 &, 0282007 & $-0,44$ & 0,661 &,- 0678844 &, 0431174 \\
\hline _cons & I &,- 1982939 &, 1235701 & $-1,60$ & 0,110 &,- 4414879 &, 0449002 \\
\hline
\end{tabular}


- reg roe ln_pl alavanc alavanc2 sem1-sem9 if tipo==3\&filtro==1, vce(robust)

Linear regression

$\begin{array}{lrr}\text { Number of obs } & = & 243 \\ \text { F 9, 233) } & =13,94 \\ \text { Prob }>\text { F } & =0,0000 \\ \text { R-squared } & =0,1586 \\ \text { Root MSE } & =, 2729\end{array}$

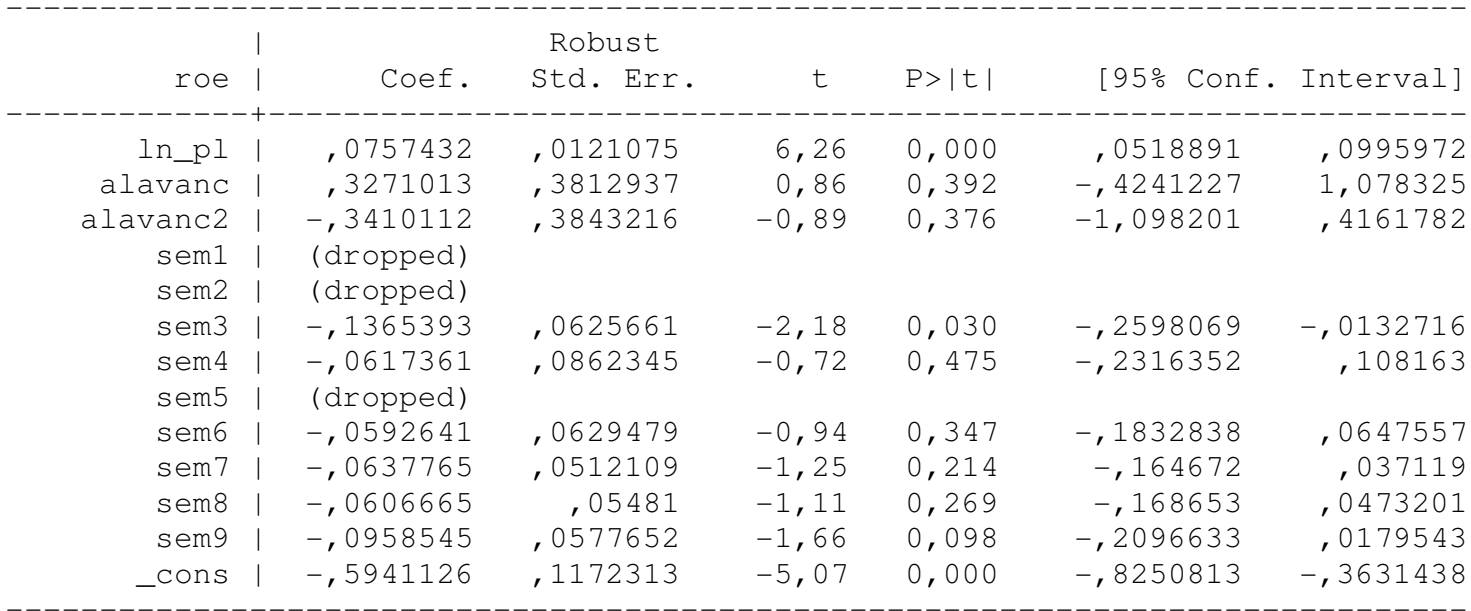

- reg roe ln_pl alavanc alavanc2 seml-sem9 if tipo==4\&filtro==1, vce(robust)

Linear regression

$\begin{array}{llr}\text { Number of obs } & = & 34 \\ \text { F 9, 24) } & 1,72 \\ \text { Prob }>\text { F } & =0,1380 \\ \text { R-squared } & =0,5389 \\ \text { Root MSE } & =, 21262\end{array}$

\begin{tabular}{|c|c|c|c|c|c|c|c|}
\hline & I & & Robust & & & & \\
\hline roe & i & Coef. & Std. Err. & t & $P>|t|$ & [95\% Conf. & Interval] \\
\hline ln_pl & I &, 1372805 &, 0994024 & 1,38 & 0,180 &,- 0678761 &, 3424371 \\
\hline alavanc & i &,- 0081237 &, 9332578 & $-0,01$ & 0,993 & $-1,934273$ & 1,918026 \\
\hline alavanc2 & i &,- 5687423 & 1,088264 & $-0,52$ & 0,606 & $-2,814809$ & 1,677324 \\
\hline sem 1 & I & (dropped) & & & & & \\
\hline sem2 & I & (dropped) & & & & & \\
\hline sem3 & | &, 0102506 &, 0814596 & 0,13 & 0,901 &,- 1578737 &, 178375 \\
\hline sem 4 & | &, 0362575 &, 1449184 & 0,25 & 0,805 &,- 2628394 &, 3353544 \\
\hline sem5 & I & (dropped) & & & & & \\
\hline sem6 & । &, 5660538 &, 1917796 & 2,95 & 0,007 &, 1702403 &, 9618674 \\
\hline sem 7 & | &, 1042668 &, 1281936 & 0,81 & 0,424 &,- 1603117 &, 3688453 \\
\hline sem 8 & | &, 1286879 & , 1189107 & 1,08 & 0,290 &,- 1167318 &, 3741076 \\
\hline sem 9 & | &,- 0058987 &, 1149876 & $-0,05$ & 0,960 &,- 2432214 &, 2314239 \\
\hline _cons & I & $-1,274023$ &, 9369375 & $-1,36$ & 0,187 & $-3,207767$ &, 6597208 \\
\hline
\end{tabular}


- xtreg roe ln_pl alavanc alavanc2 sem1-sem9 if tipo==1\&filtro==1, fe vce(robust)

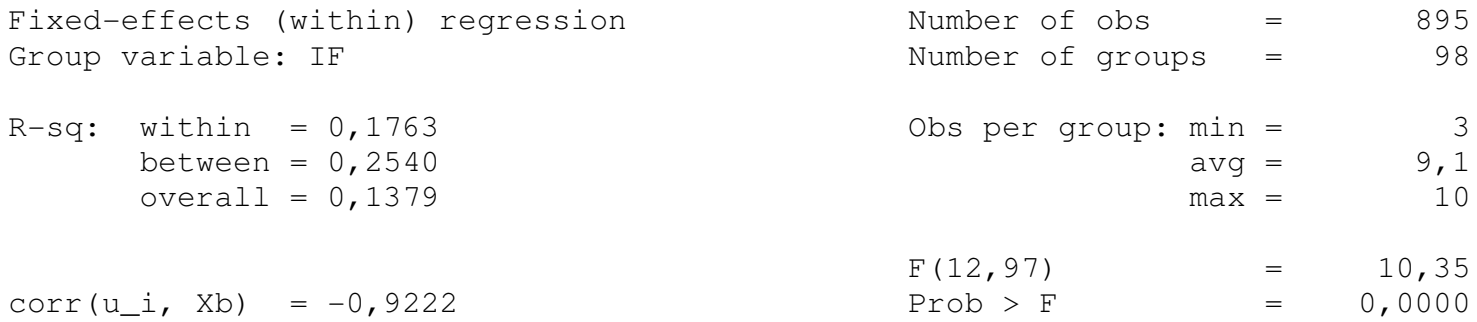

(Std. Err. adjusted for 98 clusters in IF)

\begin{tabular}{|c|c|c|c|c|c|c|c|}
\hline & | & & Robust & & & & \\
\hline roe & I & Coef. & Std. Err. & t & $P>|t|$ & [95\% Conf. & Interval] \\
\hline ln_pl & I &, 1730897 &, 0368277 & 4,70 & 0,000 & , 0999968 &, 2461826 \\
\hline alavanc & | &, 1338567 &, 1509246 & 0,89 & 0,377 &,- 165687 &, 4334003 \\
\hline alavanc2 & | &,- 2229153 &, 0926066 & $-2,41$ & 0,018 &,- 4067137 &,- 0391168 \\
\hline sem 1 & | &, 0796219 &, 0271242 & 2,94 & 0,004 &, 0257879 &, 133456 \\
\hline sem2 & | &, 0819398 &, 0249692 & 3,28 & 0,001 &, 0323828 &, 1314969 \\
\hline sem 3 & | &, 0541997 &, 0243733 & 2,22 & 0,028 &, 0058255 &, 1025738 \\
\hline sem 4 & | &, 0388671 &, 0253772 & 1,53 & 0,129 &,- 0114997 &, 0892339 \\
\hline sem5 & | &, 0061328 &, 0228548 & 0,27 & 0,789 &,- 0392277 &, 0514934 \\
\hline sem6 & i &, 0079865 &, 0199262 & 0,40 & 0,689 &,- 0315615 &, 0475345 \\
\hline sem 7 & | &,- 0153647 &, 0200405 & $-0,77$ & 0,445 &,- 0551396 &, 0244102 \\
\hline sem 8 & | &,- 0204123 &, 0203125 & $-1,00$ & 0,317 &,- 0607271 & , 0199024 \\
\hline sem 9 & I &,- 0036759 &, 0200635 & $-0,18$ & 0,855 &,- 0434963 &, 0361446 \\
\hline _cons & I & $-2,236197$ &, 4640903 & $-4,82$ & 0,000 & $-3,157288$ & $-1,315107$ \\
\hline sigma_u & | &, 28676816 & & & & & \\
\hline sigma_e & | &, 13574864 & & & & & \\
\hline rho & | &, 81693801 & (fraction & $=$ vari & e due & u_i) & \\
\hline
\end{tabular}




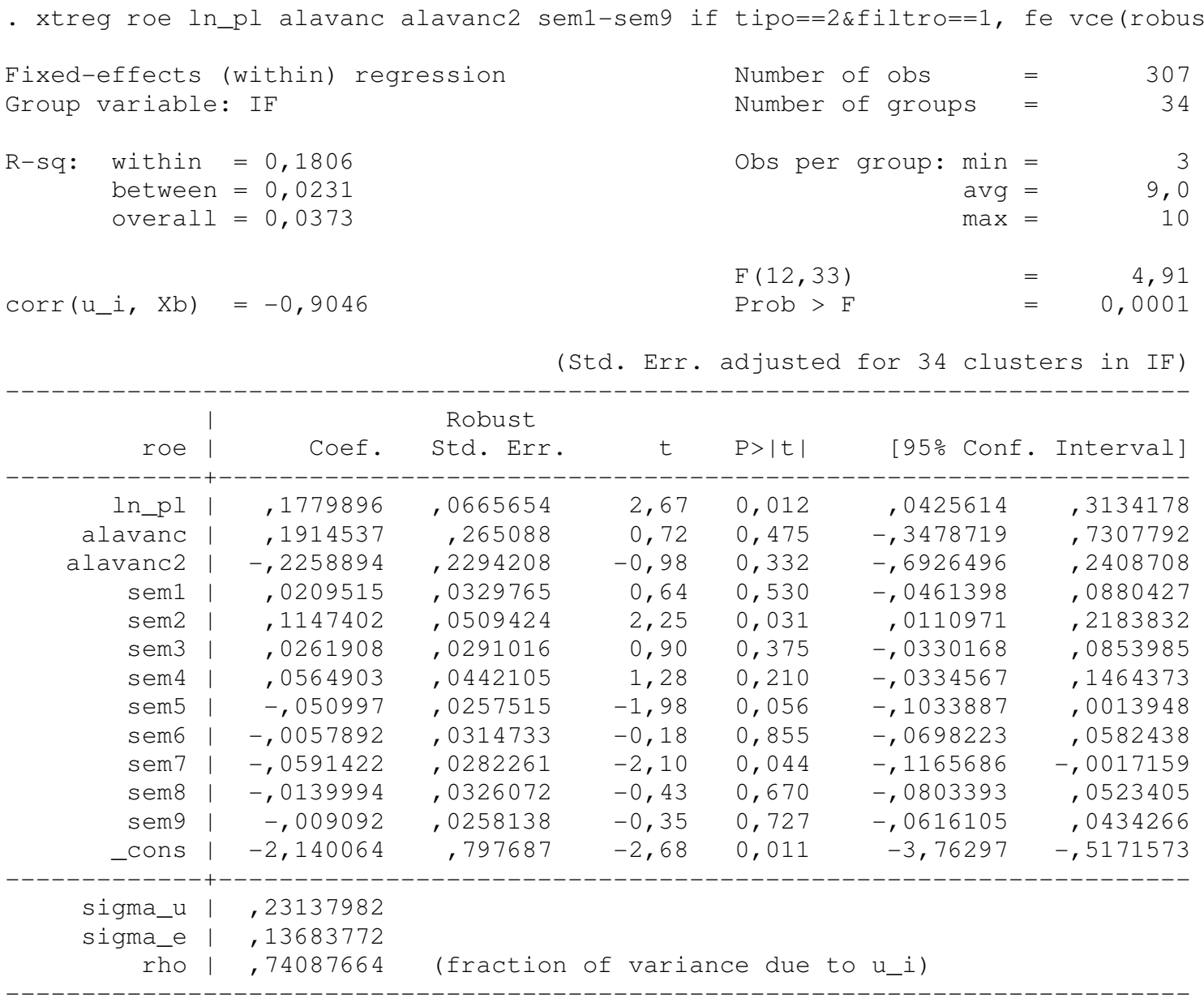


- xtreg roe ln_pl alavanc alavanc2 sem1-sem9 if tipo==3\&filtro==1, fe vce(robust)

Fixed-effects (within) regression Group variable: IF

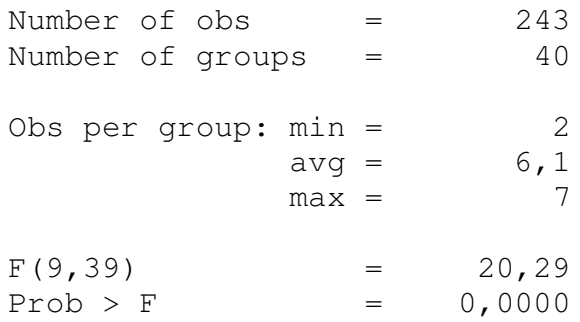

$\operatorname{corr}\left(u_{i} i, \mathrm{Xb}\right)=-0,5491$

(Std. Err. adjusted for 40 clusters in IF)

\begin{tabular}{|c|c|c|c|c|c|c|c|}
\hline \multicolumn{8}{|c|}{ Robust } \\
\hline roe & । & Coef. & Std. Err. & t & $P>|t|$ & [95\% Conf. & Interval] \\
\hline ln_pl & | &, 1304835 &, 1057494 & 1,23 & 0,225 &,- 0834148 &, 3443817 \\
\hline alavanc & 1 &, 8970349 &, 6068583 & 1,48 & 0,147 &,- 3304519 & 2,124522 \\
\hline alavanc2 & i & $-1,087249$ &, 340269 & $-3,20$ & 0,003 & $-1,775508$ &,- 3989895 \\
\hline sem 1 & i & (dropped) & & & & & \\
\hline sem2 & i & (dropped) & & & & & \\
\hline sem3 & | &,- 1340927 &, 0865827 & $-1,55$ & 0,130 &,- 3092227 &, 0410373 \\
\hline sem 4 & i &,- 016262 &, 0832182 & $-0,20$ & 0,846 &,- 1845868 &, 1520628 \\
\hline sem5 & i & (dropped) & & & & & \\
\hline sem6 & i &,- 0457372 &, 0730252 & $-0,63$ & 0,535 &,- 1934446 &, 1019702 \\
\hline sem 7 & i &,- 0438534 &, 0568386 & $-0,77$ & 0,445 &,- 1588202 &, 0711135 \\
\hline sem 8 & i &,- 0509011 &, 0735917 & $-0,69$ & 0,493 &,- 1997543 &, 0979521 \\
\hline sem 9 & 1 &,- 0810559 &, 0667459 & $-1,21$ & 0,232 &,- 2160621 &, 0539504 \\
\hline _cons & i & $-1,2171$ & 1,265638 & $-0,96$ & 0,342 & $-3,777095$ & 1,342895 \\
\hline sigma_u & i &, 21252105 & & & & & \\
\hline sigma_e & 1 &, 23858462 & & & & & \\
\hline rho & 1 &, 44241515 & (fraction & f varia & ce due & u_i) & \\
\hline
\end{tabular}




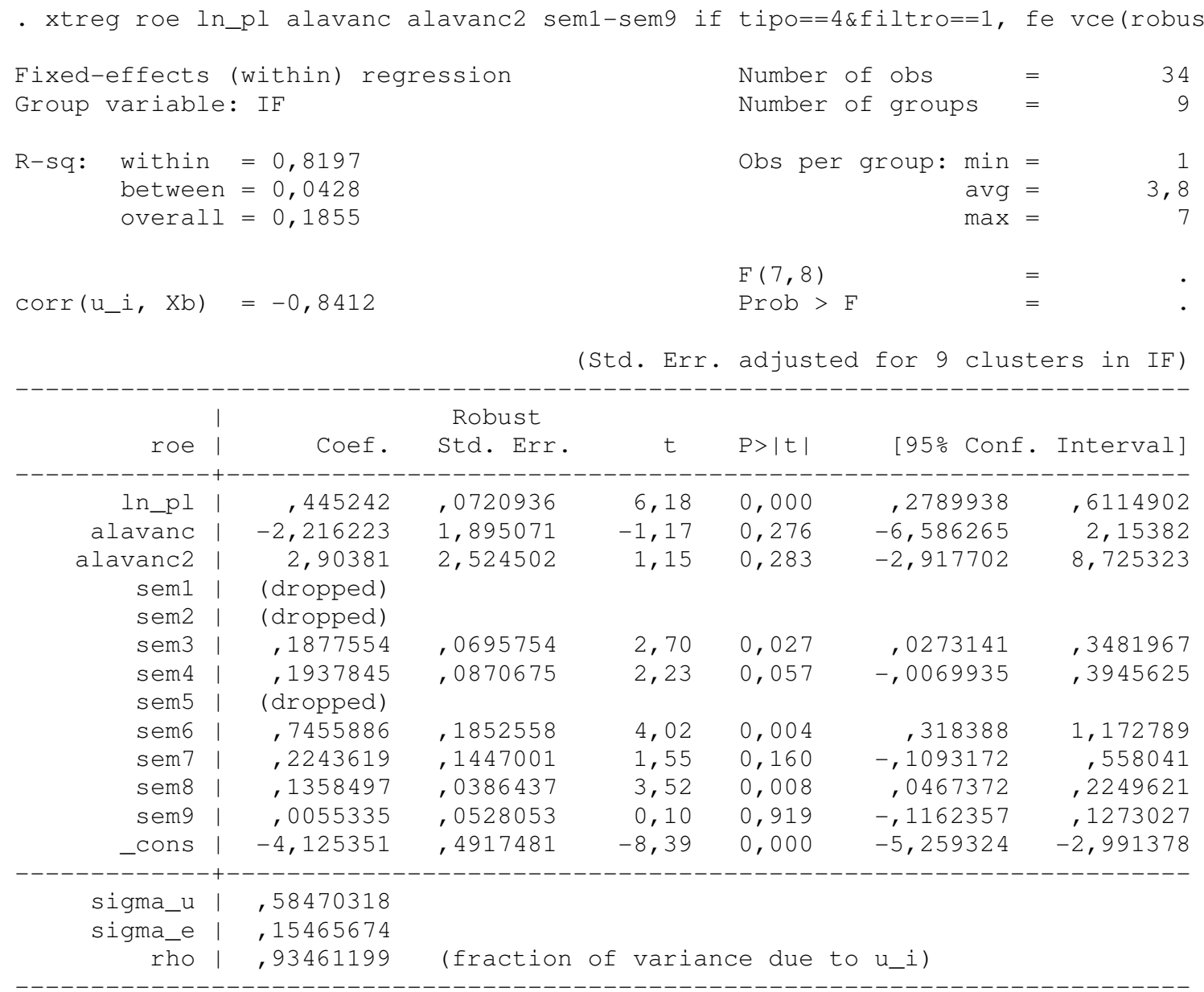


- xtreg roe ln_pl alavanc alavanc2 sem1-sem9 if tipo==1\&filtro==1, re vce(robust)

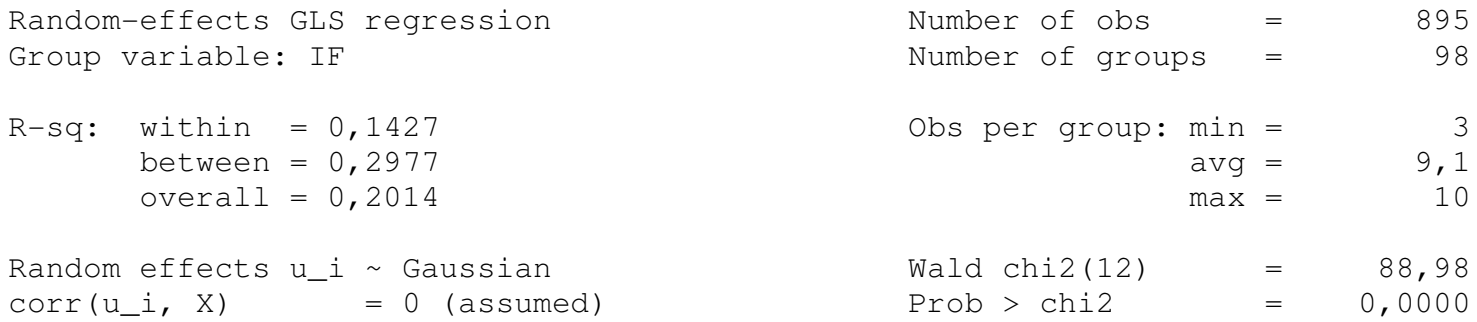

(Std. Err. adjusted for clustering on IF)

\begin{tabular}{|c|c|c|c|c|c|c|c|}
\hline & I & & Robust & & & & \\
\hline roe & i & Coef. & Std. Err. & z & $P>|z|$ & [95\% Conf. & Interval] \\
\hline ln_pl & I &, 0365049 &, 0064799 & 5,63 & 0,000 &, 0238045 &, 0492052 \\
\hline alavanc & | &, 2871192 &, 1120072 & 2,56 & 0,010 &, 0675891 &, 5066493 \\
\hline alavanc2 & | &,- 3453004 & 1052649 & $-3,28$ & 0,001 &,- 5516158 &,- 138985 \\
\hline sem 1 & | &, 0777078 &, 0236874 & 3,28 & 0,001 &, 0312813 &, 1241343 \\
\hline sem2 & | &, 0809619 &, 0233694 & 3,46 & 0,001 &, 0351587 &, 1267651 \\
\hline sem3 & | &, 0568914 &, 0215658 & 2,64 & 0,008 &, 0146233 &, 0991595 \\
\hline sem 4 & | &, 0435971 &, 0219731 & 1,98 & 0,047 &, 0005306 &, 0866636 \\
\hline sem5 & | &, 0134604 &, 0203784 & 0,66 & 0,509 &,- 0264805 &, 0534013 \\
\hline sem 6 & | &, 013747 & , 0199817 & 0,69 & 0,491 &,- 0254164 &, 0529104 \\
\hline sem 7 & | &,- 0112585 &, 021186 & $-0,53$ & 0,595 &,- 0527823 &, 0302653 \\
\hline sem 8 & | &,- 0157204 &, 0209679 & $-0,75$ & 0,453 &,- 0568168 &, 0253759 \\
\hline sem9 & | &,- 0003969 &, 0212257 & $-0,02$ & 0,985 &,- 0419984 &, 0412046 \\
\hline _cons & I &,- 4717333 &, 0851366 & $-5,54$ & 0,000 &,- 638598 &,- 3048686 \\
\hline sigma_u & I &, 0890479 & & & & & \\
\hline sigma_e & I &, 13574864 & & & & & \\
\hline rho & | &, 30084844 & (fraction & Evari & ce due & u_i) & \\
\hline
\end{tabular}


- xtreg roe ln_pl alavanc alavanc2 sem1-sem9 if tipo==2\&filtro==1, re vce(robust)

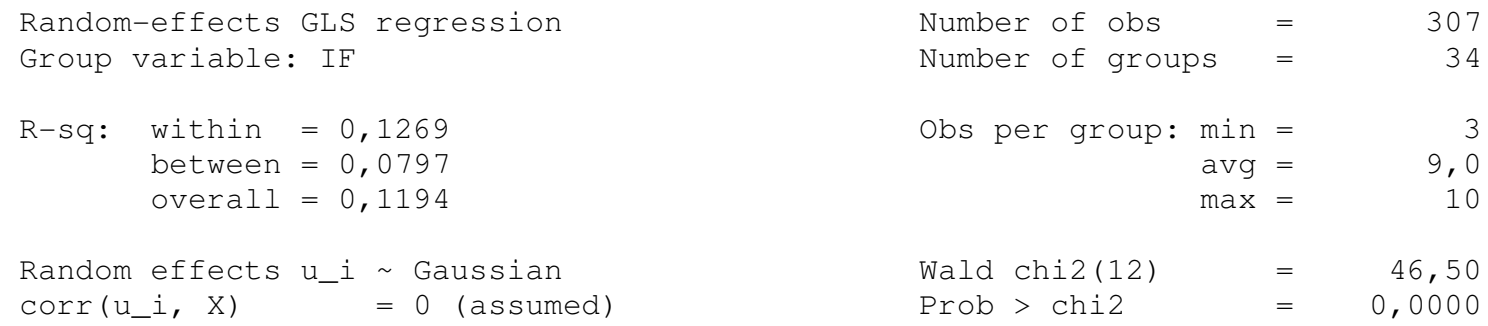

(Std. Err. adjusted for clustering on IF)

\begin{tabular}{|c|c|c|c|c|c|c|c|}
\hline & | & & Robust & & & & \\
\hline roe & | & Coef. & Std. Err. & $\mathrm{z}$ & $P>|z|$ & [95\% Conf. & Interval] \\
\hline ln_pl & | &, 0234688 &, 0120543 & 1,95 & 0,052 &,- 0001572 &, 0470948 \\
\hline alavanc & | &, 2724059 &, 2112517 & 1,29 & 0,197 &,- 1416399 &, 6864517 \\
\hline alavanc2 & | &,- 3157569 &, 1908141 & $-1,65$ & 0,098 &,- 6897457 &, 0582319 \\
\hline sem 1 & | &,- 0041761 &, 0378484 & $-0,11$ & 0,912 &,- 0783576 &, 0700054 \\
\hline sem2 & | &, 1056183 &, 052612 & 2,01 & 0,045 &, 0025006 &, 208736 \\
\hline sem3 & | & , 021914 &, 0267798 & 0,82 & 0,413 &,- 0305734 &, 0744015 \\
\hline sem 4 & | &, 055095 &, 037573 & 1,47 & 0,143 &,- 0185468 &, 1287368 \\
\hline sem5 & | &,- 0560549 &, 0338711 & $-1,65$ & 0,098 &,- 1224411 &, 0103313 \\
\hline sem6 & | &,- 0077573 &, 0282515 & $-0,27$ & 0,784 &,- 0631291 &, 0476146 \\
\hline sem 7 & | &,- 0673203 &, 0288794 & $-2,33$ & 0,020 &,- 1239229 &,- 0107176 \\
\hline sem8 & | &,- 022401 &, 0332455 & $-0,67$ & 0,500 &,- 0875611 &, 042759 \\
\hline sem9 & | &,- 0121896 &, 0265171 & $-0,46$ & 0,646 &,- 0641622 &, 0397829 \\
\hline _cons & | &,- 241175 &, 1509022 & $-1,60$ & 0,110 &,- 536938 &, 0545879 \\
\hline sigma_u & | &, 04075045 & & & & & \\
\hline sigma_e & | &, 13683772 & & & & & \\
\hline rho & | &, 08146119 & (fraction & f vari & e due & u_i) & \\
\hline
\end{tabular}


- xtreg roe ln_pl alavanc alavanc2 sem1-sem9 if tipo==3\&filtro==1, re vce(robust)

Random-effects GLS regression Group variable: IF

$\begin{aligned} \text { R-sq: } & \text { within }=0,1514 \\ \text { between } & =0,1530 \\ \text { overall } & =0,1518\end{aligned}$

Random effects u i Gaussian $\operatorname{corr}\left(u_{-} i, \mathrm{X}\right)=0$ (assumed)

$\begin{array}{llr}\text { Number of obs } & = & 243 \\ \text { Number of groups } & = & 40 \\ \text { Obs per group: } \min & = & 2 \\ \operatorname{avg} & = & 6,1 \\ \max & = & 7 \\ & & \\ \text { Wald chi2(9) } & = & \text {. } \\ \text { Prob }>\operatorname{chi} 2 & & =\end{array}$

(Std. Err. adjusted for clustering on IF)

\begin{tabular}{|c|c|c|c|c|c|c|c|}
\hline & I & & Robust & & & & \\
\hline roe & | & Coef. & Std. Err. & z & $P>|z|$ & [95\% Conf. & Interval] \\
\hline ln_pl & | & 0733823 &, 0170992 & 4,29 & 0,000 &, 0398685 &, 106896 \\
\hline alavanc & 1 &, 6749668 &, 3918882 & 1,72 & 0,085 &,- 0931199 & 1,443053 \\
\hline alavanc2 & i &,- 6947907 &, 3847387 & $-1,81$ & 0,071 & $-1,448865$ &, 0592833 \\
\hline sem 1 & I & (dropped) & & & & & \\
\hline sem2 & | & (dropped) & & & & & \\
\hline sem3 & | &,- 1371861 &, 0613574 & $-2,24$ & 0,025 &,- 2574444 &,- 0169279 \\
\hline sem 4 & | &,- 0471616 &, 0822077 & $-0,57$ & 0,566 &,- 2082856 &, 1139625 \\
\hline sem5 & 1 & (dropped) & & & & & \\
\hline sem 6 & | &,- 05576 &, 0591116 & $-0,94$ & 0,346 &,- 1716167 &, 0600967 \\
\hline sem 7 & | &,- 0602029 &, 0468927 & $-1,28$ & 0,199 &,- 1521109 &, 0317051 \\
\hline sem 8 & | &,- 056855 &, 0512822 & $-1,11$ & 0,268 &,- 1573663 &, 0436564 \\
\hline sem9 & | &,- 0910797 &, 0542287 & $-1,68$ & 0,093 &,- 197366 &, 0152066 \\
\hline _cons & I &,- 6264767 &, 1731459 & $-3,62$ & 0,000 &,- 9658364 &,- 287117 \\
\hline sigma_u & | &, 11095558 & & & & & \\
\hline sigma_e & | &, 23858462 & & & & & \\
\hline rho & | &, 17781989 & (fraction & f varia & ce due & u_i) & \\
\hline
\end{tabular}


- xtreg roe ln_pl alavanc alavanc2 sem1-sem9 if tipo==4\&filtro==1, re vce(robust)

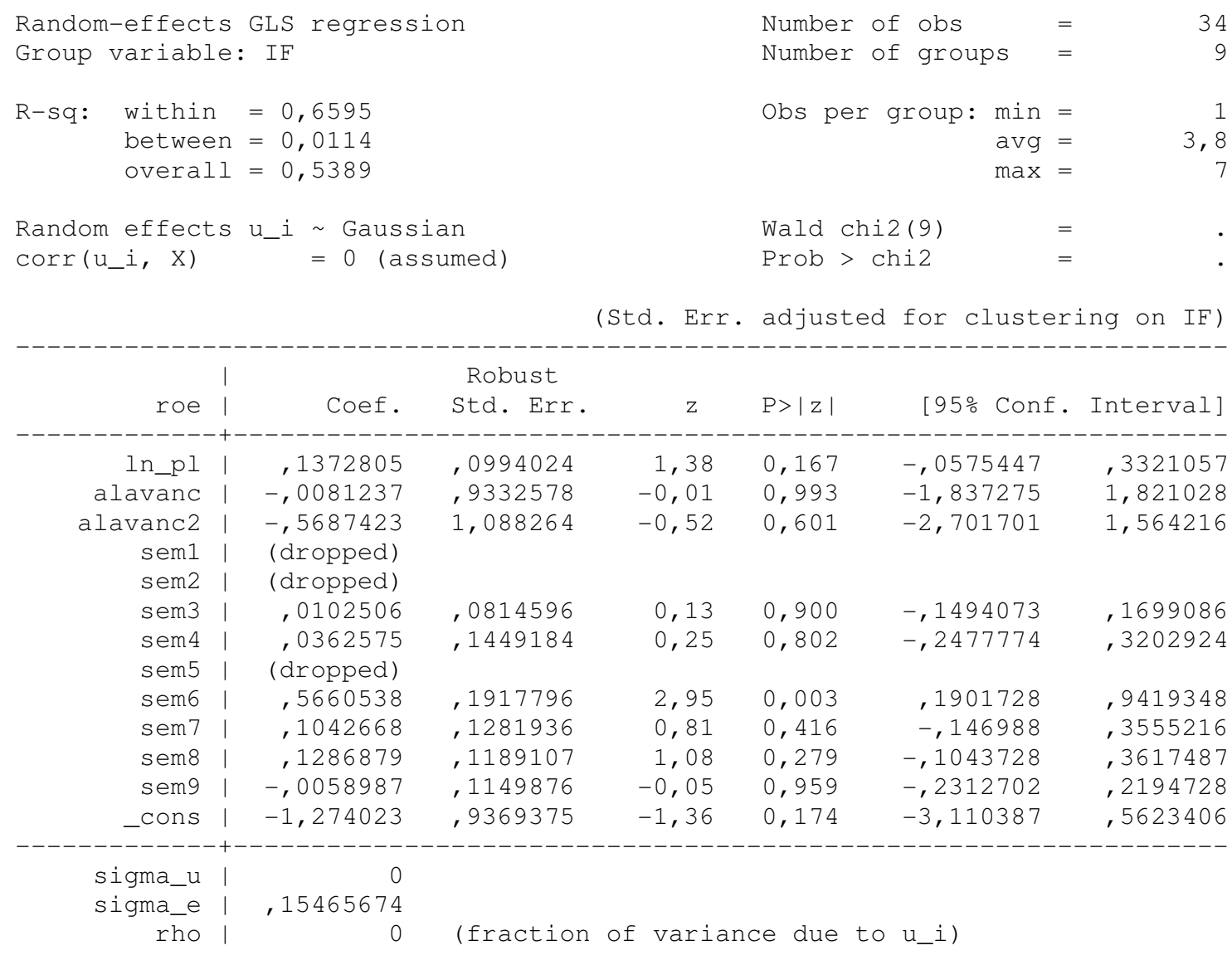


- reg roe ln_pl sem1-sem9 if tipo==1\&filtro==1, vce(robust)

Linear regression

$\begin{array}{llr}\text { Number of obs } & = & 895 \\ \text { F }(10,884) & = & 14,73 \\ \text { Prob }>\text { F } & = & 0,0000 \\ \text { R-squared } & =0,1428 \\ \text { Root MSE } & =, 17087\end{array}$

\begin{tabular}{|c|c|c|c|c|c|c|c|}
\hline & | & & Robust & & & & \\
\hline roe & | & Coef. & Std. Err. & t & $P>|t|$ & [95\% Conf. & Interval] \\
\hline ln_pl & | &, 0312164 &, 0029049 & 10,75 & 0,000 &, 025515 &, 0369177 \\
\hline sem 1 & | &, 0766605 &, 0258334 & 2,97 & 0,003 &, 0259585 &, 1273625 \\
\hline sem2 & | &, 066488 &, 0274684 & 2,42 & 0,016 &, 0125772 &, 1203988 \\
\hline sem3 & | &, 054248 &, 0256797 & 2,11 & 0,035 &, 0038477 &, 1046483 \\
\hline sem 4 & | &, 0346878 &, 0259171 & 1,34 & 0,181 &,- 0161784 &, 0855539 \\
\hline sem5 & | &, 0088956 &, 0242177 & 0,37 & 0,713 &,- 0386352 &, 0564264 \\
\hline sem6 & 1 &, 009305 &, 0244115 & 0,38 & 0,703 &,- 0386062 &, 0572163 \\
\hline sem 7 & | &,- 0105638 &, 0251821 & $-0,42$ & 0,675 &,- 0599874 &, 0388599 \\
\hline sem 8 & | &,- 0213013 &, 0253283 & $-0,84$ & 0,401 &,- 0710118 &, 0284092 \\
\hline sem 9 & | &,- 0094902 &, 0239249 & $-0,40$ & 0,692 &,- 0564464 &, 0374659 \\
\hline _cons & I &,- 3634619 &, 0449976 & $-8,08$ & 0,000 &,- 4517765 &,- 2751473 \\
\hline
\end{tabular}

- reg roe ln_pl sem1-sem9 if tipo==2\&filtro==1, vce(robust)

Linear regression

$\begin{array}{lrr}\text { Number of obs } & = & 307 \\ \text { F (10, 296) } & 4,24 \\ \text { Prob }>\text { F } & =0,0000 \\ \text { R-squared } & =0,1052 \\ \text { Root MSE } & =, 15474\end{array}$

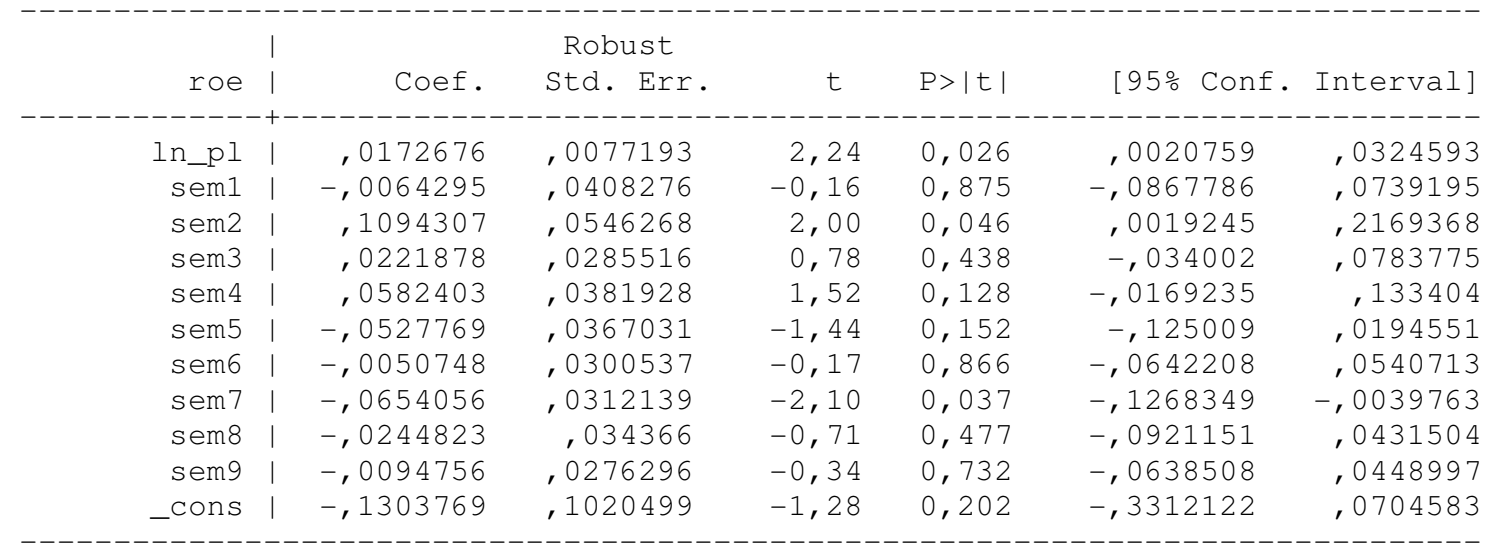


- reg roe ln_pl sem1-sem9 if tipo==3\&filtro==1, vce(robust)

Linear regression

$\begin{array}{llr}\text { Number of obs } & = & 281 \\ \text { F 8, 272) } & = & 9,10 \\ \text { Prob }>\text { F } & = & 0,0000 \\ \text { R-squared } & = & 0,1481 \\ \text { Root MSE } & = & , 27181\end{array}$

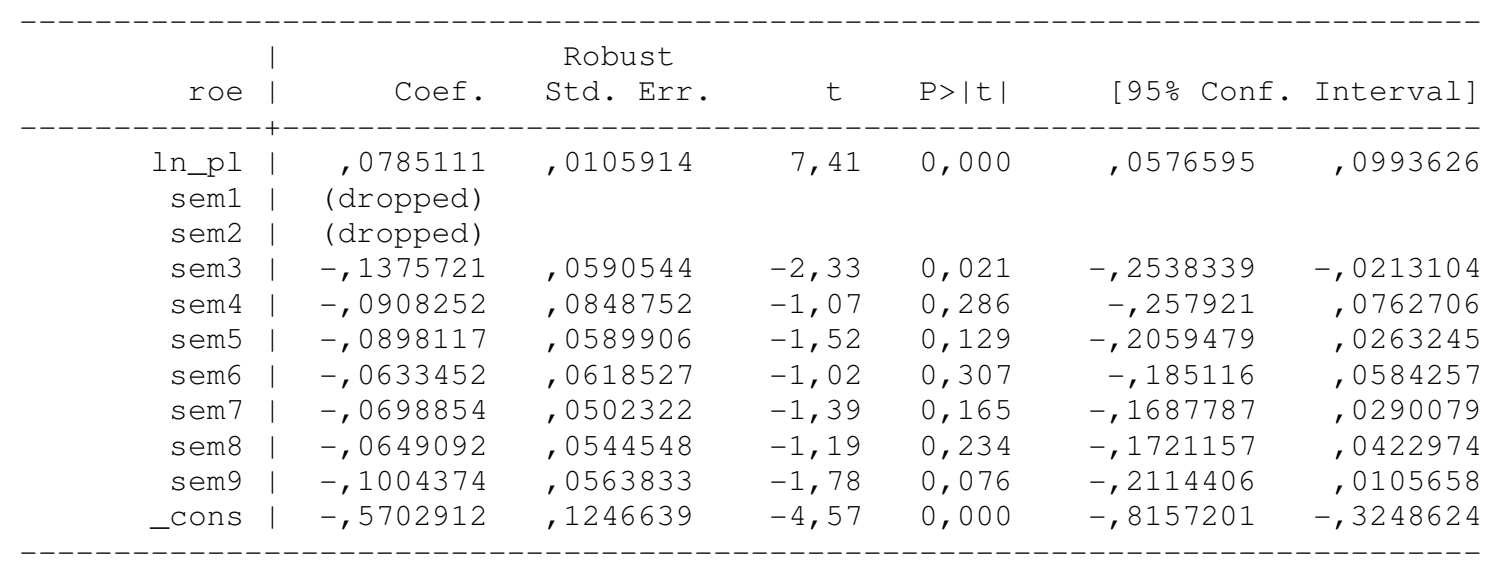

- reg roe ln_pl sem1-sem9 if tipo==4\&filtro==1, vce(robust)

Linear regression

$\begin{array}{lrr}\text { Number of obs } & = \\ \text { F 8, 71) } & 80 \\ \text { Prob }>\text { F } & =0,1991 \\ \text { R-squared } & =0,1906 \\ \text { Root MSE } & =, 27071\end{array}$

\begin{tabular}{|c|c|c|c|c|c|c|c|}
\hline roe & 1 & Coef. & $\begin{array}{l}\text { Robust } \\
\text { Std. Err. }\end{array}$ & t & $P>|t|$ & [95\% Conf. & Interval] \\
\hline $\begin{array}{l}\text { ln_pl } \\
\text { sem1 } \\
\text { sem2 }\end{array}$ & $\begin{array}{l}1 \\
\vdots \\
1\end{array}$ & $\begin{array}{l}, 0270606 \\
\text { (dropped) } \\
\text { (dropped) }\end{array}$ &, 052174 & 0,52 & 0,606 &,- 0769713 &, 1310925 \\
\hline sem3 & | &, 1849981 &, 1322281 & 1,40 & 0,166 &,- 0786572 &, 4486534 \\
\hline sem 4 & | &, 1260294 &, 1160803 & 1,09 & 0,281 &,- 1054282 &, 3574869 \\
\hline sem5 & | &, 0208957 &, 1322765 & 0,16 & 0,875 &,- 2428562 &, 2846476 \\
\hline sem6 & | &, 4230906 &, 2330406 & 1,82 & 0,074 &,- 0415792 &, 8877603 \\
\hline sem 7 & | &, 0918811 &, 1211332 & 0,76 & 0,451 &,- 1496517 &, 3334139 \\
\hline sem 8 & | &, 1030675 &, 1168094 & 0,88 & 0,381 &,- 1298439 &, 3359788 \\
\hline sem9 & | &, 0260785 &, 1202792 & 0,22 & 0,829 &,- 2137515 &, 2659085 \\
\hline _cons & । &,- 324084 &, 5655348 & $-0,57$ & 0,568 & $-1,451728$ &, 8035603 \\
\hline
\end{tabular}


- xtreg roe ln_pl seml-sem9 if tipo==1\&filtro==1, fe vce(robust)

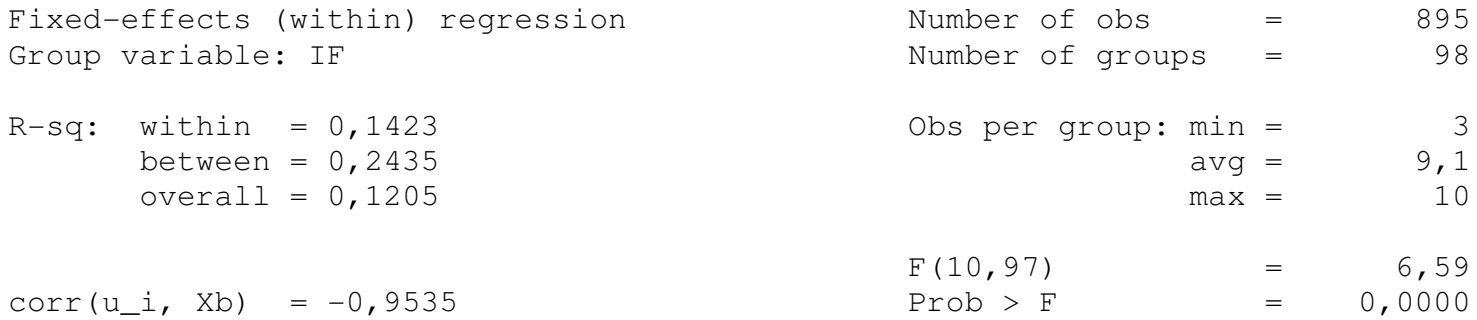

(Std. Err. adjusted for 98 clusters in IF)

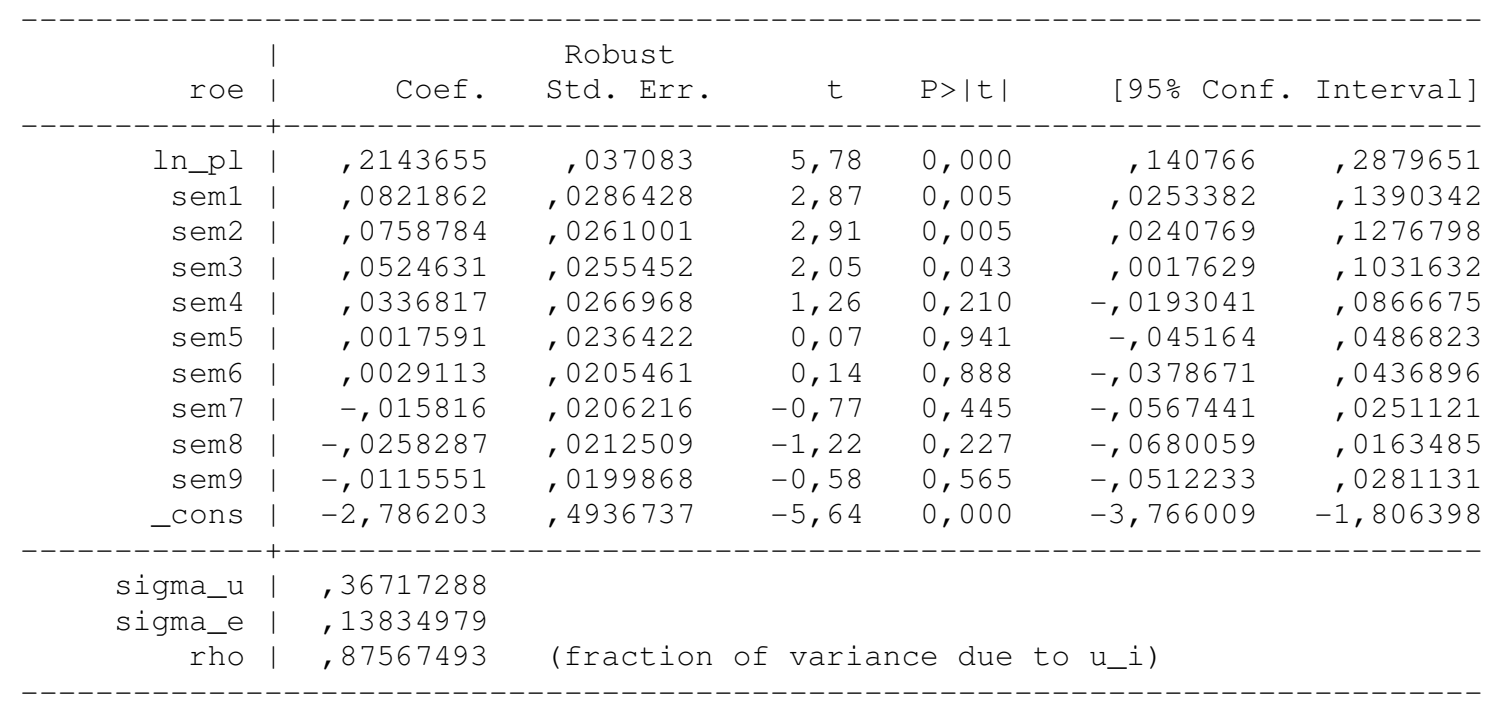

- xtreg roe ln_pl seml-sem9 if tipo==2\&filtro==1, fe vce(robust)

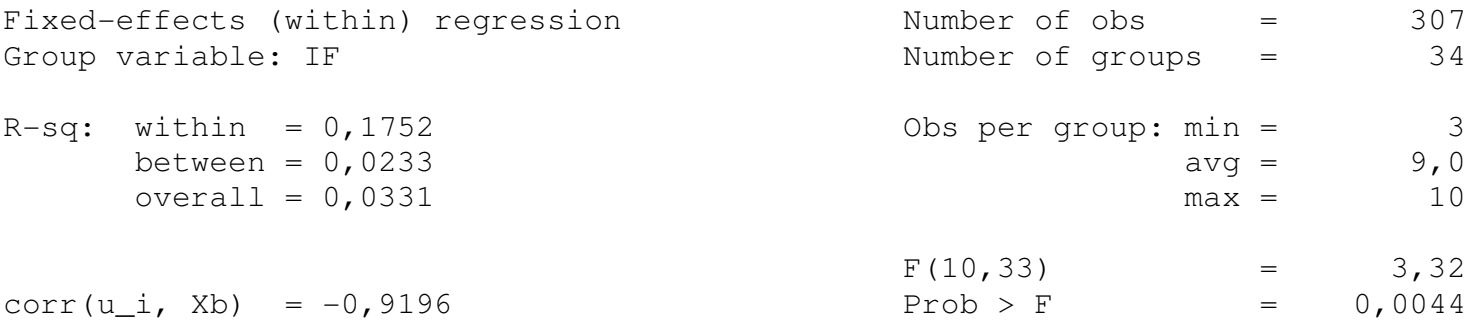

(Std. Err. adjusted for 34 clusters in IF)

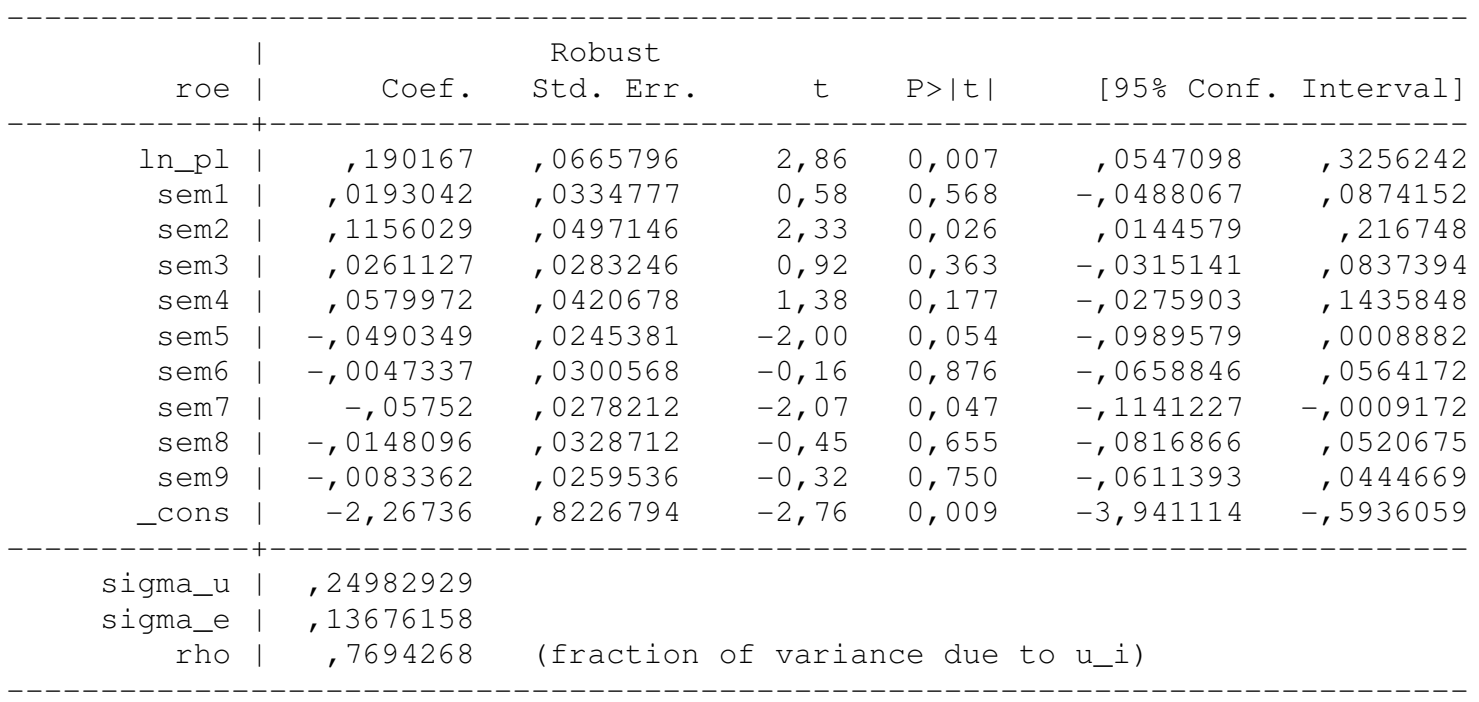


- xtreg roe ln_pl seml-sem9 if tipo==3\&filtro==1, fe vce(robust)

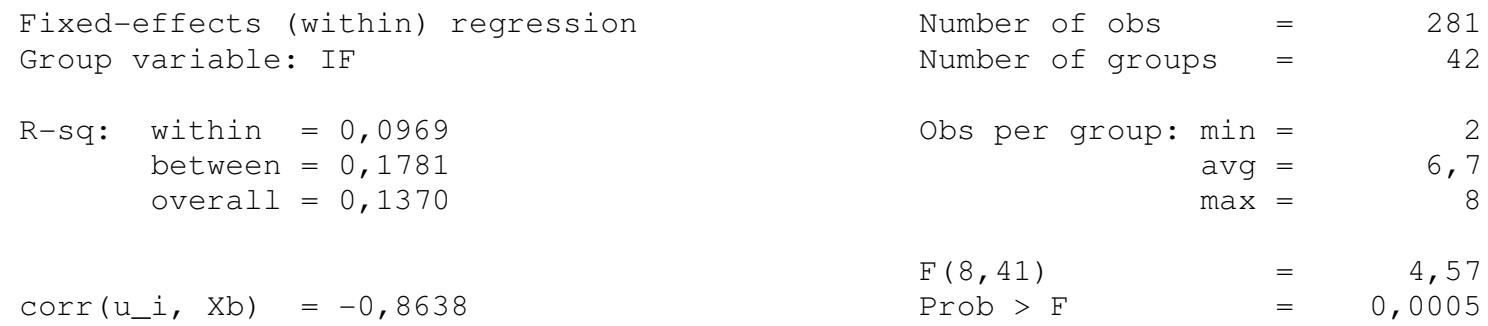

(Std. Err. adjusted for 42 clusters in IF)

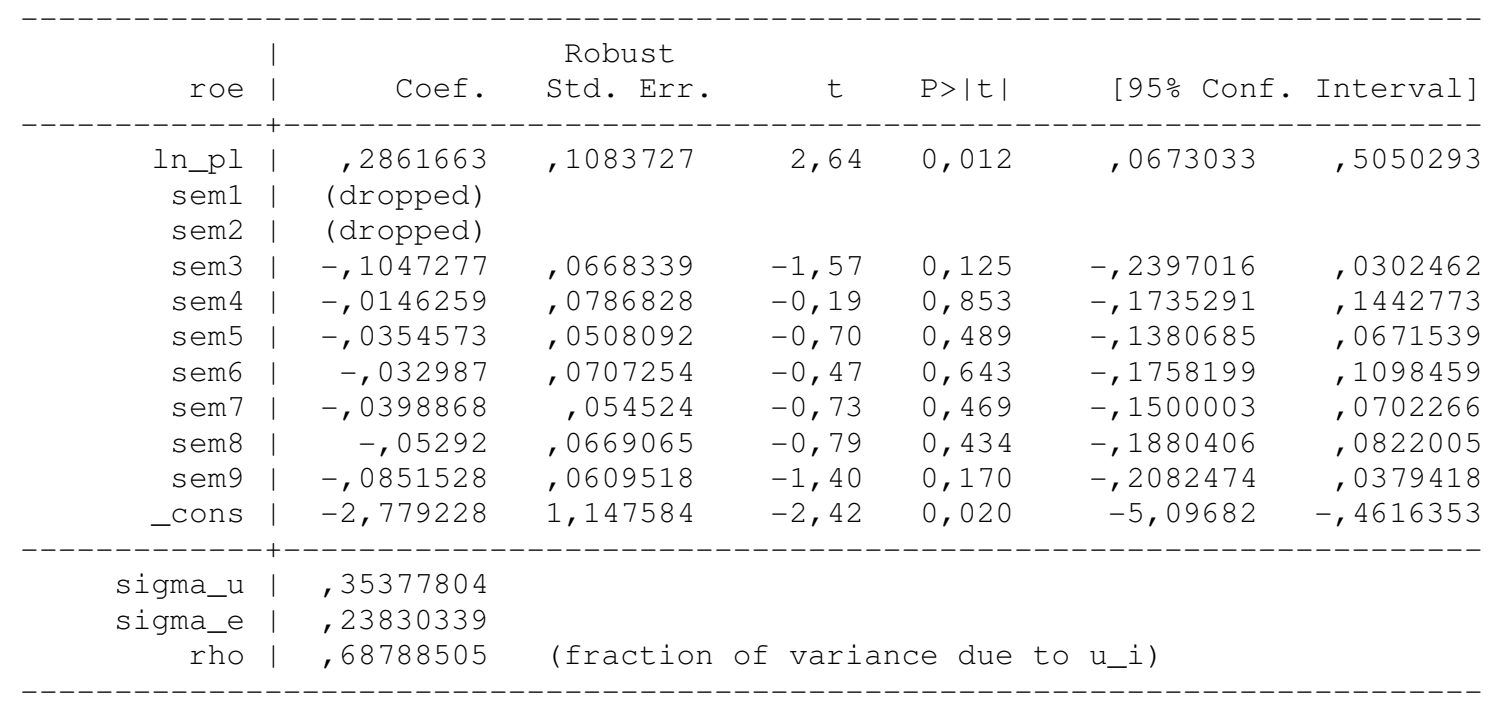

- xtreg roe ln_pl seml-sem9 if tipo==4\&filtro==1, fe vce(robust)

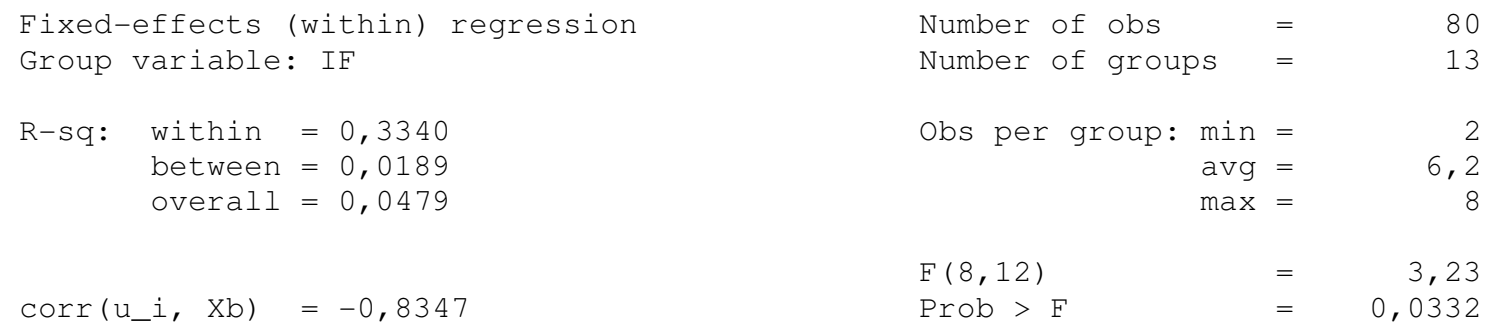

(Std. Err. adjusted for 13 clusters in IF)

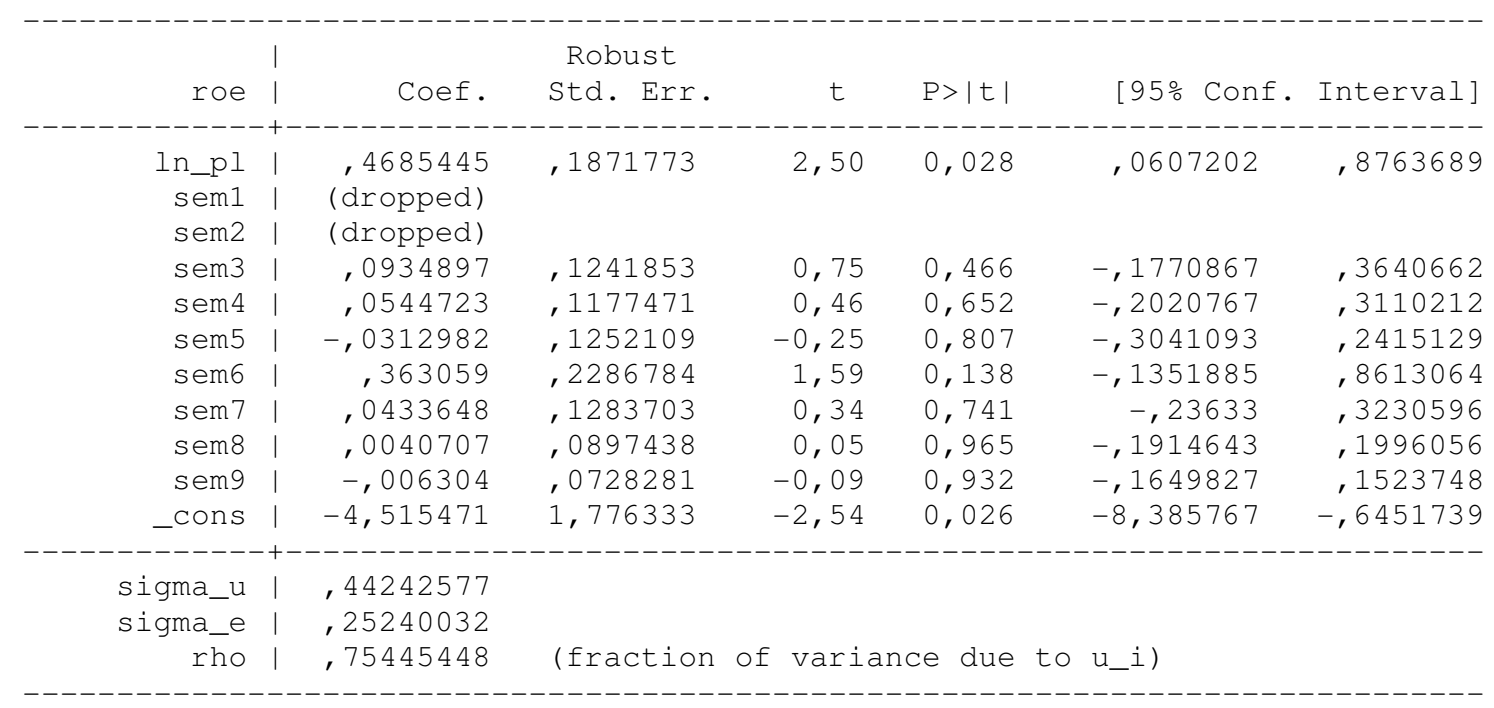


- xtreg roe ln_pl seml-sem9 if tipo==1\&filtro==1, re vce(robust)

Random-effects GLS regression Group variable: IF

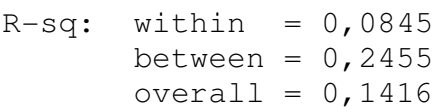

Number of obs $\quad=\quad 895$

Number of groups $=98$

Obs per group: $\min =3$

$\operatorname{avg}=\quad 9,1$

$\max =10$

Wald chi2 (10) $=77,25$

Prob $>$ chi2 $=0,0000$

(Std. Err. adjusted for clustering on IF)

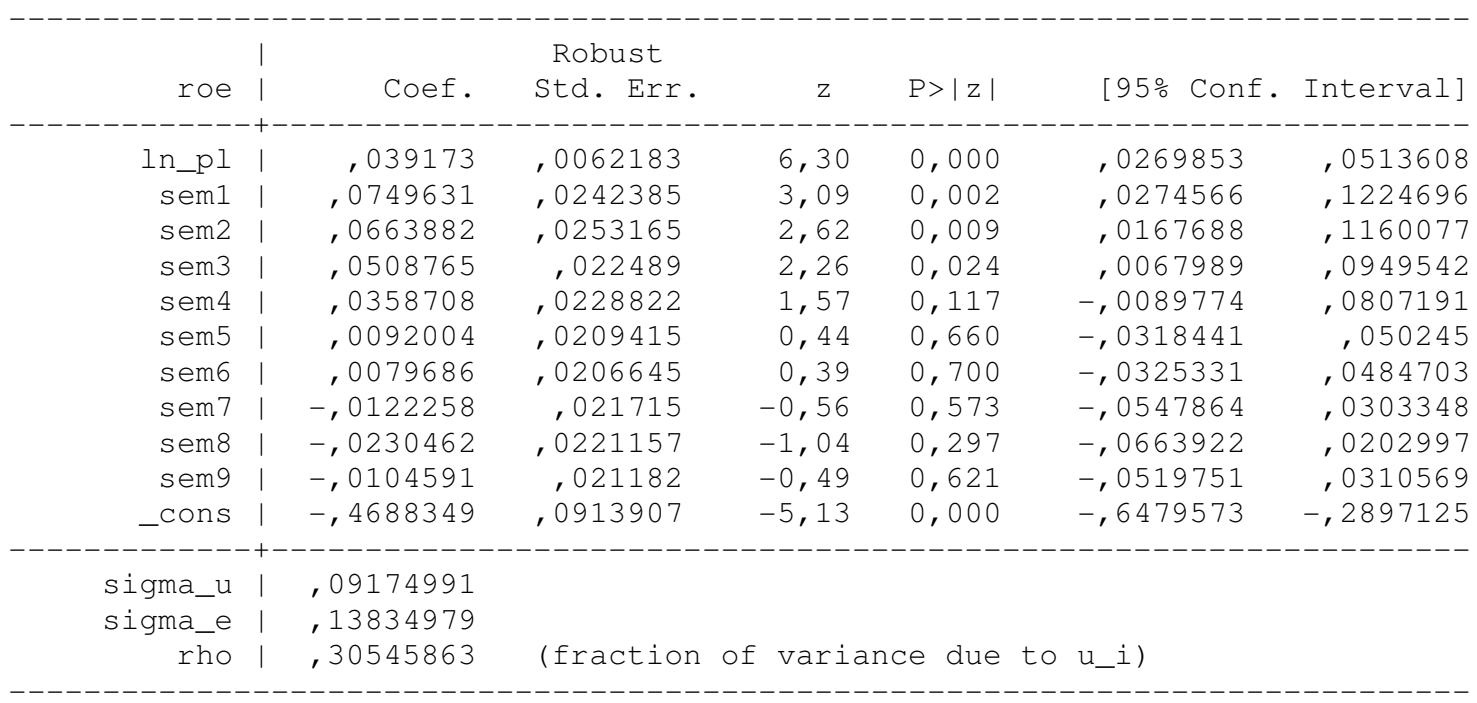

- xtreg roe ln_pl seml-sem9 if tipo==2\&filtro==1, re vce(robust)

Random-effects GLS regression

Group variable: IF

$$
\begin{aligned}
\text { R-sq: } & \text { within }=0,1090 \\
\text { between } & =0,1030 \\
\text { overall } & =0,1040
\end{aligned}
$$

Random effects u_i Gaussian

$\operatorname{corr}\left(u_{-}, \mathrm{X}\right) \quad=0$ (assumed)
Number of obs $\quad=\quad 307$

Number of groups $=34$

Obs per group: $\min =$

$\operatorname{avg}=\quad 9,0$

$\max =10$

Wald $\operatorname{chi2}(10)=42,35$

Prob $>$ chi2 $=0,0000$

(Std. Err. adjusted for clustering on IF)

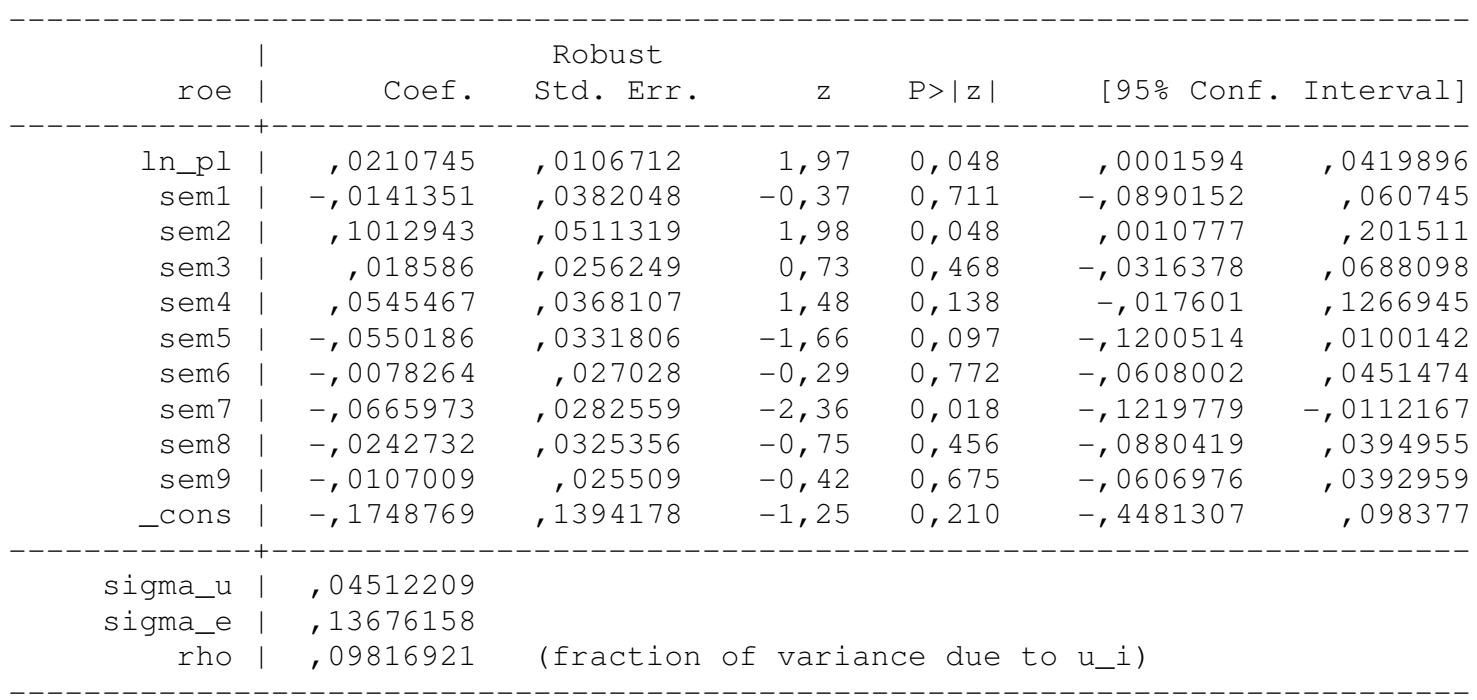


- xtreg roe ln_pl seml-sem9 if tipo==3\&filtro==1, re vce(robust)

Random-effects GLS regression Group variable: IF

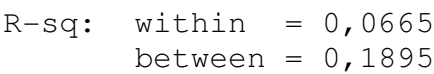
overall $=0,1479$

Random effects u_i Gaussian $\operatorname{corr}\left(u_{i} i, X\right)=0$ (assumed)
Number of obs $=281$

Number of groups $=42$

Obs per group: $\min =2$

$\operatorname{avg}=6,7$

$\max =8$

Wald chi2( 8 )

Prob > chi2

(Std. Err. adjusted for clustering on IF)

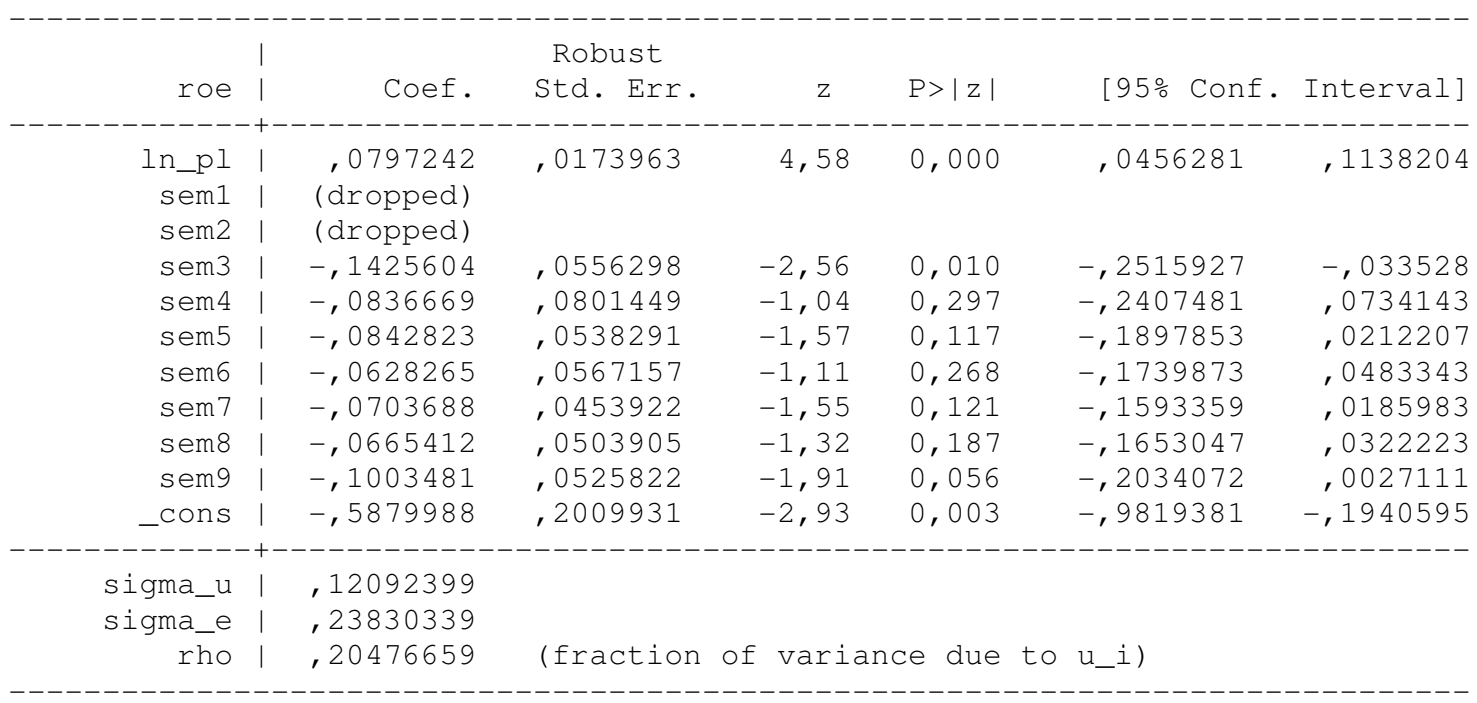

- xtreg roe ln_pl seml-sem9 if tipo==4\&filtro==1, re vce(robust)

Random-effects GLS regression

Group variable: IF
Number of obs=

Number of groups=

$\min =2$

$\operatorname{avg}=6,2$

between $=0,0471$

$\max =$

Wald chi2(8)

Prob $>$ chi2
Random effects u_i $\sim$ Gaussian
$\operatorname{corr}\left(u_{-}, \mathrm{X}\right)$

(Std. Err. adjusted for clustering on IF)

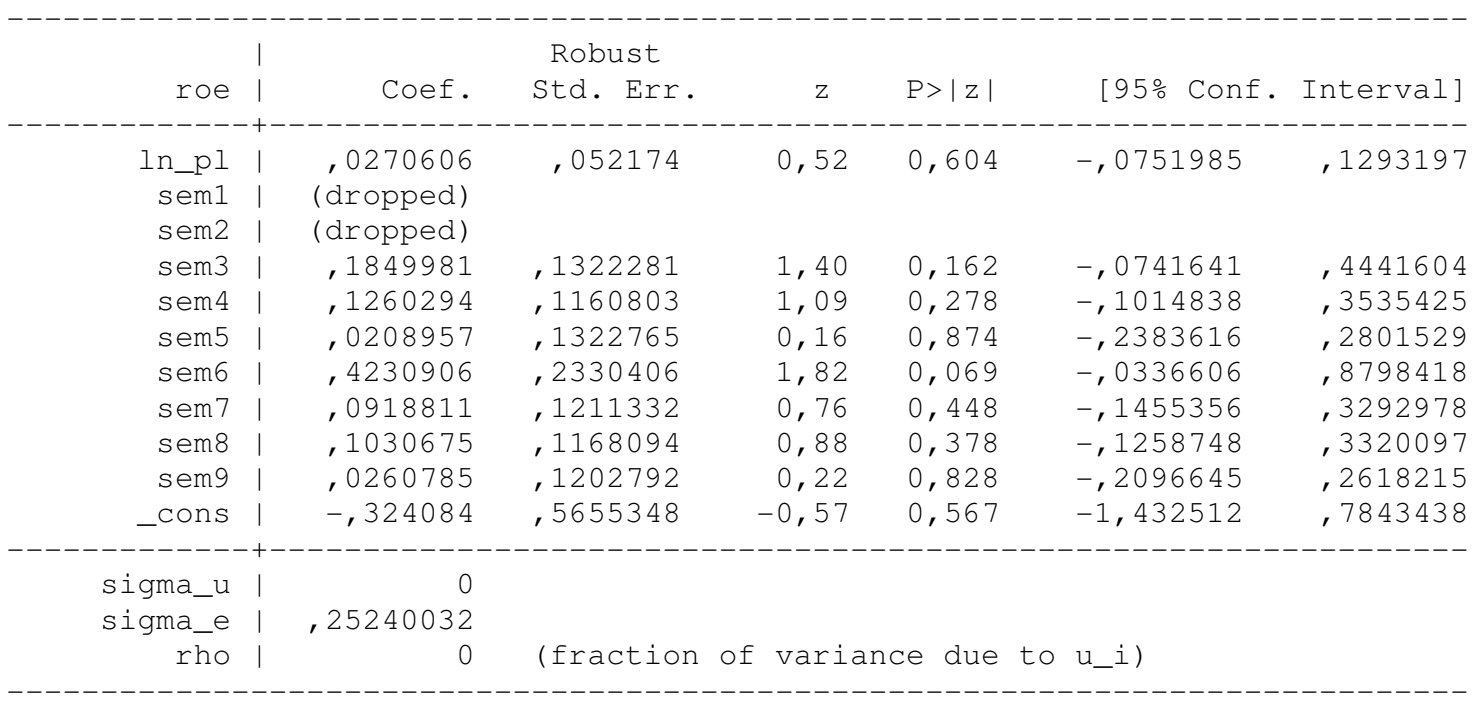


- quietly xtreg roe ln_pl alavanc alavanc2 seml-sem9 if tipo==1\&filtro==1, re v $>$ ce(robust)

xttesto

Breusch and Pagan Lagrangian multiplier test for random effects roe $[I F, t]=X b+u[I F]+e[I F, t]$

Estimated results:

\begin{tabular}{r|cc} 
& Var & sd $=\operatorname{sqrt}($ Var $)$ \\
roe &, 0336787 &, 1835175 \\
e &, 0184277 &, 1357486 \\
u &, 0079295 &, 0890479
\end{tabular}

Test: $\quad \operatorname{Var}(\mathrm{u})=0$

$\begin{array}{rrr}\text { Chi2 }(1) & = & 344,74 \\ \text { Prob }>\text { chi2 } & = & 0,0000\end{array}$

. xtoverid

Test of overidentifying restrictions: fixed vs random effects

Cross-section time-series model: xtreg re robust

Sargan-Hansen statistic 24,499 Chi-sq(12) P-value = 0,0174

- quietly xtreg roe ln_pl alavanc alavanc2 seml-sem9 if tipo==2\&filtro==1, re v $>$ ce(robust)

- xttest0

Breusch and Pagan Lagrangian multiplier test for random effects

roe $[I F, t]=X b+u[I F]+e[I F, t]$

Estimated results:

\begin{tabular}{r|cc} 
& Var & sd $=\operatorname{sqrt}(\operatorname{Var})$ \\
roe &, 0258869 &, 1608942 \\
e &, 0187246 &, 1368377 \\
u &, 0016606 &, 0407505
\end{tabular}

Test: $\quad \operatorname{var}(u)=0$

$$
\operatorname{chi2}(1)=22,49
$$

Prob $>$ chi2 $=0,0000$

xtoverid

Test of overidentifying restrictions: fixed vs random effects

Cross-section time-series model: xtreg re robust

Sargan-Hansen statistic 28,185 Chi-sq(10) $\quad$ P-value $=0,0017$ 
- quietly xtreg roe ln_pl alavanc alavanc2 seml-sem9 if tipo==3\&filtro==1, re $v$ $>$ ce(robust)

xttesto

Breusch and Pagan Lagrangian multiplier test for random effects roe $[I F, t]=X b+u[I F]+e[I F, t]$

Estimated results:

\begin{tabular}{r|cc} 
& Var & sd $=$ sqrt $($ Var $)$ \\
roe &, 085225 &, 2919331 \\
e &, 0569226 &, 2385846 \\
u &, 0123111 &, 1109556
\end{tabular}

Test: $\quad \operatorname{Var}(\mathrm{u})=0$

$\begin{aligned} \operatorname{chi}(1)= & 22,17 \\ \text { Prob }>\text { chi2 }= & 0,0000\end{aligned}$

. xtoverid

Test of overidentifying restrictions: fixed vs random effects

Cross-section time-series model: xtreg re robust

Sargan-Hansen statistic 16,269 Chi-sq(8) P-value $=0,0387$

- quietly xtreg roe ln_pl alavanc alavanc2 seml-sem9 if tipo==4\&filtro==1, re v $>$ ce(robust)

xttesto

Breusch and Pagan Lagrangian multiplier test for random effects

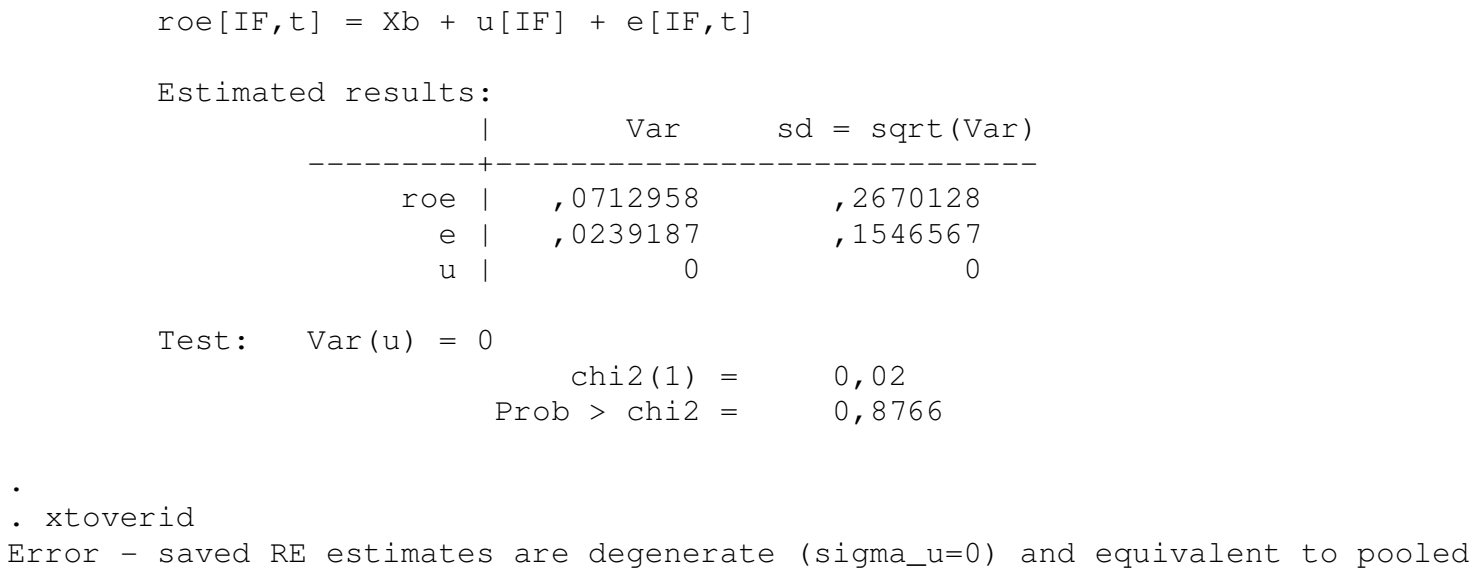

\begin{tabular}{r|rr} 
& Var & sd $=\operatorname{sqrt}(\operatorname{Var})$ \\
roe &, 0712958 &, 2670128 \\
$e$ &, 0239187 &, 1546567 \\
u & 0 & 0
\end{tabular}


- quietly xtreg roe ln_pl seml-sem9 if tipo==1\&filtro==1, re vce(robust)

- xttesto

Breusch and Pagan Lagrangian multiplier test for random effects

$$
\begin{aligned}
& \text { roe }[I F, t]=X b+u[I F]+e[I F, t] \\
& \operatorname{chi2}(1)=354,70
\end{aligned}
$$

\begin{tabular}{r|cc} 
& Var & sd $=$ sqrt $(\operatorname{Var})$ \\
roe &, 0336787 &, 1835175 \\
$e$ &, 0191407 &, 1383498 \\
u &, 008418 &, 0917499
\end{tabular}

Prob $>$ chi2 $=0,0000$

- xtoverid

Test of overidentifying restrictions: fixed vs random effects

Cross-section time-series model: xtreg re robust

Sargan-Hansen statistic 27,164 Chi-sq(10) P-value $=0,0025$

\begin{tabular}{|c|c|c|c|}
\hline Estim & ed results: & Var & $\operatorname{sd}=\operatorname{sqrt}(\operatorname{Var})$ \\
\hline & \begin{tabular}{r|r} 
roe & \\
$e$ & \\
$u$ &
\end{tabular} & $\begin{array}{r}, 0258869 \\
, 0187037 \\
, 002036\end{array}$ & $\begin{array}{l}, 1608942 \\
, 1367616 \\
, 0451221\end{array}$ \\
\hline Test: & $\operatorname{Var}(\mathrm{u})=\mathrm{c}$ & $\begin{array}{r}\operatorname{chi2}(1)= \\
\mathrm{b}>\operatorname{chi} 2=\end{array}$ & $\begin{array}{l}24,78 \\
0,0000\end{array}$ \\
\hline
\end{tabular}

- quietly xtreg roe ln_pl seml-sem9 if tipo==2\&filtro==1, re vce(robust)

xttest0

Breusch and Pagan Lagrangian multiplier test for random effects

. xtoverid

Test of overidentifying restrictions: fixed vs random effects

Cross-section time-series model: xtreg re robust

Sargan-Hansen statistic 26,460 Chi-sq(8) P-value $=0,0009$ 
- quietly xtreg roe ln_pl seml-sem9 if tipo==3\&filtro==1, re vce(robust)

- xttesto

Breusch and Pagan Lagrangian multiplier test for random effects

$$
\begin{array}{rc}
\text { roe }[\mathrm{IF}, \mathrm{t}]=\mathrm{Xb}+\mathrm{u}[\mathrm{IF}]+\mathrm{e}[\mathrm{IF}, \mathrm{t}] \\
\text { Estimated results: } & \mathrm{Var} \\
\mathrm{roe} & , 0842449 \\
\mathrm{e} & , 0567885 \\
\mathrm{u} & , 0146226 \\
\text { Test: } \operatorname{Var}(\mathrm{u})= &
\end{array}
$$

\begin{tabular}{r|cc} 
& Var & sd $=\operatorname{sqrt}(\operatorname{Var})$ \\
roe &, 0842449 &, 2902498 \\
e &, 0567885 &, 2383034 \\
u &, 0146226 &, 120924
\end{tabular}

$\begin{array}{rr}\operatorname{chi2}(1)= & 35,41 \\ \text { Prob }>\text { chi2 }= & 0,0000\end{array}$

- xtoverid

Test of overidentifying restrictions: fixed vs random effects

Cross-section time-series model: xtreg re robust

Sargan-Hansen statistic 23,311 Chi-sq(7) P-value $=0,0015$

- quietly xtreg roe ln_pl seml-sem9 if tipo==4\&filtro==1, re vce(robust)

\begin{tabular}{|c|c|c|}
\hline Estimated results & Var & sd $=\operatorname{sqrt}(\operatorname{Var}$ \\
\hline $\begin{array}{r}\text { roe } \\
e\end{array}$ & $\begin{array}{l}.0813738 \\
.0637059\end{array}$ &, 2852609 \\
\hline$u$ & 0 & 0 \\
\hline
\end{tabular}

- xttest0

Breusch and Pagan Lagrangian multiplier test for random effects

Test: $\quad \operatorname{Var}(\mathrm{u})=0$

$\begin{aligned} \operatorname{chi}(1)= & 0,00 \\ \text { Prob }>\text { chi2 }= & 0,9780\end{aligned}$

- xtoverid

Error - saved RE estimates are degenerate (sigma_u=0) and equivalent to pooled $>$ OLS

$r(198)$;

$\cdot$

- log close

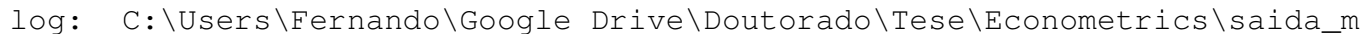

$>$ acro.smcl

log type: smcl

closed on: 29 Jan 2016, 01:59:21 


\section{APÊNDICE 8 - Teste da média condicional zero dos resíduos}

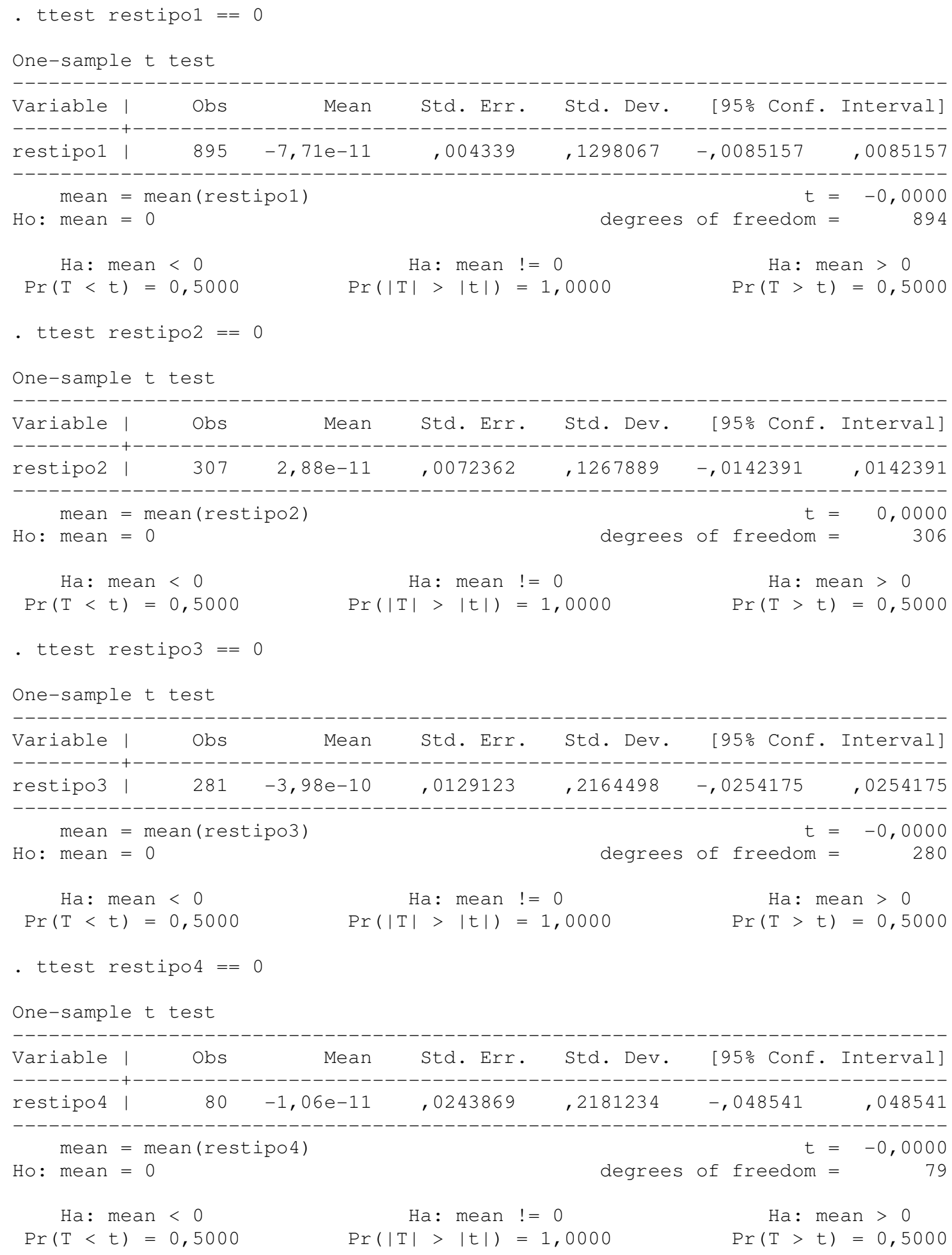


APÊNDICE 9 - Modelo de banco de dados para as regressões entre ROE e PL

\begin{tabular}{|c|c|c|c|c|c|c|c|c|c|c|c|c|c|c|c|c|}
\hline instituiçãa & tipologia & balancete & $l n \_p l$ & roe & alavanc & alavanc2 & sem1 & sem 2 & sem3 & sem4 & sem5 & sem6 & sem 7 & sem8 & sem 9 & sem10 \\
\hline A J RENNER & banco comercial & $06 / 2010$ & 11,3448 & 0,0827 & 0,4358 & 0,1899 & 1 & 0 & 0 & 0 & 0 & 0 & 0 & 0 & 0 & 0 \\
\hline A J RENNER & banco comercial & $12 / 2010$ & 11,3360 & 0,0868 & 0,4721 & 0,2229 & 0 & 1 & 0 & 0 & 0 & 0 & 0 & 0 & 0 & 0 \\
\hline A J RENNER & banco comercial & $06 / 2011$ & 11,3460 & 0,1041 & 0,5057 & 0,2558 & 0 & 0 & 1 & 0 & 0 & 0 & 0 & 0 & 0 & 0 \\
\hline A J RENNER & banco comercial & $12 / 2011$ & 11,3427 & 0,1242 & 0,5820 & 0,3387 & 0 & 0 & 0 & 1 & 0 & 0 & 0 & 0 & 0 & 0 \\
\hline A J RENNER & banco comercial & $06 / 2012$ & 11,3587 & 0,0918 & 0,6322 & 0,3997 & 0 & 0 & 0 & 0 & 1 & 0 & 0 & 0 & 0 & 0 \\
\hline A J RENNER & banco comercial & $12 / 2012$ & 11,3888 & 0,2527 & 0,6832 & 0,4668 & 0 & 0 & 0 & 0 & 0 & 1 & 0 & 0 & 0 & 0 \\
\hline A J RENNER & banco comercial & $06 / 2013$ & 11,4638 & 0,2362 & 0,6395 & 0,4090 & 0 & 0 & 0 & 0 & 0 & 0 & 1 & 0 & 0 & 0 \\
\hline A J RENNER & banco comercial & $12 / 2013$ & 11,4336 & 0,2508 & 0,7586 & 0,5755 & 0 & 0 & 0 & 0 & 0 & 0 & 0 & 1 & 0 & 0 \\
\hline A J RENNER & banco comercial & $06 / 2014$ & 11,4627 & 0,1410 & 0,8088 & 0,6542 & 0 & 0 & 0 & 0 & 0 & 0 & 0 & 0 & 1 & 0 \\
\hline A J RENNER & banco comercial & $12 / 2014$ & 11,5210 & 0,3269 & 0,7801 & 0,6086 & 0 & 0 & 0 & 0 & 0 & 0 & 0 & 0 & 0 & 1 \\
\hline ABC-BRASIL & banco comercial & $06 / 2010$ & 14,3279 & 0,1711 & 0,6222 & 0,3871 & 1 & 0 & 0 & 0 & 0 & 0 & 0 & 0 & 0 & 0 \\
\hline ABC-BRASIL & banco comercial & $12 / 2010$ & 14,3534 & 0,1763 & 0,6875 & 0,4727 & 0 & 1 & 0 & 0 & 0 & 0 & 0 & 0 & 0 & 0 \\
\hline ABC-BRASIL & banco comercial & $06 / 2011$ & 14,3705 & 0,1868 & 0,7175 & 0,5149 & 0 & 0 & 1 & 0 & 0 & 0 & 0 & 0 & 0 & 0 \\
\hline ABC-BRASIL & banco comercial & $12 / 2011$ & 14,3970 & 0,1800 & 0,7051 & 0,4972 & 0 & 0 & 0 & 1 & 0 & 0 & 0 & 0 & 0 & 0 \\
\hline ABC-BRASIL & banco comercial & $06 / 2012$ & 14,4172 & 0,1599 & 0,7746 & 0,6001 & 0 & 0 & 0 & 0 & 1 & 0 & 0 & 0 & 0 & 0 \\
\hline ABC-BRASIL & banco comercial & $12 / 2012$ & 14,4535 & 0,1520 & 0,6962 & 0,4847 & 0 & 0 & 0 & 0 & 0 & 1 & 0 & 0 & 0 & 0 \\
\hline ABC-BRASIL & banco comercial & $06 / 2013$ & 14,4886 & 0,1551 & 0,6790 & 0,4611 & 0 & 0 & 0 & 0 & 0 & 0 & 1 & 0 & 0 & 0 \\
\hline ABC-BRASIL & banco comercial & $12 / 2013$ & 14,5287 & 0,1683 & 0,7432 & 0,5524 & 0 & 0 & 0 & 0 & 0 & 0 & 0 & 1 & 0 & 0 \\
\hline ABC-BRASIL & banco comercial & $06 / 2014$ & 14,5496 & 0,1664 & 0,7857 & 0,6173 & 0 & 0 & 0 & 0 & 0 & 0 & 0 & 0 & 1 & 0 \\
\hline ABC-BRASIL & banco comercial & $12 / 2014$ & 14,5987 & 0,1642 & 0,7639 & 0,5835 & 0 & 0 & 0 & 0 & 0 & 0 & 0 & 0 & 0 & 1 \\
\hline AGIPLAN CFI & financeira & $06 / 2011$ & 8,8060 & 0,0891 & 0,6152 & 0,3785 & 0 & 0 & 1 & 0 & 0 & 0 & 0 & 0 & 0 & 0 \\
\hline AGIPLAN CFI & financeira & $12 / 2011$ & 9,7452 & 2,6595 & 0,5729 & 0,3282 & 0 & 0 & 0 & 1 & 0 & 0 & 0 & 0 & 0 & 0 \\
\hline AGIPLAN CFI & financeira & $06 / 2012$ & 10,4387 & 2,8186 & & & 0 & 0 & 0 & 0 & 1 & 0 & 0 & 0 & 0 & 0 \\
\hline AGIPLAN CFI & financeira & $12 / 2012$ & 10,8257 & 0,7542 & 0,3716 & 0,1381 & 0 & 0 & 0 & 0 & 0 & 1 & 0 & 0 & 0 & 0 \\
\hline AGIPLAN CFI & financeira & $06 / 2013$ & 11,0427 & 0,6423 & 0,3303 & 0,1091 & 0 & 0 & 0 & 0 & 0 & 0 & 1 & 0 & 0 & 0 \\
\hline AGIPLAN CFI & financeira & $12 / 2013$ & 11,2181 & 1,0634 & 0,3929 & 0,1543 & 0 & 0 & 0 & 0 & 0 & 0 & 0 & 1 & 0 & 0 \\
\hline AGIPLAN CFI & financeira & $06 / 2014$ & 11,5066 & 0,9399 & 0,3716 & 0,1381 & 0 & 0 & 0 & 0 & 0 & 0 & 0 & 0 & 1 & 0 \\
\hline$\bullet$ & $\bullet$ & $\bullet \bullet$ & $\bullet \bullet$ & $\bullet$ & $\bullet \bullet$ & $\bullet \bullet$ & $\bullet \bullet$ & $\bullet \bullet$ & $\bullet \bullet$ & $\bullet$ & $\bullet \bullet$ & $\bullet \bullet$ & $\bullet \bullet$ & $\bullet \bullet$ & $\bullet \bullet$ & $\bullet \bullet$ \\
\hline
\end{tabular}


APÊNDICE 10 - Modelo de banco de dados para a estimação do beta

\begin{tabular}{|c|c|c|c|c|}
\hline banco & mês & $\xi i, j$ & $\xi_{\text {IBOVESPA }}$ & $l n_{-} p l$ \\
\hline ITAU UNIBANCO ON & $01 / 2014$ & $-0,0393$ & $-0,0331$ & 18,2897 \\
\hline ALFA INV ON & $01 / 2014$ & $-0,0180$ & $-0,0331$ & 14,5405 \\
\hline AMAZONIA ON & $01 / 2014$ & $-0,0034$ & $-0,0331$ & 14,5752 \\
\hline ESTADO CEARÁ ON & $01 / 2014$ & & $-0,0331$ & 12,9757 \\
\hline PAN ON & $01 / 2014$ & & $-0,0331$ & 14,9073 \\
\hline BANESE ON & $01 / 2014$ & & $-0,0331$ & 12,5890 \\
\hline BANESTES ON & $01 / 2014$ & $-0,0398$ & $-0,0331$ & 13,5854 \\
\hline BANPARÁ ON & $01 / 2014$ & & $-0,0331$ & 12,9250 \\
\hline BANRISUL ON & $01 / 2014$ & $-0,0312$ & $-0,0331$ & 15,4343 \\
\hline BICBANCO ON & $01 / 2014$ & & $-0,0331$ & 14,5301 \\
\hline BRADESCO ON & $01 / 2014$ & $-0,0575$ & $-0,0331$ & 18,1130 \\
\hline BRASIL ON & $01 / 2014$ & $-0,0805$ & $-0,0331$ & 18,0039 \\
\hline BRB ON & $01 / 2014$ & & $-0,0331$ & 13,8745 \\
\hline BTG PACTUAL ON & $01 / 2014$ & & $-0,0331$ & 16,2261 \\
\hline DAYCOVAL ON & $01 / 2014$ & & $-0,0331$ & 14,7648 \\
\hline INDUSVAL ON & $01 / 2014$ & & $-0,0331$ & 13,1736 \\
\hline MERCANTIL BRASIL ON & $01 / 2014$ & $-0,0664$ & $-0,0331$ & 13,7456 \\
\hline PARANÁ ON & $01 / 2014$ & & $-0,0331$ & 14,0854 \\
\hline PINE ON & $01 / 2014$ & & $-0,0331$ & 14,1013 \\
\hline SANTANDER ON & $01 / 2014$ & $-0,0301$ & $-0,0331$ & 18,0266 \\
\hline SOFISA ON & $01 / 2014$ & & $-0,0331$ & 13,5241 \\
\hline ITAU UNIBANCO ON & $02 / 2014$ & 0,0401 & $-0,0367$ & 18,2842 \\
\hline ALFA INV ON & $02 / 2014$ & 0,0031 & $-0,0367$ & 14,5350 \\
\hline AMAZONIA ON & $02 / 2014$ & $-0,0385$ & $-0,0367$ & 14,5697 \\
\hline ESTADO CEARÁ ON & $02 / 2014$ & & $-0,0367$ & 12,9702 \\
\hline PAN ON & $02 / 2014$ & & $-0,0367$ & 14,9018 \\
\hline BANESE ON & $02 / 2014$ & & $-0,0367$ & 12,5835 \\
\hline BANESTES ON & $02 / 2014$ & $-0,0227$ & $-0,0367$ & 13,5799 \\
\hline BANPARÁ ON & $02 / 2014$ & & $-0,0367$ & 12,9196 \\
\hline BANRISUL ON & $02 / 2014$ & & $-0,0367$ & 15,4288 \\
\hline BICBANCO ON & $02 / 2014$ & & $-0,0367$ & 14,5246 \\
\hline BRADESCO ON & $02 / 2014$ & $-0,0292$ & $-0,0367$ & 18,1075 \\
\hline BRASIL ON & $02 / 2014$ & $-0,0778$ & $-0,0367$ & 17,9984 \\
\hline BRB ON & $02 / 2014$ & $-0,0030$ & $-0,0367$ & 13,8690 \\
\hline BTG PACTUAL ON & $02 / 2014$ & & $-0,0367$ & 16,2206 \\
\hline DAYCOVAL ON & $02 / 2014$ & & $-0,0367$ & 14,7593 \\
\hline INDUSVAL ON & $02 / 2014$ & & $-0,0367$ & 13,1681 \\
\hline MERCANTIL BRASIL ON & $02 / 2014$ & $-0,0157$ & $-0,0367$ & 13,7402 \\
\hline PARANÁ ON & $02 / 2014$ & & $-0,0367$ & 14,0799 \\
\hline PINE ON & $02 / 2014$ & & $-0,0367$ & 14,0958 \\
\hline SANTANDER ON & $02 / 2014$ & $-0,0667$ & $-0,0367$ & 18,0211 \\
\hline ... & •.• & •.• & •.• & •.• \\
\hline
\end{tabular}

